\title{
Economic and Social Transformation in China
}

The Center for China Studies is among China's most influential think-tanks, and its China Studies Reports are read at the highest levels of government. Now for the first time the most important of these reports is collected in book form in English, providing a fascinating insight into the challenges and opportunities for Chinese development and the government's thinking on economic and social issues. Including comparative studies with developed and developing nations, analysis of past economic performance and future trends, and effects of demographic shifts such as population aging and urbanization, this book is an essential collection of research and includes notes made by central party leaders. Compiled by the founder of the Center for China Studies, one of the country's leading economists, this book is key to understanding Chinese development and the likely future path of government policy. This book includes 48 figures and 84 tables.

Angang Hu is Professor at the School of Public Policy and Management of Tsinghua University, head of the Center for China Studies of Tsinghua University and the China Academy of Sciences. He has published over 50 books on public policy and China Studies, including China: New Conception of Development (2004). 


\section{Routledge Studies on the Chinese Economy}

\section{Series Editor}

Peter Nolan, University of Cambridge

Founding Series Editors

Peter Nolan, University of Cambridge and

Dong Fureng, Beijing University

The aim of this series is to publish original, high-quality, research-level work by both new and established scholars in the West and the East, on all aspects of the Chinese economy, including studies of business and economic history.

1 The Growth of Market

Relations in Post-reform

Rural China

A Micro-Analysis of Peasants,

Migrants and Peasant

Entrepreneurs

Hiroshi Sato

2 The Chinese Coal Industry:

An Economic History

Elspeth Thomson

3 Sustaining China's Economic

Growth in the Twenty-First

Century

Edited by Shujie Yao and

Xiaming Liu

4 China's Poor Regions: Ruralurban migration, poverty, economic reform and urbanisation

Mei Zhang

5 China's Large Enterprises and the Challenge of Late

Industrialization

Dylan Sutherland
6 China's Economic Growth Yanrui $W u$

7 The Employment Impact of China's World Trade Organisation Accession A.S. Bhalla and S. Qiu

8 Catch-Up and Competitiveness in China

The Case of Large Firms in the Oil Industry

Jin Zhang

9 Corporate Governance in China

Jian Chen

10 The Theory of the Firm and Chinese Enterprise Reform The Case of China International Trust and Investment Corporation Qin Xiao

11 Globalisation, Transition and Development in China The Case of the Coal Industry Huaichuan Rui 
12 China Along the Yellow River

Reflections on Rural Society Cao Jinqing, translated by

Nicky Harman and

Huang Ruhua

13 Economic Growth, Income

Distribution and Poverty

Reduction in Contemporary

China

Shujie Yao

14 China's Economic Relations with the West and Japan, 1949-79

Grain, Trade and Diplomacy

Chad J. Mitcham

15 China's Industrial Policy and the Global Business Revolution The Case of the Domestic Appliance Industry

Ling Liu

16 Managers and Mandarins in Contemporary China

The Building of an International Business Alliance

Jie Tang

17 The Chinese Model of Modern Development

Edited by Tian Yu Cao
18 Chinese Citizenship

Views from the Margins

Edited by Vanessa L. Fong and

Rachel Murphy

19 Unemployment, Inequality and Poverty in Urban

China

Edited by Shi Li and

Hiroshi Sato

20 Globalisation, Competition and Growth in China

Edited by Jian Chen and

Shujie Yao

21 The Chinese Communist Party in Reform

Edited by Kjeld Erik Brodsgaard and Zheng Yongnian

22 Poverty and Inequality among Chinese Minorites

A.S. Bhalla and Shufang Qiu

23 Economic and Social Transformation in China Challenges and Opportunities Hu Angang

24 Global Big Business and the Chinese Brewing Industry

Yuantao Gua 



\section{Economic and Social Transformation in China \\ Challenges and opportunities}

Angang Hu 
First published 2007 by Routledge

Published 2017 by Routledge

2 Park Square, Milton Park, Abingdon, Oxon OX14 4RN

711 Third Avenue, New York, NY 10017, USA

Routledge is an imprint of the Taylor \& Francis Group, an informa business

Copyright (C) 2007 Angang $\mathrm{Hu}$

Typeset in Times New Roman by

Keystroke, 28 High Street, Tettenhall, Wolverhampton

The Open Access version of this book, available at www.tandfebooks.com, has been made available under a Creative Commons Attribution-Non Commercial-No Derivatives 4.0 license.

British Library Cataloguing in Publication Data

A catalogue record for this book is available from the British Library

Library of Congress Cataloging in Publication Data

Economic and social transformation in China : challenges and opportunities / Angang Hu, [editor].

p. cm. - (Routledge studies on the Chinese economy)

Includes bibliographical references and index.

ISBN 0-415-38067-7 (hardback : alk. paper) 1. China-Economic

policy-21st century. 2. China-Social policy-21st century. I. Hu, Angang.

II. Title. III. Series

HC427.95.E34 2006

$330.951-\mathrm{dc} 22$

2005034794

ISBN13: 978-0-415-38067-6 (hbk) 


\section{Contents}

List of figures $\quad$ ix

List of tables $\quad$ xi

About the author $\quad \mathrm{xV}$

Acknowledgments xvii

Introduction 1

1 Why has China's economy grown so fast? 9

2 Comprehensive national power (1980-2000): a comparative study of the US, Russia, Japan, India and China 33

3 Why has China's TFP dropped in 1995-2001? 60

4 From unevenness to coordination for China's regional development (1978-2004) 67

5 China's economic growth and poverty reduction (1978-2002) 97

6 China's macro-economy and health 133

7 Health insecurity: the biggest challenge to human security in China

8 Developing human resources to cope with an aging society 167

9 China's urban unemployment and social security (1993-2000) 184

10 Genuine national savings and natural capital cost in China (1970-2001)

11 Corruption: an enormous black hole: public exposure of the economic costs of corruption 


\section{viii Contents}

12 Second transition of the Communist Party of China:

from economic development to institution building

13 Making policy decision-making more scientific, democratic, systematic and specialized

Notes

Index 


\section{List of figures}

1.1 Per capita GDP comparisons of major countries (1870-1998) 13

1.2 Changes of China's labor participation, institution, and knowledge indicators (1978-1998) 24

2.1 Percentage of comprehensive national power in world total (1980-2000)

3.1 TFP growth in different periods (1979-2001) 63

4.1 Relative regional disparities (per capita real GDP) since reform and opening up (1978-2002)

4.2 Breakdown of income disparities (1990-1999)

5.1 Percentage of employed persons in township and village enterprises, private enterprises and self-employed individuals in rural areas (1978-2001)

5.2 Percentage of wages income to total revenue (1985-2001) 103

5.3 Purchase price index of agricultural products (1985-2000) 105

5.4 Regional distribution of China's rural impoverished population (2000)

5.5 Multi-dimensional framework of poverty 112

5.6 Human poverty index (1998) 112

5.7 Proportion of illiterates and semiliterates above 15 years (1997) 113

5.8 Annual growth rate of GDP and consumption level per capita, urban and rural people (1978-2001) 114

5.9 Status of agriculture in the national economy (1978-2002) 115

5.10 Farmers' income and agricultural labor productivity (1978-2002) 116

5.11 Proportions of various income sources in farmers' per capita net income (1985-2000)

5.12 Status of employment since reform (1978-2001) 117

5.13 Ratio of per capita disposable income and per capita consumption expenditure of urban residents to those of rural residents (1978-2001)

5.14 Proportion of income from non-agricultural industries of rural residents (1986-1999)

6.1 Pregnant mortality rate trend (1989-2000) 140

6.2 Trend of mortality rate for children under 5 years old (1991-2000) 
7.1 Composition chart of health insecurity

8.1 Predicted proportion of population aged 65 and above and its growth rate (1980-2050)

8.2 Predicted proportion of population aged 15-64 and its growth rate (1980-2050)

8.3 Predicted old age dependency ratio and its growth rate (1980-2050)

8.4 Per capita GDP vs population aged 65+: China, Japan and the United States (1950-2000)

8.5 Percentage of pensions of retirees in GDP and ratio of on-the-job workers to retirees (1980-2003)

8.6 Return rate of education (1988-1999)

8.7 Income curve of age by level of education

8.8 Distribution of average level of education by age in urban and rural areas in 2000

8.9 China's birth rate (1949-1997)

8.10 Trend of changes in per capita human capital (1949-2000)

8.11 Proportion of laid-off workers in different age groups and their education experiences during the Cultural Revolution

9.1 Definitions of unemployment

9.2 Proportion of laid-off workers by sector (1999)

9.3 Coverage of basic living allowance for laid-off workers and relief for the registered unemployed (1995-2000)

9.4 Ratio of ordinary people who feel a high level of pressure in life

9.5 Employment trends for various sectors

9.6 Proportion of employment by sector (1950-2000) 205

$\begin{array}{lll}10.1 & \text { Energy depletion cost (1970-2000) } & 210\end{array}$

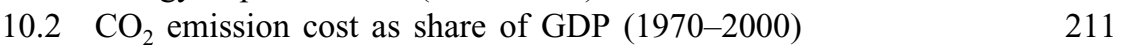

10.3 China's unit GDP $\mathrm{CO}_{2}$ emission (1960-2000) 212

10.4 Mineral resources depletion as share of GDP (1970-2000) 212

10.5 China's forest depletion as share of GDP (1978-2000) 213

$\begin{array}{lll}10.6 & \text { China's timber production (1978-2002) } & 214\end{array}$

10.7 China's natural capital cost as share of GDP (1970-2000) 214

10.8 Genuine domestic savings and net domestic savings rate (1970-2000) 


\section{List of tables}

1.1 Less advanced countries catch up with advanced ones 10

1.2 Per capita GDP comparisons among selected economies (1820-1998)

1.3 Percentage of GDP of major countries in the world total (1820-1998)

1.4 Four fastest developing economies during different periods of time in the world

1.5 Economic growth comparisons of five major countries (1980-2002)

1.6 Comparisons of economic indicators of five major countries (2002)

1.7 Percentage of industry value added, export trade of five major countries in the world total (1975-2002)

1.8 Sources of China per capita output growth (1978-1998) 17

1.9 China's economic structural changes (1952-2003) 20

1.10 Export competitiveness of China in world trade (1985-2000) 21

1.11 Evolution of the marketization development indicators (MDI) of the entire and local economic operational mechanism of China (1978-1999)

1.12 China's technology sources (1991-2001) 25

1.13 International comparison of the knowledge development indicator (KDI) (1980-2000)

2.1 Strategic resources and major indicators 41

2.2 Strategic resources and CNP of five countries (1980-2000) 42

2.3 Economic resources of China, US, India, Japan and Russia (1975-2000)

2.4 Five countries economic growth trend 47

2.5 Predicted long-term economic growth trend of five countries (1998-2020)

2.6 Human capital of five countries (1975-2000) 48

2.7 Natural resources of five countries (1975-2000) 49

2.8 Capital resources of five countries (1975-2000) 51

2.9 Knowledge and technology resources of five countries (1980-2000) 
2.10 Governmental resources of five countries (1975-2000) 53

2.11 Military resources of five countries (1985-2000) 54

2.12 International resources of five countries (1980-2000) 56

3.1 Estimates of China's economic growth sources (1952-2003) 62

3.2 TFP growth and its components during different periods of economic reform in China (1979-2001) 63

3.3 Poverty indicators and Gini coefficient (1985-2001) 65

3.4 Indicators for gauging poverty and changes in Gini coefficient (1985-2001) 65

4.1 Per capita incomes and distribution in China (1999) 69

4.2 Comparisons among different provinces, municipalities and autonomous regions in terms of human development (1999)

4.3 Human risk indices of regions in eastern, western and central China (1999)

4.4 Geographical distribution of low-income population living in rural and urban areas in China

4.5 Healthcare service accessibility indices for different regions in eastern, central and western China (1999)

4.6 Coefficients of relative variations for different regions in terms of major economic and social development indicators (1978-1999)

4.7 Regional disparities in terms of comprehensive knowledge capabilities: ranking by knowledge development indicator (KDI) (1998)

4.8 Regional disparities from a multi-dimensional perspective

4.9 Ranking of all provinces: the changing trend (1980-2002)

4.10 Policies of regional development (1953-present)

5.1 Annual rural poverty reduction, the growth rate of per capita GDP and farmers' consumption level (1978-2002)

5.2 The impoverished population in rural China and the rate of poverty (1978-2002)

5.3 Number of people living on less than $\$ 1$ per day, estimated by World Bank (1990-2015)

5.4 Percentage of the impoverished population in several Asian countries

5.5 Impoverished population and the poverty rate of the world (1950-1999)

5.6 Percentage of rural households grouped by per capita annual net income (1978-2001)

5.7 Population and rural-urban labor force migration (1982-2000) 103

$\begin{array}{lll}5.8 & \text { Basic status of China's human capital (1982-2003) } & 104\end{array}$

5.9 National poverty relief fund and the ratio in GDP (1986-2000) 105

5.10 China's official poverty line and its relative level (1978-2002) 107

5.11 Ranking of comprehensive knowledge developing index of different regions (1998) 
5.12 Volume of national agricultural products trade and the loss caused by price decreases (1996-2000)

5.13 Income and transferred income per capita of urban households and rural households (1985-2003)

5.14 Gini indices of income inequality in China (1980-2002)

5.15 National urban and rural poverty incidence rate and poverty population (1980-2002)

5.16 Income inequality and income growth rate (1981-2001) 123

5.17 Tax proportion of farmers by different income groups (1999) 124

5.18 To achieve millennium development goals (1990-2015) 126

5.19 Policy evolution of employment and transference of rural labor force (1984-2003)

6.1 Main indicators of human capital in China (1950-2000)

6.2 Average annual growth rate of main economic and human resource indicators in China (1950-2000)

6.3 Health expenditure per capita in urban and rural areas (1996-2000)

6.4 Inpatient rate by disease in survey areas (1998) 139

6.5 Main health indicators by region (2001) 142

6.6 Care service availability index by region (1999) 144

6.7 Minimum requirements for the "Everybody enjoys health services in 2000" project (by county)

6.8 China's health expenditure (1991-2000)

7.1 Changes in sickness and treatment (1993-2003)

7.2 Urban and rural population not covered by medical insurance (1993-2003)

7.3 Urban population not participating in primary medical insurance (1998-2003)

7.4 Population without access to safe drinking water (2003) 159

7.5 Handicapped population in China (1987-2003) 159

7.6 Size of groups with health insecurity (2003) 160

7.7 Estimated economic cost of disease (2003) 162

8.1 Estimate of the sources of economic growth (1978-2003) 178

9.1 Estimates of real urban unemployment (1993-2000) 187

9.2 Estimate of urban unemployment ratio (1995-2000) 188

9.3 The real unemployment rate and real unemployment rate by region (1999)

9.4 Coverage of medical and occupational injury insurance schemes in China (1993-1999)

9.5 Coverage of urban unemployment insurance (1994-1999) (1996-1999) countries

9.8 The economic costs of lay-offs and unemployment (1997-2000) 
xiv List of tables

9.9 Change in the top five most important social problems concerning common people (1998-2000)

9.10 Calculation of employment elasticity (1986-2000)

9.11 Backgrounds and characteristics of the transformation of employment models in different periods

10.1 Genuine savings rate (1970-1993)

10.2 Natural capital and genuine domestic savings rate in China (1980-2001)

11.1 Economic costs of corruption (1999-2000)

12.1 Number of people's deputies per one million persons in various areas (2000)

12.2 Composition of people's deputies to all National People's Congresses (1954-1998) 


\section{About the author}

Dr. Hu Angang was born on April 27, 1953 in Anshan City, Liaoning Province. Dr. Hu received a Ph.D. in Engineering from the Chinese Academy of Sciences in 1988. He did post-doctoral study at the Department of Economics, Yale University from 1991 to 1992 . Dr. Hu has been to many world-famous universities as a visiting scholar, researcher and professor over the years. Dr. Hu was awarded an Honorary Ph.D. by the Far-eastern Institute, Russian Academy of Sciences in 2004.

In 1985, Dr. Hu joined the China Study Group of the Chinese Academy of Sciences as one of the leading researchers and began to conduct China Studies systematically. He is one of the pioneers of this new field. At the beginning of 2000, Dr. Hu directed the Center for China Study, one of the top think-tanks for national decision-making. He also worked as the chief editor for China Studies Report, a reference circulated for senior officials.

In 1991, Dr. Hu was awarded "Doctor with Special Contribution to China" by the State Education Commission and Academic Degree Committee of the State Council. In 1995, Dr. Hu received sponsorship from the National Science Fund for Outstanding Young Scientists of the Natural Science Foundation of China and was awarded Financial Aid for Chinese Economic Research from the Ford Foundation. Dr. Hu and his projects have received many awards and prizes, such as twice winning the first prize of the Science and Technology Progress Awards by the Chinese Academy of Sciences. In 2000, Dr. Hu's project was awarded first prize of the National Science Fund for Outstanding Young Men by the Natural Science Foundation of China. In 2001, Dr. Hu won the ninth Sun Yefang Economic Essay Award.

Dr. Hu Angang is a well-known Chinese economist and a leading researcher on China Studies in both China and overseas. His research focuses on China's macroeconomic development and development policies. Dr. Hu is a fruitful researcher: as of 2006, he had published a total of fifty-three books, among which are nine monographs, twenty collaborations as first coauthor, eight books published overseas with Chinese editions and six English edition books. Dr. Hu has published nearly 200 articles in the core periodicals and key academic magazines in China. His representative works include China's Population and Development (1989); Tentative Exploration into China's Industrialization (with 
Qing Guo, 1991); China: Toward the 21st Century (1991); China State Capacity Report (with Shaoguang Wang, 1993); China Economic Fluctuation Report (1994); China Regional Disparities Report (with Shaoguang Wang and Xiaoguang Kong, 1995); Employment and Development: China Unemployment Issue and Employment Strategies (1998); China Development Prospects (1999); China: Fighting Against Corruption (edited, 2000); Society and Development: Study on the Regional Disparities in Social Development in China (with Ping Zou, 2000); New Strategies of Western Region Development (2001); China Strategy Framework (2001); Influential China Study Reports for Making Decisions (edited, 2002); China's Grand Strategies (edited, 2002); China's Second Generation Reform Ideology: Focused on System Building (with Shaoguang Wang and Jianming Zhou, 2002); See Through SARS: Health and Development (edited, 2003); China: New Conception of Development (2004); Transformation and Stability (with Lianhe Hu, 2005); National Conditions and Development (with Yahua Wang, 2005); China's History of Political Economy: 1949-1976 (2006); Roadmap of China Rising (2006). From 2000 to 2005, his books and articles were cited 1404 times in China Social Science Citation Index (CSSCI), ranking one of the top ten among all Chinese scholars of social sciences. 


\section{Acknowledgments}

I am very grateful to a large number of my students and friends who have either coauthored some of the chapters or have helped me with the calculation of data and figures. I would like to thank Mr. Jianghai Zheng, and my students Honghua Men, Yizhi Xiong, Linlin Hu, Zhixiao Chang, Yuxin Yang and Chunbo Li for their input to the book.

I would especially thank Shaoging Jin, Xianfeng Gao, and Yuning Gao who have dedicated extraordinary effort and time, among many other tasks that they have, to working with me for arranging the translation, editing the book, checking the references, and finally making this book a reality.

My thanks go to all my colleagues and students at the Chinese Academy of Sciences and Tsinghua University. My heartfelt thanks also go to Mr. Shaoguang Wang and Mr. Jianming Zhou, who have contributed many lines of thoughts and achievements; to Tsinghua University and Oxfam Hong Kong, which have provided useful financial aid for our research on China studies.

I would like to express my special thanks to my wife Yining Zhao, whose meticulous care has made it possible for me to complete all the manuscripts in high spirits and pleasure despite suffering from long-term diabetes. I write with great concentration of mind and I would like to present the book to all readers who are concerned with the destiny of China and to my family members and friends who have shown great concern for my health. 



\section{Introduction}

\section{How I conducted this China Study}

As early as forty years ago, Chinese leader Mao Zedong said in his work "Ren de zhenque sixiang shi cong nali laide?"("Where do correct ideas come from?"): "Where do correct ideas come from? Do they drop from the sky? No. Are they innate in the mind? No. They come from social practices and from them alone. They come from three kinds of social practices, the struggle for production, the class struggle and scientific experiments. It is man's social being that determines his thinking." He also said: "Correct knowledge can be arrived at only after many repetitions of the process leading from matter to consciousness and then back to matter, that is, leading from practice to knowledge and then back to practice. Such is the Marxist theory of knowledge, the dialectical materialist theory of knowledge." 1

Our correct understanding of China's national conditions and their development needs a repeated process of practice, understanding and reflection. The practice of the Chinese people is the greatest social practice in human history. More than one billion Chinese people are engaging in the greatest reform and opening-up practice in an area of 9.6 million square kilometers of land and three million square kilometers of territorial waters with a dozen countries as its neighbors. The study of Chinese national conditions (or China Studies as it is called outside China) takes this great practice as the subject of study. Such study needs a repeated processing of knowledge, from perceptual to theoretical and from theoretical back to practice, to see which theories or policies can achieve the anticipated results, thus providing the correct guidance to China's practice of reform and opening up, and stimulating China's development.

Over the past half-century, three generations of Chinese leaders, Mao Zedong, Deng Xiaoping and Jiang Zemin, and Chinese intellectuals and scholars, have been ceaselessly probing into such problems as: Is socialist modernization necessary to a developing country with a long history, large population and vast territory with great regional disparities? What kind of socialist modernization should be realized? Can China realize modernization? How should China realize socialist modernization with distinct Chinese features? China's socialist modernization is a unique process based on China's basic national conditions. The more we know about the basic characteristics of China and its peculiarities (especially factors restricting development), the fewer policy errors we shall 
make and the fewer will be the economic and political prices to be paid. The more thoroughly we master the law governing China's economic development and the more comprehensively we sum up our development experience and lessons, the more capable we shall be in knowing and directing future development. But it not easy to attain a true understanding of China, as China has not only a time-honored history, but also a rich cultural tradition, and is in the process of unrivaled social transformations and rapid economic development.

I regard studying China and understanding China and its development not only as my life-long career and research direction but also as my biggest pursuit and enjoyment in life. China is the most populous country in the world and its reform and development constitute the greatest social practice in human history. The study of its national conditions has the most extensive social bases and social demands, and it can bring extensive social impacts. I have found the path of my life in my academic career. Its real implications are to grow with China's development, to keep company with China's opening up, to advance with China's reform and to live with the prosperity of the country.

For this purpose, I founded the Center for China Studies of the Chinese Academy of Sciences (CAS) in 1999. In the same year, CAS-Tsinghua Center for China Studies was established with Tsinghua University. The center aimed to become one of the most influential public policy study centers and thinktanks for high-level policy and decision-making.

In February 1998, I published the first China Studies Report entitled "Wei renmin chuangzao gongzuo: zhongguo de shiye wenti yu jiuye zhanlue", which discussed China's unemployment and employment strategies. It caught the attention of then Premier Zhu Rongji and Vice-Premier Wu Bangguo, who attached important commentaries on my report. I was greatly encouraged and was determined to make the China Studies Reports an information platform for collecting and sorting out major information about China's national conditions and establishing a national conditions policy-making databank to promote national conditions studies and education and to train senior researchers in public policies. By June 2005, we had published over 750 issues of China Studies Reports, which served as background material for central and local leaders in their reform and management, and introduced the views and recommendations of foreign experts on China's economic development.

The country's central leadership has paid close attention to the China Studies Reports and some recommendations were adopted in their decision-making. As a result, the influence of the China Studies Reports has increased and greater social benefits have been achieved. According to related statistics, fifty-seven issues of China Studies Reports and decision-making information have been submitted to the Party Central Committee and State Council and senior leadership have made sixty-two commentaries, among which fifty commentaries were made by Premiers of the State Council. China Studies Reports have played a very important role in influencing policy decision-making, reflecting the national economy and people's livelihood, disseminating policy-making knowledge. 
Great changes have taken place in China's political policy decision mechanism concerning the economic and social transformation of the country. In the Mao Zedong era, most of the major policy decisions were made by himself, such as the launching of the Great Cultural Revolution, establishing of the third defense line, and the restoration of Sino-US relations. That was a period of personal decision-making. In the Deng Xiaoping era, apart from displaying the core role of Deng Xiaoping, the Party's collective leadership became increasingly important. That may be regarded as a collective policy decision-making era. Since the 1990 s, the policy decision-makers are listening more and more to the experts. This has provided us with a good opportunity for becoming involved in policy and decision-making.

China is very special in its economy and society. In the process of modernization, China has met such great difficulties, so many contradictions and such complicated problems that they are not easy to understand or resolve. At present, China is presented with many development opportunities, but also unavoidable challenges. In a word, the uncertainty of risks and the incompleteness of knowledge about the development of China and the world have added to the difficulties and complexity of policy decisions.

On June 24, 2002, at an economic experts conference on Chinese economic polices chaired by Premier Zhu Rongji, I made a policy recommendation of "liberating the peasants for the third time", namely, to liberate the peasants, invest in peasants, transfer peasants, reduce the number of peasants and make peasants rich. Looking back at past events we would find that the leaders who had a profound understanding of agriculture, peasants and rural issues usually made better, more suitable policies as they were most closely based on the national conditions. They have therefore given a big push to China's development, because only the reforms that benefit the overwhelming majority of the population can be regarded as true reforms. Likewise, only those scholars who have made a profound study of agriculture, peasants and rural issues have achieved real academic attainment, because their knowledge has benefited the people, especially peasants.

After studying China's population, resources, environment, grain and economic development as a whole for a long time, I have arrived at two major understandings. First, the difficulties and crises China has met in its long-term development are more serious and complicated than we have imagined, and that has deepened our knowledge and understanding of the socio-economic reasons and underlying contexts for China's reform and development. Secondly, solutions for overcoming the difficulties and crises are more difficult and more arduous than we have imagined. It is hard to find a panacea.

It is, therefore, necessary to mobilize to the maximum and utilize more rationally all kinds of resources and forces of society to push forward the reform and modernization process fruitfully, firmly and forcefully; there is no going backwards. Meanwhile, it is necessary to tell the people what is really happening, helping the people of the entire country, especially the intellectual stratum, to understand how the sense of backwardness and the sense of crisis concomitant 
to the process of opening up to the outside world will clash with the nationalistic consciousness of self-confidence and the sense of self-improvement. This will give rise to a common understanding of the long-term nature, arduousness and painfulness of reform and development. It is necessary to prepare the people for a long, hard struggle to get out of crises and difficulties so as to revitalize the Chinese nation in the twenty-first century.

My basic understanding of China's national conditions is that we should be neither blindly optimistic nor pessimistic about the prospects of China's future development. Instead, we should take a cautiously upbeat attitude. In the future, we should follow neither radical revolutionary means nor conservative reformist ways. Rather, we should opt for incremental development. We should imitate neither the ways of Western developed countries, nor the traditional modernization models of the former Soviet Union and other socialist countries, nor should we continue along the original models already traversed by China. Rather, we should opt for a unique model of socialist modernization and development best suited to China's national conditions.

People ask me why my recommendations were adopted by the central authorities not long after they were put forward. Policy decision-making by the central authorities is never economic policy decision-making pure and simple, but economic and political policy decision-making. China's economic problems cannot be studied simply from economic perspectives. Instead, we must study them from the social angle and - especially - from the political angle. I have always held that the regional gap is not only an economic issue, but is or has been a political issue. That is why I approach the issue not merely from the economic perspective as a simple geographical issue, but deal with the issue both from economic and political perspectives.

An economist is an "engineer" who brings benefits to mankind. As an intellectual, his biggest contribution to mankind is knowledge. Compared with other scientists and intellectuals, an economist has more opportunities and better conditions for making such contributions. Economics itself is a way of "governing and benefiting the people" by exploring ways of creating wealth. Economic growth theories study why some countries grow faster than others. An economist does not study how to create wealth for individuals, but how to do so for the people and the country. What he provides is a kind of "public good", namely "knowledge," which has a strong externality and benefits others and the society.

Many issues in China cannot be resolved without approaching them politically. Only when an issue provokes a response from big shots in the policy decision-making process and is turned into public policies, is it possible to finally arrive at a common understanding and resolution of problems. Over the years, the central policy decision-makers have become more and more attentive to the views of experts and common people alike. This is known as making policy decision-making more scientific and more democratic. To make the Chinese nation prosper and the motherland strong is both the goal of my lifelong struggle and the purpose of my academic studies. What I am concerned about are the problems concerning the common people, such as layoff problems, 
social security problems, peasant income problems, poverty in areas inhabited by minority people, and inflation.

Most scholars follow the principle of division of labor. When one studies economic issues, he would never touch upon politics. When one studies macroeconomic problems, he would never touch upon microeconomic issues; when one studies the economy of the United States, he would not care about the economy of Japan. However, my stories are closely associated with China's reform and opening up because I study China's national conditions and therefore I must start from the hot issues, the difficult and disputable issues that are in need of urgent solution for economic and social development. What I focus on are the most important issues concerning the development and progress of the entire society instead of limiting myself to any particular discipline or theoretical problems.

I hold that an outstanding scholar must lead the social tide instead of just flowing with it. Both scholars and leaders can lead the social tide and promote social development. The difference lies in the fact that scholars lead society by relying on correct ideas and correct views. When the public agrees and accepts our ways, correct thinking and views will play their leading role. Leaders, however, standardize the behavior of the people by taking advantage of state authority, which may be persuasive and coercive. But how to lead the tide? I think this depends on whether or not we can obtain new knowledge. This requires international exchange. It also depends on knowing, absorbing, understanding and accumulating the best knowledge already known to mankind. Here, the personal knowledge-holding capacity plays a crucial role. Thirdly, it depends on the localization of international knowledge.

I often quote the latest research achievements in the world. After the World Bank published its World Development Report: Knowledge for Development in 1998, I came out with China's knowledge development strategy for the twenty-first century, which is regarded as the third generation of the catchingup strategy. Mao Zedong's heavy industrialization can be regarded as the first generation of the catching-up strategy, which was not very successful. Deng Xiaoping's reform and opening up may be regarded as the second generation of the catching-up strategy, which was relatively successful. The knowledge development strategy should become a new catching-up strategy to answer the challenges of economic globalization and the development of information technology. I have not only put forward the general strategy for China, but also analyzed the regional gaps in knowledge development, thus evolving the new catching-up strategy for various regions, that is, the knowledge development strategy.

The study of national conditions often touches upon the most sensitive issues and those at the forefront of political and economic reform, and the recommendations raised are often forceful and forward-looking. The sharp mastery of the political and economic situation has made my study strikingly synchronized with policy adjustments. It is exactly these acute innovations that have influenced the policy decision-making process and the society as a whole, thus 
realizing my academic purpose of "being eager to meet the urgent needs of the state and thinking as the state thinks" established at the outset of my entry into the field of national conditions study.

In April 1996, the US Newsweek magazine called my economic policy recommendations a Chinese New Deal. The Japanese World Affairs Weekly carried my "Report on Regional Gaps in China" in its April 9, April 16 and April 23 issues, and called it the boldest and the most clear-cut exposition in recent years to provide Japanese readers with a comprehensive picture of the regional gaps in China. On September 15, 1997, the US Time magazine (Asian edition) said that "Hu openly demands policies to close the gaps between rich and poor regions." The American China Economic Studies described the "Report on China's State Capabilities" coauthored by myself and Wang Shaoguang of the Political Department of Yale University as "one of the most influential and also the most disputed literatures concerning China's economy in recent years."

Each era has its unique economic environment and also its unavoidable economic crises. Economists are "the wise ones" who understand and solve these economic issues. Although there have been no fundamental changes in the basic principles of economics, economists are able to use these principles flexibly and creatively to know and analyze crises and actively cope with challenges. Economists play an indispensable social role in different countries or during different periods of time in a country. They are probably the first to witness economic and social crises and they are the experts in handling these crises.

My policy recommendations proved influential for state policy decisionmaking. It is not because I have any particular political background or personal connections, but because my policy and what I have studied, political or economic, and even the most sensitive political issues, are all closely associated with the fundamental, long-term and maximum interests of 1.3 billion people. I am not only very clear about where their interests lie but also very clear about how to enable policy decision-makers to understand this through my China Studies Reports. At the same time, I have the idea of "telling the people and the whole society what is right." I believe that policy decisionmakers are rational and wise enough; and I believe ever more that the people and society are capable enough to tell what is right and what is wrong.

Take the government unemployment and employment policies and strategies for example. As early as 1997 I made it very clear that the first and foremost tasks for economic development after the first successful soft landing of the macro economy were to expand employment and reduce the unemployment rate. Since then, I have constantly alerted the policy decision-makers and the whole society to the biggest challenge China would face in the twenty-first century - that it had entered the high unemployment stage, as in one of my research reports entitled "Kuaru xinshiji de zuida tiaozhan: woguo jinru gaoshiye jieduan" (The Greatest Challenge Entering the Twenty-First Century: China Enters the High Unemployment Stage) (1999). The central economic conferences and government work reports later all arrived at the basic judgment that 
"China's employment pressure is mounting," until in September 2002, Jiang Zemin and Premier Zhu Rongji described China's employment situation as "very grave." In November 2002, President Jiang Zemin in his report to the Sixteenth National Congress of the Communist Party clearly pointed out that to increase employment was a key and difficult task for us at present and in the long run. The government will adopt long-term policies and strategies to increase employment. $^{2}$ This is one example of how my policy researches and recommendations directly influenced the formation of central government policies.

China's reform and opening up have attracted worldwide attention. All the new problems encountered in the course of reform and development need rational analysis and solutions using the principles of economics. This has provided our new generation of scholars with a vast stage for carrying out academic studies. We are lucky to live in this era, in which we may make contributions to society by obtaining, innovating, spreading and exchanging knowledge. I will continue my studies, as there will always be new challenges and new issues to pursue in the course of my studies. These challenges and new issues are so inexhaustible that I cannot pull myself away from them. To grapple with these challenges and new issues gives me pleasure.

I believe that the spread of knowledge is not competitive. I may enlighten you and you may also enlighten others. The important tasks of the Center for China Studies are to obtain, absorb, innovate and spread knowledge.

In recent years, I have published a series of books on China Studies. However, most of my researches are published in Chinese. Only a few of my researches have been translated into English and been formally introduced to overseas readers. In the past several years, I have participated in international symposiums and seminars on various occasions and have conducted joint studies with foreign researchers. In October 2005, I started to collect all these papers together and printed them in an informal brochure to share with my fellow foreign researchers. In November 2005 in South Korea, when participating in a conference sponsored by POSCO, I gave Peter Nolan one copy as a personal present. Peter encouraged me to have it edited and formally published in English to be made available to English readers.

This resulting book is a collection of research papers that I have presented at international symposiums and seminars, as well as joint researches. In these papers, I have tried to explain the sources for China's fast economic growth, the challenges in Chinese economic development, the costs of China's development and its great transformations and the transition of the focus of the Communist Party from economic development to institution building.

The book provides a large amount of information with numerous tables and figures. All these data demonstrate that China is experiencing four transformations simultaneously, unprecedented in human history in terms of scale and complexity: economic system transformation, a transformation from a planned economy to a socialist market economy; social transformation, a transformation from a traditional agricultural and rural-based society to a modern industrial and service-based urban society; political system transformation, a transformation 


\section{Economic and social transformation in China}

from a traditional centralized political system to a socialist democratic political system; and an opening-up transformation, a transformation from a closed economy and society to an open economy and society. China's transformation is a transformation of 1.3 billion people, a transformation of 800-900 million rural people, a transformation of 5000 years of Chinese civilization. It is unprecedented in Chinese history, even in world history in terms of its large-scale population, the fast speed of transformation, the profound impacts on China and the world, the complexity of social conflicts. I feel very much honored to have witnessed, experienced, observed, and more importantly promoted these transformations using my knowledge in China Studies accumulated over twenty years.

Generally speaking, challenges are unavoidable in such multi-dimensional transformations, and crisis is the norm. The key in this transformation is to respond to the challenges proactively, to identify crises timely, to emphasize social order, and to reduce transformation costs.

The chapters in this book record how China is transforming itself, the challenges it faces, and how it is responding to these challenges. It is a record of the history of China's transformation and an analysis of that history, as well as a reflection of history itself. China's transformation is far from complete, as new challenges will appear in the future, but through our studies we are confident that we are more active in responding to the challenges than at any other time. To some extent, China's model is a typical learning model: learning by doing, doing by learning. From this perspective, this book is my personal experience of learning. To have this book published in English is to introduce my experiences to foreign readers. 


\section{Why has China's economy grown so fast? ${ }^{1}$}

\section{A successful catch-up paradigm of modernization}

In the world as a whole, modernization of all countries is a process of mutual association, mutual competition and mutual development. Many countries, though they started late, have caught up with or surpassed the countries that have led the modernization process.

In terms of modernization, there are countries that lead and countries that lag behind, countries that are advanced and countries that are backward, countries that are catching up and countries that are left behind. In terms of technology, countries may also be divided into innovators and pursuers as well as leaders and imitators. By backwardness, I mean a kind of relative state of being behind others. Countries that are left behind are the countries that are in a state of relative backwardness. A country that is left behind is a country that starts relatively late in launching and entering industrialization rather than a country that is relatively backward in economic development at a certain point of time, as Alexander Gerschenkron puts it. ${ }^{2}$

The history of modern economic development shows that there have been four successful catch-up paradigms. One is the United States, which spent fortythree years catching up with Britain at the turn of the nineteenth and twentieth centuries. According to data from Angus Maddison, the per capita GDP of the United States in 1820 was only 73.3 percent that of Britain, and reached 75.3 percent in 1870. Starting from 1870, the United States initiated an economic takeoff, registering an average annual per capita GDP growth of 3.9 percent from 1870 to 1913 as opposed to 1.9 percent in Britain over the same period. By 1900, the US average per capita GDP rose to 89.2 percent that of Britain and up to 105.5 percent, surpassing Britain by $1913 .^{3}$

The second example is the former Soviet Union, which caught up with the United States during the great economic depression. During 1928-1939, the GDP growth rate of the former Soviet Union was 5.6 percent while that of the United States was only 0.8 percent. The per capita GDP of the former Soviet Union was 20.8 percent that of the United States in 1928 and it rose to 34.1 percent by 1939 , demonstrating the catch-up effect. 


\section{Economic and social transformation in China}

The third example is Japan, which took forty years to catch up with the United States. In 1950, the per capita GDP of Japan was 19.6 percent that of the United States. In 1953, Japan's GDP growth surpassed the highest level during World War II, starting a takeoff. From 1953 to 1992, Japan's annual GDP growth averaged 6.5 percent while that of the United States was only 3.0 percent. By 1992, Japan's per capita GDP amounted to 90.1 percent that of the United States. Japan was regarded as the most successful country in the catchup game and it set a world record (an annual growth rate of 1.95 percent) in increasing the per capita income in 1982-1992 by twenty-eight-fold.

The fourth example is what is known as the "four little dragons" in Asia, which took thirty years to catch up with the developed Western countries. From 1965 to 1992, the GDP of the Republic of Korea (ROK) and Taiwan Region grew at an average annual rate of 8.8 percent. The per capita GDP of ROK and Taiwan was only 24.3 percent and 31.4 percent that of the Western European countries (twelve countries) respectively. But it reached 57.5 percent and 66.6 percent, respectively, by 1992 (see Table 1.1).

Why can latecomers catch up with forerunners? What are the objectives and strategies for the catch-up game? According to Alexander Gerschenkron, backwardness has an advantage in so far as latecomers to industrialization enjoy

Table 1.1 Less advanced countries catch up with advanced ones

\begin{tabular}{|c|c|c|c|c|}
\hline & \multirow[t]{2}{*}{ Period } & \multirow[t]{2}{*}{$\begin{array}{l}\text { GDP } \\
\text { growth (\%) }\end{array}$} & \multicolumn{2}{|c|}{$\begin{array}{l}\% \text { in per capita GDP } \\
\text { of forerunners }\end{array}$} \\
\hline & & & $\begin{array}{l}\text { Beginning } \\
\text { period }\end{array}$ & $\begin{array}{l}\text { End } \\
\text { period }\end{array}$ \\
\hline \multicolumn{5}{|l|}{ First catch-up } \\
\hline Britain & $1871-1913$ & 1.9 & 100.0 & 100.0 \\
\hline United States & & 3.9 & 75.3 & 105.5 \\
\hline \multicolumn{5}{|l|}{ Second catch-up } \\
\hline United States & $1928-1939$ & 0.8 & 100.0 & 100.0 \\
\hline Soviet Union & & 5.6 & 20.8 & 31.4 \\
\hline \multicolumn{5}{|l|}{ Third catch-up } \\
\hline United States & $1953-1992$ & 3.0 & 100.0 & 100.0 \\
\hline Japan & & 6.5 & 19.6 & 90.1 \\
\hline \multicolumn{5}{|l|}{ Fourth catch-up } \\
\hline Western Europe (12 countries) & 1965-1992 & $\cdot$ & 100.0 & 100.0 \\
\hline $\mathrm{ROK}$ & & 8.8 & 24.3 & 57.5 \\
\hline Taiwan Province & & 8.8 & 31.4 & 66.6 \\
\hline \multicolumn{5}{|l|}{ Fifth catch-up } \\
\hline Western Europe (12 countries) & $1978-1995$ & 1.74 & 100.0 & 100.0 \\
\hline China & & 7.49 & 9.1 & 19.0 \\
\hline
\end{tabular}

Source: A. Maddison, Monitoring the World Economy 1820-1992, Paris: OECD, 1995.

Notes: Calculation based on 1990 Geary-Khamis Dollar. 
special benefits and advantages, including the introduction of technologies and equipment from advanced countries. This is the first and foremost factor that can ensure that countries lagging behind in industrialization gain a high-speed growth. The substitution of R\&D by technology imports can accelerate the pace of industrialization and avoid risks. In addition, latecomers can learn from the successful experiences of the advanced countries and draw lessons from their setbacks. Latecomers can optimize and diversify the design of their industrialization models innovatively. There is no need for them to repeat the errors experienced by forerunners, such as "pollute first and control later." They can also choose a faster development path and more open development policies. For instance, economic globalization has provided external conditions for transitional countries in the process of reform to accelerate the development of market mechanisms. An efficient reformer learns faster than others. But how to learn and how to ensure not being left behind depend not only on the initial conditions, but also on the ways of learning. ${ }^{4}$ Last but not the least is the strong sense of "catch-up." The more backward the latecomer is, the stronger the desire for catching up and the greater success it will achieve. The tremendous and sudden spurt of a backward country is a "new deal" spiritually. ${ }^{5}$

According to the new economic growth theories, there are three decisive factors that determine whether or not a poor country can catch up with a rich country. One is the level of savings. The higher the savings rate, the faster the per capita GDP growth rate. The second factor is the opening of the economy. International capital inflow helps accelerate the catch-up process. The third is the speed of technology diffusion. As the cost of imitating and using the technologies and inventions of the forerunners is much lower than the cost of self-innovation, latecomers may overtake technically advanced countries in terms of growth. ${ }^{6}$ The bigger the gaps in technology between the technology forerunners and technology importers, the greater gains the imported and imitated products will have, thus revealing the catch-up effect. If a technology importing country has a big economy, the gains or overflowing effect of imported technology products will demonstrate the efficiency of a big economy.

\section{China's economy in retrospective: from decline to rise}

China is a typical latecomer in industrialization. It started late in launching industrialization and the time for full industrialization has lagged greatly. If we say that Europe and North America began industrialization from 1750, then China started the process 100 to 200 years later. In other words, the official start of industrialization in China was 1950.

China was not only late in starting industrialization, but it also started at a very low point. The per capita income of Europe and the United States at the time of starting industrialization was much higher than that of China. According to the world economic history expert Angus Maddison (see Table 1.1), the per capita GDP (1990 PPP international dollar) was US \$1024 and it rose to US $\$ 1232$ in 1820 . The per capita GDP of the United States was US $\$ 600$ in 1700 


\section{Economic and social transformation in China}

and US \$1260 in 1820 . But in China, the per capita GDP was only US \$439 in 1950, much lower than the level of the United States when it started industrialization in 1820 .

At the beginning of the 1950s, the per capita income level of China was much lower than that of industrialized countries in Europe and North America, showing a tremendous development gap. In 1950, the per capita GDP in Western Europe was 10.5 times that of China; the per capita GDP of the United States was 21.8 times that of China; and the per capita GDP of Russia was 6.5 times that of China. Even the per capita GDP of Japan was 4.4 times that of China (see Table 1.2). China's per capita GDP was also lower than that of India (US \$619). China was one of the poorest countries in the world.

Over the past half century, China's economy has experienced rapid growth and began to take wing in 1978. The gap between China and the developed countries in terms of average per capita GDP has been greatly narrowed. In 1998, China's per capita GDP was US \$3117. The gap with Western European countries narrowed to 5.8 times, the gap with the United States narrowed to 8.8 times, the gap with Japan narrowed to 6.6 times, and the gap with the world average narrowed to 1.83 times (see Table 1.2). China demonstrates a catchup model in narrowing the gap with developed countries in modernization (see Figure 1.1).

China is one of the countries with the most ancient civilization. Its development history is unique. It has enjoyed long-term prosperity. For a considerably long period of time, China was one of the biggest and the most economically advanced countries in the world. Its position dropped drastically in 1820 and reached its nadir by 1950, but it rose again from 1978 .

According to the calculation by Maddison, China's GDP was one-third (32.9 percent) of the world total in 1820 when it reached its peak. ${ }^{7}$ It was an

Table 1.2 Per capita GDP comparisons among selected economies (1820-1998)

\begin{tabular}{|c|c|c|c|c|c|c|c|}
\hline & 1820 & 1870 & 1913 & 1950 & 1973 & 1978 & 1998 \\
\hline \multicolumn{8}{|c|}{ Per capita GDP (1990 Geary-Khamis Dollar, PPP) } \\
\hline China & 600 & 530 & 552 & 439 & 839 & 979 & 3117 \\
\hline Japan & 669 & 737 & 1387 & 1926 & 11439 & 12581 & 20413 \\
\hline US & 1257 & 2445 & 5301 & 9561 & 16689 & 18373 & 27331 \\
\hline Western Europe & 1232 & 1974 & 3473 & 4594 & 11,534 & 12674 & 17921 \\
\hline World & 667 & 867 & 1510 & 2114 & 4104 & 4382 & 5709 \\
\hline \multicolumn{8}{|c|}{ Per capita GDP comparison (China is 1.0 ) } \\
\hline China & 1.0 & 1.0 & 1.0 & 1.0 & 1.0 & 1.0 & 1.0 \\
\hline Japan & 1.12 & 1.39 & 2.51 & 4.38 & 13.63 & 12.58 & 6.55 \\
\hline US & 2.10 & 4.61 & 9.60 & 21.8 & 19.89 & 18.77 & 8.77 \\
\hline Western Europe & 2.05 & 3.72 & 6.29 & 10.46 & 13.74 & 12.95 & 5.75 \\
\hline World & 1.11 & 1.64 & 2.74 & 4.82 & 4.89 & 4.48 & 1.83 \\
\hline
\end{tabular}

Sources: A. Maddison, Monitoring the World Economy, 1995; A. Maddison, The World Economy: A Millennial Perspective, OECD: Paris, 2001, Table B-21.

Notes: Calculation based on 1990 Geary-Khamis Dollars. 


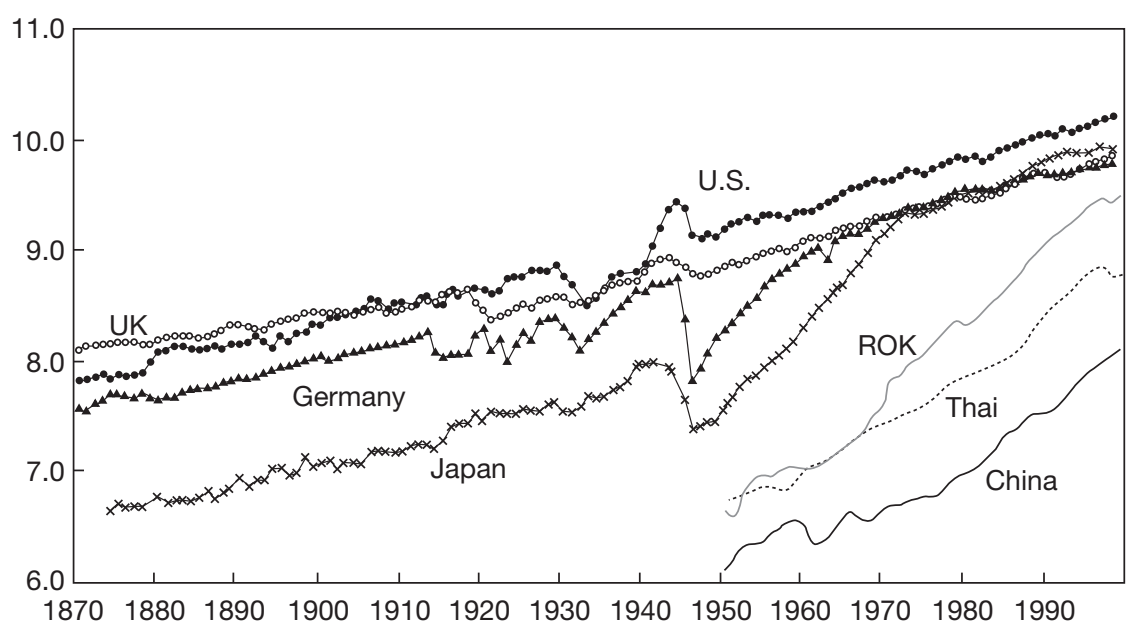

Figure 1.1 Per capita GDP comparisons of major countries (1870-1998)

Source: A. Maddison, Monitoring the World Economy; A. Maddison, The World Economy: A Millennial Perspective, Paris: OECD, 2001, Table B-21.

economically strong power in the world, followed by India, whose GDP accounted for 16 percent of the world total. France was ranked third, Britain fourth, Germany fifth. But in 1950, the United States ranked first, with its GDP accounting for 27.3 percent, followed by the Soviet Union, Britain, and Germany. China was pushed back to fifth, with its share of GDP in the world total dropping to 4.5 percent. In 1973, the United States and the Soviet Union remained the first two, with Japan ranking third and Germany fourth. China remained fifth. In 1998, the United States stayed in first place while China rose to second, with the share of its GDP in the world total rising to 11.5 percent. Japan was in third place, India fourth, and Germany fifth (see Table 1.3).

China was ready for an economic takeoff period at the beginning of the 1980s. From 1978 to 2003, its GDP grew at an average annual rate of 9.3 percent, far higher than the world average. China was one of the fastest growing economies in the world during this period (see Table 1.4). In the 1980s, the world GDP aggregate increased at an average annual rate of 3.3 percent. From 1990 to 2002, it was 2.7 percent. In the same period, China recorded the fastest growth among the world's major five economies (see Table 1.5). If calculated by PPP, China's GDP in 2002 was 12 percent of the world total, placing it second, just behind the United States (see Table 1.6).

China's industrialization process has accelerated to the extent that it has become the biggest country in the world in terms of the output of manufactured goods and added values. The growth of economic aggregate in China is, to a large extent, the result of the rapid growth of industry, particularly the manufacturing industry. From 1978 to 2003, the industrial added value grew at an average annual rate of 11.5 percent, much higher than the world average 


\section{Economic and social transformation in China}

Table 1.3 Percentage of GDP of major countries in the world total (1820-1998) (\%)

\begin{tabular}{lrrrrrr}
\hline Countries & 1820 & 1870 & \multicolumn{1}{c}{1913} & 1950 & 1973 & 1998 \\
\hline Western Europe & 23.6 & 33.6 & 33.5 & 26.3 & 25.7 & 20.6 \\
Britain & 5.2 & 9.1 & 8.3 & 6.5 & 4.2 & 3.3 \\
France & 5.5 & 6.5 & 5.3 & 4.1 & 4.3 & 3.4 \\
Germany & 3.8 & 6.5 & 8.8 & 5.0 & 5.9 & 4.3 \\
US & 1.8 & 8.9 & 19.1 & 27.3 & 22.0 & 21.9 \\
Former Soviet Union & 5.4 & 7.6 & 8.6 & 9.6 & 9.4 & 3.4 \\
Japan & 3.0 & 2.3 & 2.6 & 3.0 & 7.7 & 7.7 \\
China & 32.9 & 17.2 & 8.9 & 4.5 & 4.6 & 11.5 \\
India & 16.0 & 12.2 & 7.6 & 4.2 & 3.1 & 5.0 \\
Asia & 56.2 & 36.0 & 21.9 & 15.5 & 16.4 & 29.5 \\
Latin America & 2.0 & 2.5 & 4.5 & 7.9 & 8.7 & 8.8 \\
Africa & 4.5 & 3.6 & 2.7 & 3.6 & 3.3 & 3.1 \\
World & 100.0 & 100.0 & 100.0 & 100.0 & 100.0 & 100.0 \\
\hline
\end{tabular}

Source: Maddison, The World Economy: A Millennial Perspective, Table B-20.

Notes:

1. Data for Asia do not include Japan.

2. Calculation based on 1990 Geary-Khamis Dollar.

Table 1.4 Four fastest developing economies during different periods of time in the world

\begin{tabular}{ll}
\hline Period & Country \\
\hline 1870 s (a) & Germany, Belgium, the Netherlands, and Austria \\
1880 s (a) & Germany, Finland, Austria, and Denmark \\
1970 s (a) & Botswana, Malta, Singapore, and ROK \\
1980 s (a) & ROK, China, Botswana, and Thailand \\
1990 s (b) & China (10.3), Vietnam (7.9), Singapore (7.8), and Ireland (7.8) \\
\hline
\end{tabular}

Sources:

(a) Data for the nineteenth century are based on the estimates by Maddison, Monitoring the World Economy 1820-1992; data for the twentieth century are based on the estimates by the World Bank; see M. Olson, "Big Bills Left on the Sidewalk: Why Some Nations Are Rich, and Others Poor," Bijiao (Comparative Studies), 2003, Issue No. 7, pp. 21-38.

(b) World Bank, World Development Report 2002: Building Institutions for Markets, New York: Oxford University Press, 2002, pp. 236-237.

growth. The world average industrial growth was 3.1 percent in the $1980 \mathrm{~s}$ and 2.1 percent in 1990-2002. China recorded the fastest industrial growth among the five major powers in terms of production size and added value. Calculated by PPP, China's industrial added value made up only 3.4 percent of the world total in 1975, but doubled (to 6.8 percent) in 1990 and doubled again in 1995 (to 13.6 percent). By 2002, it already exceeded 20 percent (21.5 percent precisely), when it overtook the United States and ranked first in the world (see Table 1.7).

In a word, the past twenty-five years was a period of tremendous changes in China. It witnessed the fastest economic growth, the accelerated speed of 
Table 1.5 Economic growth comparisons of five major countries (1980-2002) (\%)

\begin{tabular}{|c|c|c|c|c|c|c|c|c|}
\hline \multirow[t]{2}{*}{ Country } & \multicolumn{2}{|c|}{ GDP (annual) } & \multicolumn{2}{|c|}{$\begin{array}{l}\text { Agriculture value } \\
\text { Added (annual) }\end{array}$} & \multicolumn{2}{|c|}{$\begin{array}{l}\text { Industry value } \\
\text { Added (annual) }\end{array}$} & \multicolumn{2}{|c|}{$\begin{array}{l}\text { Service value } \\
\text { Added (annual) }\end{array}$} \\
\hline & $\begin{array}{l}1980- \\
1990\end{array}$ & $\begin{array}{l}1990- \\
2002\end{array}$ & $\begin{array}{l}1980- \\
1990\end{array}$ & $\begin{array}{l}1990 \\
2002\end{array}$ & $\begin{array}{l}1980- \\
1990\end{array}$ & $\begin{array}{l}1990- \\
2002\end{array}$ & $\begin{array}{l}1980- \\
1990\end{array}$ & $\begin{array}{l}1990 \\
2002\end{array}$ \\
\hline China & 10.3 & 9.7 & 5.9 & 3.9 & 11.1 & 12.6 & 13.5 & 8.8 \\
\hline India & 5.7 & 5.8 & 3.1 & 2.7 & 6.9 & 6.0 & 6.9 & 7.9 \\
\hline Japan & 4.1 & 1.3 & 1.3 & -2.9 & 4.2 & 0.0 & 4.2 & 2.2 \\
\hline Russia & & -2.7 & & -1.9 & & -4.5 & & -0.6 \\
\hline US & 3.5 & 3.3 & 3.3 & 3.8 & 3.0 & 3.4 & 3.3 & 3.7 \\
\hline World & 3.3 & 2.7 & 2.6 & 1.8 & 3.1 & 2.1 & 3.5 & 3.1 \\
\hline
\end{tabular}

Source: World Bank, World Development Indicators 2004 CD-ROM.

Notes: Calculated using current international dollars, PPP.

Table 1.6 Comparisons of economic indicators of five major countries (2002)

\begin{tabular}{lllllll}
\hline Country & $\begin{array}{l}\text { Per capita } \\
\text { GDPPPP } \\
\text { (Current } \\
\text { inter- } \\
\text { national \$) }\end{array}$ & $\begin{array}{l}\text { GDP PPP } \\
\text { (Current } \\
\text { inter- } \\
\text { national }\end{array}$ & $\begin{array}{l}\text { \% billion) } \\
\text { in world } \\
\text { GDP }\end{array}$ & $\begin{array}{l}\text { \% of } \\
\text { industry } \\
\text { in GDP }\end{array}$ & $\begin{array}{l}\text { Industry } \\
\text { added } \\
\text { value } \\
\text { (US \$ } \\
\text { billion) }\end{array}$ & $\begin{array}{l}\text { \% in } \\
\text { world's } \\
\text { total } \\
\text { industry } \\
\text { value added }\end{array}$ \\
\hline China & 4580 & 5860.9 & 12 & 51.1 & 2954 & 21.5 \\
India & 2670 & 2799.6 & 5.7 & 26.6 & 722 & 5.34 \\
Japan & 26940 & 3425 & 7.2 & 30.6 & 1114 & 7.51 \\
Russia & 8230 & 1185.6 & 2.4 & 33.8 & 431 & 2.87 \\
US & 35750 & 10308 & 21.5 & 23.1 & 2604 & 17.1 \\
World & 7867.9 & 48771 & 100 & 28.6 & 14539 & 100 \\
\hline
\end{tabular}

Source: Ibid.

Notes: Calculated in current international dollars, PPP.

industrialization and urbanization, and the acceleration of world economic globalization. Unprecedented changes also took place in methods of production, ways of living and ways of thinking, a situation that has never been seen for thousands of years.

\section{Sources of China's economic growth}

China entered the economic takeoff stage around 1980 and maintained highspeed growth for a generation. What are the sources of China's economic growth? What determines and affects China's economic growth? What are the changes in its growth pattern?

Domestic and foreign studies show that since reform and opening up to the outside world, the key to higher economic growth compared to economic growth 
Table 1.7 Percentage of industry value added, export trade of five major countries in the world total (1975-2002) (\%)

\begin{tabular}{lccccccc}
\hline & 1975 & 1980 & 1985 & 1990 & 1995 & 2000 & 2002 \\
\hline $\begin{array}{l}\text { Industry } \\
\text { China }\end{array}$ & 3.39 & 4.05 & 5.47 & 6.76 & 13.6 & 18.5 & 21.5 \\
India & 2.11 & 2.19 & 2.83 & 3.54 & 4.44 & 4.93 & 5.34 \\
Japan & 8.59 & 8.61 & 9.00 & 9.97 & 8.94 & 7.97 & 7.51 \\
Russia & & & & 6.54 & 3.00 & 3.02 & 2.87 \\
US & 19.5 & 19.2 & 18.9 & 17.6 & 17.9 & 17.8 & 17.1 \\
Export trade & & & & & & & \\
China & 0.66 & 0.62 & 1.34 & 1.44 & 2.63 & 3.54 & 4.56 \\
India & 0.56 & 0.50 & 0.54 & 0.52 & 0.61 & 0.80 & 0.97 \\
Japan & 6.22 & 6.31 & 8.53 & 7.34 & 7.52 & 6.50 & 5.56 \\
Russia & & & & 2.17 & 1.81 & 1.45 & 1.50 \\
US & 13.50 & 12.20 & 13.35 & 12.91 & 12.80 & 13.95 & 12.68 \\
\hline
\end{tabular}

Source: World Bank, World Development Indicators 2004 CD-ROM.

Notes: Calculated in current international dollars, PPP.

prior to reform lies in the surge of total factor productivity (TFP) ${ }^{8}$ An analysis by the author shows that there were four major sources of economic growth from 1978 to 1995: (1) high-speed growth of labor (2.6 percent); (2) high-speed growth of capital stock $(9.3$ percent, though a bit lower than the growth rate of 11.5 percent from 1952 to 1978); (3) human capital calculated by the average years of education for employment populations above the age of 15 grew at an average annual rate of 2.2 percent; and (4) TFP rose from -1.9 percent before reform (1952-1978) to 3.3-4.5 percent (calculated by different weights of capital or labor), with contribution to economic growth being 33-47 percent. The results of these calculations are fairly close to the major conclusions of international studies, such as that by the World Bank ${ }^{9}$ and Maddison. ${ }^{10}$

This demonstrates that the high-speed economic growth during reform was not the aftermath of capital growth but because the growth of TFP rose from negative to positive, rising by 5.2-6.5 percent compared with that before reform.

In analyzing the sources of economic growth, we have used another method to construct a growth model. This is a comprehensive growth framework covering capital, labor, institutional change, and knowledge. The per capita GDP is used as the variant of output. Capital is the indicator of per capita capital stock, labor is the employment participation indicator to reflect the impact of population change on labor supply, institution is the institutional accumulation indictors (ten indicators), and knowledge is the knowledge accumulation indicators (ten indicators). For the calculation results, please refer to Table 1.8.

First, about half of the per capita output growth came from per capita capital growth. The per capita growth was 8.5 percent during this period, assuming a fairly high capital deepening process. This reflects the fact that China's economic growth was capital driven. 
Table 1.8 Sources of China per capita output growth (1978-1998)

\begin{tabular}{lllc}
\hline & $\begin{array}{l}\text { Regression } \\
\text { parameter }\end{array}$ & $\begin{array}{l}\text { Contribution to } \\
\text { growth (\%) }\end{array}$ & $\begin{array}{l}\text { \% of } \\
\text { contribution }\end{array}$ \\
\hline Per capita capital stock & 0.5 & 4.136 & 50.5 \\
Institutional changes & 0.578 & 2.765 & 33.8 \\
Knowledge development indicators & 0.375 & 1.469 & 18.0 \\
Total & - & 8.370 & 102.3 \\
\hline
\end{tabular}

Source: Xiong, Yi zhishi wei jichu de fazhan zhanlue yanjiu.

Notes: Knowledge development index (KDI) consists of three categories of index, capacity for acquiring knowledge, capacity for absorbing knowledge, and capacity for communicating knowledge. Capacity for acquiring knowledge consists of science and technology papers (per million population), patent application by residents (per million population), percentage of net FDI in GDP. Capacity for absorbing knowledge consists of years of education per capita (years), primary education enrollment rate (\%), secondary education enrollment rate (\%), and higher education enrollment rate (\%).Capacity for communicating knowledge consists of popularization rate of television (\%), popularization rate of telephone (including mobile telephone) (\%), and popularization rate of the internet (\%).

Secondly, one-third of the per capita output growth came from institutional changes. This reflects the fact that reform has been the engine or driving force of economic growth. The growth of the institutional accumulation indicator during this period was 5.2 percent. This indicates a fairly high speed of institutional changes.

Thirdly, one-fifth of the per capita output growth came from knowledge development. This shows that knowledge development has become a major source of economic growth, though it may not be the major driving force behind China's economic growth. The knowledge accumulation indicator growth was 3.7 percent during this period. This was a fairly high speed of knowledge innovation, import, absorption, dissemination, and application. It evidently demonstrates the big country effect.

This method of calculation better interprets the sources for China's economic growth. It implies that institutional changes can be stimulated through reforms, and knowledge development can be promoted through opening up and technical innovation. Thus, policies can be made accordingly to achieve sustainable growth in the future. This means that China should make technology and knowledge, rather than capital and natural resources, the driving forces for economic growth.

However, such high and rapid economic growth and growth of TFP did not last. In 1995-2001, the economic growth rate (8.2 percent) was lower than the long-term potential growth rate (9.3-9.5 percent). And since 1995, the sources for China's economic growth changed substantially.

First, employment growth dropped significantly (only 1.2 percent). This indicates that the ability of the economy to absorb labor has weakened, leaving China in the state of high economic growth but low employment growth.

Secondly, the capital stock growth rate was 2.5 percentage points higher than that in 1978-1995 and also higher than the growth of 11.5 percent in 1952-1978. 
Capital productivity (economic growth minus capital growth) turned from positive $(0.5$ percent) to negative ( -3.6 percent). In terms of capital deepening, the per labor capital growth was as high as 10.6 percent, which is the fastest in the world and also the fastest capital deepening process, nearly 4 percentage points higher than in 1978-1995.

Thirdly, the human capital growth rate was as high as 2.8 percent. During this period, more students were enrolled in senior middle schools and institutions of higher learning in China. China has become the country with the largest number of tertiary school students.

Fourthly, TFP dropped significantly to $0.3-2.3$ percent (calculated by different weights assigned to capital and labor), dropping by $2-3$ percentage points. This shows that the main source for economic growth in 1995-2001 was high capital input, low labor input, and low productivity.

What merits attention is the economic situation in 2003, when GDP growth was 9.1 percent, which is close to the long-term potential growth rate. The investment growth rate was 26.7 percent, much higher than the average growth (10.9 percent) in 1979-2001. Investment was apparently heating up. According to the author's estimates, the capital stock growth in 2003 was 15.8 percent (after accounting for depreciation) and its contribution to economic growth was about 6.3-9.5 percent (calculated by the weights assigned to capital and labor). TFP dropped to 1.1 to -1.1 percent. It was estimated that the contribution of TFP to economic growth in 2003 was likely to be negative, similar to the time when the planned economy prevailed. This shows that although economic growth in 2003 reached the potential growth rate, overheated investment appeared. The investment growth rate was far higher than the economic growth rate. This probably will have a positive investment effect, but more importantly it lowers capital productivity, probably to -6.7 percent. Economic growth was far lower than capital stock growth, thus greatly reducing the growth of TFP.

I am concerned about a possible reverse in the process of the transition of economic growth model - reversing to the growth pattern from high-quality, high-efficiency, low-energy consumption and low-pollution emission to lowquality, low-efficiency, high-energy consumption and high-pollution emission.

\section{Five major effects that drive China's rapid economic growth}

Factors determining economic growth have two different effects. The first is what we call the "horizontal effect," which refers to a short-term growth effect of capital input under conditions in which technological progress and industrial structures remain unchanged. As long as capital input is increasing, the economic growth level will rise. The second is the "speed effect," which means that technological progress, industrial restructuring, and changes in economic organizations will generate long-term growth. The horizontal effect has a role to play only in the short term. The speed effect, however, plays a role in long-term growth. The speed effect plays the fundamental role in the economic growth of a country. Since reform, China's economy has grown in a sustained manner, 
exhibiting the speed effect. In fact, five major effects which are interrelated and interact have contributed to the high-speed economic growth for the past quarter of a century.

The first effect is the speed effect, i.e., in a given period of time, the industrialization latecomers achieve a higher economic growth than the forerunners. China has been experiencing the fifth catching-up in modern history at a higher growth rate than the prior four catching-ups (see Table 1.1). If we say that the "four little dragons" in East Asia experienced thirty years of high-speed growth after World War II, the highest and the longest lasting growth among lessadvanced countries since industrial revolution, and achieved the "East Asian miracle," China, once again, broke the record. More significantly, this time the "the miracle" has happened in a country that has one-fifth of the world total population. ${ }^{11}$

Mankul Orsen discovered from the economic growth data of the nineteenth and twentieth centuries that a poor country may achieve the highest economic growth and the growth rate would increase with the passing of time. In the 1980s and 1990s, China's economic growth ranked the second and the first among 174 economies in the world. If we compare the 1870 s and 1880 s with the 1970s, 1980s and 1990s, the four fastest growing economies in the earlier period often showed faster growth than the four fastest growing economies during the late period (see Table 1.4).

The structure effect shows that, in a given period of time, the structural indicator of latecomers changes faster than advanced countries. For example, it took Japan eighty years to reduce the percentage of its agricultural labor in the total employment from 70 percent to 50 percent. It took the United States fifty years (in 1820-1870), the former Soviet Union/Russia thirty-three years (from 1917 to 1950) and China only seventeen years (from 1978 to 1995) to achieve the same. The period of 1978-2003 witnessed major changes in the structures of population, employment, production, demand, consumption and trade, with eleven of the sixteen indicators exceeding the changes in 1952-1978 (see Table 1.9). Accelerated growth may stimulate labor to move to the high-level production sectors, and structural changes constitute an important source of economic growth, as the movement of labor from low productivity sectors to the high productivity sectors is always accompanied by the growth of material capital stock, the improvement in the skills of workers, the development of education, organizational improvements, and more openness in international trade.

The opening up effect, that is, the participation of industrially less developed economies in globalization, is faster than in advanced countries. According to calculations by Maddison, exports made up only 1 percent of the world total output in 1820 and rose to 8.7 percent by 1913 and further up to 13.5 percent by 1992. The economic takeoff of a country is inevitably accompanied with the rapid rise in total and unit international trade. The share of exports in total GDP of all countries that have achieved economic catch-up rose significantly. This has been proven by Japan, the ROK, Thailand and Taiwan. China began to open up toward the end of the $1970 \mathrm{~s}$, transiting from an isolated model that 
Table 1.9 China's economic structural changes (1952-2003) (\%)

\begin{tabular}{|c|c|c|c|c|c|}
\hline Indicator & 1952 & 1978 & 2003 & $\begin{array}{l}\text { Average } \\
\text { annual } \\
\text { change } \\
1952-1978\end{array}$ & $\begin{array}{l}\text { Average } \\
\text { annual } \\
\text { change } \\
\text { 1978-2003 }\end{array}$ \\
\hline
\end{tabular}

Population structure (total)

$\begin{array}{lrrrrr}\text { Urban population } & 12.5 & 17.9 & 40.5 & 0.21 & 0.90 \\ \text { Rural population } & 87.5 & 82.1 & 59.5 & -0.21 & -0.90\end{array}$

Employment structure (total employed population)

$\begin{array}{lccccr}\text { Primary industry } & 83.5 & 70.5 & 49.1 & -0.5 & -0.86 \\ \text { Secondary industry } & 7.4 & 17.3 & 21.6 & 0.38 & 0.17 \\ \text { Tertiary industry } & 9.1 & 12.2 & 29.3 & 0.12 & 0.68\end{array}$

Production structure (GDP by production approach)

$\begin{array}{lrrrrr}\text { Primary industry } & 50.5 & 28.1 & 14.6 & -0.86 & -0.54 \\ \text { Secondary industry } & 20.9 & 48.2 & 52.3 & 1.05 & 0.16 \\ \text { Tertiary industry } & 28.6 & 23.7 & 33.1 & -0.19 & 0.38\end{array}$

Domestic demand structure (GDP by expenditure approach)

$\begin{array}{lccccr}\text { Household consumption } & 65.4 & 48.8 & 43.2 & -0.64 & -0.22 \\ \text { Government consumption } & 13.5 & 13.3 & 12.2 & -0.008 & -0.04 \\ \text { Capital formation } & 22.2 & 38.2 & 42.9 & 0.62 & 0.19 \\ \text { Net export } & -1.1 & -0.3 & 1.8 & 0.03 & 0.08\end{array}$

Household consumption structure (Engel coefficient)

\begin{tabular}{|c|c|c|c|c|c|}
\hline Cities and towns & & 57.5 & 37.1 & & -0.82 \\
\hline Rural areas & & 67.7 & 45.6 & & -0.88 \\
\hline \multicolumn{6}{|c|}{ Trade ratio (\% of GDP) } \\
\hline Export & 4.0 & 4.6 & 31.1 & 0.02 & 1.06 \\
\hline Import & 5.5 & 5.2 & 29.3 & -0.01 & 0.96 \\
\hline
\end{tabular}

Sources: Guojia tongjiju (National Statistical Bureau of China), Xinzhongguo wushinian tongji ziliao huibian (Collection of Statistical Data of the 50 years of New China), Beijing: Zhongguo tongji chubanshe (China Statistics Press), 1999, pp. 1-3, p.60; Guojia tongjiju (National Statistical Bureau of China), Zhongguo tongji zhaiyao 2004 (China Statistical Abstract 2004), Beijing: Zhongguo tongji chubanshe (China Statistics Press), 2004, pp. 16, 37, 41, 98, 158.

was completely cut off from the world economically to a social development model that partially opened up to the rest of the world. The total import and export value in 1978 was US \$20.6 billion, accounting for 13 percent of GDP. But by 2003 , it topped US $\$ 850$ billion, 41 times that of 1978 , accounting for 60.3 percent of GDP. ${ }^{12}$ It was only 0.66 percent in 1975 , but it quadrupled to 1.44 percent and reached 4.56 percent by 2002 and was likely to top 5 percent by 2003 . China has become the fourth largest exporter in the world. This marks the transition from a partially open society to a fully open society.

China has caught up with the level of the world great powers from being a country of autarchy. But about half of China's exports are goods processed with imported materials. If such processing trade is deducted, the opening up of a country like China is still far lower than the global level. ${ }^{13}$ Since reform, not 
only have China's exports grown rapidly, but the export product mix has also undergone tremendous changes. In 1980, China's primary product exports made up 50.2 percent of the total exports, but by 1985 , the percentage dropped to 35.0 percent and further went down to 14.6 percent by 1990. By 2000, it plummeted to 4.7 percent. In the meantime, exports of manufactured goods rose, reaching 87.1 percent of total exports by 2000 . The proportion of high-technology exports of total exports rose from 2.6 percent to 22.4 percent. The export volume of all products in world total exports also rose steadily. The proportion of low technological products rose from 4.5 percent in 1985 to 18.7 percent by 2000 . The proportion of high-technology products rose from 0.4 percent to 6.0 percent by 2000 . This shows that China has exploited its advantages in both laborintensive products export and in the export of high-technology products (see Table 1.10).

The institutional effect, that is, the degree of liberalization, has improved significantly and the economic operation has been based on the market mechanism. Where is China in terms of orienting its national economy toward a market economy after twenty-four years of efforts, from 1978 to 2002 ? How far has China gone in its market-oriented reform during that same period? The experience of China's reform and opening up shows that the reform is a process in which market mechanisms have played an increasingly large role in the allocation of resources, and the dependency on market mechanisms has been deepened and enhanced. This includes the establishment and improvement of the market infrastructure, the establishment and implementation of institutional market rules and the standardization of the behaviors of market players. Based

Table 1.10 Export competitiveness of China in world trade (1985-2000) (\%)

\begin{tabular}{lrrrr}
\hline Item & 1985 & 1990 & 1995 & \multicolumn{1}{c}{2000} \\
\hline Share of world market & 1.6 & 1.8 & 4.8 & 6.1 \\
Primary products & 2.4 & 2.6 & 2.5 & 2.3 \\
Resources products & 1.1 & 1.3 & 2.1 & 2.7 \\
Non-resources manufactured products & 1.5 & 3.4 & 6.1 & 7.8 \\
Low technology & 4.5 & 9.1 & 15.5 & 18.7 \\
Middle grade technology & 0.4 & 1.4 & 2.6 & 3.6 \\
High technology & 0.4 & 1.4 & 3.6 & 6.0 \\
Other & 0.7 & 0.7 & 1.4 & 1.8 \\
\% in total exports & 100.0 & 100.0 & 100.0 & 100.0 \\
Primary products & 35.0 & 14.6 & 7.0 & 4.7 \\
Resources products & 13.6 & 8.2 & 7.4 & 6.9 \\
Non-resources manufactured goods & 50.0 & 76.2 & 84.6 & 87.1 \\
Low technology & 39.7 & 53.6 & 53.5 & 47.6 \\
Middle grade technology & 7.7 & 15.4 & 16.9 & 17.3 \\
High technology & 2.6 & 7.3 & 14.2 & 22.4 \\
Other & 1.4 & 0.8 & 1.0 & 1.1 \\
\hline
\end{tabular}

Source: UNCTAD, World Investment Report 2002: Transnational Corporations and Export Competitiveness, New York: United Nations, 2002. 
on this understanding, we have selected nine areas and designed twenty-four indicators to measure the degree of market evolution and liberalization in all aspects. ${ }^{14}$ These indicators reflect from different angles the features of the market (see Table 1.11 and Figure 1.2):

- Study of the adaptability of government behaviors to the market (including the behavior, the scale and ways of participation of the government, how far the government has withdrawn from the microeconomic area and how far it has realized the transition from direct to indirect macroeconomic control and the methods and changes in the abilities of the government to accumulate revenue);

- Manifestation of the market in the economic structure including income distribution, industrial output and distribution of consumer goods;

- Competitiveness of price and market (changes in the commodity consumption by peasants and the deepening of the role of market demand and supply in price formation);

- Market orientation of investment (non-state investment and changes in the ownership of investment);

- Market orientation of banking and insurance (including changes in the ownership of banks and the accommodation of negotiable securities);

- International level of the economy and openness (including dependency on trade, dependency on production and tariff levels);

- Market orientation of production factors (including the structure of ownership of the labor market in urban areas and towns and the shrinkage of the rural natural economy);

- Adaptability of the environment for the operation of the economic system to the market evolution (including the evolution of education and human capital input mechanisms, public welfare and social relief);

- Rules and the legal system (including the accumulation of legal factors, evolution of the legal system for the economy and the enhancement and popularization or diffusion of the rule of law among economic players).

Technology catch-up effect refers to the rate of technology diffusion of technologically lagging countries $\left(\mathrm{T}_{2}\right)$ evidently higher than the technological innovation speed of technologically advanced countries $\left(\mathrm{T}_{1}\right)$, that is, $\mathrm{T}_{2}>\mathrm{T}_{1}$, revealing the features of technology catch-up. This is because the cost of technology innovation is higher than the cost of technology imports and the time required to achieve commercial application of technological innovation is longer than that required by using technological imports. Although developing countries are less developed in technology, technological imports may lower the cost of innovation, thus shortening the time for new products to enter the market. Technological innovation is mainly manifested in new products and new markets. When it refers to the technology innovation of less developed countries in technology ( $\mathrm{t}$ ), it may accelerate the pace of technological catch-up, that is, $\mathrm{T}_{2}+\mathrm{t}$ $>\mathrm{T}_{1}$. It is exactly these two conditions that have made it possible for less- 
Table 1.11 Evolution of the marketization development indicators (MDI) of the entire and local economic operational mechanism of China (1978-1999) (\%)

\begin{tabular}{|c|c|c|c|c|c|c|c|c|c|c|}
\hline Year & $\begin{array}{l}\text { Changes } \\
\text { of } \\
\text { govern- } \\
\text { ment } \\
\text { behavior } \\
\text { (10.0) }\end{array}$ & $\begin{array}{l}\text { Market- } \\
\text { ization } \\
\text { of outpu } \\
\text { and } \\
\text { distribu- } \\
\text { tion } \\
\text { (11.7) }\end{array}$ & $\begin{array}{l}\text { Market- } \\
\text { ization } \\
\text { tof price } \\
\text { and } \\
\text { trading } \\
(10.6)\end{array}$ & $\begin{array}{l}\text { Market- } \\
\text { ization } \\
\text { of } \\
\text { invest- } \\
\text { ment } \\
(10.3)\end{array}$ & $\begin{array}{l}\text { Market- } \\
\text { ization } \\
\text { of } \\
\text { banking } \\
\text { and } \\
\text { insur- } \\
\text { ance } \\
(9.7)\end{array}$ & $\begin{array}{l}\text { Market- } \\
\text { ization } \\
\text { of } \\
\text { foreign } \\
\text { trade } \\
(11.2)\end{array}$ & $\begin{array}{l}\text { Market- } \\
\text { ization } \\
\text { of labor } \\
\text { and } \\
\text { employ- } \\
\text { ment } \\
(12.1)\end{array}$ & $\begin{array}{l}\text { Market } \\
\text { opera- } \\
\text { tional } \\
\text { environ- } \\
\text { ment } \\
(12.4)\end{array}$ & $\begin{array}{l}\text { Rules } \\
\text { and } \\
\text { legal } \\
\text { system } \\
(12.0)\end{array}$ & $\begin{array}{l}M D I \\
\text { (a) }\end{array}$ \\
\hline 78 & .54 & 24.98 & 24.33 & 13.80 & 0.94 & 10.60 & 16.16 & 5.03 & 3.78 & 18.3 \\
\hline 79 & 71.08 & 25.12 & 28.76 & 19.03 & 0.99 & 13.14 & 16.85 & 5.51 & 5.15 & 19.9 \\
\hline 80 & 72.26 & 27.23 & 34.69 & 28.51 & 1.14 & 14.28 & 17.60 & 6.51 & 4.79 & 2.25 \\
\hline 81 & 74.13 & 31.33 & 38.98 & 30.57 & 1.49 & 15.90 & 17. & 7.53 & 5.21 & 24.02 \\
\hline 82 & 74.24 & 34.97 & 39.56 & 38.15 & 1.47 & 16.25 & 18.06 & 8.74 & 5.72 & 5.56 \\
\hline 83 & 75.70 & 39.08 & 41.82 & 48. & 1.63 & 16 & 19.14 & 10.03 & 3.91 & 27.64 \\
\hline 84 & 75.25 & 43.89 & 46.25 & 49. & 2.34 & 18 & 23.16 & 1 & 5.33 & 29.80 \\
\hline 8 & 73.24 & 55.74 & 62.17 & 49.1 & 1.91 & 22.22 & 24.28 & 12.91 & 7.44 & 33.60 \\
\hline 86 & 74.98 & 57.89 & 62.74 & 48.89 & 1.97 & 26.09 & 25.14 & 14.25 & 7.47 & 34.78 \\
\hline 987 & 74.48 & 59.49 & 65.90 & 49.71 & 2.14 & 28.21 & 25.77 & 15.44 & 9.07 & 36.00 \\
\hline 98 & 74.44 & 61.06 & 69.89 & 53.34 & 3.25 & 28.56 & 26.14 & 16.46 & 0.66 & 37.49 \\
\hline 98 & 73.15 & 61.79 & 64.41 & 50.37 & 2.98 & 26.66 & 25.63 & 17.98 & 11.35 & 36.53 \\
\hline 1990 & 73.83 & 61.04 & 69.45 & 52.80 & 2.85 & 34.79 & 29.55 & 18.44 & 9.65 & 38.52 \\
\hline 1991 & 73.18 & 60.01 & 67.65 & 51.66 & 2.95 & 39.37 & 29.29 & 19.14 & 10.51 & 38.71 \\
\hline 199 & 73.51 & 61.72 & 69.30 & 51.83 & 4.43 & 43.06 & 29.96 & 21.43 & 11.23 & 40.14 \\
\hline 199 & 79.86 & 65.61 & 75.59 & 56.09 & 8.84 & 41.15 & 31.82 & 22.77 & 13.65 & 43.23 \\
\hline 199 & 80.36 & 69.59 & 71.53 & 59.09 & 9.18 & 59.82 & 33.42 & 23.74 & 13.87 & 46.09 \\
\hline 199 & 81.82 & 71.77 & 72.10 & 61.03 & 827 & 58 & 35.11 & 25.87 & 15.69 & 47.16 \\
\hline o & 80.79 & 71.68 & 73.73 & 62.70 & 10.58 & 54.18 & 36.52 & 27.10 & 15.14 & 47.43 \\
\hline 199 & 8264 & 74.85 & 74.83 & 62.76 & 19.97 & 56.09 & 37.91 & 28.96 & 19.48 & 50.15 \\
\hline 100 & 8270 & 76.30 & 75.51 & 61.63 & 17.12 & 54.90 & 43.49 & 31.72 & 18.44 & 50.78 \\
\hline 1999 & 82.98 & 77.23 & 76.86 & 60.43 & 18.97 & 44.26 & 45.04 & 33.43 & 17.92 & 50.25 \\
\hline
\end{tabular}

Source: Wu Qungang, "Impact of Institutional Changes on Long-Term Economic Performance: Theories, Models and Application," doctoral dissertation at School of Economics and Management of Tsinghua University under the supervision of Dr. Hu Angang, 2002.

Notes: (a) MDI is the weighted sum of nine indicators. Data in brackets are weights. All calculations are completed by SPSS10.0 software.

advanced countries to realize technology catch-up, hence raising their labor productivity, which in turn stimulates economic catch-up, narrowing the gap with developed countries. The history of world economic development shows that Japan and the Asian "four little dragons" are fairly successful examples. China, India, and Southeast Asian countries are becoming successful paradigms of the second generation of industrialized countries.

But where does China's technology come from? There are three sources according to the calculation by the value method.

One is direct imports or import of capital goods containing new technologies, such as import of high-technology products. But the technology imports do not include spending on medium and high technology transfer, copyright, 


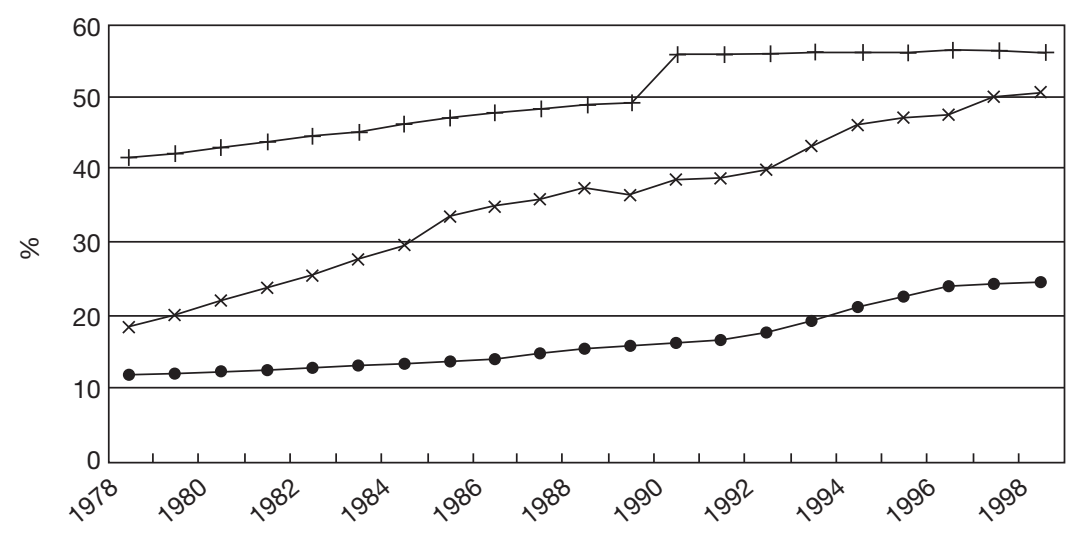

$\rightarrow$ Labor participation $\quad *$ Institutional cumulation $\quad \rightarrow-$ Knowledge cumulation

Figure 1.2 Changes of China's labor participation, institution, and knowledge indicators (1978-1998)

Source: Xiong, Yi zhishi wei jichu de fazhan zhanlue yanjiu.

and patent fees. The second is direct acquisition of new technologies through foreign direct investment (FDI), though FDI is not entirely used in R\&D. The third is direct financing of Chinese enterprises and institutional innovation by spending on $R \& D$, which is expressed in the proportion of national $R \& D$ in GDP. Together, the total spending on R\&D as a share of GDP rose from 4.10 percent in 1991 to 10.36 percent in 2001 (see Table 1.12).

China also obtains and disseminates knowledge, technology, and information through telecom networks and the Internet, and obtains new knowledge and new technologies through science and technological cooperation with advanced countries, exchanges in science and technology and exchanges of personnel. But these cannot be quantitatively measured.

The other method is the knowledge accumulation indicator, which is made up of ten indicators. ${ }^{15}$ Since reform, China's knowledge development indicators have grown in a sustainable manner and China has become one of the fastest growing countries in terms of knowledge development. The knowledge accumulation indicator in China grew by 108 percent from 12.22 in 1980 to 25.70 in 2000 . However, it is still short of the 185 percent growth in ROK and greatly lagging behind the United States, Britain and Japan. China is still a knowledge importer and consumer rather than a knowledge innovator (see Table 1.13).

The entire process of catching up with developed countries is a process of economic and knowledge catching up, with the knowledge growth and economic growth mutually reinforcing each other and mutually supplementing each other. In the future, China should transit from a capital-driven economy to a technologydriven economy. 
Table 1.12 China's technology sources (1991-2001)

\begin{tabular}{llllllr}
\hline Year & $\begin{array}{l}\text { Import of } \\
\text { high } \\
\text { technology } \\
\text { (million } \\
\text { US \$) }\end{array}$ & $\begin{array}{l}\text { FDI } \\
\text { (million } \$)\end{array}$ & $\begin{array}{l}\text { Total } \\
\text { technology } \\
\text { sources } \\
\text { (million } \\
\text { US \$) (c) }\end{array}$ & $\begin{array}{l}\text { \% Total } \\
\text { technology } \\
\text { sources in } \\
\text { GDP (d) }\end{array}$ & $\begin{array}{l}\text { \%of } \\
\text { spending } \\
\text { on R\&D } \\
\text { in GDP } \\
(\text { e) }\end{array}$ & $\begin{array}{l}\text { Total in } \\
\text { GDP }(f)\end{array}$ \\
\hline 1991 & 94.39 & 43.66 & 138.05 & 3.40 & 0.70 & 4.10 \\
1992 & 107.12 & 110.37 & 217.49 & 4.50 & 0.79 & 5.29 \\
1993 & 159.09 & 275.15 & 434.24 & 7.22 & 0.74 & 7.96 \\
1994 & 205.95 & 337.67 & 543.62 & 10.02 & 0.66 & 10.68 \\
1995 & 218.27 & 357.21 & 575.48 & 9.84 & 0.60 & 10.44 \\
1996 & 224.69 & 417.25 & 641.94 & 7.86 & 0.60 & 8.46 \\
1997 & 238.93 & 452.57 & 691.50 & 7.70 & 0.64 & 8.34 \\
1998 & 292.01 & 454.63 & 746.64 & 7.89 & 0.69 & 8.58 \\
1999 & 375.98 & 403.19 & 779.17 & 7.86 & 0.83 & 8.69 \\
2000 & 540 (a) & 407.15 & 947.15 & 8.76 & 1.00 & 9.76 \\
2001 & 621 (a) & 468.78 & 1090 & 9.27 & 1.07 & 10.34 \\
\hline
\end{tabular}

Sources: (a) Estimates by author; data for technology import from Ministry of Science and Technology. See Zhongguo kexue jishu zhibiao 2000 (China Science and Technology Indicators 2000), Beijing: Science and Technology Literature Press, 2000, p. 198; FDI from Guojia tongjiju, Zhongguo tongji nianjian 2002 (China Statistical Yearbook 2002), Beijing: Zhongguo tongji chubanshe, 2002, p. 629; R\&D spending in GDP from Zhongguo tongji nianjian 1999 (China Statistical Yearbook 1999), Beijing: Zhongguo tongji chubanshe, 1999, p. 675 and Zhongguo tongji nianjian 2002, p. 703.

Notes:

1. Technology import includes high-technology import and FDI, not including imports that do not contain technology.

2. Total technology sources $=$ Import of high technology + FDI; Total in GDP $(\mathrm{f}=\%)$ total technology sources in GDP $+\%$ of spending on R\&D in GDP.

Table 1.13 International comparison of the knowledge development indicator (KDI) (1980-2000)

\begin{tabular}{lrrrrrl}
\hline Country & 1980 & 1985 & 1990 & 1995 & 2000 & $\begin{array}{l}\text { Growth } \\
\text { indicator } \\
(1980=1)\end{array}$ \\
\hline Brazil & 12.61 & 13.85 & 14.49 & 16.73 & 26.27 & 2.08 \\
China & 12.22 & 13.79 & 16.25 & 22.56 & 25.70 & 2.10 \\
Chinese Hong Kong & 22.90 & 24.74 & 29.21 & 34.04 & 46.03 & 2.01 \\
India & 9.28 & 10.68 & 11.86 & 13.43 & 15.04 & 1.62 \\
Japan & 43.57 & 45.13 & 47.03 & 51.44 & 62.27 & 1.43 \\
ROK & 21.91 & 27.19 & 32.90 & 46.69 & 62.39 & 2.85 \\
Britain & 38.74 & 41.35 & 45.44 & 50.70 & 65.93 & 1.70 \\
US & 47.52 & 48.63 & 55.92 & 60.38 & 69.82 & 1.47 \\
\hline
\end{tabular}

Source: Xiong, Yi zhishi wei jichu de fazhan zhanlue yanjiu. 


\section{Challenges China faces in economic development}

China's development has attracted worldwide attention. On the one hand, China's development speed startled the world, which called it "the China miracle" or "the rise of modern China." On the other hand, it has made people wonder whether or not China's development can be sustained. What are the challenges, development bottlenecks or other factors constraining its potential development in the next decade? Should these factors appear (individually or combined), what impacts will they have on China's economic performance?

Generally speaking, China is facing six major challenges:

\section{Increasingly large gaps between urban and rural}

One of the basic national conditions of China is "one country, two systems." This does not refer to the idea introduced when China recovered the sovereignty of Hong Kong and Macao. It refers to the two different institutional arrangements of cities and the countryside in the Chinese mainland. The basic conflict in Chinese society is the contradiction between the dual economic and social structures in the cities and the countryside. The urban/rural gap has become one of the biggest challenges to China's development. It is also the biggest institutional obstacle to furthering productivity and social progress. The urban/rural gap mainly manifests itself in the following ways: (1) income gap; (2) consumer spending gap: If all the financial subsidies to urban residents are converted, the real gap in consumption level between urban and rural residents is six times; (3) public service gap: A large number of ill-educated people live in the rural areas, especially in the rural areas of the western part of China. The inequality of educational resources between urban and rural areas is extremely large and there are huge gaps between urban and rural areas in terms of the distribution of public health resources, medical insurance coverage, telecom and postal services; (4) labor productivity gap: The percentage of agricultural output value in GDP has dropped, and the proportion of agricultural labor productivity to national average labor productivity has also dropped. The proportion of per capita income of peasants to per capita GDP and the proportion of peasants' income from farming to their total income has also declined. ${ }^{16}$

\section{Enlarging regional gaps}

China is a country with the biggest regional disparities in the world. It is known as "one China, four worlds." The first world covers high-income areas, which include Shanghai, Beijing and Shenzhen, with a total population accounting for only 2.2 percent of the national total; the second world covers middle-income areas, including Tianjin, Guangdong, Zhejiang and Jiangsu, with a population accounting for 21.8 percent of the national total; the third world refers to lower middle income areas, with a population accounting for 26 percent of the national 
total; and the fourth world refers to low income areas, mainly poor areas in the middle and western parts of the country, with a population accounting for 50 percent of the national total. The gap is seen not only in per capita income or per capita GDP but also in economic and social indicators. About half of the population is still in the low income group. The per capita national income, a key indicator of economic development, shows that China has already attained the level of a well-off society, that is, the lower-middle income level in the world. But it is extremely uneven.

\section{Uneven economic and social development}

Although China has realized the goal of quadrupling its GDP and per capita GDP by 2000 ahead of schedule, it failed to achieve the important social development goal of "primary health service to all" by 2000 . China's human development indicator growth is lower than other populous developing countries. ${ }^{17}$

\section{Incompatibility of investment in hardware and software}

China's domestic investment rate is fairly high compared with the level of the world, about 40 percent. But government spending on public education, infrastructure and poverty relief is gravely inadequate, with its proportion in GDP lower than the world average.

In economic development, the government, especially local governments, often over-involve themselves and become major interest groups. They not only deeply involve themselves in economic activities, but also seek profits. Thus, there are temptations to launching big projects, making investments blindly and building similar projects again and again. However, in the social development areas, the government is often absent. The supply of public goods is inadequate, public services are not in place, and services are beyond the reach of most people and low in quality. Public service supply is biased toward cities. There is neither efficiency nor equality.

Economic wealth has grown rapidly and social costs have risen drastically. Even calculated according to constant price, GDP in 2002 was 8.5 times that of 1978. The individual assets of urban residents (bank savings alone reached 8700 billion Yuan by the end of 2002) have also increased, but social costs and deficits have become larger and larger and the society has become more and more insecure. There are increasing tensions between labor and management, between labor and enterprises. The number of recorded disputes and conflicts is on an upward trend. The social order has become seriously damaged. Crimes and security related incidents have become serious, aggravating social problems. Traffic accidents, fires, work injuries and worksite accidents occur frequently. Corruption cases have grown in number. The number of all kinds of offenses has risen rapidly. The amount of money involved in these cases has reached 7.2 percent of the total GDP. 


\section{The imbalance between resources and environment on the one hand and development on the other}

The basic characteristics of the national condition of resources in China can be described as large in territory and abundant in resources in aggregate, but on a per capita basis, the amount of resources is very small, and the space for subsistence is very narrow. In terms of resource supplies relative to development demand, there are shortages in many resources and the situation is getting worse. The environmental and ecological problems include worsening soil erosion and water loss. The desertification of land is growing. China is one of the countries with the worst desertification problem. The desertification areas have reached 2.62 million square kilometers, which is 27 percent of the total land area, and the land becomes desertified by an average of 2460 square kilometers every year. The standing stock of forests has dropped drastically. China is one of the countries that have the least forests, with a total forest area accounting for 3.9 percent of the world total and the standing stock of forests accounting for 2.5 percent of the world total. The forest coverage is only 14 percent as opposed to 55.4 percent in Russia. The per capita standing stock of forests is less than 19 cubic meters, accounting for 13 percent of the world's per capita average. China's ecological deficit is mainly manifested in the forest deficit. Most of the state-owned forest enterprises have no mature forests to log. Grassland degeneration, desertification and salination have been increasing year by year. Air pollution is very serious and acid rain is affecting increasingly large areas. China is both a large energy consumer and a large polluter. If the energy consumption trend continues, China will become one of the countries with the biggest greenhouse gas emissions in the first half of the twenty-first century. ${ }^{18}$ Water pollution is becoming more and more serious, thus worsening an already serious shortage of water resources.

The deterioration of the ecological environment has exacerbated natural disasters, which have shot up, with more and more areas becoming prone to natural disasters. The economic costs caused by natural disasters in the 1990s accounted for 3 to 5 percent of the GDP. Air and water pollution have also caused losses in human capital and economy. Further, some costs of ecological damage are hard to calculate, such as forest logging, grassland degeneration, water loss and soil erosion, desertification, river runoff reduction, shrinkage of lake surfaces, damages to all kinds of mineral sources and sharp reduction in cultivated land - all of these can cause big losses and overwrite the GDP increment.

\section{Imbalance between economic growth and employment growth}

China is the most populous country in the world. Its population makes up 21.3 percent of the world total population. China also has the largest working population. In 1999, the population aged 15-64 was 844 million, 22.4 percent of the world total. The working population (referring to the employed population and active servicemen) was 751 million, 25.9 percent of the world total. ${ }^{19}$ China 
is, therefore, a country with abundant labor, but also a country with the biggest employment pressures. In the 1990s, China's economic growth pattern began to transit from high employment growth to low employment growth, with the per capita capital output assuming a downward trend.

The new generation of Chinese leaders is well aware of these challenges and their negative effects. In February 2004, Premier Wen Jiabao pointed out that China has achieved rapid economic development but also accumulated a few problems, which mainly include the urban/rural gap, regional disparity and income gaps among residents. These gaps are continuing to enlarge; the pressure of employment and social security is mounting; education, public health, culture and other social undertakings are lagging behind; the conflict between population growth and economic development on the one hand and the ecological environment and natural resources on the other has been exacerbating; the economic growth pattern is backwards; and the quality of the economy as a whole is not high and lacks competitiveness. These problems demand our full attention. They must be resolved step by step and under no circumstances should they be allowed to run their own course. So Wen Jiabao put forth a development approach of "putting people first" that advocates sustainable development. ${ }^{20}$

\section{Take up all major challenges and foster a new approach to development}

Since the founding of the People's Republic of China, we have implemented two generations of economic development strategies. The first generation was the traditional economic development strategy during the period of planned economy. In the mid-1950s, Mao Zedong put forward the strategic conception of "catch-up with Britain and the United States." In the mid-1960s, he put forward the strategic conception of "Four Modernizations" by the end of the century, introducing "high accumulation, low consumption" policies, giving priorities to the development of heavy industries, including the military industry, adopting capital-intensive guidelines and highly protective import substitution policies. This resulted in a highly conflicted urban-rural dual system.

The second generation of development strategies occurred during the transition period. In the 1980 s, Deng Xiaoping put forth the idea of a three-step development. The goal of quadrupling the GDP was achieved ahead of schedule. The country made the best use of its comparative advantages in labor resources and pursued an opening-up policy. The policy stimulated export growth and realized a liberalization of trade and investment. The country also introduced market mechanisms and encouraged market competition. This strategy agreed with the national condition of China and accelerated the economic and social development and narrowed the gap with developed countries. But still, the strategy was material-centered, with the pursuit of high-speed economic growth as the primary goal. What Deng Xiaoping advocated was "high-speed development" and "uneven development," allowing some areas and part of the population to get rich first. But high-speed economic growth was achieved at 
the price of high capital input, high energy consumption and heavy pollution. Concomitant with development was an enlarged urban/rural income gap, a regional development gap and the biggest inequality (Gini coefficient) in the world in terms of the income distribution among residents.

Now, Chairman Hu Jintao and Premier Wen Jiabao have put forth the third generation of development strategies, which features harmonious, sustainable development and common prosperity. In fact, the fifth plenary session of the Fourteenth National Party Congress in 1995 already put forth the principle of "coordinated regional development to narrow the regional gaps." In June 1999, Jiang Zemin put forth the "Western China Development" strategy and began to officially implement the strategy in 2001. This also falls in line with coordinated regional development. The Party's Sixteenth National Congress officially put forward the development goal of building a well-off society that will benefit the entire population and defined it as "greater economic development, sounder democracy, greater progress in science and education, more flourishing culture, greater social harmony and much improved life of the people." At an expert forum on June 17, 2003, Wen Jiabao clearly put forward the approach of coordinated development in four aspects, namely, coordinated development of both urban and rural areas; coordinated development among different regions; coordinated social and economic development; and coordinated development between man and nature. ${ }^{21}$

What development strategies should China adopt to cope with the major development challenges?

First of all, it is imperative to achieve urban/rural coordinated development to narrow the enlarging gaps. The first and foremost problem in development is always the problem of peasants. The first and foremost task of China's development is to transfer peasants by removing institutional barriers and accelerating the pace of urbanization. China needs an institutional revolution of liberating the peasants so as to eliminate at its roots the unequal and unfair situation of isolation, opposition and separation of urban and rural areas. The aim is to free the peasants, invest in the peasants, serve the peasants, transfer the peasants, reduce the number of peasants and make the peasants rich. The state should set up a standard transfer payments system in the rural areas and provide the rural population with basic public services. The state should invest in the rural infrastructure, improve the production and living conditions of rural areas and create more employment opportunities for peasants. ${ }^{22}$

Secondly, it is imperative to launch western China's development initiatives and to revitalize the old industrial bases in northeast China so as to narrow the gap between the east and the west and between the south and the north, that is, the development gap between southeast coastal areas and the northeast China area. It is essential to establish a unified and fair domestic market and to promote the free movement of all production factors, especially the movement of labor. It is also essential to accelerate the pace of urbanization to make the urban population exceed that of the rural areas. Only then will it be possible for China to narrow the urban/rural gap and the regional development gap. 
Thirdly, it is necessary to promote a "two-wheel drive" in order to solve the imbalance in economic and social development. Economic development is the base for social progress while social progress is the aim of economic development. The two may be compared to "two wheels" that drive the development of human society. The two must be mutually coordinated, and go together. This includes both contemporary development and sustainable development of future generations. It includes both the idea of allowing part of the regions and part of the population to get rich first and the idea of the people in poor areas or at a low level of living standards to enjoy the fruits of social development. It includes both the narrowing of economic gaps and the social development gaps to realize the equalization of basic public services for the people of the whole country. Basic public services, such as education, health, family planning, environmental protection and infrastructure, must meet the minimum demands of all people. The goals of enabling most of the people to live a well-off life and lifting most of the poor population out of poverty are equally important. Only when there is equal service will it be possible to have the most efficient service. It is, therefore, essential to display the leading role of the government in social development. The government should increase its investment in "social software" and reduce investment in hardware so as to make the two kinds of investment well matched. It is essential to shift the emphasis of investment from large-scale public investment (infrastructure) to providing public services, and from materials to human resources.

Fourthly, we should improve the ecological environment and attain "green development." The environment is one of the three major assets for economic development. "Green development" is an inevitable path of development. This stresses unified and harmonized economic development and environmental protection, a path toward sustainable development that puts the people first. Large cities must become "green cities" instead of "black cities;" agriculture must become green agriculture instead of black agriculture; green GDP should be used. The fundamental way out for solving the problem of the deterioration of the ecological environment is to change the economic growth pattern, to follow a new path toward sustainable economic development, the never-ending utilization of resources, the steady improvement of the environment and a good ecological environment. The core lies in a shift in the pattern of development: from traditional industrialization to new industrialization; from traditional industrial cities to knowledge-intensive, technology-intensive and information-intensive cities; and from high consumption that copies from the West to an appropriate and fair consumption model.

Fifthly, we must give priority to employment and opt for a growth model focused on employment. The number of laborers in China makes up more than one-quarter of the world total work force, equal to 1.6 times that of highincome developed countries, while the capital resources of China are less than 4 percent of the world total. This means that China should opt for an economic growth model that is centered on employment. Creating more jobs should become the first objective of the central and local governments. Employment 


\section{Economic and social transformation in China}

should be the top priority of economic and social policies. The key to changes in the employment growth model, from formal employment to informal, flexible and diversified employment and to build an open society lies in the promotion of the free movement of personnel, labor and the population.

For China, the major challenges in the twenty-first century are not to accelerate growth, but to insure sustainable growth and equity, reduce poverty and promote human development. China should pay attention not only to economic growth, but also to the goal of such growth, namely to meet the increasing material and cultural demand of the over one billion population, including the basic demand for subsistence, especially the population still in poverty, such as food and clothing, employment, education, health and housing, so as to raise the level of human development and enjoy higher standards of living and public services.

The idea of "putting people first" means to invest in the people, serve the people, develop the economy for the people. For human development, the goal is to enhance the development capabilities of the people and increase their development opportunities. The future development model for China should be to lift human development indicators and the standard of living to a fairly high level, and gradually realize common prosperity; to eliminate poverty and prevent polarization; to follow a sustainable development road; to build a resourcessaving national economic system and a living system with an appropriate consumption level. Only then will China's modernization benefit all the people and lead the Chinese people onto the road to common prosperity. 


\title{
2 Comprehensive national power (1980-2000)
}

\author{
A comparative study of the US, \\ Russia, Japan, India and China ${ }^{1}$
}

\begin{abstract}
The art of war is of vital importance to the State. It is a matter of life and death, a road either to safety or to ruin. Hence it is a subject of inquiry which can on no account be neglected. The art of war, then, is governed by five constant factors, to be taken into account in one's deliberations, when seeking to determine the conditions obtained in the field. These are: (1) The Moral Law; (2) Heaven; (3) Earth; (4) The Commander; (5) Method and discipline.
\end{abstract}

(Sun Tze, The Art of War)

Entering into the twenty-first century, economic globalization has been accelerating not only the process of integration of the world economy, but also competition among/between countries, especially among the big powers. International competition manifests itself mainly in dynamic changes in the strategic resources of different countries and open competition between national powers (Zonghe Guoli). They often come into conflict with one another and are locked in contention while being complexly interdependent and interconnected. In the development process, which is quite out of balance, some countries have grown in national power while others are losing. These changes have brought about significant changes to the pattern of the world.

The status (or position) of a country in the international community is in essence associated with the rise and fall of its national power, and the increase and decrease of its strategic resources. This has brought us to such issues as: what is the comprehensive national power (CNP) of a country? What strategic resources make up CNP? What kinds of strategic resources are more important in the twenty-first century? What are the advantages and disadvantages of China in strategic resources vis-à-vis other great powers? Where does China stand in the world with regard to CNP? Has it gained or lost in strength over the past twenty years? How is China's CNP changing compared with the United States, Japan, India and Russia, which are closely associated with China's national interests and geopolitical strategy? How should China raise its CNP, and how should it make full use of its advantageous strategic resources while constantly improving its disadvantageous strategic resources? What are the objectives of China's grand strategies, and how can they be achieved? 


\section{Economic and social transformation in China}

\section{CNP and national strategic resources}

\section{The concept of $\mathrm{CNP}$}

CNP generally means the sum total of the power or strengths of a country's economy, military affairs, science and technology, education, resources and its influence. ${ }^{2}$ More abstractly, it refers to the combination of all the powers possessed by a country for the subsistence and development of a sovereign state, including material and ideational ethos, and international influence as well. ${ }^{3}$ Foreign scholars usually use national power in its specific sense, that is, the strategic capabilities by which a sovereign state uses its overall resources to influence others. ${ }^{4}$ It is the most important indicator in measuring the basic national conditions and resources of a country, and a comprehensive indicator for the economic, political, military and technological powers of a country. Comparing the analysis of CNP by Chinese and foreign scholars, we can draw the following conclusion: CNP has a wider coverage, emphasizing comprehensiveness and all aspects, including material strength, ideational ethos and international influence. "National Strategic Resources" stresses material strength or command power, though it does not ignore completely the importance of ideational ethos or soft power. The Klein equation, for instance, puts the ideational factor in an important place in implementing the will to pursue national strategy. In sum, both CNP and national strategic resources focus on the study of grand strategy; the two concepts have no fundamental differences and may be interchangeable.

But there is not yet a unified definition or method for calculating CNP or national power of a country. Ashley Tellis defines national power as a product of the interaction of two components, namely, the capability of a country to command its economic innovation cycle at a given time and to use such command power to form effective military capabilities and, in turn, to create a stable political environment, to intensify existing economic advantages and to provide basic conditions for maintaining its strategic advantages and seeking gains in the international system. ${ }^{5}$ In a word, CNP may be simply defined as the comprehensive capabilities of a country to pursue its strategic objectives by taking actions internationally, and the core factors of the concept are strategic resources, strategic capabilities and strategic outcomes, with strategic resources as the material base. This chapter focuses on national strategic resources with an emphasis on tangible strategic resources or hard power. We will study intangible strategic resources or soft power in another chapter.

We define national strategic resources as the real and potential key resources available for realizing the strategic outcomes of a country. They reflect a country's abilities in utilizing all kinds of resources worldwide and also reflect the country's CNP. Kenneth Waltz defines powers as the distribution of all kinds of capabilities. In fact, CNP is the distribution of the strategic resources of a country, to mobilize and utilize strategic resources to achieve the strategic objectives of a country. Generally speaking, CNP refers to the sum total of the 
strategic resources of a country while the strategic resources of country refer to certain kinds of strategic resources.

\section{National strategic resources}

Michael Porter lists five major resources, namely, physical resources, human resources, infrastructure resources, knowledge resources and capital resources. ${ }^{6}$ Accordingly, we divide national strategic resources into eight categories, with twenty-three indictors. These indicators constitute CNP.

\section{1) Economic resources}

We measure economic resources by gross national product (GNP) or gross domestic product (GDP). GNP, as usually used to measure the economic scale, is the value of final goods and services produced by domestically owned factors of production within a given period of time. It includes taxes excluded in total output value minus any subsidies, and major income of non-residents (employment compensation and asset income). GNP also includes GDP and nonresidents' major incomes. Usually, there are two ways of measuring GDP. One is calculated by the official or nominal exchange rate. This method often underestimates the economic power of developing countries, but overestimates the economic power of developed countries. The other method is calculated by the purchasing power parity (PPP). Sometimes, the US dollar converted using PPP is called the international dollar. The international comparison project (ICP) of the World Bank and the IMF takes 1993 as the base and calculates the GNP of 118 countries and uses PPP to estimate per capita GNP and per capita GDP in terms of the international dollar.

\section{2) Human capital resources}

Human capital, especially the opportunities and capabilities of acquiring education, is regarded as the determining factor in the process of economic growth. Generally, human capital is expressed in the number of years of education received by the population. The more the number of years of education received, the more skillful the workers and the higher the labor productivity. The rich human resources of developing countries make it easier for them to absorb and use new technologies imported and disseminated from the developed countries. ${ }^{7}$ The total human capital of a country is expressed in two categories of indicators: one is the number of people and the number of working-aged people, such as people aged 15-64; the other is human capital, which is expressed in the average number of years of education received by people over the age of $15 .{ }^{8}$ These two categories of indicators constitute the total human capital of a country, which is defined as the number of working-aged people multiplied by the average number of years of education received, or defined as the multiplication of labor forces and the average number of years of education received by the population. Labor 
forces refer to people who are economically active as defined by the International Labor Organization. This includes people who provide labor service to producers and services at a given stage. They include both people with jobs and people without. The estimated figure for females does not have international comparability, because in many developing countries most of the female laborers help with farm work or engage in labor without pay in family businesses. In general, labor forces include soldiers, unemployed people and people who are searching for jobs for the fist time, but do not include family workers or other service workers without pay and people working in non-regular working units.

\section{3) Natural resources}

Usually, natural resources refer to the abundance, quality, accessibility and costs of major natural resources. Natural resources are the necessary conditions for economic development, but they are limited, possibly becoming constraints on the upper limit of economic growth. Meanwhile, natural resources are regressive, having marginal gains with relatively high ecological costs and external costs to their excavation and utilization. Different resources play quite different roles during different stages of development, but generally assume a downward trend, whereas the roles of knowledge resources assume an upward trend. There are four major indicators for natural resources: (1) arable land, referring to temporary and permanent arable land and permanent farm and pasture defined by the FAO of the UN; (2) fresh water resources, including domestic river water at current volume, underground water accumulated from precipitation and river current volume from river flows in from other countries; (3) commercial energy usage, referring to energy consumption which is equal to domestic production plus imports and inventory changes, minus exports and fuel supplied to ships and aircraft engaged in international transport; and (4) electricity production, measured at the terminals of all alternator sets in a power station. In addition to hydropower, coal, oil, gas, and nuclear power generation, this also includes geothermal, solar, wind, and tide and wave energy, as well as that from combustible renewable material and waste.

\section{4) Capital resources}

According to the definition given by Michael Porter, capital resources include three major indicators: (1) gross domestic investment, that is, the net changes to spending on fixed assets plus the inventory level in the economy of a country; (2) foreign direct investment (FDI), that is, the net inflows of investment to acquire a lasting management interest in an enterprise operating in an economy other than that of the investor; this is the sum of equity capital, reinvestment of earnings, other long-term capital, and short-term capital, as shown in the balance of payments; and (3) market capitalization (also known as market value), that is, the share price times the number of shares outstanding, which reflects the size of the financial market. ${ }^{9}$ In this chapter, we have converted domestic 
investment into international dollars, but the other two indicators are calculated in US dollars.

\section{5) Knowledge and technology resources}

We deem knowledge and technology resources the most important strategic resources. In the twenty-first century, the world entered into a knowledge and information era. Knowledge and technology resources are becoming more and more important. Knowledge and technology resources include five major indicators: (1) number of scientific thesis, including number of thesis published in about 4,800 international academic publications, which reflect the knowledge innovation capability of a country; (2) patent applications by domestic residents, which reflect the technology innovation capability of the country; (3) number of personal computers (PCs), which shows the country's capabilities of applying new technologies; (4) Internet hosts, i.e., computers with active Internet protocol (IP) addresses connected to the Internet, which reflect the capabilities of a country in information dissemination; and (5) government spending on R\&D, that is, the potential knowledge and technology innovation capabilities of a country in the long run. These five indicators present a full picture of a country in promoting knowledge innovation and dissemination, technology innovation and proliferation in the information era.

\section{6) Government resources}

Due to limitations by quantitative indicators, we use only one indicator here, that is, the fiscal spending of the central government, which includes both current and capital spending, both commercial and service spending and spending on both non-financial public undertakings and public organizations. This reflects the ability of a national government to mobilize and utilize resources.

\section{7) Military power}

Military power is an important component of CNP. It reflects the abilities of a country to maintain social stability and prevent separatism. It also reflects the external power of a nation in seeking the maximization of interests abroad. Military power is also a kind of "output" of national power. ${ }^{10}$ It is an extremely important strategic asset, because military power is not only an explicit function of CNP, but also an expressive function of the will of a state. Military resources have two categories of indicators: (1) military expenditures which cover military-related expenditures of the Ministry of Defense and other ministries (including recruiting, training, construction, and the purchase of military supplies and equipment), excluding civil expenditures of the Ministry of Defense; and (2) armed forces personnel which refers to military personnel on duty and quasi military personnel. However, the two indicators cannot reflect the quality of military resources of a country. 


\section{8) International resources}

International resources include four categories of indicators: (1) volume of exports and services; (2) volume of imports and services; (3) royalty and license fees receipts; and (4) royalty and license fees payments. The first two indicators reflect the ability of a country to utilize and open up international markets; the last two reflect the ability of a country to create and utilize international technologies.

\section{Methods of measuring CNP}

To measure and evaluate CNP, it is necessary to develop a new method that can be widely applied and has strong measurability and comparability. Here we will introduce the traditional methodologies and equations and then introduce a multiple-indicator dynamic equation and computation method developed by the authors.

\section{Traditional measurement}

Klause Knorr defined national power as power that includes economic capabilities, administrative competitiveness and the ability of war mobilization. ${ }^{11}$ This is the earliest equation for calculating national power, which shows that people already knew that national power does not mean only economic strength, although the latter provides the foundation for national power.

A complex nonlinear multivariable index that attempts to both identify discrete variables and specify their interrelationships came in 1960 with the work of Clifford German, who produced a world power index in the following form:

$$
\mathrm{G}=\text { National Power }=\mathrm{N}(\mathrm{L}+\mathrm{P}+\mathrm{I}+\mathrm{M}),
$$

where $\mathrm{N}$ stands for nuclear capability, L stands for territory, P stands for population, I stands for the industrial base, and $\mathrm{M}$ stands for military size. This is a national power equation centering upon nuclear capabilities. The national power is positively correlated to nuclear capability. It reflects the special importance of having nuclear weapons during the Cold War and the nuclear era. In fact, all major countries have made all necessary efforts to develope nuclear weapons after World War II to accumulate the most important strategic resources and tactical means.

A semi-nonlinear multivariable index was subsequently proposed by Wilhelm Fucks in 1965, who sought to derive national power from three variables population size (P), energy production (Z), and steel production (Z1) - arranged in one of nine formulas for measuring the national power $(\mathrm{M})$, all of which were variants of one another and took the following form:

$$
\begin{aligned}
& M=\left(P^{\wedge} 2\right) \times Z \\
& M=\left(P^{\wedge}(3 / 2)\right) \times Z 1
\end{aligned}
$$


The equation is based on the traditional resources in the era of industrialization. The strategic objectives are to obtain more energy in the world and to raise industrial productivity.

In 1975, Ray Cline defined a national power equation as the following:

$$
\mathrm{P}_{\mathrm{p}}=(\mathrm{C}+\mathrm{E}+\mathrm{M}) \times(\mathrm{S}+\mathrm{W})
$$

where $\mathrm{C}$ stands for population and territory, E stands for economic capacity, $\mathrm{M}$ stands for military capacity (including the strategic balance plus combat capabilities and a bonus for effort), S stands for the national strategy coefficient, and $\mathrm{W}$ stands for national will (including the level of national integration, the strength of leadership, and the relevance of strategy to the national interest). This is a CNP formula. The first part of the equation reflects the objective strength or hard factors and the second part reflects the subjective strength or soft factors. CNP is the multiplication of the two, reflecting the importance attached by researchers to soft factors. However, soft factors are difficult to calculate. This method was once used by the US military to estimate the longterm trends of the international system.

Ashley Tellis and other scholars of RAND are the first to propose a method to evaluate the national power of a country in the post-industrialization era. They hold that traditional indicators and methods are unable to reflect national power in the information age. They have introduced many new concepts and ideas in their research, but neither equations for calculation nor result of the calculation.

Traditional approaches just give simple rank-ordering of capabilities, but do not identify the real gaps and relative changes of the indicators. It is, in fact, only a semi-quantitative method. We hope to develop a comprehensive quantitative method that tracks the relative dynamic changes in CNP of great powers.

\section{The CNP calculation methods proposed by Chinese scholars}

The Chinese Academy of Social Sciences has developed an indicator system and weighted average scheme that covers eight aspects and sixty-four indicators. ${ }^{12}$ The basic method is to process the hard indicators in a standard way and use Cline's integrated scoring method to make indicators of different measures to transit to standard collectable data. Then, we can obtain the basic data sheet after simple addition and collection level by level. On this basis, various countries can be ranked according to their national capacity. Qualitative and quantitative analysis will allocate a certain weighted average according to different levels to make corrections and adjustments of the basic data to obtain the weighted average data sheet, with which to make comparisons.

The method proposed by the Chinese Military Academy holds that CNP should be the organic integration of capacities for subsistence, development and coordination. ${ }^{13}$ Thus, a "CNP dynamic equation" was designed, which takes the following form:

$$
\mathrm{P}=\mathrm{K} \times \mathrm{H} \times \mathrm{S}
$$


where $\mathrm{P}$ is $\mathrm{CNP}$ of a given year; $\mathrm{K}$ is the coordination system, including factors such as the capacities of national leaders to coordinate and unify; $\mathrm{H}$ is hardware, including all physical factors; and $\mathrm{S}$ is software, including ideational ethos, intelligence and other factors.

An analytic hierarchical process was developed by the China Institute of Contemporary International Relations. This, plus expert surveys, regression analysis, nerves network and cluster analysis, led to the initial creation of a CNP indicator system. Data were then collected according to the indicators and processed in a standard and dimensionless manner, establishing the weighted average for each indicator and, on this basis, computing the value of CNP.

According to the study of Chinese scholars, the ranking in CNP of five major powers in 1998 was the United States, Japan, Russia, China and India. ${ }^{14}$ From this, we may conclude that the Chinese scholars stress the integration of qualitative and quantitative analysis, with an emphasis on quantitative analysis. But these models of analysis are mainly confined to traditional approaches.

\section{A new method and its characteristics}

This chapter introduces the following formula of CNP:

$$
\mathrm{NP}=\Sigma(\text { ai } \times \mathrm{Ri})
$$

where NP is CNP, $\mathrm{Ri}$ is the percentage of a certain resource in the world total, and ai is the weighted average of a certain resource. When the time variable is considered, the formula takes the following form:

$$
N P(t)=\Sigma(a i \times \operatorname{Ri}(t))
$$

The characteristics of the method are explained as follows:

First, we adopt the dimensionless specific gravity method to compute the percentage of major strategic resources of countries in the world total. CNP refers to relative national power. What we are more concerned about is whether or not CNP or strategic resources of a country rise or fall relative to another country. Since the units of the more than twenty indicators are different and cannot be added up, we use the gravity method (to convert different units into a unified unit - percentage) to add them up to constitute CNP. On this basis, we make international and historical comparisons.

Secondly, we define eight kinds of strategic resources and twenty-three major indicators to constitute a computable CNP equation, which reflects, in a comprehensive manner, the strategic resources and CNP of different countries.

Thirdly, we adopt different weighted averages for different indicators to represent their respective importance. For instance, the weighted average of the strategic assets in the knowledge or information age is different from that in the industrial age. The former includes mainly knowledge, technology, information and other new strategic resources, whose roles are swiftly on the rise. The latter includes territory, food, grain, energy, iron and steel and other traditional 
Table 2.1 Strategic resources and major indicators

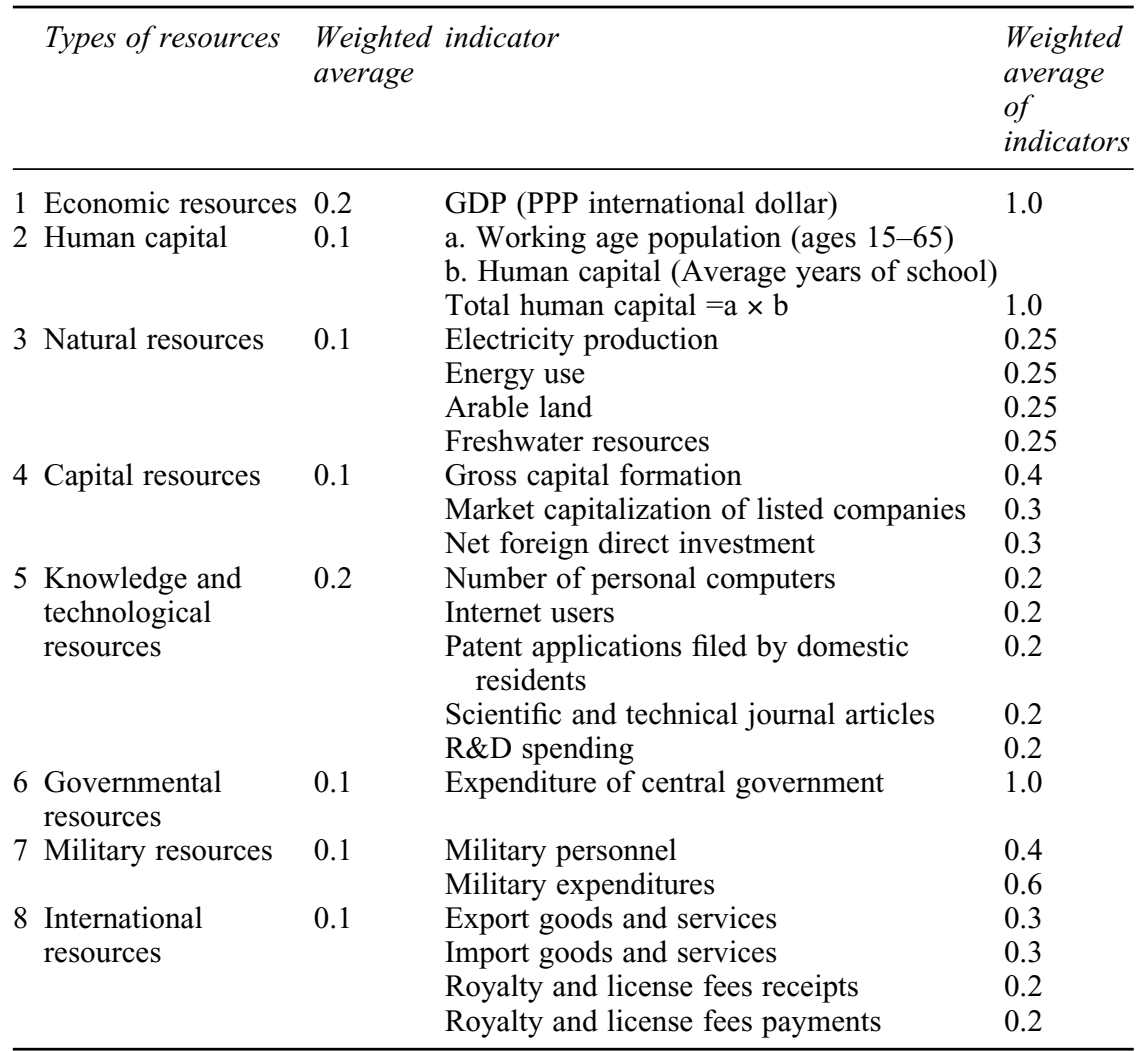

Source: World Bank, World Development Indicator 2002 CD-ROM.

Notes: The chapter uses the World Development Indicator Database 2004, which contains more than 500 economic and social indicators of 206 countries and regions in 1960-2000. In calculating human capital (average number of years of education received by people above the age of 15 years), the paper uses Barro and Lee's International Measures of Schooling Years and Schooling Quality data set. Available online at http://www.worldbank.org/research/growth/aer96bl.htm> (accessed August 8, 2003).

resources, whose roles are declining. In view of this, the chapter gives a considerably high weighted average to knowledge and technology (see Table 2.1).

Fourthly, the equation is dynamic, changing with the times. It not only reflects $\mathrm{CNP}$ or the strategic resources of a country relative to another country, but also the dynamic changes among them.

\section{Dynamic changes of the CNP of five great powers (1980-2000)}

The economic, political and security patterns of the modern world have been influenced by the rivalry of a few major powers. The world has not been in balance or in peace. Over the past two decades, the relative CNP of the five major powers has changed, reflecting the imbalanced development among the super or big powers. Some are rising, some are falling and some are not changing much. 
42 Economic and social transformation in China

Table 2.2 Strategic resources and CNP of five countries (1980-2000) (\% in world total)

\begin{tabular}{|c|c|c|c|c|c|c|}
\hline Country & 1980 & 1985 & 1990 & 1995 & 2000 & $\begin{array}{l}\text { Change from } \\
1980-2000\end{array}$ \\
\hline \multicolumn{7}{|c|}{ Economic resources } \\
\hline China & 3.16 & 4.57 & 5.63 & 8.87 & 11.16 & 8.00 \\
\hline India & 3.36 & 3.80 & 4.35 & 5.02 & 5.46 & 2.10 \\
\hline Japan & 8.04 & 8.27 & 8.73 & 8.38 & 7.54 & -0.50 \\
\hline Russia & - & - & 5.43 & 3.02 & 2.62 & - \\
\hline US & 21.96 & 21.60 & 20.85 & 20.73 & 21.64 & -0.32 \\
\hline Five in total & - & - & 44.99 & 46.02 & 48.42 & - \\
\hline \multicolumn{7}{|c|}{ Human capital } \\
\hline China & 17.6 & 18.7 & 20.2 & 21.9 & 24.0 & 6.40 \\
\hline India & 8.40 & 9.06 & 9.98 & 11.1 & 12.3 & 3.90 \\
\hline Japan & 4.36 & 4.01 & 3.73 & 3.55 & 3.27 & -1.09 \\
\hline Russia & 5.69 & 5.30 & 5.05 & 4.26 & 4.06 & -1.63 \\
\hline US & 1.16 & 1.02 & 9.30 & 9.01 & 8.60 & 7.44 \\
\hline Five in total & 47.7 & 47.2 & 48.2 & 49.8 & 52.2 & 4.50 \\
\hline \multicolumn{7}{|c|}{ Natural resources } \\
\hline China & 8.65 & 8.57 & 9.30 & 9.62 & 9.74 & 1.09 \\
\hline India & 6.68 & 6.75 & 6.97 & 6.59 & 6.88 & 0.20 \\
\hline Japan & 3.34 & 3.23 & 3.41 & 3.54 & 3.39 & 0.05 \\
\hline Russia & & & & 7.57 & 6.97 & - \\
\hline & 18.29 & 16.81 & 16.42 & 15.95 & 15.82 & -2.47 \\
\hline Five in total & & & & 43.26 & 42.79 & - \\
\hline \multicolumn{7}{|c|}{ Capital resources } \\
\hline China & 2.21 & 3.81 & 3.87 & 10 & 10.14 & 7.93 \\
\hline India & 1.5 & 2.16 & 2.0 & 2.7 & 2.22 & 0.72 \\
\hline Japan & 5.25 & 5.52 & 14.4 & 10.5 & 7.12 & 1.87 \\
\hline Russia & & & & 1.5 & 2.27 & - \\
\hline US & 23.02 & 20.33 & 23.4 & 23.8 & 25.54 & 2.52 \\
\hline Five in total & & & 43.67 & 48.5 & 47.29 & - \\
\hline \multicolumn{7}{|c|}{ Knowledge and technological resources } \\
\hline China & 0.79 & 0.94 & 1.01 & 1.34 & 2.82 & 2.03 \\
\hline India & 2.23 & 2.01 & 1.23 & 0.85 & 1.14 & -1.09 \\
\hline Japan & 8.23 & 9.17 & 8.56 & 15.32 & 14.70 & 6.47 \\
\hline Russia & & & 0.08 & 1.76 & 1.64 & - \\
\hline US & 32.69 & 32.8 & 34.26 & 34.59 & 35.19 & 2.50 \\
\hline Five in total & & & 45.14 & 53.86 & 55.49 & - \\
\hline \multicolumn{7}{|c|}{ Governmental resources } \\
\hline China & 1.84 & 1.48 & 1.16 & 1.03 & 2.60 & 0.76 \\
\hline India & 1.63 & 2.10 & 2.66 & 2.46 & 3.54 & 1.91 \\
\hline Japan & 5.83 & 5.18 & 5.24 & 7.60 & $7.06^{*}$ & 1.23 \\
\hline Russia & & & & 2.60 & 2.33 & - \\
\hline US & 19.1 & 19.0 & 18.7 & 15.9 & 16.13 & -2.97 \\
\hline Five in total & & & & 29.05 & 31.66 & - \\
\hline \multicolumn{7}{|c|}{ Military resources } \\
\hline China & & 8.57 & 7.91 & 7.31 & 9.04 & 0.47 \\
\hline India & & 3.97 & 4.14 & 5.01 & 6.69 & 2.72 \\
\hline Japan & & 1.50 & 1.84 & 2.38 & 2.19 & 0.69 \\
\hline Russia & & & & 6.40 & 4.39 & - \\
\hline US & 21.07 & 21.24 & 21.55 & 19.83 & 20.99 & -0.25 \\
\hline Five in total & & & & 42.65 & 43.30 & - \\
\hline
\end{tabular}


Table 2.2 continued

\begin{tabular}{lcccccl}
\hline Country & 1980 & 1985 & 1990 & 1995 & 2000 & $\begin{array}{l}\text { Change from } \\
1980-2000\end{array}$ \\
\hline International & resources & & & & & \\
China & 0.59 & 0.91 & 0.74 & 1.35 & 2.43 & 1.84 \\
India & 0.40 & 0.49 & 0.44 & 0.48 & 0.60 & 0.20 \\
Japan & 7.55 & 9.05 & 9.97 & 10.38 & 9.78 & 2.23 \\
Russia & - & - & - & 0.82 & 0.71 & - \\
US & 22.47 & 24.01 & 22.10 & 22.18 & 24.44 & 1.97 \\
Five in total & - & - & - & 35.21 & 37.96 & - \\
CNP & & & & & & \\
China & 4.736 & 5.306 & 5.646 & 7.163 & 8.770 & 4.034 \\
India & 3.376 & 3.615 & 3.735 & 4.008 & 4.543 & 1.167 \\
Japan & 6.037 & 6.337 & 7.317 & 8.535 & 7.729 & 1.692 \\
Russia & - & - & 3.271 & 2.808 & 2.925 & - \\
US & 22.485 & 22.022 & 22.138 & 21.903 & 22.518 & 0.033 \\
Five in total & - & - & 42.107 & 41.613 & 46.481 & - \\
\hline
\end{tabular}

Source: World Bank, World Development Indicators 2004 CD-ROM.

Notes:

1. The weighted average of economic and technology resources are both 0.2 and that of other resources is 0.1 .

2. The lack of some data does not affect the accuracy in the judgment of the general trend.

The United States remains the world's superpower. The CNP of the United States in 1980 accounted for 22.485 percent of the world total and 22.518 percent in 2000. The US still ranks first in the world.

China has risen to become the second world power. In 1980, the CNP of China accounted for 4.763 percent of the world total, lower than that of the former Soviet Union and Japan, ranking fourth in the world. But by 2000, China's CNP as a share of the world total rose to 8.770 percent, rising by 4.034 percentage points. The relative gap between China and the United States has also narrowed. The CNP of China was only one-fifth (21 percent) of the United States in 1980, and one-quarter (25.5 percent) in 1990, but rose to more than one-third (39 percent) by 2000 . In other words, the gap between the United States and China in terms of CNP has been narrowed from five times to three times over the past two decades.

Japan's CNP accounts for 4.763 percent of the world total, ranking it third in the world. It rose first in 1980-1995 and then fell comparatively after the 1990s. India ranks fourth in the world, with a CNP accounting for 4.543 percent of the world total. The relative gap between China and India expanded from 1.4 times to 1.9 times. Russia has fallen in CNP. It was 2.925 percent of the world total in 2000, the lowest of the five major powers. The gap between China and Russia has been grown from 2.2 times in 1995 to 3.0 times in 2000.

The relative changes in CNP of the five major countries inevitably caused major adjustments to national security and foreign policy strategies in these countries. In the eyes of the United States, the rapid rise of China's CNP will 


\section{Economic and social transformation in China}

inevitably make China its strategic rival. It is, therefore, necessary to adopt precautionary and containment strategies against China. Paul Kennedy, a Professor at Yale University, holds that China is perhaps the only country that will constitute real challenges to the dominance of the United States. ${ }^{15}$ Japan, however, has already seen China as a real strategic threat, so it has strengthened its strategic alliance with the United States against China. China has always been a major strategic threat to India, and India has long maintained its military spending at about 2.4-3.5 percent of its GDP. Russia, due to the rapid decline in its CNP, has found its gap with China enlarging. At present, Russia's strategy is favorable to China, yet its future strategy is not clear. All the above shows that over the past two decades, China's CNP has been rising rapidly, and with its strategic resources and environment improving, China is becoming more powerful in terms of CNP than its neighboring great powers (see Figure 2.1). But the latent strategic conflict between China and the United States is increasing.

\section{Dynamic evaluation of China's strategic resources}

Our initial computation results show:

First, computed by PPP, the percentage of China's economic resources in the world's aggregate has been rising swiftly, with the relative gap to the United States narrowing significantly. China has not only become the largest emerging economy and market, but also will become the world's largest economic entity.

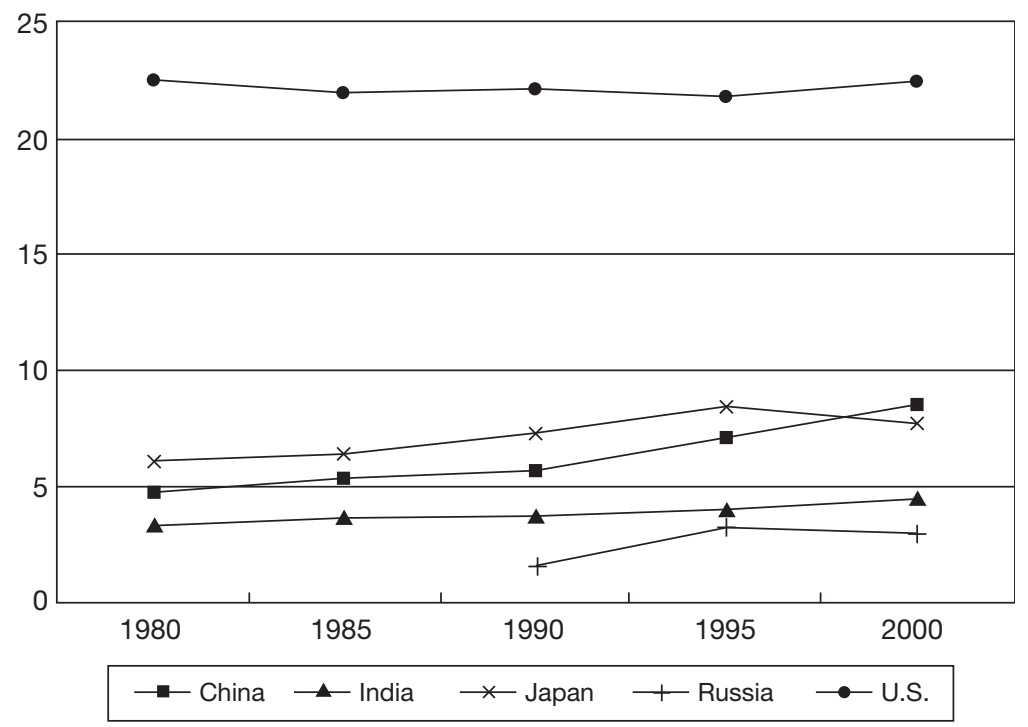

Figure 2.1 Percentage of comprehensive national power in world total (1980-2000)

Source: World Bank, World Development Indicators 2002. 
According to the statistics of Guojia tongjiju (China's State Statistical Bureau), China's GDP in 2000 was 7.3 times that of 1978, averaging an annual growth of 9.5 percent. ${ }^{16}$ China's GDP increased by nearly eight times (7.9 times) between 1978 and 2001.

Calculated by the PPP international dollar (current price), China's GDP accounted for 2.78 percent of the world total in 1975, lower than the Soviet Union (no. 2 in the world) and Japan (no. 3 in the world). By 1990, however, the percentage rose to 5.63 percent, outstripping Russia to rank after Japan. By 1995 , the figure rose to 8.87 percent, replacing Japan as second in the world, outranked only by the United States. By 2000, the figure rose to 11.16 percent (see Table 2.3), 8.38 percentage points higher than in 1975 when China's GDP was only 12.3 percent of the GDP aggregate of the United States.

According to the 2000 Global Competitiveness Report by the World Economic Forum and the International Development Institute of Harvard University, the top ten countries in terms of GDP in the world for 1999 (calculated by PPP international dollars) were U.S.A. (100), China (51.2), Japan (34.7) Germany (21.4), India (20.8), France (15.0), UK (14.5), Italy (14.4), Brazil (12.3) and Russia (11.0). ${ }^{17}$

According to a study by Angus Maddison, based on 1990's PPP international dollar, the study showed that in 1978, China's GDP accounted for 4.9 percent

Table 2.3 Economic resources of China, US, India, Japan and Russia (1975-2000)

\begin{tabular}{lcrrrrrr}
\hline Country & 1975 & 1980 & 1985 & 1990 & 1995 & 1998 & 2000 \\
\hline GNI (PPP, & S billions) & & & & & & \\
China & 212 & 414 & 821 & 1520 & 3080 & 3850 & 4966 \\
India & 266 & 441 & 683 & 1170 & 1740 & 2030 & 2432 \\
Japan & 598 & 1050 & 1490 & 2350 & 2910 & 2940 & 3354 \\
Russia & - & - & - & 1460 & 1050 & 948 & 1168 \\
US & 1730 & 2880 & 3880 & 5620 & 7200 & 8000 & 9646 \\
World total & 7623 & 13115 & 17955 & 26967 & 34730 & 37595 & 44506 \\
Percent of & GNI in world total & & & & & \\
China & 2.78 & 3.16 & 4.57 & 5.63 & 8.87 & 10.23 & 11.16 \\
India & 3.49 & 3.36 & 3.80 & 4.35 & 5.02 & 5.41 & 5.46 \\
Japan & 7.85 & 8.04 & 8.27 & 8.73 & 8.38 & 7.82 & 7.54 \\
Russia & - & - & - & 5.43 & 3.02 & 2.52 & 2.62 \\
US & 22.71 & 21.96 & 21.60 & 20.85 & 20.73 & 21.29 & 21.64 \\
Five in total & - & - & - & 44.99 & 46.02 & 47.27 & 48.42 \\
\hline
\end{tabular}

Source: World Bank, World Development Indicators 2004 CD-ROM.

Notes: Gross National Income (GNI) is the sum of value added by all resident producers plus any product taxes (less subsidies) not included in the valuation of output plus net receipts of primary income (compensation of employees and property income) from abroad. Data are in current US dollars converted using the World Bank Atlas method. PPP GNI is gross national income converted to international dollars using purchasing power parity rates. An international dollar has the same purchasing power over GNI as a US dollar has in the United States. See World Bank, World Development Indicators 2004, Washington DC: World Bank, 2004, p. 17.

Data for 2000 are those of the Gross National Income (GNI). 
of the world total, 11.5 percent higher than in $1998 .{ }^{18}$ The GDP of the United States in the world total rose from 21.6 percent to 21.9 percent; that of Japan rose from 7.6 percent to 7.7 percent; that of Russia dropped from 9.0 percent to 3.4 percent; and that of India rose from 3.3 percent to 5.0 percent. The percentage of China's GDP in the total of the United States rose from 22.7 percent to 52.5 percent. $^{19}$

The above evaluations show that, calculated by the PPP international dollar, China's current GDP is one-tenth of the world total, or one-half that of the United States. This is the basic estimation of China's economic strength (or relative economic strength).

China is the country with the greatest potential for development in the world. That is the basic reason why its CNP has been rising steadily. According to the 2000 Global Competitiveness Report, of the fifty-nine major countries surveyed from 1990 to 1999, China ranked first in per capita GDP growth, with 11.3 percent. India ranked the twelfth; U.S.A., the twenty-fourth; Japan, the forty-fourth; and Russia fifty-sixth, with -6.43 percent and per capita GDP dropping by 75.2 percent. $^{20}$

According to World Bank statistics, China has a great potential in its longterm growth. Take for instance the period from 1965to 1999 (including the ten-year great cultural revolution). Given the world economic growth as the average (1.00), China's GDP growth potential index was 2.45 , and its per capita GDP growth potential was 4.00. The indices for India were 1.40 and 1.50; those for Japan were 1.24 and 2.13; and those for the U.S.A. were 0.91 and 1.25 (see Table 2.4). Based on the aforesaid growth potential, China will become the biggest economic entity in the world by 2020 , with its GDP making up 22.2 percent of the world total, higher than that of the United States at 19.96 percent (see Table 2.5). According to estimates by Maddison, China's GDP would exceed that of the United States by 2015. China's GDP would make up 17.4 percent of the world total and that of the United States, 17.3 percent. ${ }^{21}$ The World Bank estimates show that China will outpace the United States in GDP by 2020 . All the estimates show that if China maintains relative social stability and realizes a sustainable economic growth, it is possible for China to become the largest economic power in the world in twenty years.

The steady rise in economic strategic resources is the most important basis for rising CNP. For more than twenty years, the rising percentage of China's GDP in the world total has played the biggest role in boosting the newly added CNP index, with a contribution of 46.4 percent.

Secondly, China has the richest human capital in the world, which is the strongest of all national strategic resources. According to the national population census, the percentage of the population aged 15-64 was 61.5 percent in 1982 , but rose to 70.15 percent by 2000 . The growth of the population aged 15-64 in the same period was 1.97 percent, higher than the natural growth of the population (1.23 percent). The number of years of education received by people at and above 15 years rose from 4.61 in 1982 to 7.11 in 2000, rising by 54 percent. The total human capital rose from 2.88 billion/year in 1982 to 
Table 2.4 Five countries economic growth trend

\begin{tabular}{lllll}
\hline Country & $\begin{array}{l}\text { GDP growth } \\
(1965-1999)\end{array}$ & $\begin{array}{l}\text { Per capita } \\
\text { GDP growth }\end{array}$ & & Growth potential index \\
\cline { 5 - 5 } & & $(1965-1999)$ & GDP & Per capita GDP \\
\hline China & 8.1 & 6.4 & 2.45 & 4.00 \\
India & 4.6 & 2.4 & 1.40 & 1.50 \\
Japan & 4.1 & 3.4 & 1.24 & 2.13 \\
Russia & - & - & - & - \\
US & 3.0 & 2.0 & 0.91 & 1.25 \\
World total & 3.3 & 1.6 & 1.00 & 1.00 \\
\hline
\end{tabular}

Source: World Bank, World Development Indicators 2001, New York: Oxford University Press, 2001, Table 1.4.

Notes: Growth potential index refers to the ratio of growth of all countries to the average growth in the world.

Table 2.5 Predicted long-term economic growth trend of the five countries (1998-2020)

\begin{tabular}{lrrrrrrr}
\hline Country & \multicolumn{3}{c}{ GDP (billion US dollars, 1998) } & & \multicolumn{3}{c}{ Percent in world total } \\
\cline { 2 - 3 } \cline { 7 - 8 } & 1998 & 2010 & 2020 & & 1998 & 2010 & 2020 \\
\hline China & 3850 & 9803 & 17057 & & 10.23 & 17.66 & 22.20 \\
India & 2030 & 3482 & 5460 & & 5.41 & 6.27 & 7.11 \\
Japan & 2940 & 4762 & 7116 & & 7.82 & 8.58 & 9.27 \\
Russia & 948 & 1202 & 1466 & & 2.52 & 2.17 & 1.90 \\
US & 8000 & 11406 & 15329 & & 21.29 & 20.55 & 19.96 \\
World total & 37595 & 55505 & 76796 & & 100.0 & 100.0 & 100.0 \\
\hline
\end{tabular}

Notes: Author's estimation based on World Bank, World Development Indicators 2001 CD-ROM, 1965-1999 data.

6.314 billion/year by 2000 , more than doubling. Of this, the contribution by population change factor (growth of population aged 15-64) was 45.2 percent. The contribution by the rise in educational level (growth in the number of years of education received by the population) was 54.8 percent. China's percentage of total human capital in the world total rose from 17.6 percent in 1980 to 24.0 percent in 2000 (see Table 2.6), doubling that of India and 2.8 times that of the United States. This shows that China has become a No. 1 big power in terms of population and total human capital. This is the biggest advantage in its national strategic resources. The contribution by human capital to rising CNP over the past twenty years ranked third or about one-fifth (21.0 percent). The full utilization of human capital will be an extremely important development strategy in the future.

Thirdly, China is a big power in terms of natural resources, ranking second in the world in the actual utilization of major natural resources. China's power consumption in the world total has risen significantly, rising from 3.15 percent in 1980 to 8.83 percent in 2000, ranking it second in the world. The percentage 
Table 2.6 Human capital of five countries (1975-2000) (\% in world total)

\begin{tabular}{|c|c|c|c|c|c|c|}
\hline Country & 1975 & 1980 & 1985 & 1990 & 1995 & 2000 \\
\hline \multicolumn{7}{|c|}{ Working age population (\% of total) (a) } \\
\hline China & 22.2 & 22.6 & 23.3 & 23.6 & 23.2 & 22.4 \\
\hline India & 14.9 & 15.2 & 15.4 & 15.7 & 15.9 & 16.2 \\
\hline Japan & 3.27 & 3.03 & 2.83 & 2.67 & 2.48 & 2.30 \\
\hline Russia & 3.93 & 3.65 & 3.35 & 3.09 & 2.81 & 2.69 \\
\hline US & 5.99 & 5.80 & 5.44 & 5.10 & 4.88 & 4.76 \\
\hline Five-country total & 50.3 & 50.3 & 50.3 & 50.1 & 49.2 & 48.4 \\
\hline \multicolumn{7}{|c|}{ Average years of school (b) } \\
\hline China (c) & 4.38 & 4.61 & 4.94 & 5.51 & 6.08 & 7.11 \\
\hline India & 2.70 & 3.27 & 3.64 & 4.10 & 4.52 & 5.06 \\
\hline Japan & 7.78 & 8.51 & 8.74 & 8.96 & 9.23 & 9.47 \\
\hline Russia & 9.27 & 9.23 & 9.77 & 10.5 & 9.77 & 10.0 \\
\hline US & 9.69 & 11.9 & 11.6 & 11.7 & 11.9 & 12.11 \\
\hline World average & 5.54 & 5.92 & 6.17 & 6.43 & 6.44 & 6.66 \\
\hline \multicolumn{7}{|c|}{ Total human capital (billion/person/year) } \\
\hline China & 2.25 & 2.70 & 3.35 & 4.17 & 4.95 & 6.00 \\
\hline India & 0.934 & 1.29 & 1.62 & 2.06 & 2.52 & 3.08 \\
\hline Japan & 0.59 & 0.67 & 0.72 & 0.77 & 0.804 & \\
\hline 0.819 & & & & & & \\
\hline Russia & 0.844 & 0.874 & 0.951 & 1.04 & 0.964 & 1.02 \\
\hline US & 1.35 & 1.79 & 1.83 & 1.92 & 2.04 & 2.16 \\
\hline World total & 12.8 & 15.4 & 17.9 & 20.7 & 22.6 & 25.0 \\
\hline \multicolumn{7}{|c|}{ Share of total human capital in worlds total } \\
\hline China & 17.5 & 17.6 & 18.7 & 20.2 & 21.9 & 24.0 \\
\hline India & 7.27 & 8.40 & 9.06 & 9.98 & 11.1 & 12.3 \\
\hline Japan & 4.60 & 4.36 & 4.01 & 3.73 & 3.55 & 3.27 \\
\hline Russia & 6.57 & 5.69 & 5.30 & 5.05 & 4.26 & 4.06 \\
\hline US & 10.5 & 11.6 & 10.2 & 9.30 & 9.01 & 8.60 \\
\hline Five-country total & 46.5 & 47.7 & 47.2 & 48.2 & 49.8 & 52.2 \\
\hline
\end{tabular}

Source: (a) World Bank, World Development Indicators 2004 CD-ROM; (b) R. Barro and J. Lee, "International Data on Educational Attainment Updates and Implication," NBER Working Paper, 2000; (c) data for China from Guojia tongjiju (National Bureau of Statistics of China), Zhongguo tongji zhaiyao 2001 (China Statistical Abstract 2001), Beijing: Zhongguo tongji chubanshe (China Statistics Press), 2001, p. 36.

Notes: Working age populations refer to the population ages 15-64. Average years of school refer to the average years of education for those over 15 . Total human capital refers to the working age population times the average years of school.

of commercial energy in the world total also rose, from 8.18 percent in 1980 to 11.56 percent in 2000, ranking it second in the world. But the percentage of sowing area of crops has been falling steadily, dropping from 17.01 percent in 1980 to 12.76 percent in 2000, also ranking it second in the world, lower than India. But its percentage of water sources remains unchanged. China's natural resources in the world rose from 8.54 percent in 1975 to 9.74 percent in 2000, ranking it second in the world in terms of available natural resources, only after the United States (see Table 2.7). China's percentage of natural 
Table 2.7 Natural resources of five countries (1975-2000) (\% in world total)

\begin{tabular}{|c|c|c|c|c|c|c|}
\hline Country & 1975 & 1980 & 1985 & 1990 & 1995 & 2000 \\
\hline \multicolumn{7}{|c|}{ Electricity production ( $k w h)$} \\
\hline China & 3.15 & 3.82 & 4.43 & 5.54 & 7.86 & 8.83 \\
\hline India & 1.33 & 1.46 & 1.89 & 2.47 & 3.17 & 3.53 \\
\hline Japan & 7.35 & 6.99 & 6.87 & 7.25 & 7.45 & 7.05 \\
\hline Russia & - & 9.82 & 9.91 & 9.23 & 6.52 & 5.71 \\
\hline US & 31.23 & 29.63 & 27.02 & 27.12 & 27.02 & 26.09 \\
\hline Five in total & - & 51.72 & 50.12 & 51.61 & 52.02 & 51.22 \\
\hline \multicolumn{7}{|c|}{ Commercial energy use } \\
\hline China & 8.18 & 8.68 & 9.18 & 10.07 & 11.84 & 11.56 \\
\hline India & 3.51 & 3.5 & 3.76 & 4.18 & 4.82 & 5.08 \\
\hline Japan & 5.19 & 5.01 & 4.73 & 5.1 & 5.49 & 5.31 \\
\hline Russia & 10.24 & 11.03 & 11.7 & 10.5 & 6.9 & 6.21 \\
\hline US & 27.98 & 26.17 & 22.94 & 22.37 & 23.06 & 23.26 \\
\hline Five in total & 55.1 & 54.39 & 52.31 & 52.22 & 52.11 & 51.41 \\
\hline \multicolumn{7}{|l|}{ Arable land } \\
\hline China & 17.01 & 16.3 & 14.87 & 15.79 & 12.96 & 12.76 \\
\hline India & 17.58 & 17.85 & 17.44 & 17.31 & 14.45 & 14.98 \\
\hline Japan & 0.52 & 0.47 & 0.45 & 0.42 & 0.34 & 0.31 \\
\hline Russia & - & - & - & - & 7.65 & 6.75 \\
\hline US & 12.51 & 12.28 & 12.2 & 11.08 & 8.62 & 8.84 \\
\hline Five in total & - & - & - & - & 44.02 & 43.64 \\
\hline \multicolumn{7}{|c|}{ Freshwater resources } \\
\hline China & 5.8 & 5.8 & 5.8 & 5.8 & 5.8 & 5.8 \\
\hline India & 3.91 & 3.91 & 3.91 & 3.91 & 3.91 & 3.91 \\
\hline Japan & 0.88 & 0.88 & 0.88 & 0.88 & 0.88 & 0.88 \\
\hline Russia & 9.22 & 9.22 & 9.22 & 9.22 & 9.22 & 9.22 \\
\hline US & 5.09 & 5.09 & 5.09 & 5.09 & 5.09 & 5.09 \\
\hline Five in total & 24.9 & 24.9 & 24.9 & 24.9 & 24.9 & 24.9 \\
\hline \multicolumn{7}{|c|}{ Total natural resources } \\
\hline China & 8.54 & 8.65 & 8.57 & 9.30 & 9.62 & 9.74 \\
\hline India & 6.58 & 6.68 & 6.75 & 6.97 & 6.59 & 6.88 \\
\hline Japan & 3.49 & 3.34 & 3.23 & 3.41 & 3.54 & 3.39 \\
\hline Russia & - & - & - & - & 7.57 & 6.97 \\
\hline US & 19.20 & 18.29 & 16.81 & 16.42 & 15.95 & 15.82 \\
\hline Five in total & - & - & - & - & 43.26 & 42.79 \\
\hline
\end{tabular}

Source: World Bank, World Development Indicators 2004 CD-ROM.

Notes: Electricity production is measured at the terminals of all alternator sets in a station.

Freshwater resources refer to total renewable resources, broken down between internal flows of rivers and groundwater from rainfall in the country, and river flows from other countries. Freshwater resources per capita are calculated using the World Bank's population estimates.

Commercial energy use refers to apparent consumption, which is equal to indigenous production plus imports and stock changes, minus exports and fuel supplied to ships and aircraft engaged in international transport.

Arable land includes land defined by the Food and Agriculture Organization of the United Nations (UNFAO) as land under temporary crops (double-cropped areas are counted once), temporary meadows for mowing or for pasture, land under market or kitchen gardens, and temporarily fallow land. Land abandoned as a result of shifting cultivation is excluded.

Total natural resources equal all natural resources plus weight average (in all the cases, weight average is $25 \%$ ). 
resources in the world total rose by only 1.09 percentage points, with their contribution to the newly added CNP being only 2.9 percent. This also reflects the fact that the percentage of China's population is higher than the percentage of natural resources in the world total, but the per capita natural resources and utilization are lower than the world's average, without any comparative advantages.

Fourth, the percentage of China's capital resources in the world total has risen rapidly, with greater potential to tap. At the beginning of reform, China was relatively short of capital resources. In 1980, the total domestic investment made up only 4.4 percent of the world total. There was no foreign direct investment and there was no capital market. Its capital resources accounted for only 2.21 percent of the world total. With opening up to the outside world and the development of the financial market, this percentage rose to 3.87 percent in 1990 and up to 10.14 percent by 2000 (see Table 2.8). Compared with the United States, the amount of domestic investment in the world total was slightly higher than the United States. China's foreign exchange reserves were more than the United States. But the capital market (market value of the stock market) was far lower than the United States. In 2000, the market value of the U.S. stock market was twenty-six times that of China's. Conversely, China has great potential in the development of its capital market, depending on how to open up, develop and standardize the capital market.

Fifth, China is poor in knowledge and technological resources, the weakest of all its national strategic resources. In 1980, China's knowledge and technological resources accounted for only 0.79 percent of the world total. In the 1990s, China's knowledge and technological resources in the world total rose to 2.82 percent due to the rapid increase in mobile phones. But in the same period, the percentage of the United States was 35.19 percent and that of Japan, 14.7 percent. China's knowledge innovation capabilities (number of scientific papers) were very low, accounting for only 2.21 percent of the world total. Technical innovation capabilities (number of patent applications filed by residents) accounted for only 2.82 percent of the world total (see Table 2.9). In reality, only 0.2 percent and 0.1 percent of the patents filed by Chinese residents were approved by the United States and Europe, respectively. Over the past dozen years, about 75 percent of the Nobel prize winners in the natural sciences, economics and sciences of medicine did research or lived in the United States. Most of the information on the Internet came from the United States. ${ }^{22}$ In 1999, the number of scientists and technical personnel in China reached 2.91 million, including 1.59 million scientists and engineers. ${ }^{23}$ According to the World Bank statistics, there were 1.02 million scientists and engineers engaged in R\&D in the United States. The number in Japan was 620,000. China ranked third, with 570,000; Russia, 520,000; and India, $150,000 .{ }^{24}$ No matter how it was counted, China was lower than the other four major powers in terms of the number of papers and patents. This shows that although China has relatively abundant numbers of scientific and technical personnel (ranking third in the world), the current scientific and technical system has not shaken off the shadows 
Table 2.8 Capital resources of five countries (1975-2000) (\% in world total)

\begin{tabular}{|c|c|c|c|c|c|c|}
\hline & 1975 & 1980 & 1985 & 1990 & 1995 & 2000 \\
\hline \multicolumn{7}{|c|}{ Gross capital formation } \\
\hline China & 3.45 & 4.41 & 7.61 & 8.32 & 16.26 & 18.23 \\
\hline India & 2.92 & 2.73 & 3.96 & 4.56 & 5.77 & 4.66 \\
\hline Japan & 10.56 & 10.29 & 10.26 & 11.99 & 10.76 & 10.20 \\
\hline Russia & - & - & - & 6.96 & 3.15 & 5.02 \\
\hline US & 16.19 & 17.43 & 19.16 & 14.99 & 16.07 & 16.22 \\
\hline Five in total & - & - & - & 46.82 & 52.01 & 54.33 \\
\hline \multicolumn{7}{|c|}{ Market capitalization of listed companies } \\
\hline China & 0 & 0 & 0 & 0 & 0.24 & 1.80 \\
\hline India & - & - & - & 0.41 & 0.71 & 0.46 \\
\hline Japan & - & - & - & 31.0 & 20.6 & 9.81 \\
\hline Russia & - & - & - & - & 0.09 & 0.12 \\
\hline US & - & - & - & 32.6 & 38.6 & 46.92 \\
\hline Five in total & - & - & - & 64.01 & 60.24 & 59.12 \\
\hline \multicolumn{7}{|l|}{ Net FDI } \\
\hline China & 0 & 0 & 5.12 & 5.46 & 40.27 & 10.39 \\
\hline India & 0.56 & 0.26 & 0.35 & 0.22 & 2.62 & 0.72 \\
\hline Japan & - & 0.21 & 0.78 & 0.51 & 0.01 & 0.34 \\
\hline Russia & - & - & - & 0 & 1.6 & 0.74 \\
\hline US & 6.83 & 28.6 & 21.5 & 18.1 & 15.6 & 16.59 \\
\hline Five in total & - & - & - & 24.29 & 60.1 & 28.78 \\
\hline \multicolumn{7}{|c|}{ Capital resources } \\
\hline China & 1.73 & 2.21 & 3.81 & 3.87 & 10.0 & 10.14 \\
\hline India & 1.74 & 1.50 & 2.16 & 2.0 & 2.7 & 2.22 \\
\hline Japan & 5.28 & 5.25 & 5.52 & 14.4 & 10.5 & 7.12 \\
\hline Russia & - & - & - & - & 1.5 & 2.27 \\
\hline US & 11.51 & 23.02 & 20.33 & 23.4 & 23.8 & 25.54 \\
\hline Five in total & - & - & - & 43.67 & 48.5 & 47.29 \\
\hline
\end{tabular}

Source: World Bank, World Development Indicators 2004 CD-ROM.

Notes: Gross capital formation consists of outlays on additions to the fixed assets of the economy plus net changes in the level of inventories. Fixed assets include land improvements (fences, ditches, drains, and so on); plant, machinery, and equipment purchases; and the construction of roads, railways, and the like, including schools, offices, hospitals, private residential dwellings, and commercial and industrial buildings. Inventories are stocks of goods held by firms to meet temporary or unexpected fluctuations in production or sales, and "work in progress." According to the 1993 SNA, net acquisitions of valuables are also considered capital formation.

Foreign direct investment is net inflows of investment to acquire a lasting management interest (10 percent or more of voting stock) in an enterprise operating in an economy other than of the investor. It is the sum of equity capital, reinvestment of earnings, other long-term capital, and shortterm capital as shown in the balance of payments. Gross capital formation (gross domestic investment in previous editions) is the sum of gross fixed capital formation, changes in inventories, and acquisitions less disposals of valuables.

Market capitalization of listed companies (also known as market value) is the share price times the number of shares outstanding.

The weighted average of the data for 1975-1985 is all calculated by 0.5 ; that of data for other years is calculated by capital resources $=0.4 \times$ domestic investment $+0.3 \times$ capital market +0.3 $\times$ net FDI; capital market refers to the market value of stocks (US dollar). 
Table 2.9 Knowledge and technology resources of five countries (1980-2000) (\% in world total)

\begin{tabular}{|c|c|c|c|c|c|}
\hline Country & 1980 & 1985 & 1990 & 1995 & 2000 \\
\hline \multicolumn{6}{|c|}{ Personal computers installed in education } \\
\hline China & & & 0.37 & 1.14 & 4.24 \\
\hline India & & & 0.2 & 0.5 & 0.97 \\
\hline Japan & & & 5.56 & 6.28 & 8.44 \\
\hline Russia & & & 0.38 & 1.08 & 1.32 \\
\hline US & & & 40.67 & 35.91 & 34.76 \\
\hline Five in total & & & 47.18 & 44.91 & 49.72 \\
\hline \multicolumn{6}{|c|}{ Patent applications residents } \\
\hline China & & & & $1.61(1996)$ & 2.82 \\
\hline India & & & & $0.23(1996)$ & 0.10 \\
\hline Japan & & & & 46.88 (1996) & 42.83 \\
\hline Russia & & & & $2.49(1996)$ & 2.61 \\
\hline US & & & & 15.39 (1996) & 19.34 \\
\hline Five in total & & & & $66.6(1996)$ & 67.69 \\
\hline \multicolumn{6}{|c|}{ Scientific and technical journal articles } \\
\hline China & 0.33 & 0.54 & $1.02(1989)$ & 1.42 & $2.21(1999)$ \\
\hline India & 3.49 & 2.69 & $2.28(1989)$ & 1.8 & $1.74(1999)$ \\
\hline Japan & 7.47 & 8.31 & $8.87(1989)$ & 9.04 & 9.05 (1999) \\
\hline Russia & & & & 3.93 & 2.96 (1999) \\
\hline US & 39.37 & 38.64 & 38.03 (1989) & 32.68 & 30.93 (1999) \\
\hline Five in total & & & & 48.87 & 46.89 (1999) \\
\hline \multicolumn{6}{|l|}{ Internet users } \\
\hline China & & & & 0.02 & 0.15 \\
\hline India & & & & 0.01 & 0.08 \\
\hline Japan & & & & 2.83 & 3.75 \\
\hline Russia & & & & 0.23 & 0.22 \\
\hline US & & & & 63.68 & 66.41 \\
\hline Five in total & & & & 66.77 & 70.61 \\
\hline \multicolumn{6}{|c|}{$R \& D$ expenditure } \\
\hline China & 1.25 & 1.34 & 1.67 & 2.53 & 4.69 \\
\hline India & 0.96 & 1.33 & 1.52 & 1.71 & 2.82 \\
\hline Japan & 8.99 & 10.02 & 11.51 & 11.59 & 9.44 \\
\hline Russia & & & & 1.07 & 1.10 \\
\hline US & 26.01 & 27.12 & 25.12 & 25.27 & 24.50 \\
\hline Five in total & & & & 42.17 & 42.55 \\
\hline \multicolumn{6}{|c|}{ Total technology resources in world total } \\
\hline China & 0.79 & 0.94 & 1.01 & 1.34 & 2.82 \\
\hline India & 2.23 & 2.01 & 1.23 & 0.85 & 1.14 \\
\hline Japan & 8.23 & 9.17 & 8.56 & 15.32 & 14.70 \\
\hline Russia & 0.00 & 0.00 & 0.08 & 1.76 & 1.64 \\
\hline US & 32.69 & 32.80 & 34.26 & 34.59 & 35.19 \\
\hline Five in total & & & 44.88 & 53.86 & 55.49 \\
\hline
\end{tabular}

Source: World Bank, World Development Indicators 2004 CD-ROM.

Notes: Scientific and technical journal articles refer to scientific and engineering articles published in the following fields: physics; biology; chemistry; mathematics; clinical medicine; bio-medical research; engineering and technology; and earth and space sciences.

Expenditures for R\&D are current and capital expenditures on creative, systematic activity that increases the stock of knowledge. Included are fundamental and applied research and experimental development work leading to new devices, products, or processes.

Patent applications filed are applications filed with a national patent office for exclusive rights for an invention - a product or process that provides a new way of doing something or offers a new technical solution to a problem. A patent provides protection for the invention to the owner of the patent for a limited period, generally twenty years.

The weighted average of the data for 1980 and 1985 is 0.5 that of data for 1990 is 0.33 ; that of data for 1995 and 1998 is 0.2 . 
of the planned economic model, thus greatly restricting innovation capabilities and labor productivity. That is why China is not a big power in terms of scientific innovation or in technological innovation.

Sixth, China is the lowest of the five major powers in terms of the percentage of governmental resources, and the percentage is dropping steadily (see Table 2.10). In 1980, China's expenditure on central finance made up only 1.84 percent of the world total, less than one-tenth of the United States, or 1.03 percent less than in 1995, barely half of India and Russia. In 2000, it was only 2.60 percent of the world total. The fiscal capabilities of the central government of China were barely one-sixth of the United States, far lower than the percentages of other types of resources in the world total. As a big populous power, China requires that the government should provide all kinds of public goods and services. As the biggest developing country, China requires that the government should invest in infrastructure and telecom facilities. As a country with the biggest regional disparities, the government should coordinate the development of different regions and promote the development of areas inhabited by national minorities. As the third largest country in terms of territorial land and seas and with a dozen neighbors that are still in a state of conflict, the government should have the necessary defense spending. Low fiscal capability cannot solve the above problems. This is the "fatal point" in China's strategic resources.

Seventh, China ranks first in terms of military personnel but it has a downward trend, dropping from 18.25 percent in 1985 to 11.32 percent in 2000 (see Table 2.11). According to the World Bank, China's military spending accounted for 11.50 percent of the world total while that of the United States accounted

Table 2.10 Governmental resources of five countries (1975-2000) (\% in world total)

\begin{tabular}{lcccccc}
\hline Country & 1975 & 1980 & 1985 & 1990 & 1995 & 2000 \\
\hline \multicolumn{7}{l}{ Central } \\
China & 13.66 & 14.74 & 8.87 & 5.42 & 3.41 & 6.01 \\
India & 10.95 & 12.25 & 15.18 & 15.96 & 14.48 & 16.70 \\
Japan & 14.72 & 18.38 & 17.23 & 15.70 & - & - \\
Russia & - & - & - & - & 25.37 & 22.9 \\
US & 21.01 & 22.02 & 24.14 & 23.49 & 22.64 & 19.2 \\
Five in total & 23.04 & 25.34 & 27.51 & 26.17 & 29.58 & 6.01 \\
Central government expenditure (\% of world total) & & & \\
China & 1.65 & 1.84 & 1.48 & 1.16 & 1.03 & 2.60 \\
India & 1.66 & 1.63 & 2.10 & 2.66 & 2.46 & 3.54 \\
Japan & 5.01 & 5.83 & 5.18 & 5.24 & 7.06 & 7.06 (a) \\
Russia & & & & & 2.60 & 2.33 \\
US & 20.7 & 19.1 & 19.0 & 18.7 & 15.9 & 16.13 \\
Five in total & & & & & 29.05 & 31.66 \\
\hline
\end{tabular}

Source: World Bank, World Development Indicators 2004 CD-ROM.

Notes: Central government expenditure includes both current and capital (development) expenditures and excludes lending minus repayments.

(a) Data of 1995 . 


\section{Economic and social transformation in China}

for 30.29 percent. China's military spending is only one-third that of the United States, twice as much as that of India and four times that of Japan. But according to Chinese official figures, China's military spending was only one-quarter that of the United States. What needs explaining is why China's military spending is relatively low and why the structure of the spending is extremely irrational, with 60-70 percent devoted to personnel and only very little to military technical equipment and R\&D. But the United States spends only 19 percent on personnel and 18 percent on procurement of military technical equipment and

Table 2.11 Military resources of five countries (1985-2000) (\% in world total)

\begin{tabular}{lrrrrr}
\hline Country & 1985 & 1990 & 1995 & 2000 & \\
\hline Military personnel & & & & & \\
China & 18.25 & 16.21 & 12.56 & 11.32 & $(1999)$ \\
India & 5.61 & 5.24 & 5.40 & 6.13 & $(1999)$ \\
Japan & 1.07 & 1.03 & 1.00 & 1.13 & $(1999)$ \\
Russia & & & 6.00 & 4.25 & $(1999)$ \\
US & 9.99 & 9.31 & 7.33 & 7.03 & $(1999)$ \\
Five in total & & & 32.29 & 29.86 & $(1999)$ \\
Military expenditures & & & & & \\
China & 4.84 & 5.31 & 7.69 & 11.50 & $(2001)$ \\
China (a) & 2.11 & 2.38 & 3.81 & 7.52 & $(2001)$ \\
India & 2.87 & 3.40 & 4.75 & 7.07 & $(2001)$ \\
Japan & 1.79 & 2.38 & 3.30 & 2.89 & $(2001)$ \\
Russia & & & 6.67 & 4.49 & $(2001)$ \\
US & 28.45 & 29.20 & 31.03 & 30.29 & $(2001)$ \\
Five in total & & & 53.44 & 52.26 & $(2001)$ \\
Military resources & & & & & \\
China & 10.20 & 9.67 & 9.64 & 11.43 & \\
China (a) & 8.57 & 7.91 & 7.31 & 9.04 & \\
India & 3.97 & 4.14 & 5.01 & 6.69 & \\
Japan & 1.50 & 1.84 & 2.38 & 2.19 & \\
Russia & - & - & 6.40 & 4.39 & \\
US & 21.07 & 21.24 & 21.55 & 20.99 & \\
Five in total & - & - & 44.98 & 43.30 & \\
\hline
\end{tabular}

Source: World Bank, World Development Indicators 2004 CD-ROM.

Notes: Military expenditures for NATO countries are based on the NATO definition, which covers military-related expenditures of the defense ministry (including recruiting, training, construction, and the purchase of military supplies and equipment) and other ministries. Civilian-type expenditures of the defense ministry are excluded. Military assistance is included in the expenditures of the donor country, and purchases of military equipment on credit are included at the time the debt is incurred, not at the time of payment. Data for other countries generally cover expenditures of the ministry of defense (excluded are expenditures on public order and safety, which are classified separately). Military personnel refer to active duty military personnel, including paramilitary forces if those forces resemble regular units in their organization, equipment, training, or mission.

Percentage of military resources in world total $=0.4 \times \%$ of military personnel in world total $+0.6 \times \%$ of military expenditure in world total.

(a) China's official statistics. Guojia tongjiju (National Bureau of Statistics of China), Zhongguo tongji nianjian 2004 (China Statistical Yearbook 2004), Beijing: Tongji chubanshe (China Statistics Press), 2004. 
14.2 percent on R\&D, and nearly 35 percent on maintaining combat readiness and executing military actions..$^{25}$

Eighth, China has limited capabilities in utilizing international resources. The percentage of international resources used by China is quite small in the world total, only 0.59 percent in 1980 , although it rose to 2.43 percent in 2000 (see Table 2.12). But that of the United States was 24.44 percent. Over the past twenty years, China's exports accounted for only 3.0-4.0 percent of the world total, while the spending on copyright and patents was only 1.73 percent of the world total. So, China is neither a software export power nor a software importer, failing to make full use of opening up to absorb global software technologies.

The preceding analysis shows that China's eight kinds of strategic resources in the world total are distributed extremely unevenly. It has advantages only in a single kind of strategic resources, but disadvantages in a number of other resources relative to those of the U.S. China enjoys a global strategic advantage in human capital and some advantages in natural resources and capital resources, but it has apparent disadvantages in knowledge and technological resources and in the utilization of international resources. The government has poor abilities in drawing in and operating finances, and still has a very weak "central government." Militarily, its strength is still not enough to cope with the military challenges of the forces advocating Taiwan's independence and the power politics of external hegemonies. Governmental resources and military resources still follow a downward trend. This reflects the unevenness in the development of different strategic resources and also the advantages and disadvantages of strategic resources. These have provided us with the basis for establishing the "grand strategy for the twenty-first century." The objectives of China's grand strategy should be to give full scope to the strategic advantages and turn strategic disadvantages into strategic advantages.

\section{Conclusions: aims of China's grand strategy}

Based on the preceding evaluation of strategic resources, we hold that the objectives of China's grand strategy should be to make the people rich and the country strong, that is, to constantly raise the percentage of its CNP in the world total so as to become a big world power by the middle of this century. The basic objectives of China's grand strategy in the future twenty years should be to include six goals: "high growth, great national power, an affluent people, national security, improvement of international competitiveness and sustainable development."

China will have quadrupled its gross economic volume by 2020, with the average annual GDP growth rate topping 7 percent from 2001 to 2020. In the meantime, China's GDP will be sixteen times as much as that of 1978 in terms of constant prices, one-fifth of the world total, while the per capita GDP will by then reach or approach the international level, making the country the world's biggest economic entity. In addition, trade growth will surpass economic growth, with China's trade volume making up about 10 percent of the world total and 
56 Economic and social transformation in China

Table 2.12 International resources of five countries (1980-2000) (\% in world total)

\begin{tabular}{|c|c|c|c|c|c|}
\hline Country & 1980 & 1985 & 1990 & 1995 & 2000 \\
\hline \multicolumn{6}{|c|}{ Exports of goods and services } \\
\hline China & 1.1 & 1.25 & 1.35 & 2.33 & 3.59 \\
\hline India & 0.49 & 0.57 & 0.54 & 0.63 & 0.77 \\
\hline Japan & 6.41 & 8.77 & 7.64 & 7.83 & 7.03 \\
\hline Russia & & & & 1.45 & 1.47 \\
\hline US & 11.85 & 12.86 & 12.65 & 12.58 & 13.52 \\
\hline Five in total & & & & 24.77 & 26.38 \\
\hline \multicolumn{6}{|c|}{ Imports of goods and services } \\
\hline China & 0.86 & 1.79 & 1.1 & 2.18 & 3.28 \\
\hline India & 0.75 & 0.85 & 0.74 & 0.82 & 0.88 \\
\hline Japan & 6.75 & 6.66 & 7.01 & 6.75 & 6.22 \\
\hline Russia & & & & 1.27 & 0.79 \\
\hline US & 12.51 & 18.03 & 14.52 & 14.34 & 18.32 \\
\hline Five in total & - & - & - & 25.37 & 29.49 \\
\hline \multicolumn{6}{|c|}{ Royalty and license fees receipts } \\
\hline China & 0 & 0 & 0 & 0 & 0.11 \\
\hline India & 0 & 0 & 0 & 0 & 0.11 \\
\hline Japan & 3.24 & 0 & 9.12 & 11.25 & 14.17 \\
\hline Russia & 0 & 0 & 0 & 0.01 & 0.13 \\
\hline US & 65.55 & 62.33 & 56.7 & 56.74 & 52.68 \\
\hline Five in total & & & & 68.00 & 67.20 \\
\hline \multicolumn{6}{|c|}{ Royalty and license fees payment } \\
\hline China & - & - & - & - & 1.73 \\
\hline India & 0.14 & 0.3 & 0.3 & 0.22 & 0.41 \\
\hline Japan & 14.77 & 22.08 & 18.75 & 18.78 & 14.86 \\
\hline Russia & - & - & - & 0.01 & 0.04 \\
\hline US & 10.26 & 11.38 & 13.04 & 13.8 & 21.74 \\
\hline Five in total & & & & & 38.79 \\
\hline \multicolumn{6}{|c|}{ International resources in world total } \\
\hline China & 0.59 & 0.91 & 0.74 & 1.35 & 2.43 \\
\hline India & 0.40 & 0.49 & 0.44 & 0.48 & 0.60 \\
\hline Japan & 7.55 & 9.05 & 9.97 & 10.38 & 9.78 \\
\hline Russia & 0.00 & 0.00 & 0.00 & 0.82 & 0.71 \\
\hline US & 22.47 & 24.01 & 22.10 & 22.18 & 24.44 \\
\hline Five in total & 31.01 & 34.45 & 33.25 & 35.22 & 37.96 \\
\hline
\end{tabular}

Source: World Bank, World Development Indicators 2004 CD-ROM.

Notes: Exports and imports of goods and services represent the value of all goods and other market services provided to, or received from, the rest of the world. They include the value of merchandise, freight, insurance, transport, travel, royalties, license fees, and other services, such as communications, construction, financial, information, business, personal, and government services. They exclude labor and property income (factor services in the 1968 SNA) as well as transfer payments.

Royalty and license fees are payments and receipts between residents and nonresidents for the authorized use of intangible, non-produced, non-financial assets and proprietary rights (such as patents, copyrights, trademarks, industrial processes, and franchises) and for the use, through licensing agreements, of produced originals of prototypes (such as manuscripts and films).

International resources $=0.3 \times$ (exports + imports $)+0.2 \times$ (copyright income + spending). 
the country jumping to the second major trading country from the present sixth.

In the coming twenty years, the relative gap between China's overall national strength and that of the United States will be reduced to two-fold from threefold, making the country a world power with dominant ability.

The per capita income level will see a constant improvement, rising from the current low-middle to the middle or above the middle level, while the life quality of the people will become noticeably better. The per capita schooling years and life expectancy will witness an overall enhancement. The human development index will reach a fairly high level from today's mediocre level. Absolute poverty will be eliminated from the population, and China will be built into a "Xiaokang" ("well-off") society of common prosperity.

National security and unification must be safeguarded. At the same time, defense and combat capability in high-technology conditions should be increased, and the mechanization and informationalization of the military should be completed so as to achieve a leapfrog development of military modernization.

By 2020 China's international competitiveness will have climbed from the present thirtieth to fourtieth placing to the world's top ten. By 2010 the population's natural growth rate will have been kept within 5 percent, and zero growth will be achieved by 2020. Forest coverage will reach 20 percent in 2010 and 23.4 percent in 2020 . Construction of safety nets for the prevention of all kinds of disaster will be intensified and the emergency management and aid system will be established. China's economic, social and science and technological development will enter its "prime time" in the next twenty years. By grasping this opportunity to speed up development, all the aforesaid goals will be realized.

China should intensify investment in various strategic resources, raise its percentage in the world total, give full scope to strategic advantages and turn strategic disadvantages into strategic advantages so as to become the strongest economic power in the world instead of just a big economic power and the world's big national power instead of just a regional big power.

First, to maintain a sustainable and steady economic growth to narrow the gap with the United States in terms of economic aggregate and outpace it in the 2015-2020 period, China must constantly raise the per capita income level, further improve the human development so that all the 1.5-1.6 billion people enjoy a better life, better ensure human security and a more beautiful ecological environment, and further eliminate the number of people in absolute poverty, thus realizing the objective of common prosperity. ${ }^{26}$ Second, it must further intensify investment in human capital to realize the objective of popularizing elementary education, accelerating the development of secondary and tertiary education, expanding vocational studies and training opportunities, energetically developing network education and remote education programs so as to build the world's biggest "learning society" with a lifelong learning system; and must establish a nationally unified labor market with more flexible and free choices, free movement and open competition in the labor market, fully utilizing the 
strategic advantages of human capital and turning them into sources of economic growth and economic wealth.

Third, it must develop new energy sources and renewable energy, to protect the land resources, to economize the use of water sources and fully utilize internationally available strategic resources based on market mechanisms and an environmentally friendly, sustainable development model.

Fourth, to accelerate the transition from investment-driven growth to knowledge and technology-driven growth, China should actively encourage and provide sufficient financial support to domestic knowledge and technological innovation, introduce low or zero tariffs on new technologies and equipment imported from other countries, and scrap non-tariff barriers, allowing domestic companies and citizens globally to make procurement of technologies and software, foreign language materials and books, encouraging foreign residents to apply for patents in China and streamlining patent application procedures.

Fifth, it must accelerate the reform of the financial system, standardize the capital market, and open up banking, insurance and securities markets to improve the direct financing and foreign financing sources of enterprises.

Sixth, to establish a public management and public finance system to improve the drawing capacity of the state, it must standardize fiscal receipts and incorporate extra-budgetary receipts into the budget, intensify tax collection so as to raise the fiscal receipts in the GDP from 15 percent to 20 percent in the near term and up to 25 percent in the middle term, and raise the central fiscal receipts (not including debt receipts) from 7.8 percent in the near term up to 12 percent and up to 15 percent in the middle term; it must accelerate the reform of the government, re-define the roles of the government in the market economy, introduce the information release system in fiscal receipts and expenditure, standardize the policy decision-making procedures on fiscal spending, introduce competition and the open bidding mechanism into government and public departments and raise the efficiency of fiscal expenditure.

Seventh, it must raise sharply the percentage of defense spending in GDP to enhance defense capabilities. The state should ensure that the armed forces are fed by the government, and it should be strictly forbidden to allow the armed forces to engage in business and profit making-taking activities, standardize defense spending and statistics and increase transparency. The defense spending in GDP should be raised to 2.0 percent in the near term and up to 2.5 percent in the middle term. It is necessary to cut non-military spending, improve combat capabilities and the abilities to cope with state crises; to accelerate the reforms of the military system, ending the drawbacks featuring "autarchy" in its external relations and "small but complete" in its internal relations; to introduce a new model of "open army building," expand social resources (technical, educational and human resources and infrastructure), raise the national defense mobilization capabilities and the capabilities of utilizing social resources, intensify and raise the military R\&D and expand its overflow to the society and build partnership relationship with civil research organizations for mutual complement; to further improve the wages and benefits of military personnel, open social 
security funds and personal retirement accounts for military personnel, introduce "training" of demobilized servicemen to prepared them for taking up civil jobs, establish an education and training fund for demobilized servicemen for re-education and special training to help them improve their competitiveness.

Eighth, China must intensify development and the use of soft forces while stressing the development of hard factors and raising the capabilities of operating strategic resources. CNP includes not only the hard factors but also the soft factors. It is of great importance to stress international institutions, international prestige, cultural influence and other soft factors in safeguarding state interests and in developing CNP. It is essential to come to grips with both hard and soft factors at the international level and grasp both of them firmly. That should be the key to China's grand strategy of the twenty-first century. 


\section{Why has China's TFP \\ dropped in 1995-2001? ${ }^{1}$}

China began to enter the economic takeoff stage around 1980 and has since maintained high economic growth for a good generation of people. The economic growth rate reached as high as 9.1 percent in 2003. Is China's economy overheated? Are China's investments overheated? There are two diametrically opposed views that have aroused extensive concerns and disputes at home and abroad. So we need to concentrate on the following problems: Can China sustain its high growth in the future? Can China realize high-quality and high-efficiency high growth? What are the sources of China's economic growth? What determines and affects China's economic growth? How will its economic growth pattern change? How should China transit from low-quality high-growth to highquality high-growth?

\section{Historical experience: TFP is the key to economic growth}

Studies at home and abroad show that China's economic growth has been higher following reform and opening up in that the Total Facts Productivity (TFP) has been rising sharply. ${ }^{2}$ After analysis, we have found that there are four sources for China's economic growth: (1) high growth of the labor force (2.6 percent); (2) high growth of capital stock (9.3 percent), but lower than the 11.5 percent from 1952 to 1978; (3) high growth of human capital, which is 2.2 percent if calculated by the number of years of education received by people above 15 years of age; (4) high growth of TFP, which has risen from -1.9 percent from 1952 to 1978 to 3.3-4.6 percent, calculated according to the weighted average of different capital or labor, and contributed to 33-47 percent of economic growth. The results of the calculation are fairly close to the conclusions arrived at by major studies in the world, such as the World Bank ${ }^{3}$ and Maddison. ${ }^{4}$

This has explained why high economic growth appeared at the beginning period of China's reform. Such growth is attributable mainly to TFP, which turned from negative to positive, rising by 5.2-6.5 percentage points, rather than capital growth, which dropped 2.2 percentage points. 


\section{Changes in the growth pattern in recent years: significant drop in TFP}

But such high growth and TFP growth did not continue. After 1995, major changes took place in the sources of economic growth. Up to the present, no Chinese or foreign scholars have given this problem any analysis and attention. The main reason for this is that when analyzing economic growth sources, the selection of either the 1978-1995 period or the 1978-1999 period all contain one important presumption, that the economic growth pattern after reform and opening up has basically remained unchanged, or did not change much to affect the long-term growth equation. We hold that this presumption is applicable only to the 1978-1995 period, but not to the period after 1995.

Economic growth (8.2 percent) from 1995 to 2001 was lower than the longterm potential growth (9.3-9.5 percent). Since that time, major changes have taken place in the sources of growth: (1) employment growth has dropped significantly, to only about 1.2 percent, giving rise to a situation characterized by high economic growth but low employment growth, indicating a drop in the ability to absorb labor; (2) high growth in capital stock (11.8 percent), 2.5 percentage points higher than in 1978-1995 or slightly higher than in 1952-1978 (11.5 percent). As a result, capital productivity (economic growth minus growth of capital stock) has turned from positive ( 0.5 percent $)$ to negative ( -3.6 percent), dropping by 4.1 percentage points, indicating a capital deepening process ${ }^{5}$ and the per capita capital growth reached as high as 10.6 percent, the fastest capital deepening process in the world, almost 4 percentage points higher than in the 1978-1995 period. This has given rise to substitution of capital for labor and capital excluding labor. (3) Human capital has grown by 2.8 percent: enrollment of senior secondary schools and tertiary schools has expanded, with the total enrollment in tertiary education ranking first in the world in 2003. (4) TFP dropped sharply by $2-3$ percentage points to about $0.3-2.3$ percent (calculated according to different weights of capital and labor). These show that the main sources of economic growth in the 1995-2001 period were capital input and low labor input. Both capital productivity and TFP dropped significantly.

What merits attention is the economic situation in 2003. GDP growth was 9.1 percent, close to the long-term growth potential (9.3-9.5 percent). Investment growth was 26.7 percent, far higher than the average growth (10.9 percent) in the 1979-2001 period. This shows that investment was already overheated. The authors estimate that the growth of capital stock over the year was 15.8 percent (depreciation factor taken into account), with the contribution to economic growth being about 6.3-9.5 percent (determined by weight of capital and labor). TFP growth dropped to 1.1 to -1.1 percent (see Table 3.1 ). It is estimated that the contribution by TFP for the whole year might be negative, similar to the planned economy period. This shows that, although economic growth in 2003 reached its potential growth, the economy as a whole was not overheated, but there was already overheated investment, with investment growth much higher than economic growth. This cannot produce a good investment effect; it can 
only lower sharply the capital productivity growth, estimated at about -6.7 percent. Economic growth is much lower than capital stock growth, lowering sharply the TFP growth. This is, obviously, a typical high-growth and highinvestment of low quality and low efficiency.

Of late, we have adopted the Malmquist indexing method to study the nonparameter frontier production function model and used it to analyze TFP growth during different periods since reform and found that TFP growth in 1979-1995 was 4.63 percent and it dropped to 0.60 percent in 1996-2001 (see Table 3.2).

The highest TFP appeared in 1978-1984 (7.65 percent) and the lowest was in 1996-2001 (see Figure 3.1). The results are identical with the calculation results. Then, we dissected the TFP growth into contribution by technical progress and contribution by technical efficiency and found that technical progress slowed and technical efficiency dropped in 1996-2001. ${ }^{6}$

This shows that China's economic growth in recent years is not realized by relying on technical progress and technical efficiency and investment efficiency, but by high growth of capital investment, a path characterized by low quality and high growth, with productivity dropping significantly. This is not a sustainable growth pattern. It is rather the price paid for overheated investment and

Table 3.1 Estimates of China's economic growth sources (1952-2003) (\%)

\begin{tabular}{lcllc}
\hline & $1952-1978$ & $1978-1995$ & $1995-2001$ & 2003 \\
\hline Population & 2.0 & 1.4 & 0.9 & 0.6 \\
GDP & 4.7 & 9.8 & 8.2 & 9.1 \\
Per capita GDP & 2.7 & 8.4 & 7.3 & 8.5 \\
Employment & 2.6 & 2.6 & 1.2 & 0.9 \\
Labor productivity & 2.1 & 7.2 & 7.0 & 8.2 \\
Capital stock & 11.5 & 9.3 & 11.8 & 15.8 \\
Human capital & 4.1 & 2.2 & 2.8 & 2.8 \\
Capital productivity & -6.8 & 0.5 & -3.6 & -6.7 \\
Capital stock per labor & 8.9 & 6.7 & 10.6 & 14.9 \\
TFP a & -1.9 & $4.64(47.3)$ & $2.28(27.8)$ & $1.11(12.2)$ \\
TFP b & & $3.95(40.3)$ & $1.30(15.9)$ & $0.27(3.0)$ \\
TFP c & -3.24 & $3.26(33.3)$ & $0.32(3.9)$ & $-1.12(-12.3)$ \\
\hline
\end{tabular}

Sources: Capital stock calculated at 1987 price from A. Hu and T. Liu, "Zhong mei ri yin guofang shili bijiao" (Comparison of Defense Capital Power among China, US, Japan, and India), Strategy and Management, vol. 6, 2003; Human capital from Ch. Li, "Renli ziyuan yu jingji fazhan diqu chaju yanjiu" (Study of Regional Gaps in Human Capital and Economic Development), Management master's degree paper at School of Public Policy and Management of Tsinghua University under supervision of Prof. Angang Hu; GDP, population and employment from Guojia tongjiju (National Bureau of Statistics of China), Zhongguo laodong tongji nianjian (Chinese Labor Statistical Yearbook), Beijing: Zhongguo tongji chubanshe (China Statistics Press), 2000 and Guojia tongjiju (National Bureau of Statistics of China), Zhongguo tongji zhaiyao 2004 (China Statistical Abstract 2004), Beijing: Zhongguo tongji chubanshe (China Statistics Press), 2004, pp. 38 and 42.

Notes: In calculating TFP, (a) weight of capital input is 0.4 , labor input is 0.3 , human capital input is 0.3 , (b) weight of capital input is 0.5 , labor input is 0.25 , human capital input is 0.25 , (c) weight of capital input is 0.6 , labor input is 0.2 , human capital input is 0.2 . Data in brackets are contributions by TFP to GDP growth. 
blind investment. If we continue along this path, the pressure on energy and environment will grow and it will not pay off. The challenges facing China's new government are not only to prevent big rises or falls in economic development, but to change the economic growth pattern and raise economic growth quality and efficiency in order to maintain the stability of the macro economy.

\section{Why has China's TFP dropped in 1995-2001?}

According to the assets accumulation, economic growth and welfare analytical framework visualized by the World Bank in its "Growth Quality," there are

Table 3.2 TFP growth and its components during different periods of economic reform in China (1979-2001)

\begin{tabular}{|c|c|c|c|c|c|c|c|c|c|}
\hline \multirow[t]{2}{*}{ Periods } & \multicolumn{2}{|c|}{ TFP growth } & \multirow[b]{2}{*}{ Var. } & \multicolumn{3}{|c|}{$\begin{array}{l}\text { Technical efficiency } \\
\text { change }\end{array}$} & \multicolumn{2}{|c|}{ Technical progre } & \multirow{2}{*}{$\begin{array}{l}\text { ess } \\
\text { Var. }\end{array}$} \\
\hline & Mean & Std & & Mean & Std & Var. & Mean & Std & \\
\hline 1979-1990 & 1.0494 & 0.0139 & 1.3274 & 0.9902 & 0.0112 & 1.1286 & 1.0605 & 0.0065 & 0.6133 \\
\hline 1991-2001 & 1.0185 & 0.0215 & 2.1092 & 0.9969 & 0.0131 & 1.3130 & 1.0216 & 0.0159 & 1.5527 \\
\hline 1979-1995 & 1.0463 & 0.0128 & 1.2197 & 0.9932 & 0.0113 & 1.1402 & 1.0542 & 0.0059 & 0.5600 \\
\hline 1996-2001 & 1.0060 & 0.0256 & 2.5414 & 0.9936 & 0.0138 & 1.3914 & 1.0124 & 0.0172 & 1.6992 \\
\hline 1979-1984 & 1.0765 & 0.0191 & 1.7766 & 0.9847 & 0.0139 & 1.4108 & 1.0938 & 0.0100 & 0.9110 \\
\hline 1985-1990 & 1.0222 & 0.0172 & 1.6801 & 0.9958 & 0.0162 & 1.6283 & 1.0272 & 0.0084 & 0.8200 \\
\hline 1991-1995 & 1.0372 & $0.023^{4}$ & 2.2566 & 1.0020 & 0.0225 & 2.2450 & 1.0354 & 0.0166 & 1.6028 \\
\hline $1596^{*}-2001$ & 1.0060 & $0.025 v$ & 2.5414 & 0.9936 & 0.0138 & 1.3914 & 1.0124 & 0.0172 & 1.6992 \\
\hline
\end{tabular}

Source: J. Zheng and A. Hu, "Zhongguo gaige shiqi shengji shengchanlu zengzhang bianhua de shizheng fenxi (1979-2001)" (Provincial Productivity Trend in China (1979-2001): Analysis and Policy Implications), China Studies Reports, 2004, Issue No. 1.

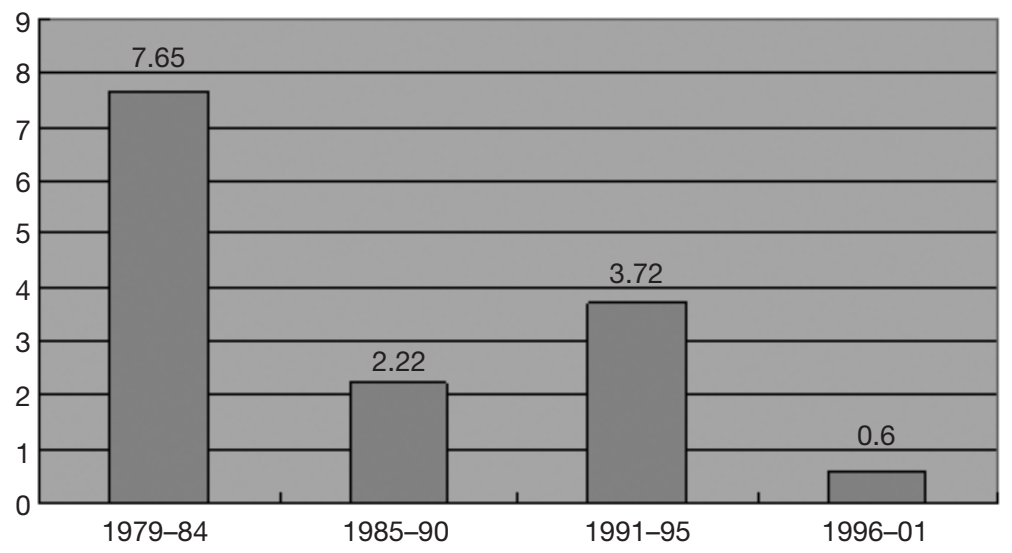

Figure 3.1 TFP growth in different periods (1979-2001)

Source: Calculation based on Table 3.2. 
three kinds of capital for stimulating development: tangible capital, human capital, and natural capital. Tangible assets make contributions to welfare through economic growth. Human capital makes contributions to growth and welfare by raising its gains, because investment in human capital investment, such as education, health and drinking water, increases the welfare of the people directly. Similarly, investment in natural capital is an important factor for improving the ecological environment and people's health and also an important part of the effort to improve the quality of life. However, excessive reliance on tangible assets or long-term implementation of distorted policies or inadequate investment in human capital and natural capital can also lower the growth of TFP. ${ }^{8}$

First of all, tangible capital has been excessively deepened; marginal returns of investment have dropped progressively; and the profit-taking of investment has inevitably dropped. Secondly, the country granted too many tax concession to foreign capital enterprises and provided disguised subsidies by leasing land, infrastructure facilities and energy at low prices, thus distorting the allocation of resources of tangible assets; thirdly, capital price (real interest rates on loans) is far lower than labor price (real wage growth and other welfare), encouraging firms to use more capital but less labor, to invest more tangible capital but less human capital. Since 1995, there appeared a sharp rise in the capital stock of state-owned enterprises. But it did not create new jobs. Instead, it created a large number of lay-offs. By the end of 2002, the number of on-the-job workers in state-owned and urban collective units was reduced by 60 million, more than the total population of France and equivalent to the reduction (22 million) of employment in the manufacturing of twenty major countries in the world from 1995 to 2002. Fourthly, enterprises and departments engaging in natural resources development possess a large amount of resource rents, giving the incentive to excessive development, thus reducing the efficiency of the utilization of resources. The coal output in 1996 was reduced from 1.4 billion tons to 1 billion tons by 2000 and rose a little to 1.5 billion tons by the first half of 2003, thus damaging the ecological environment. Fifthly, the income gap has been further enlarged, thus reducing the impact of economic growth on people's welfare. The World Bank report holds that China's income inequality is rapidly rising, from a level lower than that of India (Gini coefficient 0.20 ) to close to the level of the United States (Gini coefficient 0.40 in 1998 and in some cases 0.51 , after taking into consideration non-regular incomes). The poverty reduction brought about by a 1 percentage point increase in the total income of Chinese residents has dropped. ${ }^{9}$ Some scholars have discovered that the Gini coefficient of China increased by 1 percentage point every year from 1988 to 1995 , indicating a rapid polarization process. ${ }^{10}$ Dr. Lin Boqiang with the Asian Development Bank holds that this process has been accelerated by the policy of "letting part of the people get rich first" at the beginning of the reform, which marked the start of the rapid expansion of economic growth and polarization. He has discovered that the index of impoverished people in 1995-2001 was reduced by only 10 percent, but it was reduced by 18 percent in 1985-1990 (see Table 3.3 and Table 3.4). The degree of inequality in 1985 
was low (Gini coefficient 0.23), indicating that economic growth effectively reduced poverty. By 1995, the inequality situation got worse (Gini coefficient 0.33 ) and the effect of economic growth in reducing poverty also lowered markedly. ${ }^{11}$

Another World Bank study developed a pro-poor growth measuring method, which is not based on the average economic growth of a country, but on the income growth of poor people. The study found that China's average economic growth from 1990 to 1999 was quite different from the pro-poor growth. The average income growth of Chinese families was 7 percent, but the income growth of poor families was only 3 percent and the income growth of the wealthiest families was 11 percent. Although China's economic growth in the 1990s and the income growth of residents were the highest in the world, the pro-poor growth was only about 4 percent. ${ }^{12}$ Further, high governance costs and social trading costs have offset the efficiency and results of the utilization of the three major capitals. It did not create new wealth, but transferred wealth,

Table 3.3 Poverty indicators and Gini coefficient (1985-2001) (\%)

\begin{tabular}{lrrrr}
\hline & 1985 & 1990 & \multicolumn{1}{c}{1995} & \multicolumn{1}{c}{2001} \\
\hline Human Poverty Index (H) & 57.85 & 40.08 & 25.48 & 15.44 \\
Income gap (I) & 0.34 & 0.29 & 0.27 & 0.26 \\
Poverty gap (PG = H × I) & 19.00 & 11.76 & 6.89 & 3.43 \\
FGT & 8.37 & 4.75 & 2.56 & 1.03 \\
Gini coefficient & 0.23 & 0.29 & 0.33 & 0.35 \\
\hline
\end{tabular}

Source: B. Lin, "Zhongguo de jingji zengzhang, pinkun jianshao yu zhengce xuanze" (China's Economic Growth, Poverty Reduction and Policy Options), Jingji yanjiu (Economic Research Journal), 2003, Issue No. 12, 15-25.

Note: Poverty gap is the mean shortfall from the poverty line (counting the non-poor as having zero shortfall), expressed as a percentage of the poverty line. This measure reflects the depth of poverty as well as its incidence.

Table 3.4 Indicators for gauging poverty and changes in Gini coefficient (1985-2001) (\%)

\begin{tabular}{llll}
\hline & $1985-1990$ & $1990-1995$ & $1995-2001$ \\
\hline $\begin{array}{l}\text { Reduction ratio of poor } \\
\text { population indicator (H) }\end{array}$ & 17.77 & 14.60 & 10.04 \\
$\begin{array}{l}\text { Reduction ratio of income } \\
\text { shortage rate (I) }\end{array}$ & 0.05 & 0.02 & 0.01 \\
$\begin{array}{l}\text { Reduction of poverty shortage } \\
\quad \text { PG = H x I) }\end{array}$ & 7.24 & 4.87 & 3.46 \\
$\begin{array}{l}\text { Reduction ratio of FGT } \\
\text { Increase in Gini coefficient }\end{array}$ & 3.62 & 2.19 & 1.53 \\
GDP growth & 0.06 & 0.04 & 0.02 \\
\hline
\end{tabular}

Source: Same as for Table 3.3. 
thus reducing economic growth. For instance, the rents of the financial market reached 9 percent, thus increasing the actual cost of borrowing by enterprises and individual persons. ${ }^{13}$ The authors of this chapter have made an initial estimate of the four major types of corruption (rent-seeking, underground economic activities, tax drain, public investment and public spending) during the transitional period. In the latter half of the 1990s, the economic costs caused by the above four types of corruption averaged 13.3-16.9 percent of GDP. ${ }^{14}$ In the 1998-2002 period, the courts of the country cleared 41.88 million cases, averaging 326 per 10,000 people, 36 percent more than five years earlier. The number of civil and commercial cases cleared by courts at all levels reached 23.62 million, 20 percent more than five years earlier, with the total amount of money involved reaching 3197.1 billion Yuan, increasing by 2.4 times. ${ }^{15}$ The estimate by the authors of this chapter is equal to 7.2 percent of the total GDP of the period.

\section{Conclusions: China needs to adjust its approach to development and change its economic growth pattern}

Chinese leaders began to become aware of the problems of its economic growth pattern in the mid-1990s and clearly put forward objectives and a strategy for change. But in the latter half of the 1990s, China's economic growth was lower than the long-term growth potential, with TFP growth dropping markedly. When China was still in the lower-middle income stage, it was too early for the country to enter the capital deepening process, and it failed to make full use of its rich labor resources to more effectively develop labor-intensive industries. As a result, fewer and fewer jobs were created, leading to a peak in lay-offs and unemployment, and increasing inequality in income distribution, active rentseeking activities, and sharp rises in social cost. These not only affected economic growth, but also directly or indirectly affected the welfare of the people. This has also made economic growth that relies on capital input, energy consumption and pollution discharge unsustainable. It seems very important for the government to give up the traditional strategy of pursuing high economic growth and investment-driven growth and instead adopt a new strategy of pursuing the quality and efficiency of economic growth and productivity-driven growth. At the same time, China also needs to shift from low-employment growth to high-employment growth, from unfair growth to fair growth, and from unsustainable growth to sustainable growth and to further improve the quality of policies and the quality of the government in managing society. ${ }^{16}$ This is exactly the economic and social background for the new Chinese leadership to put forward the new "putting people first" approach to development. 


\section{From unevenness to coordination for China's regional development (1978-2004) $)^{1}$}

\section{Background}

China is now undergoing an in-depth economic development and social transition. Historically, except for China, no other country has ever achieved such a quick economic growth and such an extensive social transition with regard to such a huge population and within such a short period of time. In particular, since the beginning of the reform and opening up, China has already experienced three historic transitions: the first was from a traditional agricultural society to a modern industrial society (namely, industrialization); the second was from a centrally planned economy into a market-oriented one (namely, marketization); and the third is from a closed economy into an open one (namely, economic globalization). Many distortions and deficiencies existing under the previous planned economy have been gradually eliminated. Market force is now playing an increasingly important role in economic operations and decision-making.

Obviously, China has achieved unprecedented economic growth and enhanced its comprehensive national power. As statistical data show, the annual average growth rate of China's GDP reached 9.4 percent from 1979 to 2002, while during all of the 1980s and the first five years of the 1990s, this rate has even exceeded 10 percent. In 1996, China's GDP even equated to two-thirds of the economic aggregate of the rest of East Asia (exclusive of Japan), while in 2002, the comparable weight has grown to 1.2 times. In 2003, despite the negative influence of the SARS crisis and the slackening of world trade growth, China's GDP still kept climbing at a speed as high as 9.1 percent.

China is unique in the world as a large-sized developing country, featuring a huge population and broad territory. It is now also listed among those countries in the world that witness the biggest disparities in terms of physical geography, population resources, economic development and social development. We find that the relative variation coefficients of per capita GDP (in US dollars) and human development indicators among the 31 provinces, municipalities and autonomous regions have all turned out higher than those of all the other countries in the world. Nevertheless, one basic feature of contemporary China is significant regional disparities and remarkably uneven development. We summarize the real China as "One China, four worlds or groups."2 
The first world or group mainly comprises developed cities such as Beijing, Shanghai, and Shenzhen. The per capita income (PPP) of Shanghai and Beijing are US $\$ 15,516$ and US $\$ 9,996$ respectively, far higher than that of high/middleincome countries (US $\$ 8,320$ ), approximately 63.5 percent and 40.9 percent of that of high-income countries (US \$24,430), and ranking in forty-fifth and sixtyfourth places respectively among the 206 countries and regions in the world. The total population of Shanghai and Beijing occupies about 2.2 percent of the whole country. The second world or group is composed of large/middle sized cities and those high/middle-income regions in coastal areas, such as Tianjin, Guangdong, Zhejiang, Jiangsu, Fujian and Liaoning. The per capita GDPs of the above six provinces are all higher than the average level (US \$3,960) of middle/low-income countries, but lower than the average level of high/middleincome countries. The total population in the second group amounts to 274.04 million, making up approximately 21.8 percent of the country's total. The third world or group is low/middle-income regions, including Shandong, Hebei, Heilongjiang, and Jilin provinces. The per capita GDP of this group is lower than the average level of low/middle-income countries, ranking between 100th and 139th in the world. The total population in the third group is estimated to reach 337.83 million, taking up about 26.0 percent of the country's total. The fourth group comprises the poverty-stricken regions in central and western China, minority areas, rural areas, remote areas and other low-income areas. Specifically, the per capita GDP of Guizhou province is US \$1247, lower than the average level (US \$1790) of low-income countries, ranking the 177th place in the world. In addition, Gansu, Shanxi and Tibet rank the 157th, 155th and 152nd places respectively. About half of China's regions rank after 140th. The total population in the fourth group accounts for about 630 million, occupying half of the country's total.

In 2000, China reported a Gross National Income (GNI) of US \$3920 (PPP) which was classified as a low-middle income level in the world. But the GNI was still lower than the average level of low-middle income countries, and approximately 53 percent of the world average level of US \$7410. China features a coexistence of four development worlds or groups in terms of per capita income, but the underdeveloped worlds or groups (i.e. the third and fourth worlds or groups) are absolutely dominant, hosting about three-quarters of the country's population. Therefore, as a whole, China's economy in terms of per capita income still remains at a relatively low level in the world.

To gain a clearer insight into China's situation, it is necessary to pay more attention to the remarkable disparities of economic growth and social development among different provinces, rural and urban areas, and even different regions within the same province. Since the 1990s, unbalanced economic development across regions has become unprecedented, and regional disparities have already been viewed as one of the most serious barriers that hinder economic development, political reform and social stability in China. ${ }^{3}$ Therefore, how China realizes coordinated regional development has become a major issue in both academic researches and policy practices. 
Table 4.1 Per capita incomes and distribution in China (1999) (in US dollars, PPP)

\begin{tabular}{|c|c|c|c|c|}
\hline Region & $\begin{array}{l}\text { Per capita } \\
G D P \\
\text { (RMB Yuan) }\end{array}$ & $\begin{array}{l}\text { Per capita } \\
\text { GDP } \\
(U S \$)\end{array}$ & $\begin{array}{l}\text { Per capita } \\
G D P \\
(U S \$, P P P)\end{array}$ & $\begin{array}{l}\text { Global } \\
\text { ranking } \\
(U S \text { \& in PPP) }\end{array}$ \\
\hline National level & 6534 & 780 & 3291 & 128 \\
\hline Beijing & 19846 & 2369 & 9996 & 64 \\
\hline Tianjin & 15976 & 1907 & 8047 & 72 \\
\hline Hebei & 6932 & 828 & 3491 & 127 \\
\hline Shanxi & 4727 & 564 & 2381 & 144 \\
\hline Inner Mongolia & 5350 & 639 & 2695 & 141 \\
\hline Liaoning & 10086 & 1204 & 5080 & 98 \\
\hline Jilin & 6341 & 757 & 3194 & 131 \\
\hline Heilongjiang & 7660 & 914 & 3858 & 118 \\
\hline Shanghai & 30805 & 3677 & 15516 & 45 \\
\hline Jiangsu & 10665 & 1273 & 5372 & 92 \\
\hline Zhejiang & 12037 & 1437 & 6062 & 84 \\
\hline Anhui & 4707 & 562 & 2371 & 144 \\
\hline Fujian & 10797 & 1289 & 5438 & 92 \\
\hline Jiangxi & 4661 & 556 & 2348 & 146 \\
\hline Shandong & 8673 & 1035 & 4369 & 108 \\
\hline Henan & 4894 & 584 & 2465 & 143 \\
\hline Hubei & 6514 & 778 & 3281 & 129 \\
\hline Hunan & 5105 & 609 & 2571 & 142 \\
\hline Guangdong & 11728 & 1400 & 5907 & 87 \\
\hline Guangxi & 4148 & 495 & 2089 & 155 \\
\hline Hainan & 6383 & 762 & 3215 & 131 \\
\hline Chongqing & 4826 & 576 & 2431 & 144 \\
\hline Sichuan & 4452 & 531 & 2242 & 149 \\
\hline Guizhou & 2475 & 295 & 1247 & 177 \\
\hline Yunnan & 4452 & 531 & 2242 & 149 \\
\hline Tibet & 4262 & 509 & 2147 & 154 \\
\hline Shaanxi & 4101 & 490 & 2066 & 155 \\
\hline Gansu & 3668 & 438 & 1847 & 157 \\
\hline Qinghai & 4662 & 557 & 2348 & 146 \\
\hline Ningxia & 4473 & 534 & 2253 & 149 \\
\hline Xinjiang & 6470 & 772 & 3259 & 131 \\
\hline
\end{tabular}

Sources: Per capita GDP is from Guojia tongjiju (National Bureau of Statistics of China), Zhongguo tongji nianjian 2000 (China Statistical Yearbook 2000), Beijing: Zhongguo tongji chubanshe (China Statistics Press), 2000; Data in US \$ and PPP are author's calculation in reference to World Bank, World Development Report 2000/2001: Attacking Poverty, New York: Oxford University Press, 2000.

Notes: The global rank refers to the place of that province among 206 countries in the world.

\section{The historical trend of regional development disparities}

Many researches have conducted in-depth studies on the regional disparities of development in China. ${ }^{4}$ However, most of them focus only on the disparity of economic development, more specifically on a single indicator: per capita GDP. In fact, the imbalance and inequality of China's development is typically multidimensional. ${ }^{5}$ Accordingly, the disparity should also be reflected in multiple 
dimensions. This chapter intends to analyze the historical trend of regional disparities in terms of economic development, human development, social development, and knowledge development, so as to gain a clear and comprehensive insight into China's regional disparities. ${ }^{6}$

\section{Regional disparities of economic development}

This study has calculated the coefficients of relative variations across different regions in terms of per capita national income from 1952 to 1992, and has used the data of per capita GDP from 1978 to 1999 to get other coefficients like minimax coefficient, coefficient of relative variations, weighted coefficient of relative variations, convergence coefficient, and Theil index. Based on all of the analyzed results, we find that since the establishment of the People's Republic of China, the historical evolution of regional disparities of economic development can be classified into three phases:

Phase I (1952-1978): regional economic disparities were expanding in a fluctuant way

In fact, at the very beginning of the founding of China, China was already a country with a huge population, broad territory, and remarkable regional disparities in physical geography and economic development. All of these are the historical legacies that we inherited before launching industrialization, and also the initial conditions for pursuing economic development. After 1952, the regional disparities began to enlarge. For instance, the coefficient of relative variations in terms of real per capita income reached 136.58 percent in 1978.

Phase II (1978-1991): regional economic disparities kept converging

In 1978, the coefficient of relative variations in terms of per capita GDP was 97.4 percent, and kept decreasing after the adoption of reform and opening up. The same coefficient was 88.9 percent in 1985 , and reached the minimum of 81.9 percent in 1991. Other indicators, like weighted coefficient of relative variations, $\Sigma$ coefficient of per capita GDP, minimax coefficient, and Theil index, all followed a similar evolving trend. These five indicators all reached their minimal values in 1990 and 1991 respectively. In brief, the regional disparities reflected by different measures all showed similar evolving trends.

Phase III (1991-present): regional economic disparities began enlarging again

The coefficient of relative variations in terms of per capita real GDP climbed to 88.1 percent in 1995 , and further to 94.5 percent in 1999 , up by 12.6 percent over that in 1991 and close to that recorded in 1978 when China initially adopted 
its policy of reform and opening up. The weighted coefficient of relative variations rose to 74.1 percent. The minimax coefficient also surged up to 17.7 times in 1999 from only 11.6 times in 1991, much higher than that (14.3 times) posted in 1978. The Theil index kept climbing up in the 1990s, and reached 0.128 in 1999, far higher than that (0.105) in 1978. The $\Sigma$ coefficient of per capita GDP of all regions in 1999 was 0.599 , far higher than that $(0.553)$ in 1978. Among the five indicators concerning regional disparities, three reached a higher level in 1999 than in 1978, which indicates that the increment of regional disparities since the early 1990s has exceeded (or at least approached) the decrement in the 1980s. Now, the economic disparities among regions have expanded to the most serious level since the establishment of the PRC. In Figure 4.1 , the decrease in 2000 is due to the necessary adjustment of the population size by the National Census 2000, which increased the population base of several coastal developed regions. In fact, the regional disparities in the successive two years have kept expanding.

\section{Regional disparities of human development}

With respect to the Human Development Index (HDI), regional disparities still exist in modern China. According to UNDP, China's HDI was 0.726 in 2000, already comparable to the high/middle level of human development in the

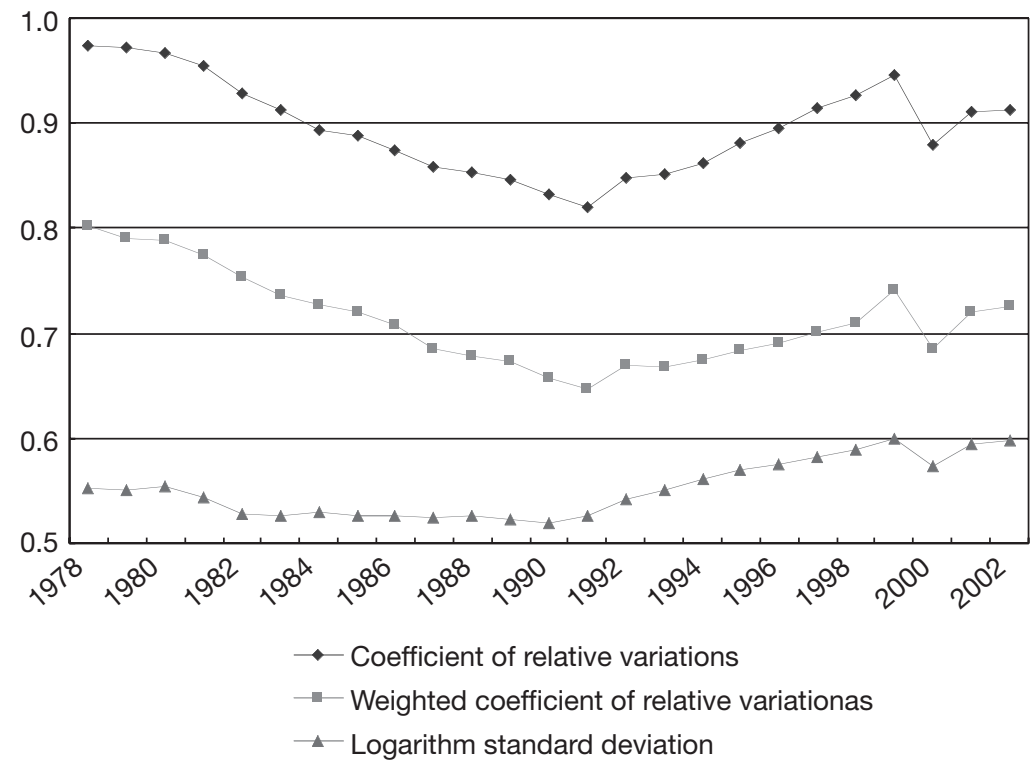

Figure 4.1 Relative regional disparities (per capita real GDP) since reform and opening up (1978-2002)

Notes: Calculation in 1978 fixed prices for all regions. 


\section{2}

world. ${ }^{7}$ In 1999, five western regions achieved HDIs between 0.650 and 0.500 , belonging to the middle/low level of human development. Twenty-three regions recorded HDIs between 0.800 and 0.650 , equating to the high/middle level of human development. Each of the three municipalities (Shanghai, Beijing and Tianjin) achieved an HDI of more than 0.800 , reaching the high level of human development. In addition, five regions in western China have not arrived at the high/middle level of human development yet; and fifteen central and western regions have all been ranked after the 100th place, in terms of HDI, among 174 countries and regions in the world. At the same time, we also find that those regions with relatively lower HDI ranks in 1995 have achieved much higher positions in 1999, which presents obvious "catch-up effects" (see Table 4.2). It must be pointed out that the ranking positions of China's regions have all turned out higher, to different degrees, on the global list of HDI than on the global list of per capita GDP. Two reasons can explain such a phenomenon: first, the sample sizes are different, 174 for HDI and 206 for per capita GDP respectively; secondly, the regional disparities in terms of human development are narrower than those in terms of per capita income.

The "Human Development Report 1997" listed three countries in the world which featured remarkable regional disparities in terms of the Human Poverty Index (HPI) (see Table 4.3). Among the three countries, China ranked in the first place, followed by Brazil and India. In China, the HPI of coastal regions was 0.18, while that of Beijing turned out less than 0.10, equating to those countries with extremely low HPI, like Chile and Singapore which ranked in the fifth place among 78 developing countries. However, the HPI of those western regions in China reached up to 0.44 and that of Guizhou province was about 0.55 , equating to those countries with rather high HPI, like Mali that ranked the last but five among 78 developing countries.

In China, the poverty-stricken population in rural areas is not evenly distributed throughout its territory, but mainly congregates in the provinces and autonomous regions in western China and those isolated regions with extremely stagnant economic growth. Most of these regions are geographically remote, lack human and natural resources, and have weak economic links with other regions. A majority of the poverty-stricken population in rural areas of China lives in mountainous regions. Some others are scattered in those counties with better physical conditions, but which have been exposed to low education, poor healthcare and arid land resources (even degeneration in some places). According to the latest analysis conducted by the National Bureau of Statistics of China (see Table 4.4), the low-income population living in urban areas of China is 25.1 million people, while that living in rural areas totals 90.29 million people. Hence, the total low-income population in China amounts to 115.39 million people. Among them, 78 percent live in rural areas, while 85 percent live in central and western China. Furthermore, the low-income population living in urban areas of central China accounts for 51.3 percent of the country's total, while that living in western China reaches 54.4 percent of the country's total. 


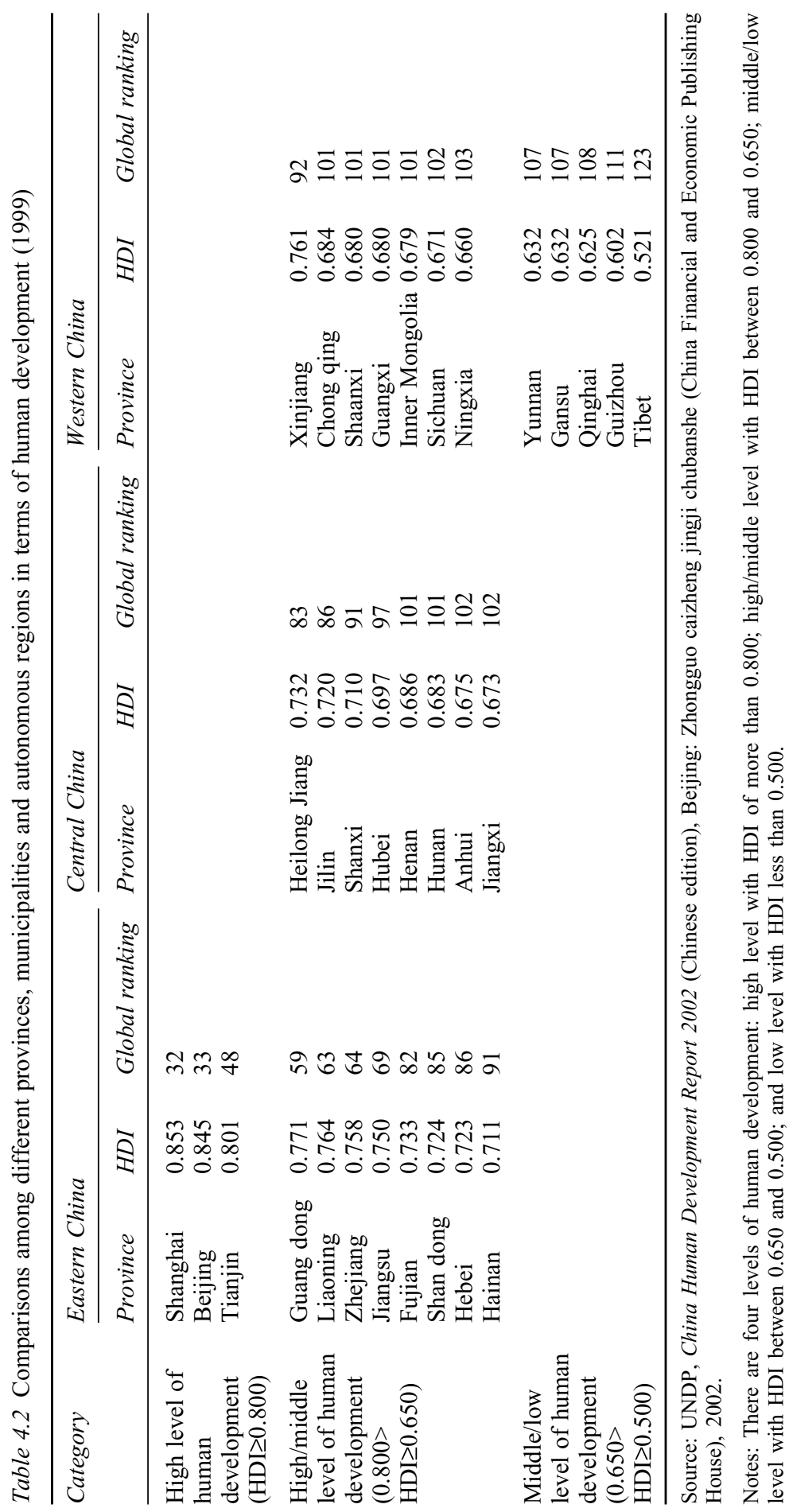




\section{Economic and social transformation in China}

Table 4.3 Human risk indices of regions in eastern, western and central China (1999)

\begin{tabular}{|c|c|c|c|}
\hline Human risk index & Eastern China & Central China & Western China \\
\hline $\begin{array}{l}\text { Low human risk } \\
(\mathrm{HRI}<0.250)\end{array}$ & $\begin{array}{l}\text { Shanghai }(0.186) \\
\text { Beijing }(0.231) \\
\text { Jiangsu }(0.241)\end{array}$ & & \\
\hline $\begin{array}{l}\text { High/middle } \\
\text { human risk } \\
(0.500>\text { HRI } \geq 0.250)\end{array}$ & $\begin{array}{l}\text { Fujian }(0.263) \\
\text { Liaoning }(0.266) \\
\text { Guangdong }(0.266) \\
\text { Hebei }(0.269) \\
\text { Tianjin }(0.270)\end{array}$ & $\begin{array}{l}\text { Hunan }(0.273) \\
\text { Jilin }(0.292) \\
\text { Anhui }(0.297) \\
\text { Hubei }(0.298) \\
\text { Heilongjiang }(0.299)\end{array}$ & $\begin{array}{l}\text { Xinjiang }(0.264) \\
\text { Inner Mongolia }(0.282) \\
\text { Sichuan }(0.312) \\
\text { Shaanxi }(0.334) \\
\text { Qinghai }(0.335)\end{array}$ \\
\hline $\begin{array}{l}\text { Middle/low } \\
\text { human risk } \\
(0.750>\text { HRI } \geq 0.500)\end{array}$ & $\begin{array}{l}\text { Hainan }(0.278) \\
\text { Shandong }(0.290) \\
\text { Zhejiang }(0.367)\end{array}$ & $\begin{array}{l}\text { Jiangxi }(0.327) \\
\text { Shanxi }(0.340) \\
\text { Henan }(0.466)\end{array}$ & $\begin{array}{l}\text { Guangxi }(0.346) \\
\text { Yunnan }(0.415) \\
\text { Gansu }(0.418) \\
\text { Guizhou }(0.519) \\
\text { Ningxia }(0.555)\end{array}$ \\
\hline $\begin{array}{l}\text { High human risk } \\
(\mathrm{HRI} \geq 0.750)\end{array}$ & & & Tibet $(0.745)$ \\
\hline
\end{tabular}

Source: UNDP, China Human Development Report 2002; authors' calculation based on related information.

Notes: The human risk index is a compound indicator worked out based on the malnutrition index, air pollution index, water pollution index, etc. This index can manifest the quality of life and the degree of execrableness of living environment in a certain region.

Table 4.4 Geographical distribution of low-income population living in rural and urban areas in China

\begin{tabular}{|c|c|c|c|c|c|c|}
\hline & \multicolumn{3}{|c|}{$\begin{array}{l}\text { Low-income population } \\
\text { in urban areas }\end{array}$} & \multicolumn{3}{|c|}{$\begin{array}{l}\text { Low-income population } \\
\text { in rural areas }\end{array}$} \\
\hline & $\begin{array}{l}\text { Population } \\
\text { size } \\
\text { (million) }\end{array}$ & $\begin{array}{l}\text { Proportion } \\
\text { in the } \\
\text { country's } \\
\text { total (\%) }\end{array}$ & $\begin{array}{l}\text { Proportion } \\
\text { in the total } \\
\text { population } \\
\text { living in } \\
\text { urban areas } \\
\text { of China } \\
\text { (\%) }\end{array}$ & $\begin{array}{l}\text { Population } \\
\text { size } \\
\text { (million) }\end{array}$ & $\begin{array}{l}\text { Proportion } \\
\text { in the } \\
\text { country's } \\
\text { total (\%) }\end{array}$ & $\begin{array}{l}\text { Proportion } \\
\text { in the total } \\
\text { population } \\
\text { living in } \\
\text { rural areas } \\
\text { of China } \\
(\%)\end{array}$ \\
\hline Whole Country & 25.10 & 100.0 & 8.1 & 90.29 & 100.0 & 9.8 \\
\hline China's east & 4.97 & 19.8 & 3.8 & 12.55 & 13.9 & 3.3 \\
\hline China's center & 12.88 & 51.3 & 11.7 & 28.67 & 31.8 & 8.9 \\
\hline China's west & 7.25 & 28.9 & 10.2 & 49.08 & 54.4 & 21.8 \\
\hline
\end{tabular}

Source: Guojia tongjiju (National Bureau of Statistics of China), Zhongguo fazhan baogao 2003 (China Development Report 2003), Beijing: Zhongguo tongji chubanshe (China Statistics Press), 2003, pp. 189-190.

Notes: Low-income population refers to those residents whose per capita consumption expenditure level falls below that of the lowest income group (20\%). Residents below such a standard are able to have nothing more than their basic needs of existence satisfied, while their per capita consumption expenditure usually equates to one-third of the consumption expenditure level, and their expenditure in food takes up more than $50 \%$ of their total consumption expenditure. 
Lately, UNDP's “China Human Development Report 2002” studied the healthcare service accessibility indices of different regions in China (see Table 4.5). Those western regions reported poor accessibility to healthcare services and relatively low sanitary conditions. This report also put forward a human risk index. In such a region as Tibet, despite little environmental pollution, other indices turned out at a rather poor level.

\section{Regional disparities of social development}

Globally, China is a typical country with remarkable regional disparities in terms of not only economic development, but also social development. By selecting and employing multiple social development indicators, we are able to comprehensively evaluate the degrees and possible regional disparities of social development, social progress, social fairness, and the availability of public service. The selected social development indicators include population development indicators, educational development indicators, scientific and technological development indicators,

Table 4.5 Healthcare service accessibility indices for different regions in eastern, central and western China (1999)

\begin{tabular}{|c|c|c|c|}
\hline $\begin{array}{l}\text { Healthcare service } \\
\text { accessibility index }\end{array}$ & Eastern China & Central China & Western China \\
\hline $\begin{array}{l}\text { Regions with a } \\
\text { high accessibility } \\
\text { of healthcare } \\
\text { service }(\mathrm{CSAI}<0.25)\end{array}$ & $\begin{array}{l}\text { Beijing }(0.06) \\
\text { Shanghai }(0.12) \\
\text { Tianjin }(0.22)\end{array}$ & & \\
\hline $\begin{array}{l}\text { Regions with a } \\
\text { high/middle } \\
\text { accessibility of } \\
\text { healthcare service } \\
(0.50>\text { CSAI } \geq 0.25)\end{array}$ & $\begin{array}{l}\text { Hebei }(0.27) \\
\text { Liaoning }(0.27) \\
\text { Fujian }(0.47) \\
\text { Jiangsu }(0.47)\end{array}$ & $\begin{array}{l}\text { Jilin }(0.36) \\
\text { Heilongjiang }(0.38) \\
\text { Shanxi }(0.43)\end{array}$ & $\begin{array}{l}\text { Qinghai }(0.37) \\
\text { Xinjiang }(0.39) \\
\text { Inner Mongolia }(0.43) \\
\text { Ningxia }(0.46) \\
\text { Yunnan }(0.46)\end{array}$ \\
\hline $\begin{array}{l}\text { Regions with a } \\
\text { middle/low } \\
\text { accessibility of } \\
\text { healthcare service } \\
(0.75>\text { CSAI } \geq 0.50)\end{array}$ & $\begin{array}{l}\text { Shandong }(0.50) \\
\text { Guangdong }(0.50) \\
\text { Hainan }(0.56)\end{array}$ & $\begin{array}{l}\text { Jiangxi }(0.50) \\
\text { Henan }(0.51) \\
\text { Hubei }(0.52) \\
\text { Hunan }(0.53) \\
\text { Anhui }(0.54)\end{array}$ & $\begin{array}{l}\text { Guangxi }(0.50) \\
\text { Gansu }(0.52) \\
\text { Shaanxi }(0.53) \\
\text { Sichuan }(0.60) \\
\text { Guizhou }(0.72)\end{array}$ \\
\hline $\begin{array}{l}\text { Regions with a } \\
\text { low accessibility of } \\
\text { healthcare service } \\
(\mathrm{CSAI} \geq 0.75)\end{array}$ & Zhejiang (0.76) & & Tibet (0.91) \\
\hline
\end{tabular}

Source: UNDP, China Human Development Report 2002; authors' calculation based on related information.

Notes: The healthcare service accessibility index is a compound indicator worked out on the basis of the number of sickbeds possessed by every 1,000 people, number of doctors and assistant doctors possessed by every 1,000 people, number of senior nurses and nurses possessed by every 1,000 people, and the percentage (\%) of those, in the total population, who have access to sickbeds, and services provided by doctors and nurses in hospitals. This index can manifest the level of healthcare service skills in a certain region. 
cultural development indicators, sanitary development indicators, and environmental development indicators. In order to evaluate the development levels of social service in different regions of China, we try to comprehensively explore each of the preceding social indicators.

By investigating social development indicators (such as population, education, sanitation, science and technology, culture, environmental pollution and infrastructure), we find that regional disparities, either relatively or absolutely, exist to different degrees in China. At either a national level or per capita level, China has already reached the middle social development level in today's world, and a few coastal regions have even measured up to the high international level. However, many inland regions still remain on rather low levels in comparison to the world. The relative regional disparities in terms of the major social development indicators have appeared quite large. The coefficients of relative variations of major development indicators in terms of population, education, sanitation, and culture (except for books and magazines per capita) turn out much lower than those of per capita GDP in the same periods. The coefficients of relative variations of scientific and technological indicators (except for the number of approved patents per every 1,000 people) and environmental indicators are lower than those of per capita GDP. The coefficients of relative variations of major infrastructure indicators (except for per capita electricity) are higher, or much higher, than those of per capita GDP. In brief, most regional disparities of social development are smaller than those of economic development.

For different social development indicators, the relative regional disparities have evolved inconsistently since the beginning of reform and opening up, sometimes narrowing, remaining unchanged or enlarging slightly. Taking population indicators as an example, the total fertility rate, birth rate, mortality rate, and natural growth rate have all been lower than the world's average levels, thus ranking China at the top of developing countries. Since the beginning of reform and opening up, the regional disparities in terms of total fertility rate and mortality rate have been declining, but those in terms of birth rate and natural growth rate have been rising in a fluctuant way. In those economically underdeveloped regions, the total fertility rate, birth rate, mortality rate, and natural growth rate have all remained on a relatively high level. What is more, these regions also lag behind in terms of human development. In China, the total fertility rate was 2.58 in 1981, and dropped down to 2.31 in 1990. Remarkable gaps still exist between these regions and the developed regions. The birth rate of the country was 33.43 per thousand in 1970, dropped down to 18.21 per thousand in 1980 , later climbed up slightly to 21.06 per thousand in 1990, and kept descending throughout the 1990s. Finally in 1999, the birth rate dropped to the lowest level of 15.23 per thousand since the beginning of reform and opening up. This birth rate is lower than not only the world's average level, but also the national level of developing countries reporting high human development indicators. Specifically, the birth rates of nine provinces (including Shanghai, Beijing, Tianjin, Liaoning, Jilin, Zhejiang, Jiangsu, Shandong and Hunan) have fallen below the average level of industrialized countries. As a 
matter of fact, China is a country with a relatively low birth rate. The birth rate is low in developed regions, while it definitely remains high in underdeveloped regions. The regional disparities in terms of birth rate have been expanding in a fluctuant way. The coefficients of relative variations of birth rate were 23.29 percent in $1980,22.48$ percent in 1985 , and 20.27 percent in 1990. In the 1980s, this coefficient kept descending linearly. In 1995, the same coefficient climbed up to 27.7 percent, and even reached 30.3 percent in 1999 , reaching a peak value during the past 25 years.

In brief, among the coefficients of relative variations of thirty-one social development indicators in eight main categories, twenty-one indicators have descended, seven have ascended, and the other three have only undergone slight changes (see Table 4.6). This indicates that the coefficients of relative variations in terms of most social development indicators have been descending, and also indicates that since the adoption of reform and opening up, the regional disparities in terms of accessibility of public services have been narrowed to different degrees.

\section{Regional disparities of knowledge development}

Knowledge is the most important factor in economic development and social transition today. Knowledge creates wealth, promotes development and facilitates reform. Knowledge resources are the most important resources of a country or region for driving its economic development. For underdeveloped countries and regions, the low knowledge development level is the biggest bottleneck to economic development. ${ }^{8}$

It is demonstrated by many researches that regional disparities are also reflected in the dimension of knowledge development (see Table 4.7). In order to conduct quantitative analysis on the regional disparities of knowledge capability, we set up an Evaluation Framework of Comprehensive Knowledge Capability, and calculated the indices of comprehensive knowledge capability for different regions. By investigating these indices, we can see that the distribution of knowledge resources in China is extremely unbalanced, and the resulting index for eastern China turns out much higher than that for central and western China. All those regions whose knowledge capabilities are at a high or high/middle level are nestled in eastern China. However, the knowledge capabilities in central and western China all remain at a low level, except that Jilin, Hubei, Heilongjiang and Shaanxi provinces lie at a middle/low level. In some regions and minority areas of western China, certain groups of people are faced with the risk of knowledge division. In fact, the regions in western China suffer the most insufficient knowledge resources and the largest knowledge developing disparities, which have already become a bottleneck hindering their further development.

By analyzing and comparing the preceding indicators, we can see that China has already reached the middle/low-income level and the high/middle human development level, the consumption structure has undergone unprecedented 
Table 4.6 Coefficients of relative variations for different regions in terms of major economic and social development indicators (1978-1999)

\begin{tabular}{|c|c|c|c|c|c|c|c|}
\hline Indicators & 1978 & 1980 & 1982 & 1985 & 1990 & 1995 & 1999 \\
\hline \multicolumn{8}{|l|}{ Economic indicators } \\
\hline $\begin{array}{l}\text { Per capita GDP } \\
\text { (Yuan) (a) }\end{array}$ & 97.2 & 96.8 & 96.2 & 87.5 & 83.0 & 88.2 & 94.5 \\
\hline $\begin{array}{l}\text { Per capita government } \\
\text { revenue (Yuan) }\end{array}$ & 186.3 & 200.0 & 200.0 & 170.0 & 102.8 & 91.5 & 98.8 \\
\hline $\begin{array}{l}\text { Per capita government } \\
\text { expenditure (Yuan) (a) }\end{array}$ & 68.8 & 59.5 & 70.3 & 55.8 & 52.2 & 65.9 & 74.5 \\
\hline $\begin{array}{l}\text { Per capita Gross Domestic } \\
\text { Investment (Yuan) (a) }\end{array}$ & 74.7 & 88.8 & 94.4 & 103.0 & 112.3 & 121.5 & \\
\hline \multicolumn{8}{|l|}{ Population indicators } \\
\hline Birth rate $(\%)$ & 23.5 & 23.3 & 16.3 & 22.5 & 20.3 & 29.1 & 30.3 \\
\hline Death rate $(\%)$ & 14.9 & 14.8 & 17.0 & 20.4 & 11.4 & 13.3 & 10.4 \\
\hline $\begin{array}{l}\text { Natural growth rate } \\
\text { of population (\%o) }\end{array}$ & 33.4 & 34.9 & 22.4 & 31.1 & 28.0 & 46.3 & 54.0 \\
\hline Total fertility rate & & & 31.3 & & 26.8 & & \\
\hline \multicolumn{8}{|l|}{ Educational indicators } \\
\hline $\begin{array}{l}\text { Enrollment rate of } \\
\text { school-age children }(\%)\end{array}$ & 3.7 & 5.4 & 7.9 & 11.1 & 6.8 & 7.2 & \\
\hline $\begin{array}{l}\text { Percentage of graduates } \\
\text { of primary schools } \\
\text { entering junior secondary } \\
\text { schools }(\%)\end{array}$ & 9.9 & 15.9 & 21.1 & 20.2 & 14.9 & 8.9 & \\
\hline $\begin{array}{l}\text { Percentage of graduates of } \\
\text { junior secondary schools } \\
\text { entering senior secondary } \\
\text { schools }(\%)\end{array}$ & 32.7 & 32.9 & 34.6 & 30.9 & 40.6 & 33.9 & \\
\hline \multicolumn{8}{|l|}{ Health development indicators } \\
\hline $\begin{array}{l}\text { Number of doctors per } \\
1,000 \text { people }\end{array}$ & 51.1 & 52.5 & 52.2 & 52.8 & 49.3 & 47.3 & 37.3 \\
\hline $\begin{array}{l}\text { Number of hospital beds } \\
\text { per } 1,000 \text { people }\end{array}$ & 36.9 & 31.7 & 37.9 & 32.9 & 36.9 & 38.6 & 34.9 \\
\hline $\begin{array}{l}\text { Incidence of diseases rate } \\
\text { from infectious disease to } \\
\text { be reported by laws }(\%)\end{array}$ & & 65.0 & & & 36.8 & 36.4 & \\
\hline \multicolumn{8}{|c|}{ Science and technological (S\&T) indicators } \\
\hline $\begin{array}{l}\text { Number of persons } \\
\text { engaged in scientific and } \\
\text { technological activities } \\
\text { per } 1,000 \text { people }\end{array}$ & & & & 84 & 77 & 54.6 & \\
\hline $\begin{array}{l}\text { Number of workers and } \\
\text { staff members engaged } \\
\text { in scientific and } \\
\text { technological activities }\end{array}$ & & & & 20.9 & 19.0 & 17.1 & \\
\hline $\begin{array}{l}\text { Total patents granted to } \\
\text { residents per } 1,000 \text { people }\end{array}$ & & & & 164.5 & 154.7 & 149.9 & 122.8 \\
\hline $\begin{array}{l}\text { Total patents granted per } \\
10,000 \mathrm{~S} \& \mathrm{~T} \text { personnel }\end{array}$ & & & & & 57.1 & 71.0 & \\
\hline
\end{tabular}


Table 4.6 continued

\begin{tabular}{|c|c|c|c|c|c|c|c|}
\hline Indicators & 1978 & 1980 & 1982 & 1985 & 1990 & 1995 & 1999 \\
\hline \multicolumn{8}{|c|}{ Cultural development indicators } \\
\hline $\begin{array}{l}\text { Per capita number of } \\
\text { newspapers }\end{array}$ & & 65.8 & & & 61.7 & 62.1 & \\
\hline Per capita printed sheets & & 76.5 & & & 100.7 & 106.1 & 75.5 \\
\hline Radio coverage rate $(\%)$ & & 39.4 & & & 24.3 & 15.2 & \\
\hline TV coverage rate $(\%)$ & & 44.9 & & & 16.0 & 11.0 & \\
\hline \multicolumn{8}{|l|}{ Environmental indicators } \\
\hline $\begin{array}{l}\text { Volume of solid industrial } \\
\text { waste (10,000 tons/ } \\
100 \text { million Yuan) (a) }\end{array}$ & & & & 66.8 & 59.0 & 63.1 & \\
\hline $\begin{array}{l}\text { Volume of waste water } \\
\text { discharge ( } 10,000 \text { tons/ } \\
100 \text { million Yuan) (a) }\end{array}$ & & & & 37.4 & 36.6 & 32.5 & \\
\hline $\begin{array}{l}\text { Volume of waste gas } \\
\text { emission ( } 100 \text { million } \\
\text { cu. m meters/100 million } \\
\text { Yuan) (a) }\end{array}$ & & & & 51.3 & 46.6 & 51.8 & \\
\hline \multicolumn{8}{|l|}{ Infrastructure indicators } \\
\hline $\begin{array}{l}\text { Per capita electricity } \\
\text { production (kilowatt- } \\
\text { hour/person) }\end{array}$ & 105.8 & 92.8 & 89.5 & 82.8 & 67.8 & 55.9 & \\
\hline $\begin{array}{l}\text { Length of highways per } \\
\text { million people }\end{array}$ & 120.4 & 144.1 & 141.8 & 132.3 & 124.2 & 114.3 & \\
\hline $\begin{array}{l}\text { Length of railways per } \\
\text { million people }\end{array}$ & 74.0 & 81.6 & 76.3 & 104.6 & 107.6 & 110.1 & \\
\hline $\begin{array}{l}\text { Mileage of navigable } \\
\text { inland waterways per } \\
\text { million people }\end{array}$ & 71.9 & 84.8 & 85.4 & 82.3 & 88.3 & 84.2 & \\
\hline $\begin{array}{l}\text { Number of telephone sets } \\
\text { owned per } 100 \text { people }\end{array}$ & 83.7 & 80.9 & 81.6 & 87.7 & 96.1 & 89.7 & 77.3 \\
\hline $\begin{array}{l}\text { Business volume of postal } \\
\text { and telecommunications } \\
\text { service (million) a }\end{array}$ & 140.6 & 135.3 & 113.7 & 122.5 & 130.6 & 110.3 & \\
\hline \multicolumn{8}{|c|}{ Human development indicators } \\
\hline \multicolumn{2}{|c|}{$\begin{array}{l}\text { Average years of school of } \\
\text { people aged } 15 \text { and } \\
\text { above (years) }\end{array}$} & & 24.3 & & 20.6 & 19.7 & 16.4 \\
\hline Adult literacy rate $(\%)$ & & & 9.5 & & 9.2 & 8.3 & 13.1 \\
\hline $\begin{array}{l}\text { Life expectancy at birth } \\
\text { (years) }\end{array}$ & & & 5.1 & & 5.2 & & \\
\hline Human development index & & & 9.0 & & 10.2 & & \\
\hline
\end{tabular}

Source: A. Hu and P. Zou, Shehui yu fazhan: woguo shehui fazhan diqu chaju de yanjiu (Society and Development: Study of Gaps of Social Development among Different Regions of China), Hangzhou: Zhejiang renmin chubanshe (Zhejiang People's Press), 2000. Authors' calculation based on related information.

Note: (a) Calculated in 1978 fixed prices. 
changes (urban areas are categorized in the well-off group, while rural areas are categorized in the well-to-do group), and the percentage of the povertystricken population has been cut down remarkably (far lower than the average level of developing countries). However, China is not a homogeneous country, but a heterogeneous one. We sum up the national situation in China as "one China, two systems (urban and rural)," "one China, four worlds," "one China,

Table 4.7 Regional disparities in terms of comprehensive knowledge capabilities: ranking by knowledge development indicator (KDI) (1998)

\begin{tabular}{|c|c|c|c|}
\hline & Eastern China & Central China & Western China \\
\hline $\begin{array}{l}\text { High knowledge } \\
\text { level (KDI } \geq 150 \% \text { ) }\end{array}$ & $\begin{array}{l}\text { Beijing }(606.05) \\
\text { Shanghai }(529.03) \\
\text { Tianjin }(283.70) \\
\text { Guangdong }(212.74) \\
\text { Fujian }(156.48) \\
\text { Jiangsu }(154.55)\end{array}$ & & \\
\hline $\begin{array}{l}\text { High/middle } \\
\text { knowledge level } \\
(150 \%>\text { KDI } \geq 100 \%)\end{array}$ & $\begin{array}{l}\text { Hainan (127.64) } \\
\text { Liaoning }(126.69) \\
\text { Zhejiang }(122.71)\end{array}$ & & \\
\hline $\begin{array}{l}\text { Middle/low } \\
\text { knowledge level } \\
(100 \%>\text { KDI } \geq 75 \%)\end{array}$ & $\begin{array}{l}\text { Shandong (82.05) } \\
\text { Hebei }(75.69)\end{array}$ & $\begin{array}{l}\text { Jilin }(99.53) \\
\text { Hubei }(92.18) \\
\text { Heilongjiang (84.63) }\end{array}$ & Shaanxi (88.05) \\
\hline $\begin{array}{l}\text { Low knowledge } \\
\text { level (KDI }<75 \%)\end{array}$ & & $\begin{array}{l}\text { Hunan }(69.72) \\
\text { Shanxi }(64.27) \\
\text { Henan }(63.74) \\
\text { Jiangxi (61.04) } \\
\text { Anhui (57.69) }\end{array}$ & $\begin{array}{l}\text { Xinjiang (65.85) } \\
\text { Chongqing (63.71) } \\
\text { Gansu (58.32) } \\
\text { Inner Mongolia (56.59) } \\
\text { Ningxia (54.70) } \\
\text { Sichuan (51.49) } \\
\text { Guangxi (50.88) } \\
\text { Yunnan (48.75) } \\
\text { Qinghai (44.18) } \\
\text { Guizhou (38.32) } \\
\text { Tibet (31.99) }\end{array}$ \\
\hline
\end{tabular}

Source: A. Hu and Y. Xiong, "Woguo zhishi fazhan diqu chaju yanjiu: tedian, duice he chengyin" (Analysis of Regional Disparities of China's Knowledge Development: Characteristics, Causes and Countermeasures), Guanli Shijie (Management World), 2000, Issue 3.

Notes: National KDI $=100 \%$.

Indicators used for measuring knowledge development in a certain region include three dimensions: acquiring knowledge, absorbing knowledge and exchanging knowledge. The three dimensions are measured respectively by the number of internationally employed treatises (including those covered by three retrieval tools, SCI, EI and ISTP) per every one million people, the number of approved patents per every one million people, per capita FDI; the per capita number of years on average of exposure to education, the proportion of students entering the elementary schools, the number of students on campus in middle schools per every 10,000 people, the number of students on campus in colleges and universities per every 10,000 people, and the per capita number of newspapers subscribed, telephone diffusion rate, and the number of computers possessed per every 10,000 people. The country's average level is at $100 \%$, then conduct indexation of these indicators. The knowledge capability indicators of different regions can be worked out by means of weighted averages. 
four societies (agricultural, industrial, service and knowledge society)," which is far more complicated than we can depict. This is a basic national situation to which we must pay special attention when discussing how to construct an all-round well-off society.

\section{Insights into the real problems}

\section{Breakdown of income disparities}

Since the beginning of reform and opening up, income disparities among different regions, between rural and urban areas, and even within rural areas and within urban areas, have kept enlarging. The 2004 World Bank Report analyzed in detail various factors giving rise to income disparities, and also broke down those factors using the data from 1990 to 1999 (see Figure 4.2). They point out that the main factor is the increasing income disparities between rural and urban areas in the middle and late 1990s, which reflects the institutional costs of "one country, two systems" (i.e. different institutional systems governing the urban and rural areas). The second factor is the income disparities among rural areas, which reflects the slow growth or even decline of agricultural income in the inland agricultural provinces. This decline is due to the descending prices of most agricultural products in the international and domestic markets associated with the opening of China's agricultural products market in the first half of the 1990s. The third factor is the expanding income disparities among urban areas, which is caused by the emergence of so-called transitional poverty-stricken populations associated with enormous unemployment of former employees in the state-owned and collective enterprises in the second half of the 1990s. The last factor is the expanding income disparities among provinces.

It is noteworthy that the regional disparities, to a large extent, can be explained by the regional gaps at the urbanization level. In other words, the development disparities across regions are highly correlated to the development disparities between rural and urban areas. Therefore, in the World Bank Report, the breakdown of income disparities using the Theil index consists of the income disparities between rural and urban areas first, and then the income disparities among provinces (inter-province disparities), and finally the income disparities within the same provinces (inner-province differentials). ${ }^{9}$ In fact, such a breakdown has underestimated the influence of unbalanced regional development on income disparities.

\section{Income disparities due to regional features}

In order to further explore the origins behind the variations of regional disparities in terms of per capita GDP, we may breakdown the Theil coefficient, which represents the variations of per capita GDP, into regional components, and study how these components and their discrepancies influence and contribute to the 


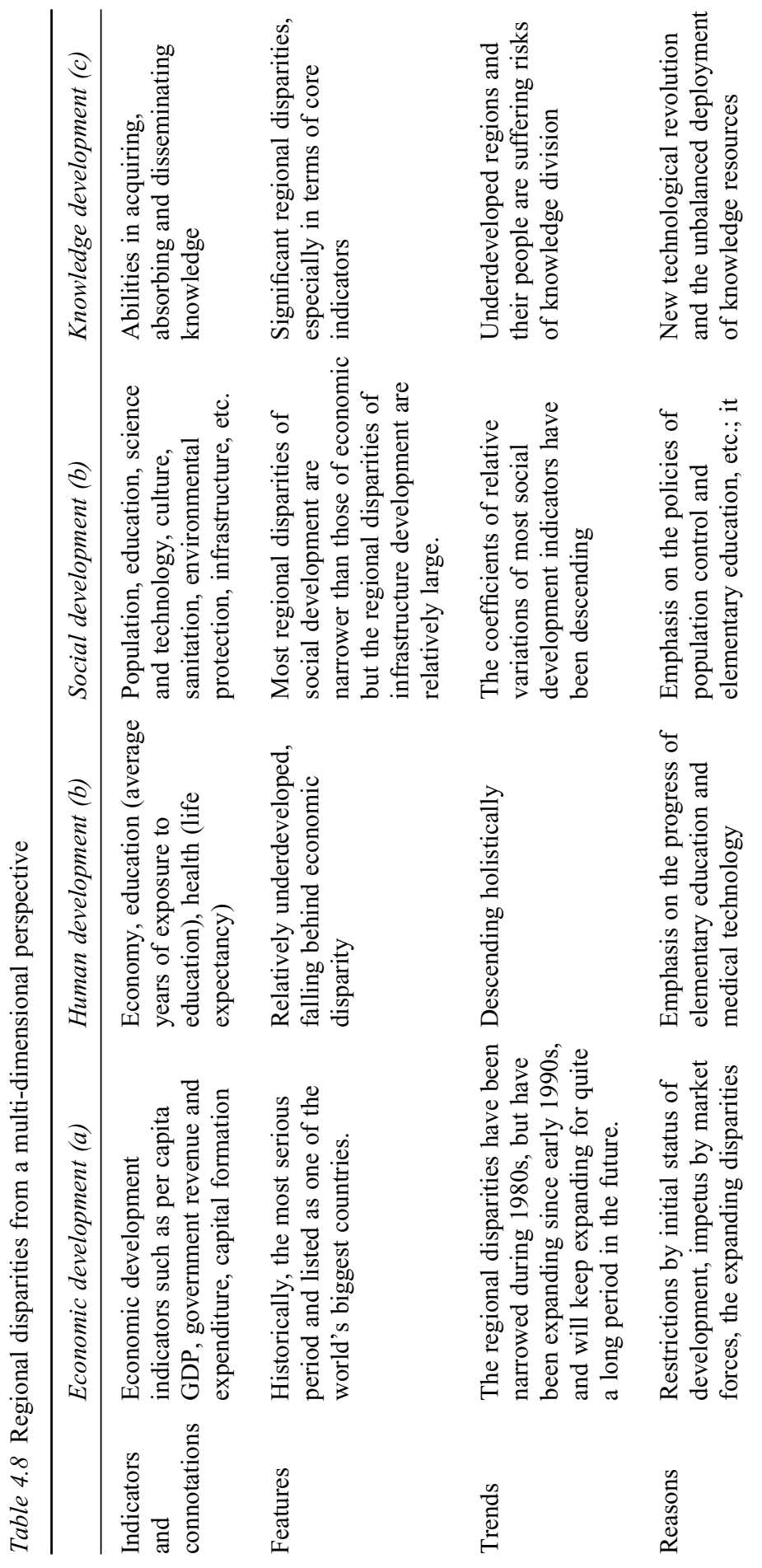




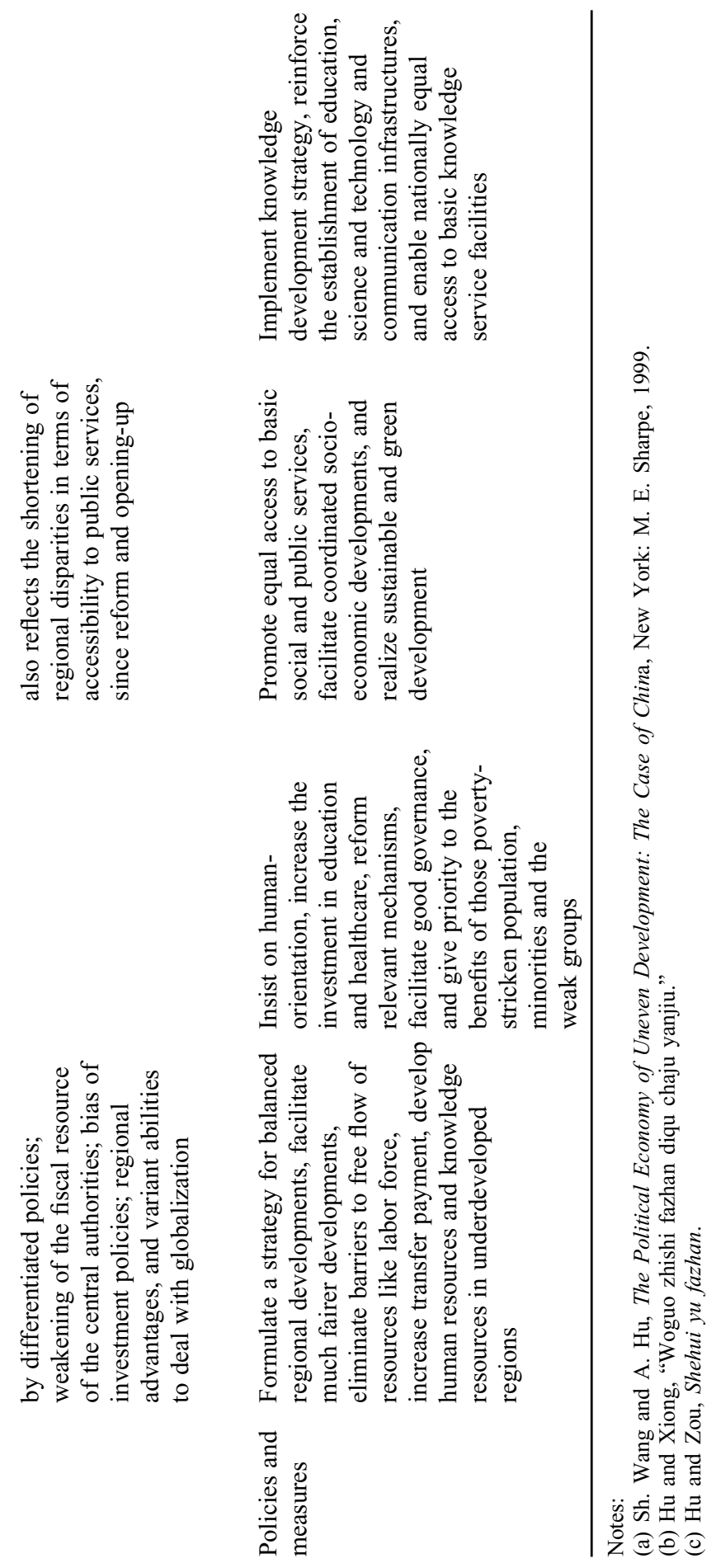




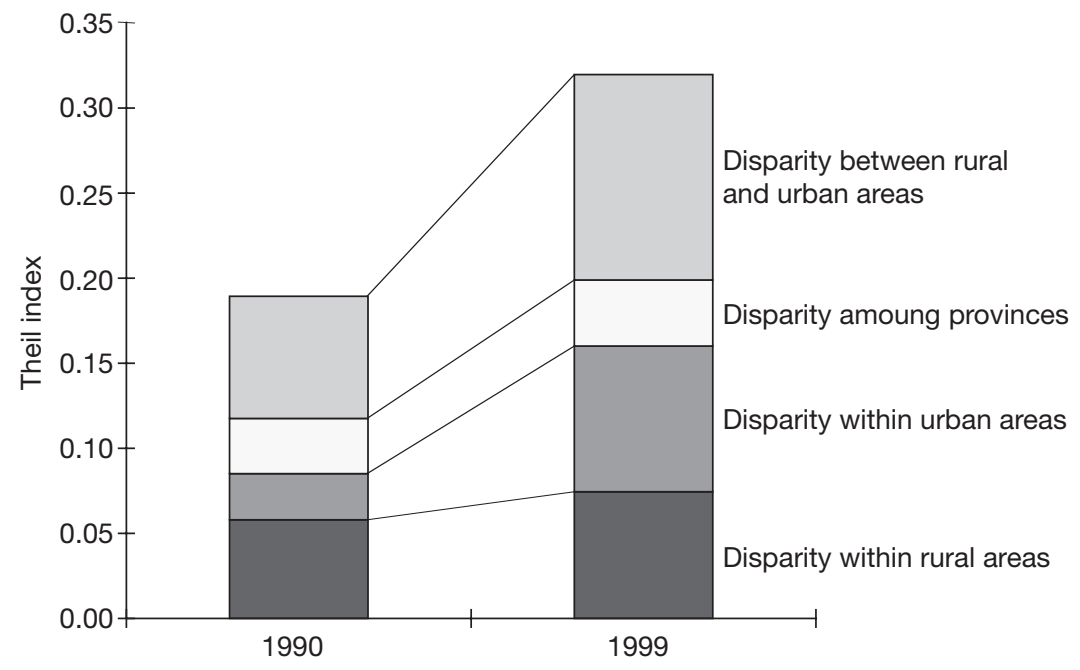

Figure 4.2 Breakdown of income disparities (1990-1999)

Source: World Bank, China: Promoting Growth with Equity (Chinese edition), Beijing: Qinghua daxue chubanshe (Tsinghua University Publishing House, 2004).

national coefficient of variations of per capita GDP. We find that the within-group variation in each of the three major regions shows a trait of "convergence," while the between-group variation among them takes on an obvious "divergence."

Since the early 1990s, the expansion of regional disparities has mainly originated from the enlargement of regional disparities among the three major areas or regions. The within-region disparities, either absolutely or relatively, have kept falling. For instance, the Theil coefficient with regard to within-region disparities declined from 0.075 in 1978 to 0.043 in 2002, and the contribution rate to regional disparities has dropped from 70.81 percent in 1978 to 31.29 percent in 2002. Specifically, the within-region disparities of eastern China have reduced at the fastest speed, which is also the principal reason for the decreasing regional disparities in 1980s. In contrast, the Theil coefficient with regard to between-region disparities climbed from 0.031 in 1978 up to 0.096 in 2002, and the contribution rate to regional disparities also surged from less than 30 percent in 1978 up to two-thirds in 2002.

Similar situations are observed in terms of human development disparity, social development disparity and knowledge development disparity. The major reason behind these phenomena is the disparities between coastal regions (in eastern China) and inland regions (in central and western China).

In Table 4.9, aside from western regions, northeastern regions also dropped down in the ranking list. This indicates that aside from the well-known "gaps between the east and the west" (or east-west gaps), the "gaps between the south and the north" (or south-north gaps) also exist in contemporary China. The 
south-north gaps mainly refer to the disparities between coastal regions in southern and eastern China and those regions in northern and northeastern China. Compared to the east-west gaps, the south-north gaps are much smaller and present different features. The development level of northeastern China is higher than the national average, while that of western China is lower than the national average. The south-north gaps are mainly due to the disparity of development speed, while the east-west gaps can be attributed also to the disparity of development level.

Statistically, the expanding gaps between the east and the west are the major factors responsible for the enlarging regional disparities, while the south-north gap of development speed has, to some degree, reduced the overall regional disparities at the national level. However, if the south-north gap of development speed keeps expanding, it will become an important source for the regional disparities in China.

\section{Evolutionary trend of regional disparities}

China is a country with a broad territory and rapid socio-economic development. It is very difficult to distribute the benefits of economic growth equally among different groups and regions. The spontaneous market forces will give rise to the continuous enlargement of development gaps, especially economic disparities. Therefore, it is highly necessary to adopt measures to prevent such trends.

Table 4.9 Ranking of all provinces: the changing trend (by per capita income, 1980-2002)

\begin{tabular}{lll}
\hline $\begin{array}{l}\text { Variations of } \\
\text { the ranking } \\
\text { results }\end{array}$ & Going up & Going down \\
\hline No.6-No.15 & Fujian (15), Henan (9) & $\begin{array}{l}\text { Tibet (13), Ningxia (12), Gansu (12), } \\
\text { Qinghai (11), Shanxi (9) }\end{array}$ \\
No.3-No.6 & $\begin{array}{l}\text { Shandong (8), Zhejiang (6), } \\
\text { Hainan (6), Chongqing (6), }\end{array}$ & $\begin{array}{l}\text { Heilongjiang (5), Liaoning (4), } \\
\text { Shaanxi (3) }\end{array}$ \\
& $\begin{array}{l}\text { Hebei (4), Inner Mongolia (4), } \\
\text { Xinjiang (4), Anhui (4) }\end{array}$ & \\
No.1-No.2 & $\begin{array}{l}\text { Hunan (2), Guangdong (2), } \\
\text { Yunnan (2) }\end{array}$ & Jilin (2), Sichuan (1) \\
Unchanged & $\begin{array}{l}\text { Beijing, Tianjin, Shanghai, } \\
\text { Jiangsu, Jiangxi, Hubei, Guangxi, }\end{array}$ & \\
& Guangxi, Guizhou
\end{tabular}

Sources: Gaige kaifang shiqinian de zhongguo diqu jingji (China Regional Economy: A Profile of 17 Years of Reform and Opening-up), Beijing: Zhongguo tongji chubanshe (China Statistics Press); Guojia tongjiju (National Bureau of Statistics of China), Zhongguo tongji nianjian 2000 (China Statistical Yearbook 2000), Zhongguo tongji chubanshe (China Statistics Press), 2000, p. 62 and p. 65 . 
The past two decades have seen the fastest expansion of income disparities. Currently, China also records the greatest increasing amplitude of the Gini coefficient in the world. In the future, China will be faced with a severe challenge of enlarging income disparities. If China ignores the disparities and unbalanced income growth between rural and urban areas, the income disparities are expected to expand dramatically. The Gini coefficient for China is estimated to reach 0.474 by 2020 , from 0.437 in 1999 . Instead, if we reverse the assumption (e.g. by eliminating the gaps in economic growth among provinces, so the growth rates of income all reach 7.2 percent in every province), the Gini coefficient will drop down to 0.395 by 2020 .

At a certain future period, the relative disparities of human development indicators and most social development indicators are likely to narrow, to different degrees. However, the economic disparities and knowledge disparities will keep enlarging for quite a long period. It will take a long time for currently disadvantageous regions to catch up with the modernization process. When considering eliminating regional disparities, it is suggested to give first priority to narrowing the disparities of social development and human development. To achieve the proposed goals is not only possible and feasible, but also helpful for realizing the final target of eliminating economic disparities. Therefore, it is necessary to take "narrow regional disparities of social development and realize the equalization of public service access" as the prioritized policy in the State's long-term plan entitled "Accelerating the development of central and western China by 2015." Such a strategy will not only accelerate economic development, but also facilitate social progress in these regions.

\section{Offering public services to 1.3 billion people}

In China, the fundamental political state is a "unitary system with 5.5 levels in governmental hierarchy." China is a unitary state, not a federal one. The Constitution of China has set down clear provisions regarding "4-levelled government." However, governance operates at 5.5 levels: Central Level, Provincial Level, Deputy Provincial Level, Regional/Municipal Level, County/City Level, and Township/Village/District Level. There are too many administrative levels of government in China. Even governments at the same level but in different regions vary from one another markedly in terms of the size of population, public affairs, public services and management capabilities. Undoubtedly, such a mechanism increases the difficulty of realizing coordinated regional development and offering people basic and easily accessible public services.

\section{Human orientation: a new philosophy of development}

It is necessary to cultivate a new philosophy of development. In the twentyfirst century, major transitions in the issues of development have already taken place in both philosophy and strategy. This round of transitions aims to improve 
the living conditions and to enhance the quality of life for humankind, while maintaining the bearing capacity of the ecological system.

The traditional philosophy of development views increasing GDP as the only purpose. As a materials-oriented philosophy, it is a strategy of "prioritizing growth" which focuses solely on pursuing GPD growth. However, development does not equal growth. It essentially refers to the transformation of the entire society, a process that facilitates the modernization of traditional relationships, traditional patterns of thinking, traditional ways of production, and traditional life-styles.

The newly formulated strategy of development is a human-oriented one, which focuses on improving living conditions and enhancing the quality of life. It aims to increase employment opportunities and to improve people's capabilities to face new challenges. To reach these goals, many measures can be adopted, such as developing human resources, protecting the diversity of ethical cultures and achieving sustainable development. The new philosophy of development is not a strategy with a single goal, but one with multiple objectives at multiple levels. It is not a strategy pursuing only economic growth, but one seeking comprehensive socio-economic development. It is not a strategy pursuing only the protection of the ecological environment, but one that intends to protect and develop ethical cultures and to facilitate human development and social transition. To be more precise, it is also a strategy that promotes the coordinated development between economic growth and social progress.

\section{Current policies}

It is an important philosophy of China's government to emphasize coordinated development between rural and urban areas, coordinated regional development and coordinated socio-economic development. On March 18, 2003, the newly appointed Chinese premier Wen Jiabao announced a new policy direction with twenty-four words (in Chinese): "Coordination between rural and urban; complementariness between east and west; communication between internal and external parties; integration between super-ordinate and subordinate; harmonization between short- and long-terms; and put into force effective and flexible policies." The "Decision upon a Certain Number of Problems with Regard to Consummation of the Socialist Market Economy System by the Central Committee of the Communist Party of China" passed at the Third Plenary Session of the Sixteenth Central Committee of the CPC put forward the requirements of "insisting on human orientation, establishing a philosophy of comprehensive, coordinated and sustainable development, and facilitating the integration of socio-economic and human developments." It also clarifies the new direction for development, featuring "five coordinations" of: 1) coordinating the development between rural and urban areas; 2) coordinating economic development in different regions, promoting the development of the western region and the revitalization of northeast China and other old industrial bases; 3) coordinating socio-economic development; 4) coordinating the development of human beings 
and the natural environment; 5) coordinating domestic development with opening up. ${ }^{10}$ This policy was put forward by the Central Government after having summed up its solid experience during reform and opening up over the past two decades. It is set up at the request of meeting new situations and new tasks, and dealing with those typical problems associated with socio-economic development in China. Therefore, it is considered the starting point as well as the final target of our reform.

We believe that the philosophy of "human-oriented development" brought forward during the Third Plenary Session of the Sixteenth Central Committee of the CPC is a totally new, scientific one. The fundamental purposes of reform are to invest in people, to facilitate the comprehensive development of all Chinese people and to achieve a common prosperity. The five strategies of coordinated development are suitable for the national conditions in China, and thus can be termed the second generation of China's development strategies.

During the thirty years from the founding of the People's Republic of China to the beginning of reform and opening up, in order to break through the economic embargo of Western countries, the Chinese government implemented a strategy of prioritizing heavy industry and a supplementary policy of coordinated regional development. The main considerations behind the strategy were national security and the previously established industrial base. During this period, most construction funds were allocated to inland areas. For example, more than 200 billion Yuan were invested in three-line regions, creating fixed assets of over 140 billion Yuan, as well as establishing 29,000 state-owned industrial enterprises. Throughout the three-line regions, the State erected an industrial system that takes national defense science and technology industry as the mainstream, bases itself on transport, coal, power, iron and steel and non-ferrous metal industries, and considers the mechanical, electronics and chemical industries as precursors. Such an industrial system that comprises a complete array of industries has boosted the industrial development in the central and western regions in China, ameliorated the industrial layout in China and reinforced the economic strength and national defense capabilities of China. The strategy and policies during this period ensured the extension of production capacity from coastal areas to inlands, and to some extent has facilitated resource exploitation of the inland regions. They helped coastal regions to find places to acquire material resources from and to sell their products to, ensured a roughly balanced development across different regions and lessened economic frictions among different regions. However, the control mode of "mandatory plans" adopted by the Chinese government reduced, to some extent, the efficiency of resources deployment and impeded the improvement of the whole national economy.

The first generation of development strategy was initially put forward by Comrade Deng Xiaoping after the Third Plenary Session of the Eleventh Central Committee of the CPC in 1978. Its theme was to speed up the development in an unbalanced way, and it advocated "differentiated prosperity" that permitted a portion of people in some regions to become rich first. The purpose of this 
reform was to release and develop productivity and to accelerate the development of coastal regions.

The second generation of development strategy insists on development in a coordinated, all-round and sustainable way. It also advocates that a "common prosperity" be developed for all regions jointly and that they all share benefits. The final target of this reform was to invest in human capital, to develop human capabilities and to implement the five major strategies of coordinated development. In fact, such strategic adjustments started in 1995 when the Fifth Plenary Session of the Fourteenth Central Committee of the CPS was held. In this session, Jiang Zemin put forward suggestions concerning how to properly deal with a number of significant relationships (i.e. the twelve major relations) in the socialist modernization process. He also brought forward a notion of "insisting on coordinated regional development, and narrowing regional disparities step by step." In June 1999, Comrade Jiang Zemin presented the strategy of "Western Development" which was formally put into force in 2001. The strategy has already embodied the thought of coordinated regional development. The Report of the Sixteenth National Congress of the CPC officially put forward the development objective of "building a well-off society in an all-round way" to benefit the whole population of the country, and also began to conceive the second generation of development strategy. Because of the outbreak of SARS and the painful lessons in handling the SARS crisis, the Chinese government has accelerated the strategic transition from the first generation to the second one.

As for the regional development policies, it is well known that China features two major regional disparities. One is the well-known "gap between the east and the west," while the other is the gap between the south and the north. To eliminate these two major regional gaps, it is necessary to employ strategic thought in a comprehensive way. Since June 1999 when the central authorities decided to implement the strategy of "Western Development," considerations have been given to how to reinvigorate the old industrial base in northeastern China. The Report of the Sixteenth National Congress of the CPC in 2002 pointed out the necessity of giving supports to the northeastern regions for speeding up their structural adjustments. Since March 1994, the central government has begun to consider how to reinvigorate the old industrial base in northeastern China. This new consideration can be viewed as the second biggest strategic decision following "Western Development" in the process of pursuing coordinated regional development.

The Chinese government has already successfully brought forward a relatively complete strategy for coordinated regional development. This strategy is suitable for China's conditions featuring great regional gaps, and also conforms to the will of the Chinese people.

\section{Policy suggestions (direction of development)}

We believe that it is possible for China to narrow the disparities between rural and urban areas and between different regions if it can insist on the second generation 
Table 4.10 Policies of regional development (1953-present)

\begin{tabular}{|c|c|c|c|}
\hline & $1953-1978(a)$ & $1978-1995(a)$ & 1995-present (b) \\
\hline $\begin{array}{l}\text { Regional } \\
\text { policy }\end{array}$ & Balanced development & Unbalanced development & Balanced development \\
\hline $\begin{array}{l}\text { Starting } \\
\text { point }\end{array}$ & $\begin{array}{l}\text { National security, } \\
\text { establishment of } \\
\text { industrial base }\end{array}$ & $\begin{array}{l}\text { Economic growth, } \\
\text { enhancement of macro- } \\
\text { economic benefits }\end{array}$ & $\begin{array}{l}\text { Coordinated } \\
\text { development and } \\
\text { common prosperity }\end{array}$ \\
\hline Principle & $\begin{array}{l}\text { Employment of } \\
\text { planning means, } \\
\text { balanced deployment } \\
\text { of resources and } \\
\text { productivity }\end{array}$ & $\begin{array}{l}\text { Prioritize the efficiency, } \\
\text { consider fairness, } \\
\text { advocate "differentiated } \\
\text { prosperity," boost } \\
\text { economic development } \\
\text { from coastal regions to } \\
\text { inland areas step by step }\end{array}$ & $\begin{array}{l}\text { "Human orientation," } \\
\text { coordinated regional } \\
\text { development; narrow } \\
\text { regional disparities }\end{array}$ \\
\hline $\begin{array}{l}\text { Concrete } \\
\text { polices }\end{array}$ & $\begin{array}{l}\text { Extension of production } \\
\text { capacity from coastal } \\
\text { regions into the inland } \\
\text { areas; ensure roughly } \\
\text { balanced regional } \\
\text { development; invest } \\
\text { mainly in inland areas, } \\
\text { and construct the three- } \\
\text { line regions. }\end{array}$ & $\begin{array}{l}\text { Establish special economic } \\
\text { zones and development } \\
\text { zones, grant favorable } \\
\text { policies to coastal regions, } \\
\text { separate financial powers, } \\
\text { reduce the investment in } \\
\text { central and western China }\end{array}$ & $\begin{array}{l}\text { Initiate Western } \\
\text { Development, build } \\
\text { a well-off society, } \\
\text { reinvigorate the old } \\
\text { industrial base in } \\
\text { northeastern China, } \\
\text { etc. }\end{array}$ \\
\hline Effects & $\begin{array}{l}\text { Facilitate resource } \\
\text { exploitation and } \\
\text { economic development } \\
\text { in inland areas, but } \\
\text { distort resource } \\
\text { allocation to some } \\
\text { extent, impede the } \\
\text { enhancement of overall } \\
\text { national economy. } \\
\text { Generally speaking, } \\
\text { regional disparities } \\
\text { expand in a fluctuant } \\
\text { way }\end{array}$ & $\begin{array}{l}\text { Intensive market forces } \\
\text { boost the optimization of } \\
\text { resources deployment } \\
\text { and the rationalization of } \\
\text { productivity layout; the } \\
\text { economies at both } \\
\text { regional level and national } \\
\text { level all grow quickly. In } \\
\text { the } 1990 \text { s, regional } \\
\text { disparities of economic } \\
\text { development expanded } \\
\text { fast; China became one } \\
\text { of those countries with } \\
\text { the largest regional } \\
\text { disparities. }\end{array}$ & $\begin{array}{l}\text { Require efforts over a } \\
\text { period of time, } \\
\text { maintain the } \\
\text { continuous economic } \\
\text { growth, and create } \\
\text { material conditions for } \\
\text { coordinated regional } \\
\text { development. Reform } \\
\text { the economic } \\
\text { mechanism and } \\
\text { governmental } \\
\text { governance, so as to } \\
\text { institutionally } \\
\text { guarantee coordinated } \\
\text { regional development. } \\
\text { Economic disparities } \\
\text { keep increasing, but at } \\
\text { a slower speed. }\end{array}$ \\
\hline
\end{tabular}

Source: (a) A. Hu, Sh. Wang and X. Kang, Zhongguo diqu chaju baogao (Report on Gaps among Different Regions of China), Shenyang: Liaoning renmin chubanshe (Liaoning People's Press), 1995.

(b) Hu and Xiong, "Woguo zhishi fazhan diqu chaju yanjiu." 
of development strategy, further quicken the establishment of a unified and fair domestic market, promote the free flow of various factors of production, especially the labor force, and accelerate the process of urbanization.

\section{Political support and commitments from the central government are of top importance}

In the transition of China from a traditional planned economy to a marketoriented one, no proven experience or mature theories from international society are available for reference. The transition process involves the redistribution of benefits and powers. Therefore, the central government plays a non-replaceable role in eliminating the regional disparities of development and boosting the speedy development of underdeveloped regions.

Solid experience from many other countries has demonstrated that the influences of external environmental factors such as globalization on economic growth, poverty and income distribution vary markedly from one country to another. The degree of such influences depends, to a large extent, on the policies adopted by the country concerned.

After rapid development over the past twenty-five years, China has already equipped itself with the necessary conditions for solving the regional disparities of development, and the central government has also been able to provide necessary support in terms of institutions, policies and funds to boost coordinated regional development. As there are various kinds of conflicting interests between central and local governments, and the process of structural and institutional reforms is rather complicated, some measures that are conformable to the interests of most Chinese people and are also beneficial for China in enhancing her competitiveness, will probably be resisted by some interest groups. Furthermore, many dilemmas need to be evaluated carefully, making it difficult for actual implementation.

Faced with heavy resistance, a very strong political determination is needed to carry out the reform and ensure the development of the macro-economy in a fast, stable and coordinated way. To implement the second generation of development strategy and facilitate coordinated regional development, powerful political supports and commitments are definitely required.

\section{Establishment of a unified, open and fair domestic market is an important measure for coordinated regional development}

The National Congress decision put forward the concept of eliminating the barriers between different regions, clarified the necessity of discarding unreasonable regulations of regional protectionism, and broke industrial monopoly and regional isolation. Only by opening markets inward and outward, speeding up the construction of a unified domestic market and facilitating the flow and development of various kinds of factors, can every region be able to gain more 
economy-of-scale effects from national and regional markets, just as the member countries in the EU gain benefits from the greater EU market. ${ }^{11}$

By investigating the development of China's labor force market, we find that the flow of the labor force across enterprises, industries and regions has promoted the adjustment of economic structures, and also facilitated decreasing gaps between rural and urban areas and between different regions. As productivity in the agricultural sector lags behind that of industry and the service sector, the transfer of the agricultural labor force into non-agricultural sectors is extremely vital to promoting economic growth and coordinated regional development in the future. Currently, a majority of productive employment opportunities are available in those regions with intensive economic activities, but not in remote rural regions. Therefore, the transfer of the agricultural labor force into nonagricultural sectors is now closely associated with the movement of the agricultural population into urban areas.

It is necessary that we clarify the responsibilities of local government with respect to local enterprises, financial institutions and courts, and make clear the responsibilities of local governments in monitoring market activities and making policies. In addition, it is necessary to take some innovative measures so as to ensure the accountability of local governments for their market interventions. Such measures may include a market survey to investigate the management practices of local government. Moreover, China should complete its legal system corresponding to its commitments to WTO.

It is advised that further systematic reform be implemented to facilitate the movement of the labor force, and to further release the restrictions upon population movement. In fact, such measures were already taken in 2001. If social security funds and related services are concentrated at the provincial level, and the coverage of the social security system is expanded to include non-stateowned sectors in urban areas (i.e. inclusive of both local residents and migrant workers), this will undoubtedly facilitate the free flow of the labor force across and within urban regions. It is essential to continue reforming the regulations on land use, so as to enable farmers to receive adequate compensation by subleasing or transferring their lands through lawful ways. Such reforms will be helpful for the movement of the population from rural areas into urban ones. One more measure, which may be beneficial for increasing the overall liquidity of the labor force market, is to develop the urban land market and to promote housing development for the low-income population living in urban and suburban areas.

\section{Urbanization: a good remedy for narrowing the disparities between urban and rural areas and between different regions}

The concentration of population and resources will promote economies of scale and will improve economic efficiency. Due to the economic advantages resulting from industry clustering, the newly added outputs and productive employ- 
ment opportunities in both service sectors and the manufacturing industry may emerge principally in urban and suburban areas. Since the beginning of reform and opening up, a majority of employment opportunities in non-agricultural sectors have been created by small and medium sized cities. Specifically, the suburban areas have witnessed the largest number of newly added employment opportunities.

It is necessary to set up a complete market system for the development of land used for industrial purposes, so as to facilitate the development of housing for low-income populations. Such a measure will further demonstrate the advantages of integrated development in China. If strict supervision and powerful policy support from government are both available, commercial interests will drive the development and utilization of land towards the expected mode.

The holistic effects of urbanization also depend on measures taken by the government to boost the development of suburban regions and to improve the quality of life in urban areas. When moving out from central urban areas, industrial enterprises may prefer suburban regions, as these regions are advantageous for both initiating business activities and housing development. In this respect, local governments may have to play a more active role in the market of suburban lands for housing purposes, so as to boost the development of housing for low-income populations. International experience has proven that the roles of government should include providing basic social infrastructures and public services in those regions close to economic activities, or in those regions suitable for low-income populations to live in. As a matter of fact, public services are increasingly important in establishing a self-contained central area that not only hosts economic activities, but also promotes a high quality of life. Such public services may include an appropriate public transit network, basic educational facilities for local residents, sound environmental protection, and so on.

\section{Allow equal access to basic public services at a national level}

In order to eliminate the remarkable regional disparities of socio-economic development, it is necessary to enable national citizens to equally obtain access to basic public services. To reach this goal, it is necessary to formulate the national minimum standards of basic public services.

It is necessary to set up a system for standardizing transfer payments from the treasury. For central and western regions, the transfer payment should be increased so as to balance the per capita financial capability across all regions. In China, the current intra-government fiscal system cannot ensure the sufficiency of public services. Despite a relatively big amount of inter-government transfer payments (in 2001 and 2002, the amount of central government's transfer payments constituted 46 percent and 48 percent of the financial expenditure of local governments respectively), the unreasonable transfer system makes local government unable to provide funds for some important social services, such as education and public health care in rural areas. The central government has 
shifted the responsibility of financial expenditure to local governments, but not provided adequate financial supports at the same time. Such incompatibility will worsen the imbalance of financial operations, and further expand the income disparities among different regions. Obviously, this conflicts with what the governments should be doing (such as alleviating the income disparities, protecting the poverty-stricken population and the weak groups). To make things worse, the governments in poverty-stricken regions are providing fewer public services with lower quality, and shifting a relatively high proportion of the costs to local people.

It is essential to clarify the expenditure purposes of transfer payments from the exchequer. We find that, in 1998, among the eight provinces/autonomous regions where minorities occupy a relatively higher proportion, seven provinces/ autonomous regions except Guizhou province all reported a per capita financial expenditure level higher than the national average. However, their major social development indicators and human development indicators have all turned out lower than the national level. Among these regions, a majority of funds were spent to support institutions and their employees, whereas only a small portion was invested in public services. As a result, it is necessary to shift from unconditional transfer payments to conditional ones. The central government should provide funds in such a way as to force local governments to effect reforms, so as to enhance the effectiveness and efficiency of financial transfer payments for offering public services. In addition, the centralization of public service responsibilities and fund management authorities will facilitate the provision of better services. For example, the shift of some responsibilities concerning service provision and fund-raising from governments at village, town or county levels to their super-ordinate governments can enhance efficiency, management abilities and fairness. The reform of the financial revenue and expenditure system should make the financial and institutional capabilities of governments compatible with their corresponding responsibilities.

Coordinated regional development requires the clarification of responsibilities between the central government and provincial governments, and the implementation of a combined mode of "centralization of central government and decentralization of local governments." Further, it is necessary to make clear the respective responsibilities of the central government and the local governments in respect to economic adjustment, market supervision, social management and public services. Those affairs at national or intra-provincial levels should be coordinated by the central authority, so as to guarantee a unified legal system, governmental decrees and national markets. Those affairs within local administrative regions should then be managed by local governments, so as to improve working efficiency, reduce managerial costs and enhance administrative capability. As to those affairs jointly managed by the central authority and local governments, it is necessary to identify their respective roles, and to clarify the primary and secondary responsibilities as well. 


\section{Developing human resources: a prioritized strategy for narrowing regional disparities of development}

Human capital constitutes the most important component of national wealth. China has the largest population in the world, and possesses the richest human resources. However, China badly lacks physical resources, capital resources and technical resources in comparative terms. The conflict between abundant labor resources and relatively scarce natural resources and capital resources has become the primary contradiction in modern China. Therefore, developing human resources is the basic national policy for China to pursue long-term development. The scarcer natural resources are, the more important it is to develop human resources. The more deficient capital is, the more necessary it is to invest in human capital. The less developed the economy is, the more essential it is to develop education, science and technology.

In China, the fundamental national policies should focus on education and science. This is the only choice for China. The basic means of developing human resources include investing more in human capital, speeding up the development of various categories of education, promoting scientific and technological advancement, ensuring the health of every citizen and eliminating absolute poverty. The core is to develop, invest in and utilize the labor resources in underdeveloped regions, so as to increase the national wealth, promote coordinated socio-economic development, and narrow regional disparities of development.

\section{Implementing the knowledge development strategy}

The domestic and international experience have indicated that knowledge is the most important factor in facilitating development. In the twenty-first century, knowledge will be the most important resource in the economic development of a country or a region. A low level of knowledge development will be the biggest bottleneck that impedes the economic development of a country or a region. Knowledge-facilitated development and knowledge-oriented society will be the themes of human development in the twenty-first century. The level of knowledge development in regions with relatively lower socio-economic development falls far below that in the developed coastal regions. The disparities of key knowledge capability will become much bigger. Thus, it is necessary to prioritize the implementation of the knowledge development strategy in underdeveloped western regions, to enhance the people's abilities to acquire, absorb and exchange knowledge, and to improve their abilities in gaining knowledge assets and information knowledge.

Corresponding to the phenomena of "one China, four scenarios," and "one China, four societies," the implementation of knowledge development strategy in China should follow three steps:

1 To allow equal access to basic knowledge services. This is the foundation for Chinese people to participate in knowledge creation and sharing. 


\section{Economic and social transformation in China}

2 To accelerate the application of knowledge nationally. In contemporary China, the scientific level and technological innovations still remain on a rather low level from an international perspective, which means that acquiring and absorbing foreign knowledge should be the primary consideration for accumulating a knowledge base. Therefore, all regions in China should improve their abilities in utilizing global knowledge as quickly as possible, complete their networks for dissemination and application of knowledge, and promote more intensive utilization of knowledge in socio-economic development.

3 To strengthen the capabilities of knowledge innovation step by step. The first two measures aim at improving "basic knowledge capabilities." On the basis of these basic knowledge capabilities, China should cultivate its capabilities in knowledge innovation gradually, formulate an effective stimulating mechanism, set up an interactive innovation system and utilize limited resources to develop new knowledge. Among these, allowing equal access to basic knowledge services nationwide serves as the foundation for implementing the knowledge development strategy, and thus should be treated as a high-priority strategy. 


\section{China's economic growth and poverty reduction (1978-2002) $)^{1}$}

\section{The trend and evaluation of China's poverty reduction (1978-2002)}

\section{Great achievements in poverty reduction}

Since China's economy entered the takeoff stage in 1978, the average growth rate of per capita GDP has been as high as 8.1 percent. As Amartya Sen has analyzed, in the past two decades China's economy has been developing very rapidly. The growth of China's income per capita is much faster than that of any other region in the world. Nevertheless, people have always failed to realize that this is rather astounding for such a large country as China. It's totally different from those well-known countries or regions with rapid economic growth such as Hong Kong and Singapore. Unlike China, which has a very large rural population, Hong Kong and Singapore are actually cities. It is an extraordinary achievement for such a large country with dramatic regional differences to achieve such a high average growth rate. ${ }^{2}$ Meanwhile, China's rural impoverished population has decreased by a large margin. According to China's national poverty line, the rural impoverished population has dropped from 250 million in 1978 to 28.2 million in 2002, decreasing by 88.7 percent. The impoverished population has decreased by an average of 9.24 million per year (see Table 5.1). According to the international poverty line, at which the cost of living per capita per day is below $\$ 1$, the World Bank estimates that China's rural impoverished population has dropped from 280 million in 1990 to 124 million in 1997, decreasing by 55.7 percent. The impoverished population has decreased by an average of 22.29 million per year (see Table 5.2). These different estimates demonstrate that while China is the country with the largest population and the largest impoverished population, it has made unprecedented achievements in poverty reduction.

China's achievements in poverty reduction constitute a huge contribution to poverty reduction throughout the world. It is estimated by the World Bank that according to the international poverty line (per capita cost of living below $\$ 1$ per day), China's impoverished population dropped from 542 million to 375 million in the 1980s (referring to the period from 1980 to 1990), decreasing by 
Table 5.1 Annual rural poverty reduction, the growth rate of per capita GDP and farmers' consumption level (1978-2002)

\begin{tabular}{lllll}
\hline Year & $\begin{array}{l}\text { Annual poverty } \\
\text { reduction } \\
\text { announced by } \\
\text { the government } \\
\text { (million) (a) }\end{array}$ & $\begin{array}{l}\text { The growth rate } \\
\text { of per capita } \\
\text { GDP (\%) }(b)\end{array}$ & $\begin{array}{l}\text { The growth rate } \\
\text { of farmers } \\
\text { consumption } \\
\text { level (\%) }(c)\end{array}$ & $\begin{array}{l}\text { The growth rate } \\
\text { of farmers' net } \\
\text { income per capita } \\
(\%)(c)\end{array}$ \\
\hline $1978-1985$ & 17.86 & 8.3 & 10.0 & 15.1 \\
$1985-1990$ & 8.00 & 6.2 & 2.5 & 3.0 \\
$1990-1997$ & 5.00 & 9.9 & 8.0 & 5.0 \\
$1997-2002$ & 4.36 & 7.7 & 3.4 & 3.8 \\
$1978-2002$ & 9.24 & 8.1 & 5.6 & 7.2 \\
\hline
\end{tabular}

Sources: Guojia tongjiju (National Bureau of Statistics of China), Zhongtuo tongji zhaiyao 2002 (China Statistical Abstract 2002), Beijing: Zhongguo tongji chubanshe (China Statistics Press), pp. 18, 32 and 91. Data for 2002 are from Guojia tongjiju (National Bureau of Statistics of China), "Zhongguo 2002 guomin jingji he shehui fazhan tongji gongbao" (The Communiqué of China's National Economy and Social Development 2002), Economy Daily, March 1, 2003.

Notes: (a) Calculated according to the data of Table 5.2; (b) and (c): all calculation in fixed prices.

Table 5.2 The impoverished population in rural China and the rate of poverty (1978-2002)

\begin{tabular}{|c|c|c|c|c|c|}
\hline Year & $\begin{array}{l}\text { Rural } \\
\text { population } \\
\text { (ten thousand } \\
\text { persons) (a) }\end{array}$ & $\begin{array}{l}\text { Official } \\
\text { impoverished } \\
\text { population } \\
\text { (ten thousand } \\
\text { persons) (b) }\end{array}$ & $\begin{array}{l}\text { Impoverished } \\
\text { population } \\
\text { estimated by } \\
\text { the World Bank } \\
\text { (ten thousand } \\
\text { persons) (d) }\end{array}$ & $\begin{array}{l}\text { The rate of } \\
\text { poverty (\%), } \\
\text { Official data } \\
\text { (c) }\end{array}$ & $\begin{array}{l}\text { The rate of } \\
\text { poverty (\%), } \\
\text { World Bank } \\
\text { data }\end{array}$ \\
\hline 1978 & 79014 & 25000 & & 33.1 & \\
\hline 1984 & 80340 & 12800 & & 15.9 & \\
\hline 1985 & 80757 & 12500 & & 15.5 & \\
\hline 1986 & 81141 & 13100 & & 16.1 & \\
\hline 1987 & 81626 & 12200 & & 14.9 & \\
\hline 1988 & 82365 & 9600 & & 11.7 & \\
\hline 1989 & 83164 & 10600 & & 12.7 & \\
\hline 1990 & 84142 & 8500 & 28000 & 10.1 & 33.3 \\
\hline 1991 & 85280 & 9400 & 28700 & 11.0 & 33.6 \\
\hline 1992 & 84799 & 8000 & 27400 & 9.4 & 32.3 \\
\hline 1993 & 85166 & 8000 & 26600 & 9.3 & 31.2 \\
\hline 1994 & 85549 & 7000 & 23700 & 8.2 & 27.7 \\
\hline 1995 & 85947 & 6500 & 20000 & 7.6 & 23.3 \\
\hline 1996 & 86439 & 6000 & 13800 & 6.9 & 16.0 \\
\hline 1997 & 86637 & 5000 & 12400 & 5.8 & 14.3 \\
\hline 1998 & 86868 & 4200 & & 4.8 & \\
\hline 1999 & 87012 & 3412 & & 3.7 & \\
\hline 2000 & 80837 & 2200 & & & \\
\hline 2001 & 79563 & $2713 c$ & & & \\
\hline 2002 & & $2820 \mathrm{c}$ & & & \\
\hline
\end{tabular}

Sources: (a) Guojia tongjiju, Zhongguo tongji zhaiyao 2002; (b) “A Monitoring Report of China's Rural Poverty in 2000" by the research office of rural social economy of national statistics bureau, China's Statistical Press, 2000, p. 7; (c) "Statistical Communiqué of China's Economy and Society" by National Statistical Bureau, quoted from Economic Daily, March 1, 2003; (d) World Bank, 1999. 
167 million. In the corresponding period, the impoverished population of the whole world decreased by 98.3 million. China's contribution rate to the world's (mainly referring to the developing area) poverty reduction is 166.9 percent. In the 1990s, China's impoverished population decreased by 115 million, and the contributing rate was 122.8 percent. It is also estimated by the World Bank that China's impoverished population will drop to 74 million; the net decrease will be 150 million, compared with that in 1999, which will account for 41.7 percent of the whole world's (mainly referring to the developing area) poverty reduction. In 1990, China's impoverished population accounted for 29 percent of that of the world; the number has been down to 19.2 percent in 1999, decreasing by approximately 10 percent. It is forecast that the number will be down to 9.1 percent in 2015 (see Table 5.3).

Asia has the largest and most condensed impoverished population. Among the five Asian countries with the most condensed impoverished populations (China, India, Pakistan, Indonesia and Bangladesh), according to the international poverty line, China's current proportion of impoverished population is the lowest. The ratio between China's per capita GDP (PPP) and India's per capita GDP is 1.6:1; and India's ratio of people whose cost of living per day is less than $\$ 1$ is 25.7 percent higher than that of China, while India's ratio of people whose cost of living per day is less than \$2 is 32.5 percent higher than that of China (see Table 5.4).

The preceding statistics demonstrate that China has experienced a period in human history in which the impoverished population decreased by the largest margin in the past two decades, and reversed the trend that the impoverished population has been increasing in the past five decades of world history, causing the impoverished population of the world to decrease for the first time (see Table 5.5). That is to say, without China's efforts at poverty reduction, or excluding China's impoverished population, the impoverished population of the

Table 5.3 Number of people living on less than \$1 per day, estimated by World Bank (1990-2015) (million)

\begin{tabular}{lrrrrrr}
\hline Region & 1990 & \multicolumn{3}{c}{1999} & \multicolumn{3}{c}{2015} \\
\hline East Asia and the Pacific & 486 & $(37.6 \%)$ & 279 & $(23.9 \%)$ & 80 & $(9.9 \%)$ \\
$\quad$ Excluding China & 110 & $(8.5 \%)$ & 57 & $(4.9 \%)$ & 7 & $(0.9 \%)$ \\
Europe and middle Asia & 6 & $(0.5 \%)$ & 24 & $(2.1 \%)$ & 7 & $(0.9 \%)$ \\
Middle East and North Africa & 48 & $(3.7 \%)$ & 57 & $(4.9 \%)$ & 47 & $(5.8 \%)$ \\
Latin America and Caribbean region & 5 & $(0.4 \%)$ & 6 & $(0.5 \%)$ & 8 & $(1.0 \%)$ \\
South Asia & 506 & $(39.2 \%)$ & 488 & $(41.7 \%)$ & 264 & $(32.6 \%)$ \\
Sub-Sahara Africa & 241 & $(18.7 \%)$ & 315 & $(26.9 \%)$ & 404 & $(49.9 \%)$ \\
Total & $1292(100.0 \%)$ & 1169 & $(100.0 \%)$ & 809 & $(100.0 \%)$ \\
$\quad$ Excluding China & 917 & $(71.0 \%)$ & 945 & $(80.8 \%)$ & 635 & $(90.9 \%)$ \\
China & 375 & $(29.0 \%)$ & 224 & $(19.2 \%)$ & 74 & $(9.1 \%)$ \\
\hline
\end{tabular}

Source: World Bank, Global Economic Prospects and the Development Countries, Washington, DC: World Bank, 2003, Table 1.9.

Note: The data in brackets are the ratio of impoverished population as a percentage of the world total population. 
Table 5.4 Percentage of the impoverished population in several Asian countries

\begin{tabular}{llllll}
\hline & $\begin{array}{l}\text { GDP per } \\
\text { capita } \\
\text { (PPP\$) }\end{array}$ & $\begin{array}{l}\text { Population below national } \\
\text { poverty line (\%) }\end{array}$ & $\begin{array}{l}\text { Population's } \\
\text { expenditure } \\
\text { below \$1 per } \\
\text { day } \% \text { Population's }\end{array}$ & $\begin{array}{l}\text { Pelowditure } \\
\text { expen } \\
\text { per day (\%) }\end{array}$ \\
\hline Bangladesh & $1,423(1998)$ & 42.7 & 35.6 & $29.1(1996)$ & $77.8(1996)$ \\
China & $3,356(1998)$ & $6.0(1996)$ & $4.6(1998)$ & $18.5(1998)$ & $53.7(1998)$ \\
India & $2,101(1998)$ & $40.9(1992)$ & $35.0(1994)$ & $44.2(1997)$ & $86.2(1997)$ \\
Indonesia & $2,806(1998)$ & $15.7(1996)$ & $27.1(1999)$ & $7.7(1999)$ & $55.3(1999)$ \\
Pakistan & $1,794(1998)$ & $34.0(1991)$ & & $31.0(1996)$ & $84.7(1996)$ \\
\hline
\end{tabular}

Source: World Bank, World Development Indicators 2001, Washington, DC: World Bank, 2001, p. 64.

Note: Numbers in brackets are the years when the researches were carried out.

Table 5.5 Impoverished population and the poverty rate of the world (1950-1999)

\begin{tabular}{|c|c|c|c|c|c|c|}
\hline & 1950 & 1960 & 1970 & 1980 & 1992 & 1999 \\
\hline $\begin{array}{l}\text { The Impoverished } \\
\text { population (million) (a) }\end{array}$ & 1805.6 & 1946.5 & 2200.7 & 2426.6 & 2800 & 2320 \\
\hline $\begin{array}{l}\text { Population in dire } \\
\text { poverty (million) (b) }\end{array}$ & 1376.2 & 1330.1 & 1304.7 & 1390.3 & 1294 & 1169 \\
\hline Poverty rate $(\%)$ & 71.9 & 64.3 & 60.1 & 55.0 & 51.3 & 38.1 \\
\hline Dire poverty rate $(\%)$ & 54.8 & 44.0 & 35.6 & 31.5 & 23.7 & 13.3 \\
\hline
\end{tabular}

Source: The data for 1950-1992 are quoted from F. Bourguignom and C. Morrisso, "Inequality among World Citizens: 1820-1992," American Economic Review, September 2002, pp. 727-744; the data for 1999 are quoted from World Bank, Global Economic Prospects, Table 1.9.

Notes: (a) refers to people living under $\$ 2$ per day; (b) refers to people whose cost of living per day is less than $\$ 1$.

world would have increased from 848 million in 1980 to 917 million in 1990, and then to 945 million in 1999.

\section{Why can China decrease its impoverished population by a large margin?}

The main reasons are as follows.

Continuous high economic growth is the basis of poverty reduction. The average per capita growth rate of GDP of China was 8.1 percent in the period 1978-2002 (see Table 5.1), which is the longest-lasting period with the highest growth rate of GDP per capita and the largest population who benefit from it. This corresponds to doubling per capita GDP every 8.6 years, 5.4 times the global GDP per capita growth rate in the same period (1.5 percent). According to the estimate made by the World Bank, it took Britain 58 years to double its per capita income (1780-1838), America 47 years (1839-1886), Japan 34 years 
(1885-1919), South Korea 11 years (1966-1977). In China, the annual growth rate of the rural population's consumption level (the majority of China's population) is 5.6 percent; the annual growth rate of per capita net income of farmers is 7.2 percent, corresponding to doubling their per capita income every 9.7 years (see Table 5.1), which is the major reason leading to China's great poverty reduction in the rural areas. In 1978 nearly 100 percent of peasant households had per capita net incomes below 500 Yuan. In 1985, the percentage was 77.7 percent; in 1990 it was 35 percent; and in 2001 it was only 2.5 percent. In 1985 the percentage of peasant households whose per capita net income was less than 1000 Yuan was 97.69 percent, while in 2001 the ratio was down to only 13.22 percent (see Table 5.6), which shows that the extremely poor and poor households have been sharply decreased.

A great deal of rural labor force transfers to non-agricultural industries. More and more people are employed in village and township enterprises. The number has increased from 28.27 million in 1978 to 130.86 million in 2001, accounting for 26.7 percent of the total rural work force, compared with the original ratio of 9.2 percent. In addition, in 2001, 38.16 million people worked in private rural enterprises or were self-employed, accounting for 7.7 percent of total rural employees. The total of the above two ratios is 34.4 percent, exceeding onethird of total rural employed population (see Figure 5.1).

Urbanization has been speeding up. China has experienced the largest population transition in the world since the policy of reform and opening up was carried out. This includes population transference, referring to moving from the place where one originally lives. In China's case, it refers to transferring one's household register or transforming from an agricultural population to a nonagricultural population, directly recruiting personnel for employment from rural areas, such as graduates of junior college, technical secondary school, demobilized servicemen, professional personnel and so on. Population flow refers to those whose living place remains the same, but the person himself (or herself) leaves the living place and move across a given administrative region, and

Table 5.6 Percentage of rural households grouped by per capita annual net income $(1978-2001)(\%)$

\begin{tabular}{lcccrc}
\hline $\begin{array}{l}\text { Grouping by per capita } \\
\text { net income }\end{array}$ & 1978 & 1985 & 1990 & 1995 & 2001 \\
\hline 100 Yuan and below & 33.3 & 1.0 & 0.3 & 0.21 & \\
100-300 Yuan & 64.3 & 36.9 & 8.34 & 1.06 & 2.51 \\
300-500 Yuan & 2.4 & 39.8 & 26.41 & 3.77 & \\
Over 500 Yuan & & 22.3 & 64.95 & 94.96 & 97.49 \\
Over 1000 Yuan & & 2.31 & 22.78 & 69.77 & 86.78 \\
\hline
\end{tabular}

Sources: The data for 1978 and 1985 are quoted from Guojia tongjiju (National Bureau of Statistics of China), Zhongguo shehui tongji ziliao 1990 (China's Social Statistics 1990), Beijing: Zhongguo tongji chubanshe (China Statistics Press), 1990, p. 68; the data for 1990 and 1995 are quoted from Guojia tongjiju (National Bureau of Statistics of China), Zhongtuo tongji nianjian 2000; the data for 2001 are quoted from Guojia tongjiju, Zhongtu tongji zhaiyao 2002, p. 99. 


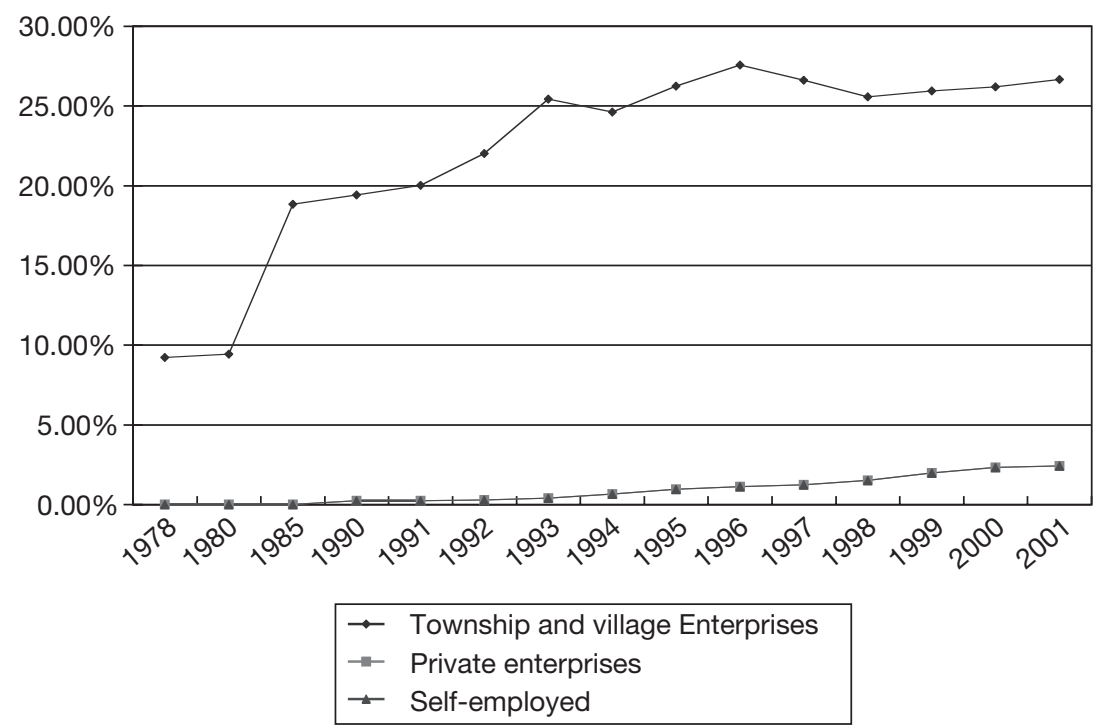

Figure 5.1 Percentage of employed persons in township and village enterprises, private enterprises and self-employed individuals in rural areas (1978-2001)

Source: Guojia tongjiju, Zhongguo tongji nianjian 2002, p. 121.

temporarily stays there and engages in various activities. The activity of rural laborers going to cities for work comes under this type of population flow. In the period 1982-2000, 206,750,000 people moved from rural to urban areas, equal to 45.0 percent of the total urban population in the same period, and 84.6 percent of the newly increased rural population (see Table 5.7). In the same period, 109,600,000 rural laborers moved to cities, equal to 45.8 percent of the total town labor force and 94.3 percent of the newly increased town labor force. From this, we can see that the scale of the moving population and labor force is enlarging rapidly. In the 1980 s, the moving population was $8,140,000$ and the moving labor force was $4,010,000$, while in the 1990 s, the numbers were $14,140,000$ and 7,750,000 respectively. Some were the agricultural population who transformed into the non-agricultural population, while the majority were rural laborers who went to cities for work. The wage income has become one of the most important sources of farmers' income. The ratio of wage income accounting for their total income was up to 30.4 percent in 2001, from 13.2 percent in 1985 (see Figure 5.2), which shows that peasants have partly enjoyed the benefits brought by urbanization and non-agricultural industries.

China's export volume has increased rapidly since implementing the policy of reform and opening up, especially since the export of labor-intensive products has increased very rapidly, which plays an important role in expanding employment and poverty reduction. The export volume of 2002 was 325.6 
Table 5.7 Population and rural-urban labor force migration (1982-2000) million

\begin{tabular}{lcllll}
\hline Period & $\begin{array}{l}\text { The increased } \\
\text { number of } \\
\text { urban total } \\
\text { population }\end{array}$ & $\begin{array}{l}\text { Total } \\
\text { migrating } \\
\text { population }\end{array}$ & $\begin{array}{l}\text { Labor force } \\
\text { migration }\end{array}$ & $\begin{array}{l}\text { Average } \\
\text { annual } \\
\text { migration } \\
\text { population }\end{array}$ & $\begin{array}{l}\text { Average } \\
\text { annual } \\
\text { laborforce } \\
\text { migration }\end{array}$ \\
\hline $1982-1990$ & 87.15 & 65.10 & 32.08 & 8.14 & 4.01 \\
$1990-1995$ & 49.79 & 39.01 & 20.20 & 7.80 & 4.04 \\
$1996-2000$ & 107.32 & 102.37 & 57.32 & 20.30 & 11.46 \\
$1990-2000$ & 157.11 & 141.38 & 77.52 & 14.14 & 7.75 \\
$1982-2000$ & 244.26 & 206.75 & 109.60 & 11.49 & 6.09 \\
\hline
\end{tabular}

Sources: Industry and Policy Department of Ministry of Agriculture. Quoted from Caijing Magazine, 2003, 3rd/4th issue, p. 95; the data of total urban population are from Guojia tongjiju, Zhongtuo tongji zhaiyao 2002, p. 34.

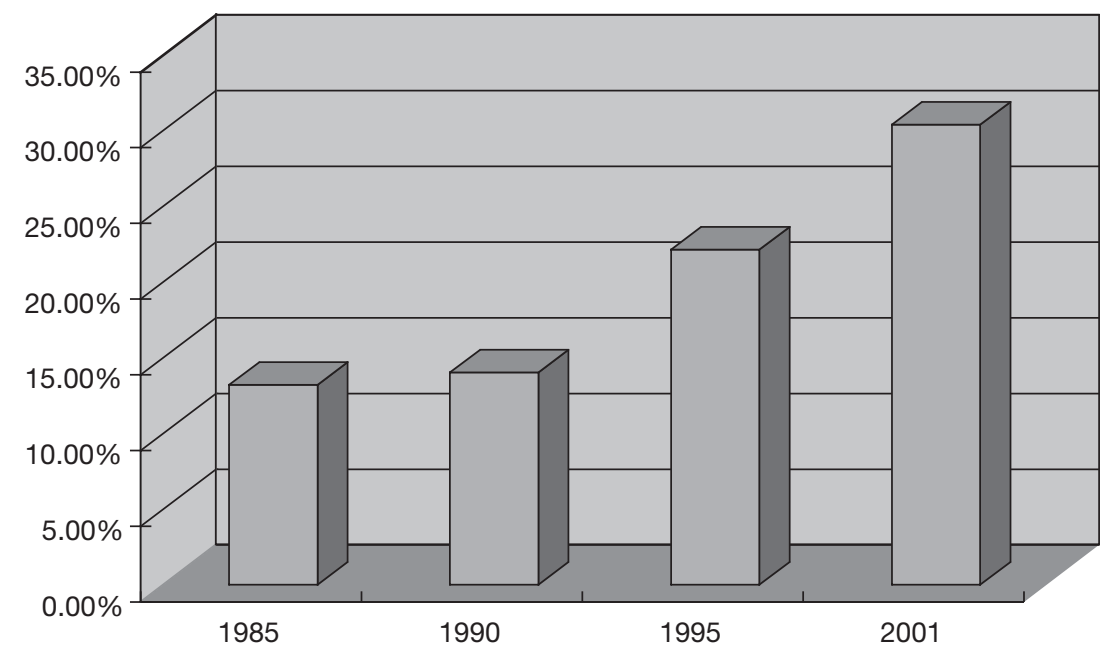

Figure 5.2 Percentage of wages income to total revenue (1985-2001)

Source: Guojia tongjiju, Zhongguo tongji zhaiyao 2002, p. 97.

billion dollars, increasing by thirty-two times that of 1978. The proportion of export volume accounting for GDP has increased rapidly from 4.6 percent in 1978 to 23.0 percent in 2001. In addition, China actively draws in foreign investment and takes an active part in economic globalization, which is also a way to achieve poverty reduction, especially since the foreign economy in Guangdong and Zhejiang attracts large quantities of surplus agricultural labor from different areas. The flowing labor force of Guangdong accounts for 39 percent of that of the whole country.

Human capital has evidently been improved. The level of people's education and health conditions have greatly improved since reform, which is useful 
Table 5.8 Basic status of China's human capital (1982-2003)

\begin{tabular}{|c|c|c|c|c|c|}
\hline & 1982 & 1990 & 1995 & 2000 & 2003 \\
\hline Average educational years & 4.61 & 5.50 & 6.09 & 7.07 & 7.36 \\
\hline $\begin{array}{l}\text { The percentage of illiterate } \\
\text { people in total population }(\%)\end{array}$ & 22.8 & 15.9 & 12.0 & 6.7 & 8.7 \\
\hline $\begin{array}{l}\text { The percentage of illiterate } \\
\text { and semiliterate rural people } \\
\text { in total population }(\%)\end{array}$ & $\begin{array}{l}27.87 \\
(1985)\end{array}$ & 20.73 & 13.47 & $\begin{array}{l}8.96 \\
(1999)\end{array}$ & \\
\hline Infant mortality rate $(\%)$ & $\begin{array}{l}37.61 \\
(1981)\end{array}$ & 32.89 & $\begin{array}{l}33.03 \\
(1996)\end{array}$ & 28.38 & \\
\hline $\begin{array}{l}\text { Average life expectancy } \\
\text { (years) }\end{array}$ & $\begin{array}{l}67.77 \\
(1981)\end{array}$ & 68.55 & $\begin{array}{l}70.80 \\
(1996)\end{array}$ & 71.40 & \\
\hline
\end{tabular}

Sources: Guojia tongjiju (National Bureau of Statistics of China), Zhongtuo tongi zhaiyao 2004 (China Statistical Abstract 2004), Beijing: Zhongtuo tongi chubanshe (China Statistics Press), 2004, p. 37.

to human capital accumulation and plays an important role in improving people's living standards and reducing poverty. As shown in Table 5.8, average educational years of people above 15 years old has increased to 7.11 years in 2000 from 4.64 years in 1982. The illiterate population has decreased greatly, the ratio of which has decreased from 22.8 percent in 1982 to 6.7 percent in 2002. The absolutely illiterate population has decreased to $84,920,000$ from $231,770,000$, of which the rural illiterate and semiliterate population has obviously decreased. The infant mortality rate has decreased from 37.61 percent in 1982 to 28.38 percent in 2000 . The average life expectancy has increased to 71.40 years in 2000 from 67.77 years in 1981. These figures demonstrate important progress in the areas of education and medical care, and the complementary relationship between economic and social progress. ${ }^{3}$

Anti-poverty actions have been adopted by the government. China's government made a political commitment to reducing poverty in the early 1980s and reflected poverty reduction goals and plans in the national economic plans. With the development of the economy, the central government's willingness to aid the poor became stronger and stronger, with the input of aid also increasing (see Table 5.9). In order to protect the benefits to the farmers, the government adjusted agricultural policies to increase and loosen the price of agricultural products step by step. As a result, the purchase prices of agricultural products have greatly increased in the 1980s and the middle of the 1990s (see Figure 5.3). In 1996, the price index of agricultural products was 5.5 times as much as that in 1978. The average growth rate per year was 9.9 percent. In the corresponding period, the retail price indices of rural industrial products were 2.9 times and 6.1 times respectively. The growth rate of farmers' actual earnings per year (the price index growth rate of agricultural products minus that of industrial products) was 3.8 percent. 
Table 5.9 National poverty relief fund and the ratio in GDP (1986-2000)

\begin{tabular}{|c|c|c|c|c|c|c|}
\hline Year & $\begin{array}{l}\text { Subsidized } \\
\text { loan } \\
\text { (million } \\
\text { Yuan) }\end{array}$ & $\begin{array}{l}\text { Food for } \\
\text { work } \\
\text { (million } \\
\text { Yuan) }\end{array}$ & $\begin{array}{l}\text { Government } \\
\text { budgetary } \\
\text { poor area } \\
\text { development } \\
\text { fund grants } \\
\text { (million Yuan) }\end{array}$ & $\begin{array}{l}\text { Total } \\
\text { (million } \\
\text { Yuan) }\end{array}$ & $\begin{array}{l}\text { The } \\
\text { proportion } \\
\text { in GDP } \\
(\%)\end{array}$ & $\begin{array}{l}\text { Per capita } \\
\text { amount in } \\
\text { impoverished } \\
\text { population } \\
(\%)\end{array}$ \\
\hline 1986 & 230 & 90 & 100 & 420 & 0.41 & 32 \\
\hline 1990 & 300 & 60 & 100 & 460 & 0.25 & 54 \\
\hline 1991 & 350 & 180 & 100 & 630 & 0.29 & 67 \\
\hline 1992 & 410 & 160 & 100 & 670 & 0.25 & 83 \\
\hline 1993 & 350 & 300 & 110 & 760 & 0.22 & 101 \\
\hline 1994 & 450 & 400 & 120 & 970 & 0.21 & 194 \\
\hline 1995 & 450 & 400 & 130 & 980 & 0.17 & 151 \\
\hline 1996 & 550 & 400 & 130 & 1080 & 0.16 & 180 \\
\hline 1997 & 850 & 400 & 280 & 1530 & 0.21 & 306 \\
\hline 1998 & 1000 & 500 & 330 & 1830 & 0.23 & 436 \\
\hline 1999 & 1500 & 650 & 430 & 2580 & 0.31 & 756 \\
\hline 2000 & & & & 2600 & 0.29 & 1182 \\
\hline
\end{tabular}

Sources: Data for 1986-1997 are from Y. Jiang and H. Gao (eds), Zhongguo caizheng fupin (The Financial Aid to the Poor by the Central Government), Beijing: Zhongguo caijing chubanshe (China Financial and Economic Publishing House), 1998. Data for 1998-1999 are from the State Council Leading Group of Poverty Alleviation and Development, quoted from Guojia tongjiju (National Bureau of Statistics of China), Zhongguo nongcun pinkun jiance baogao 2000 (A Monitoring Report on China's Rural Poverty 2000), 2000, p. 53; data for 2000 are estimates by the author.

Note: Per capita relief fund received by the impoverished people is calculated using the current year data, refer to Table 5.2.

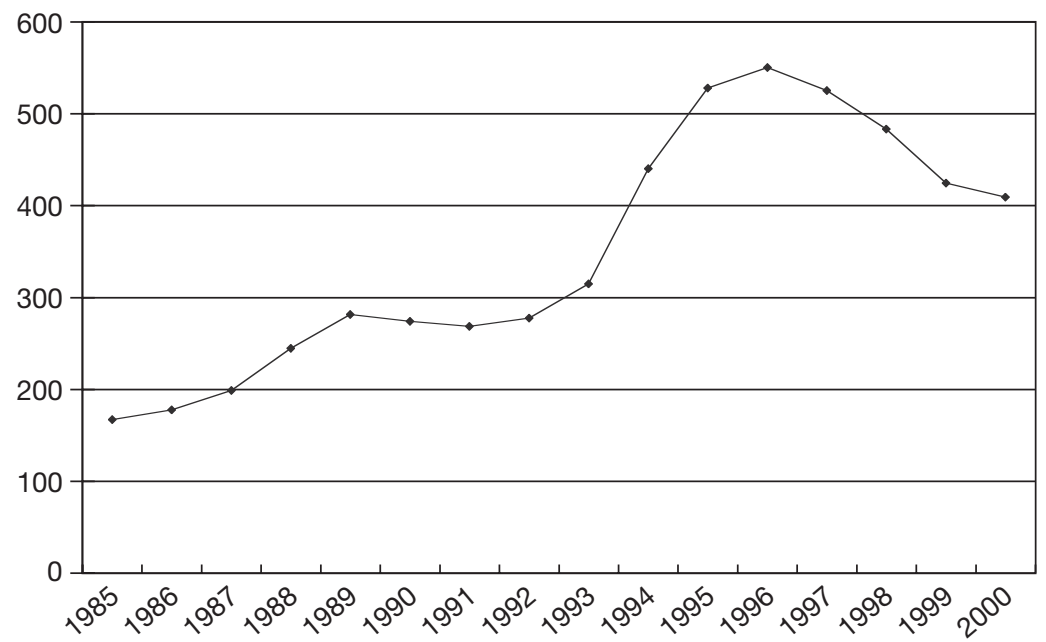

Figure 5.3 Purchase price index of agricultural products (1985-2000) (1978 as 100) Source: Guojia tongjiju, Zhongguo tongji nianjian 2001, p. 282. 


\section{China has slowed down its pace of poverty reduction since the 1990s: analysis of the reasons}

\section{The pace of poverty reduction since the 1990s}

China's per capita output and income were greatly improved in the first several years of economic reform (1978-1985), and poverty correspondently decreased by a large margin. According to the official poverty line, the rural impoverished population decreased by 200 million in the period 1978-2002; half of the decrease happened in the period 1978-1985. In this period, the impoverished population decreased by 17.86 million per year, and the annual growth rate of per capita GDP was 8.3 percent. The growth rate of the farmers' per capita consumption level and per capita income went up to 10.0 percent and 15.1 percent respectively. The rural population, especially the impoverished population, has been the main beneficiary of high economic growth in this period. However, after the second half of the 1980s (1985-1990), although China maintains a fairly high economic growth rate, there are still some indications that the pace of poverty reduction in rural areas has slowed down - the annual decrease of the impoverished population has reduced by half; the impoverished population has only decreased by 8 million annually; the average growth rate of farmers' consumption level per year is only 2.5 percent; and the average growth rate of farmers' per capita net income is only 3.0 percent (see Table 5.1).

In the 1990s (referring to the period 1990-1997), the highest average growth rate of China's per capita GDP was 9.9 percent, higher than that of the early period of reform (referring to the period 1978-1985). However, the rural impoverished population decreased annually by 5 million, less than one-third of that in the period 1978-1985. The farmers' growth rate of consumption was far lower than economic growth rate (see Table 5.1). The growth rate of per capita GDP still remained as high as 7.7 percent in the period 1997-2002, but the average decrease of the impoverished population per year was reduced to 4.36 million. The average growth rate of farmers' per capita net income was 3.8 percent, also lower than that (7.2 percent) in the reform period (1978-2002).

The decrease of China's rural impoverished population in the 1990s was a result of the decrease of the poverty line. Compared internationally, the income poverty line prescribed by the Chinese government - per capita net income below 300 Yuan (the fixed price in 1990) - is a low-standard poverty line, corresponding to only 66 percent of the international standard. If we make a vertical comparison of data, this standard tends to decrease rapidly compared with farmers' per capita net income, reducing to 26.3 percent in 2002 from 43.7 percent in 1990 , and its ratio to per capita GDP reduced to 8.2 percent in 2002 from 18.4 percent in 1990 (see Table 5.10). Based on this standard, the impoverished population estimated by the government is much less than China's real impoverished population, thus the anti-poverty achievement is overestimated (see Box 5.1). 
Table 5.10 China's official poverty line and its relative level (1978-2002)

\begin{tabular}{llll}
\hline Year & $\begin{array}{l}\text { Official poverty } \\
\text { line (Yuan, current } \\
\text { price) }\end{array}$ & $\begin{array}{l}\text { The ratio of farmers' } \\
\text { per capita net income to } \\
\text { official poverty line (\%) }\end{array}$ & $\begin{array}{l}\text { The ratio of official } \\
\text { poverty line to per } \\
\text { capita GDP (\%) }\end{array}$ \\
\hline 1978 & 100 & 74.9 & 33.0 \\
1985 & 205 & 51.6 & 24.0 \\
1990 & 300 & 43.7 & 18.4 \\
1991 & 304 & 42.9 & 16.2 \\
1992 & 317 & 40.4 & 13.9 \\
1993 & 350 & 38.0 & 11.9 \\
1994 & 440 & 36.0 & 11.2 \\
1995 & 530 & 33.6 & 10.9 \\
1996 & 580 & 30.1 & 10.4 \\
1997 & 600 & 28.7 & 9.9 \\
1998 & 625 & 28.9 & 9.9 \\
1999 & 625 & 28.3 & 9.5 \\
2000 & 625 & 27.7 & 9.5 \\
2001 & 630 & 25.4 & 8.8 \\
2002 & 627 & 25.3 & 7.9 \\
\hline
\end{tabular}

Source: Guojia tongjiju, Zhongguo tongji zhaiyao 2004, pp.18, 99 and 101.

Notes: China's current rural poverty line was calculated based upon investigating 67,000 farmer inhabitants' income and expenditure by the Rural Research Office of National Bureau of Statistics of China in 1986. China's rural poverty line in 1985 was RMB 205 Yuan net income per capita per year. The standard is adjusted year by year according to the price index since then. In 1990 the standard was RMB 300 Yuan; in 1999, RMB 625 Yuan. The standard, calculated by the fixed price in 1990, corresponds to only 66 percent of the international poverty line.

There were still 22 million people stricken by poverty in the rural areas by the end of 2000. The objective of providing 80 million poor people with adequate food and clothing promised in "The Eight-Seven Anti-poverty Plan" set down in 1994 has not been met.

In China's urban areas, the poverty rate has gradually increased since the 1990 s, especially the extreme poverty rate and dire poverty rate. According to Khan's estimate, the extreme poverty rate increased to 4.1 percent from 2.2 percent in the period 1988-1995; the dire poverty rate increased from its original 1.3 percent to 2.7 percent. He estimates that the poorest population exceeded 10 million in $2001 .{ }^{4}$ According to our estimate, the urban impoverished population has gone up to 24.03 million, which, plus the population with the lowest income (per capita income every year lower than 2497 Yuan), will account for 5 percent of the total town population. To one's fear, the number of laid-off workers and unemployed people has sharply increased, and the release of payment to employees and retirees has generally defaulted, which leads to rapid increase of the impoverished population and results in the marginalization of these people. This phenomenon not only causes serious economic problems, but also imposes grim challenges for China's society in the future. 


\section{Box 5.1 China's poverty line and discussion}

A broad gap exists between China's official poverty line and the international poverty line. The impoverished population in 1998 estimated according to China's national poverty line (per capita annual income less than 650 Yuan) accounts for 4.6 of its total population, while the povertystricken population in the same year estimated according to the international poverty line (per capita everyday living cost less that \$1) accounts for 18.5 percent of the total population, differing by about 14 percent. In Brazil, the impoverished population accounts for 22 percent of its total population according to its national poverty line, and accounts for 9.0 percent of its total population according to the international poverty line; in Bengal, the two proportions are 35.6 percent and 29.1 percent respectively; in Indonesia, the two proportions are 27.1 percent and 7.7 percent respectively. This demonstrates that the national poverty lines of the three countries are higher or slightly lower than the international poverty line. China's national poverty line is much lower than the international poverty line, which leads to the underestimation of the poverty-stricken population and the low-income population, at least 100 million less than the real number.

The following table shows China's rural poverty-stricken population estimated according to different schemes. Scheme A is the current national poverty line; per capita income is 1,000 Yuan, which is the poverty line set by scheme B; 1,500 Yuan is the poverty line set by scheme C. The result is that if scheme $\mathrm{C}$ is adopted, the estimated result is closer to the estimate made by the World Bank; if scheme B is adopted, the estimated result is between that of the World Bank and that of the national poverty line.

\begin{tabular}{lllll}
\hline $\begin{array}{l}\text { The national } \\
\text { poverty line }\end{array}$ & $\begin{array}{l}\text { Poverty line/ } \\
\text { per capita } \\
\text { GDP (\%) }\end{array}$ & $\begin{array}{l}\text { The estimated } \\
\text { rural poverty- } \\
\text { stricken } \\
\text { population } \\
(10000)\end{array}$ & $\begin{array}{l}\text { Rural poverty- } \\
\text { stricken } \\
\text { population/ } \\
\text { total rural } \\
\text { population } \\
(\%)\end{array}$ & $\begin{array}{l}\text { Rural poverty- } \\
\text { stricken } \\
\text { population/ } \\
\text { total } \\
\text { population } \\
(\%)\end{array}$ \\
\hline $\begin{array}{l}\text { Scheme A: } 650 \text { Yuan } \\
\text { Scheme B: } 1,000 \text { Yuan }\end{array}$ & 13.2 & 2713 & 3.4 & 2.1 \\
Scheme C: 1500 Yuan & 19.9 & 24044 & 30.22 & 8.2 \\
\hline
\end{tabular}


The estimating method of schemes B and C: rural impoverished population under various poverty lines is estimated according to the proportion that poverty households account for in total households. According to Annals of China's Statistics of 2002, the households with per capita income below 1,000 Yuan account for 13.3 percent of investigated households. The rural total population is $795,630,000$ according to the new statistics of population. The estimated population with income below 1,000 Yuan is calculated by performing multiplication of the two numbers. The estimated population with income below 1,500 Yuan can be obtained in the same way.

\begin{tabular}{lccc}
\hline $\begin{array}{l}\text { 2001 per capita } \\
\text { income (Yuan) }\end{array}$ & $\begin{array}{l}\text { Accounting for per } \\
\text { capita GDP (\%) }\end{array}$ & $\begin{array}{l}\text { Proportion of } \\
\text { impoverished } \\
\text { population (\%) }\end{array}$ & $\begin{array}{l}\text { Total impoverished } \\
\text { population (10000) }\end{array}$ \\
\hline $100-600$ & $1.3-8.0$ & 3.87 & 3078 \\
$600-800$ & $8.0-10.6$ & 3.88 & 3087 \\
$800-1000$ & $10.6-13.3$ & 5.47 & 4352 \\
Subtotal & & 13.22 & 10518 \\
$1000-1200$ & $13.3-15.9$ & 6.3 & 5012 \\
$1200-1300$ & $15.9-17.2$ & 3.45 & 2745 \\
$1300-1500$ & $17.2-19.9$ & 7.25 & 5786 \\
Total sum & & 30.22 & 24044 \\
\hline
\end{tabular}

\section{Characteristics of China's poverty since the 1990s}

\section{Distribution of the impoverished population in urban and rural areas}

Most of the impoverished population lives in rural areas where the degree of poverty is much deeper than that of urban habitants. One of the major reasons for this disparity is that there is a great gap between the per capita income of urban habitants and that of rural habitants, which surpasses that in common developing countries. ${ }^{5}$ In addition, poor habitants in urban areas enjoy the lowest living insurance provided by the government, while most of the impoverished population has no other living insurance besides their own land.

\section{Regional distribution of the impoverished population}

Since the 1990s, China's rural poverty gradually demonstrated regional and marginal characteristics. The poverty rate is high in the western areas of China, 
where the impoverished population is the most concentrated and the degree of poverty is the deepest across the country. According to the data given by the Rural Research Office of National Statistics Bureau in Zhongguo nongcun pinkun jiance baogao 2001 (A Monitoring Report on China's Rural Poverty (2001), in the 592 national poverty counties mentioned in 1986, about two-thirds of the total impoverished population were distributed in the eastern and middle provinces but the impoverished population of these regions has decreased rapidly since then. In 2000, 10 percent of the impoverished population was distributed in the eastern regions in a fragmentary state and 28 percent was distributed in the middle regions. The impoverished population in the western twelve provinces and areas has increased by 590,000 , mainly distributed in geographically allotted areas, accounting for 62 percent of the total impoverished population of the whole country (see Figure 5.4). According to the official poverty line, the poverty rate in the west is far higher than that in the east. In 2000, the poverty rate in middle-west provinces such as Heilongjiang, Shanxi, Inner Mongolia, Shanxi, Gansu, Yunnan, Tibet, Guizhou, Qinghai and Ningxia was higher than 10 percent, while the poverty rate in the eight eastern provinces (namely Shanghai, Beijing, Tianjin, Zhejiang and so on) was lower than 1 percent. Extreme poverty has been thoroughly diminished in these regions. Per capita income of poor farmers in the western areas is far lower than that in the east, and the rate of poverty occurrence in the west is rather high - about 30 percent in recent years. This rate is especially high when these regions are by natural disasters and overall economic decline.

\section{The multi-dimensional characteristics of poverty}

In the past two decades, the strategies of poverty reduction of the Chinese government mainly focused on eliminating income poverty, especially in national poverty counties. It is a reasonable choice of policy, and it is very necessary, too. However, as we enter the new century, the problems of new types of poverty such as human poverty and knowledge poverty are increasingly apparent, and the combined population of these is far greater than that of income poverty. Such types of poverty have gradually become major types of poverty. Human poverty refers to the lack of basic human ability, such as illiteracy, malnutrition, short life expectancy, low level of health condition of mothers and infants and the harm caused by preventable diseases. Knowledge poverty is a new form of poverty when humans enter the knowledge based society in the twenty-first century, which can be defined as the problems caused by people's lack of the abilities to obtain information, communicate with each other, utilize and create knowledge and information, or the lack of basic rights and chances to obtain these abilities.

These three types poverty are not independent of one another, but interrelated. The impoverished population is not always faced with only one type of poverty, but the problems of multi-dimensional and interdependent poverty. Figure 5.5 is a three-dimensional coordinate map weighing poverty. It can differentiate 


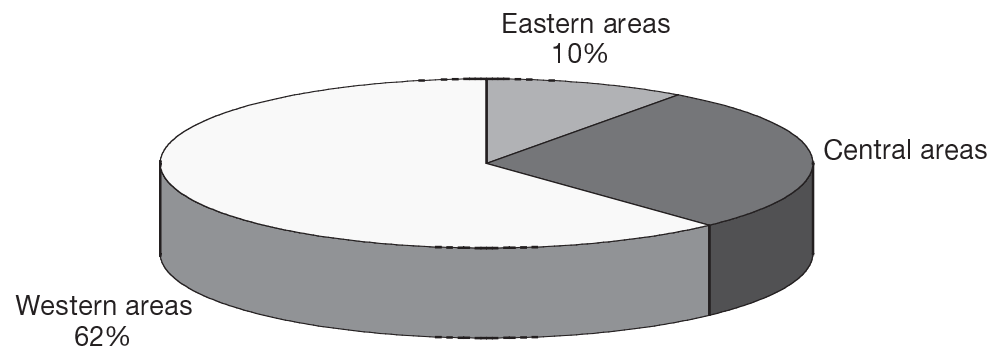

Figure 5.4 Regional distribution of China's rural impoverished population (2000)

Source: National Bureau of Statistics of China, Zhongguo nongcun pinkun jiance baogao 2001 (A Monitoring Report on China's Rural Poverty 2001).

various types of poverty. The impoverished population faced with the three types of interrelated poverty is inside the cube. One of the indexes weighing status of human poverty is the human poverty index (HPI). ${ }^{6}$ China's HPI is shown in Figure 5.6. In addition, China's status of knowledge poverty is reflected by the great gap among different regions (see Figure 5.7, Table 5.11).

\section{Factors affecting China's poverty reduction since the 1990s}

The relationship between economic growth and poverty reduction is not simple. It is not the speed of economic growth but the quality of economic growth that actually plays an important role. Since the 1990s, the economic development of many developing countries, especially in east Asia, demonstrates that although economic growth plays an important supporting role in social development, too rapid economic growth will still produce damaging effects on the environment and resources. Moreover, if the economic growth is not based on good environmental systems, various marketing distortions, inefficient investments and prevailing corruption will come into being. The public, especially the impoverished population, will be deprived of the ability and chance to participate in marketing activities and political decision-making. Therefore, we must comprehensively survey the complex relationship between economic growth and poverty reduction.

Although China's economy has been increasing very rapidly since the 1990s, the quality of its economic growth is declining and the income allocation is unfair, which results in a decreased proportion of benefits being obtained by the impoverished population. This is an important reason for China to slow down its pace of poverty reduction.

\section{Quality of economic growth has declined: rapid economic growth has not helped to decrease poverty}

China's growth rate of per capita GDP in the 1990s has created the highest record in history, but why is the achievement of poverty reduction so limited? 


\section{Economic and social transformation in China}

Knowledge poverty

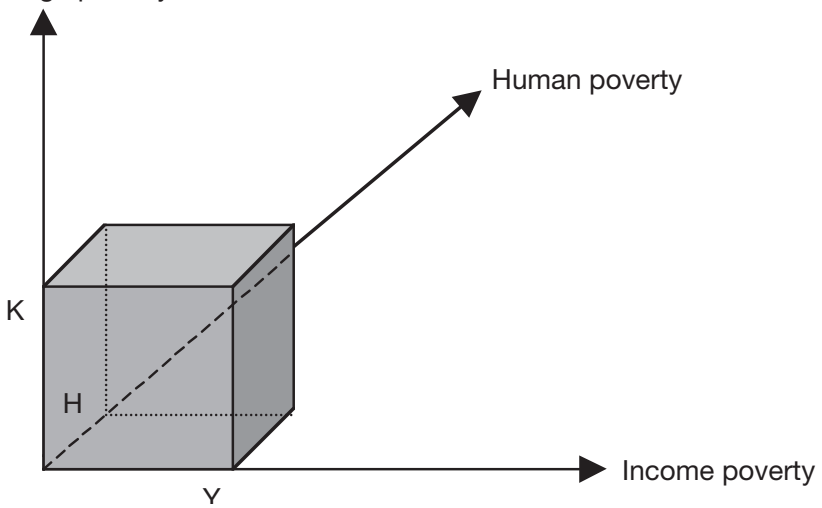

Figure 5.5 Multi-dimensional framework of poverty

Sources: UNDP, Poverty Report: Overcoming Human Poverty 2000, New York: Oxford University Press, 2000.

Notes: Y refers to average status of income poverty; K refers to average status of knowledge poverty; $\mathrm{H}$ refers to average status of health poverty.

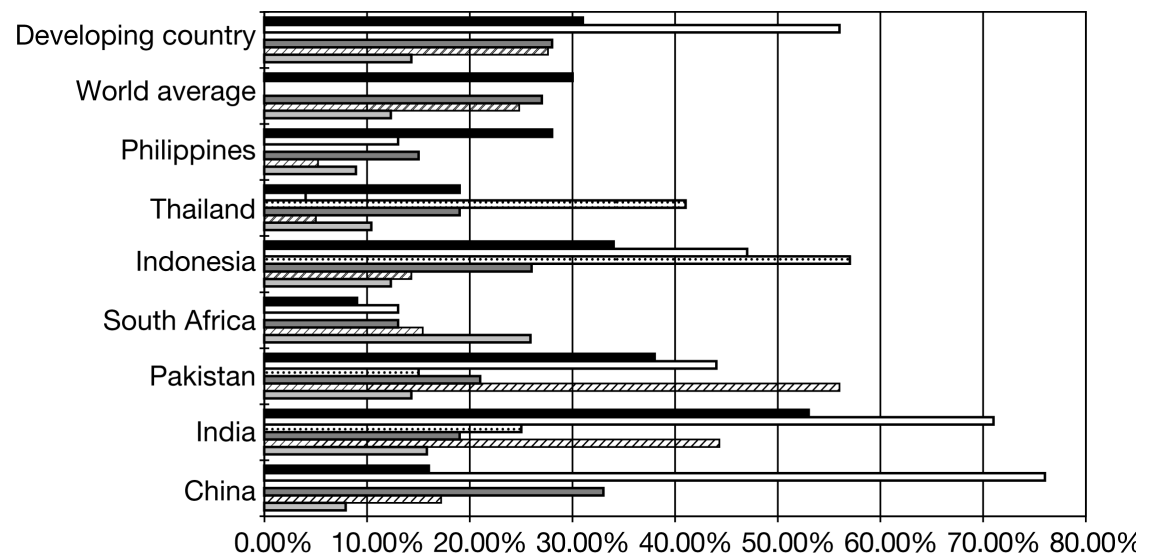

People without access to safe water

$\square$ People without access to sanitation

$\square$ Population who cannot live longer than 40 years $\square$ Illiterate rate, adults

Q. People without access to medical care

Under-weighed rate, children under 5 years old

Figure 5.6 Human poverty index (1998)

Sources: UNDP, Poverty Report: Overcoming Human Poverty 2000, New York: Oxford University Press, 2000. 


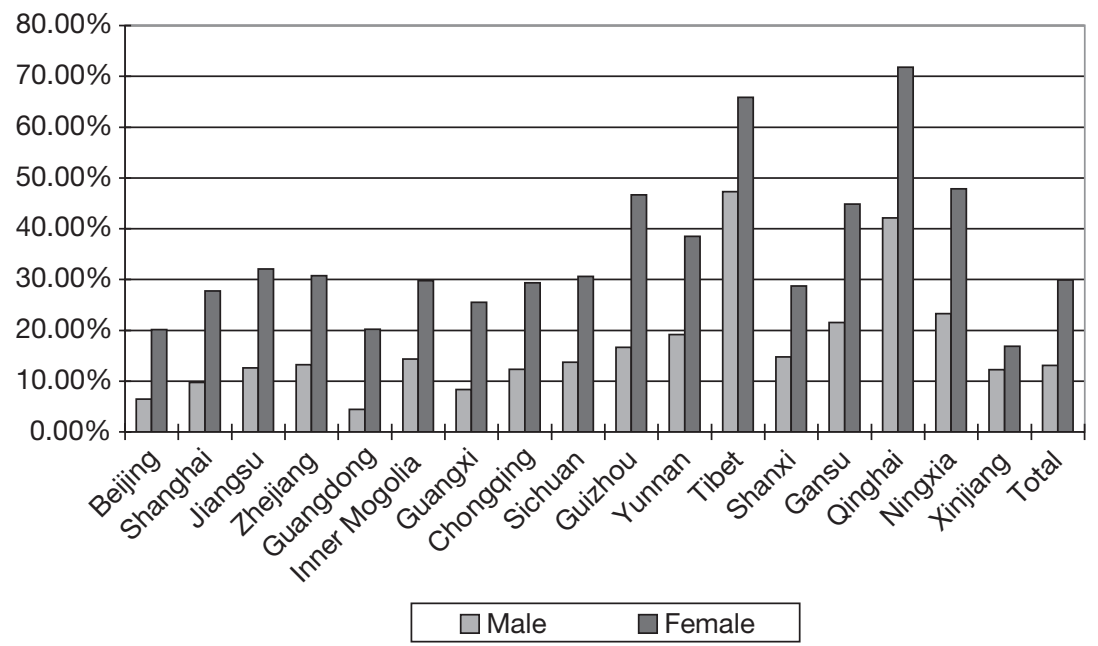

Figure 5.7 Proportion of illiterates and semiliterates above 15 years (1997)

Sources: Guojia tongiju (National Bureau of Statistics of China), Zhongguo renkou tongji nianjian 1998 (China's Population Yearbook 1998), Beijing: Zhongguo tongji chubanshe (China Statistics Press), 1998, p. 39.

Table 5.11 Ranking of comprehensive knowledge developing index of different regions (1998)

\begin{tabular}{llll}
\hline & Eastern areas & Central areas & Western areas \\
\hline $\begin{array}{l}\text { High level } \\
\left(I_{t} \geq 150\right)\end{array}$ & Beijing (606.05) & & \\
& $\begin{array}{l}\text { Shanghai (529.03) } \\
\text { Tianjin (283.70) } \\
\text { Guang Dong (212.74) }\end{array}$ & & \\
& Fujian (156.48) & & \\
& Jiangsu (154.55) & & \\
Medium-high level & Hainan (127.64) & & \\
$\left(150>I_{t} \geq 100\right)$ & Liaoning (126.69) & & \\
& Zhejiang (122.71) & & Shaanxi (88.05) \\
Medium-low level & Shandong (82.05) & Jilin (99.53) & Xinjiang (65.85)? \\
$\left(100>I_{t} \geq 75\right)$ & Hebei (75.69) & Hubei (92.18) & Chongqing (63.71) \\
& & Heilongjiang (84.63) & Gansu (58.32) \\
Low level $\left(I_{t}<75\right)$ & Guangxi (50.88) & Hunan (69.72) & Ningxia (54.70) \\
& & Shanxi (64.27) & Sichuan (51.49) \\
& & Henan (63.74) & Yunnan (48.75) \\
& & Jiangxi (61.04) & Qinghai (44.18) \\
& & Anhui (57.69) & Inner Mongolia (56.59) \\
& & & Tibet (31.99) \\
\hline
\end{tabular}

Sources: A. Hu and Y. Xiong, "Woguo zhishi fazhan diqu chaju yanjiu: tedian, duice he chengyin" (Analysis of Regional Disparities of China's Knowledge Development: Characteristics, Causes and Countermeasures), Guanli Shijie (Management World), 2000, Issue 3. 


\section{Economic and social transformation in China}

This is mainly because the quality of economic growth has declined, and China's poverty stratum has not directly benefited from the high growth rate of the gross economy, which can be shown by the following points.

The growth of per capita income and consumption lags far behind the growth of GDP per capita. In the past two decades, a rather complex relationship has emerged between China's growth rate of per capita income and that of per capita GDP (see Figure 5.8). In the period 1978-1985, the growth rate of per capita GDP was 8.4 percent, which is calculated according to a fixed price (as are the following rates). The growth rates of per capita consumption level and per capita net income of rural residents were 9.7 percent and 15.1 percent respectively, higher than the growth rate of per capita GDP, also much higher than the growth rate of per capita consumption level of urban residents $(1.3$ percent), which demonstrates that the broad masses of farmers have directly benefited from the economic growth in the early stage of reform. In the period 1985-2001, the growth rate of per capita GDP has separated from that of per capita income: the growth rate of per capita consumption level of rural and urban habitants and the growth rate of per capita income of rural people are

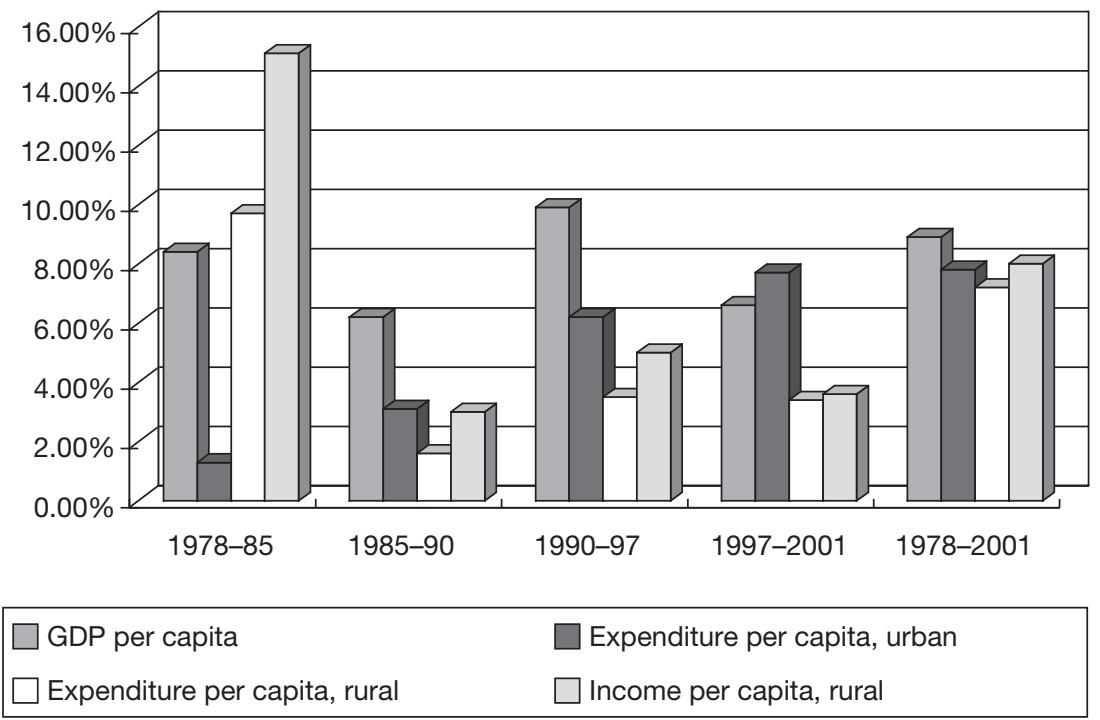

Figure 5.8 Annual growth rate of GDP and consumption level per capita, urban and rural people (1978-2001)

Sources: Data of per capita consumption (1978-1999) are quoted from Guojia tongjiju (National Bureau of Statistics of China), Xinzhongguo wushinian tongji ziliao huibian (Comprehensive Statistical Data and Materials on 50 Years of New China), Beijing: Zhongguo tongji chubanshe (China Statistical Press), 1999; the rest of the data are quoted from Guojia tongjiju, Zhongguo tongji nianjian 2002.

Note: Data are calculated in comparable prices. 
obviously lower than that of per capita GDP (except during the period 1997-2001 when the growth rate of per capita income of urban habitants was slightly higher than that of per capita GDP).

The proportion of agricultural production value in GDP has greatly declined. The ratio of agricultural labor productivity to national average labor productivity has declined. The ratio of farmers' income per capita to GDP per capita has declined. The proportion of farmers' agricultural income in their total income has continuously declined.

The proportion of agricultural production value in GDP has been decreasing continuously. Calculated at current prices, the proportion of agriculture in GDP was 28.4 percent in 1985 and has decreased to 18.1 percent in 2002, declining 10.3 percentage points. The proportion of the agricultural labor force in the total labor force had been decreasing until 1995. Since then, the proportion has stopped at about 50 percent (see Figure 5.9), which leads to the rapid decrease of the ratio between agricultural productivity and national average productivity after 1985. Although the ratio has slightly increased in the middle of 1990s, the obvious trend of declining has arisen after that year. This reflects the decrease of relative agricultural productivity. The ratio between farmers' income per capita and GDP has also been dropping continuously. The highest ratio was 46.5 percent in 1985 , which has rapidly decreased since then, decreasing to 31.1 percent in 1994, and then fluctuating around that level after that year (see

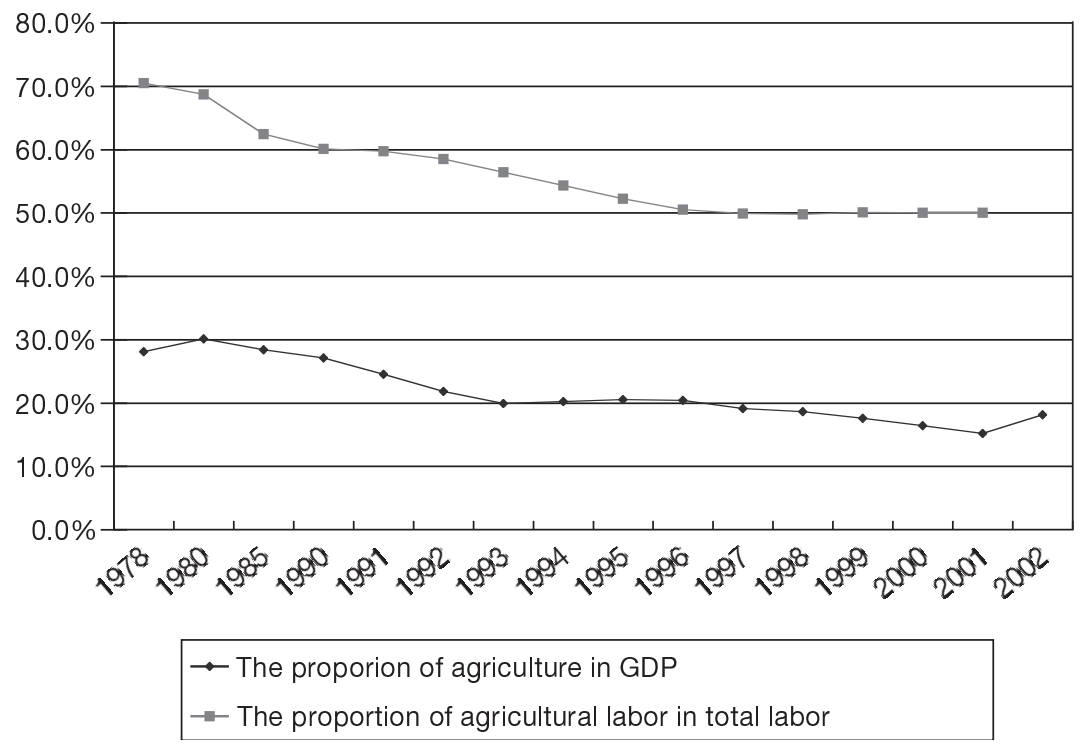

Figure 5.9 Status of agriculture in the national economy (1978-2002)

Source: Guojia tongjiju, Zhongguo tongji nianjian 2002. 


\section{Economic and social transformation in China}

Figure 5.10). In terms of the sources of farmer's per capita annual net income, agricultural income accounted for 75 percent of total income in 1985, and the proportion decreased to 49.9 percent in 2000 , decreasing 33.5 percentage points (see Figure 5.11). Generally speaking, agriculture is still the main income source of farmers. This shows that the gap between per capita GDP and farmers' per capita net income and per capita real consumption level has obviously become larger, which produces a large negative impact on poverty reduction. This analysis partly explains the reasons for China's slow pace of rural poverty reduction after the middle of the 1980s.

The opportunities for employment in rural areas are declining. Since the 1990s, the opportunities for employment created in urban areas are far more than those in rural areas. In the period 1990-2001, the growth rate of urban employment was 40.5 percent, while that in rural areas was only 2.9 percent; in the period 1978-1985, the number of people who were employed in rural areas had increased by 21 percent (see Figure 5.12). In the period 1990-2001, rural labor force decreased by 6.2 percent. The development of village and township enterprises had undergone serious setbacks. The number of people who were employed decreased by a large margin, decreasing by 8 million just in the period from 1996 to 1998. Because large quantities of employees had been laid off and lost their jobs, there is a limit for rural labor to enter into cities. This has produced a very serious impact on rural poverty reduction. This will be reflected as follows: first, the pressure of employment competition will become larger; and secondly,

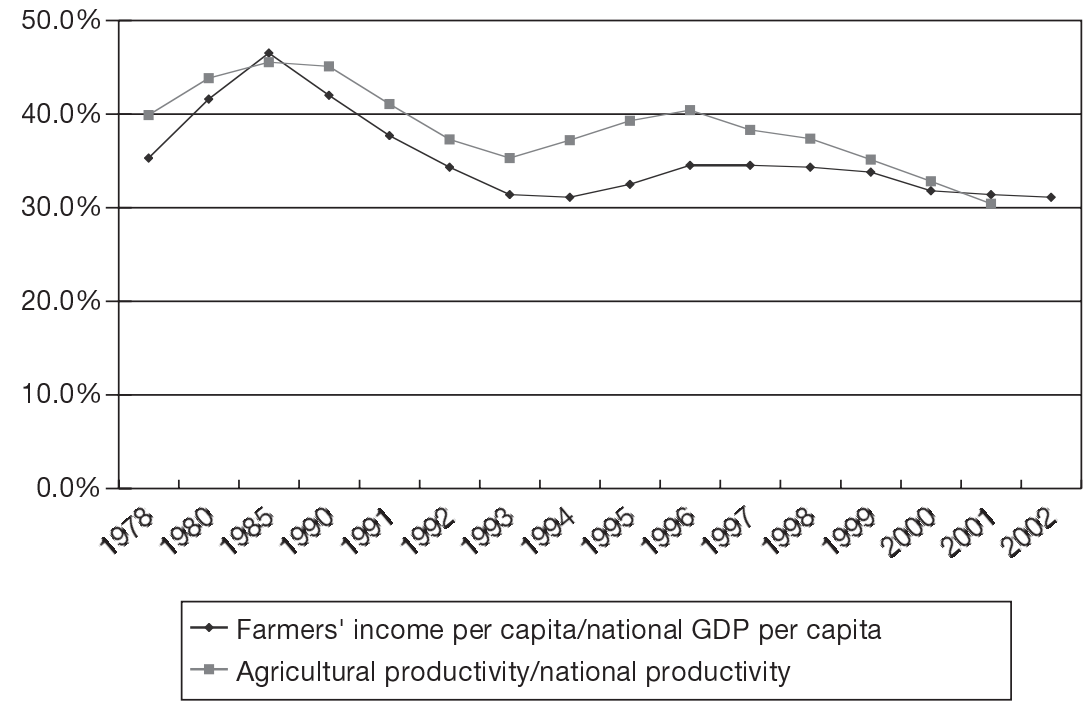

Figure 5.10 Farmers' income and agricultural labor productivity (1978-2002)

Sources: The proportion between farmers' per capita income and national per capita GDP is calculated according to the data of Guojia tongjiju, Zhongguo tongji nianjian 2002; the ratio between agricultural productivity and national productivity is calculated according to the data of Figure 5.9. 
the remitting income flowing from cities to rural areas will decline. Since many cities set a limit on rural labor forces flowing into cities or adopt discriminatory policies (such as the requirement of formal residential identity), the wages of these workers will be directly influenced. In addition, the living costs of the children of these new migrant families in cities will increase.

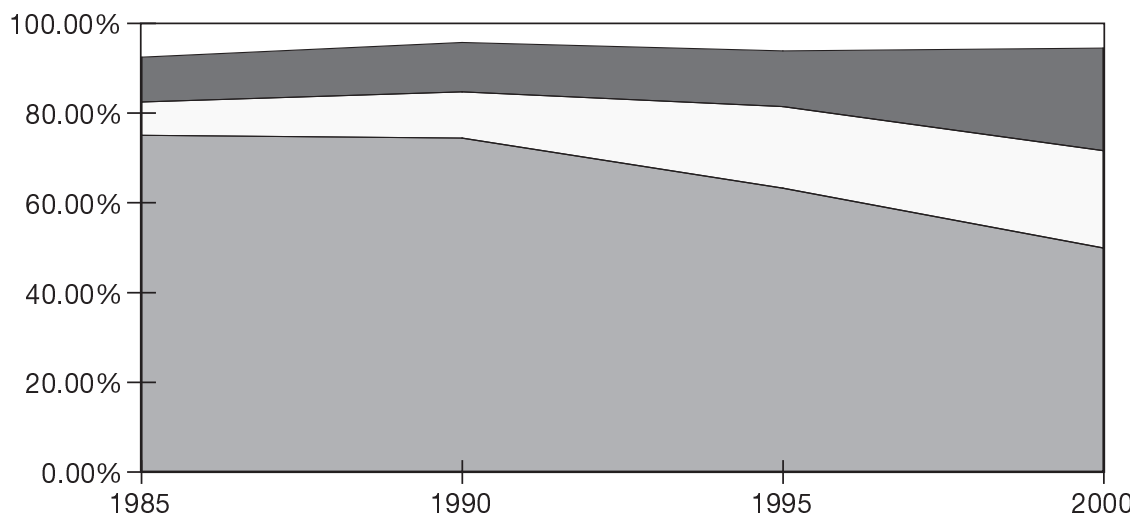

\section{Primary industry $\quad \square$ Secondary industry $\quad \square$ Tertiary industry}

Figure 5.11 Proportions of various income sources in farmers' per capita net income (1985-2000)

Source: Guojia tongjiju, Zhongguo tongji nianjian 2002.

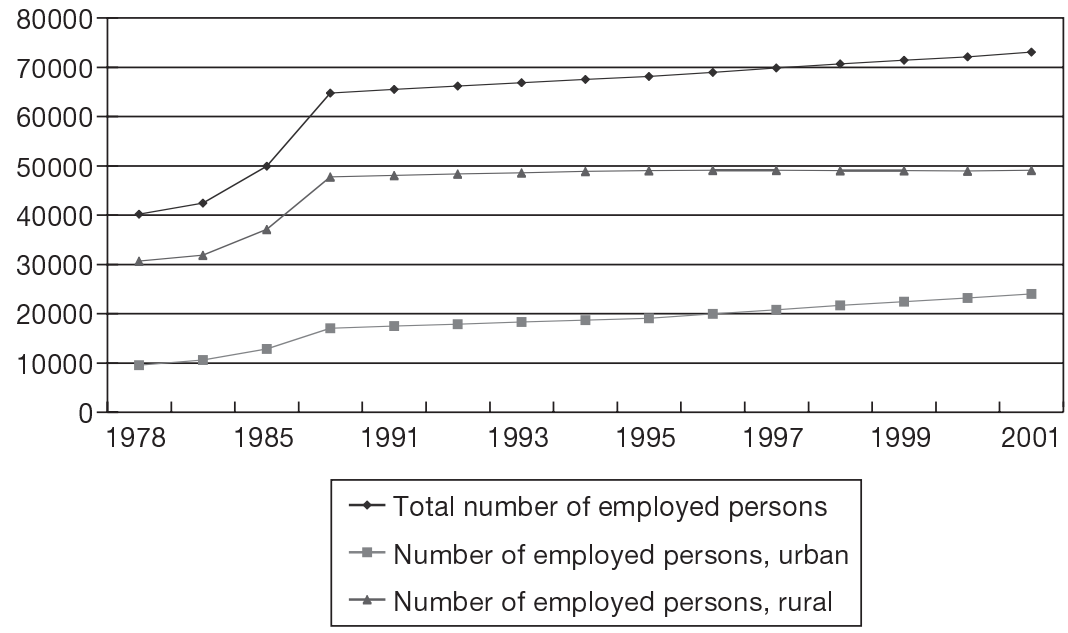

Figure 5.12 Status of employment since reform (1978-2001)

Source: Guojia tongjiju, Zhongguo tongji nianjian 2002. 
A great decrease in the prices of agricultural products increases the loss of exchange volume of agricultural products. In recent years, people have not only suffered from risks caused by natural disasters, but have also incurred the marketing risks of "price impact" caused by four successive years of great decreases in the prices of agricultural products. Taking the price in 1996 as the base, the accumulated decrease rate of the purchase price level of national agricultural products was 25.6 percent by 2000 . In the period $1997-2000$, the trade volume of national agricultural products suffered the loss of 41.1 billion Yuan, 8100 billion Yuan, 134.4 billion Yuan and 44.8 billion Yuan respectively because of the price decrease, and the accumulative total loss was 301.3 billion Yuan (see Table 5.12). This shows that the broad masses of farmers have been the most serious victims of deflation. The price fluctuation in the macro-economy directly influences farmers' income.

\section{Increasing inequality in distribution}

Factors affecting the poverty occurrence rate include not only income growth, but also income distribution. Even though the growth rate of per capita income is lower than that of per capita GDP, if the degree of income inequality does not deteriorate, rapid economic growth can still play a positive role in poverty reduction. Since 1985, the degree of inequality between urban areas and rural areas, among different regions, and even within urban areas has intensified, which produces a great negative impact on poverty reduction.

Great gaps exist between urban residents and rural residents in terms of per capita income, per capita consumption, revenue, transferred payment and public services, and so on.

Table 5.12 Volume of national agricultural products trade and the loss caused by price decreases (1996-2000)

\begin{tabular}{llll}
\hline Year & $\begin{array}{l}\text { The volume of } \\
\text { national agricultural } \\
\text { products trade (a) }\end{array}$ & $\begin{array}{l}\text { The growth rate of } \\
\text { General Purchasing } \\
\text { Price Index of Farm } \\
\text { Products (\%) (b) }\end{array}$ & $\begin{array}{l}\text { The price losses of } \\
\text { sold agricultural } \\
\text { products } \\
\text { (100 million Yuan) }\end{array}$ \\
\hline 1996 & 7600 & & \\
1997 & 9136 & -4.5 & 411 \\
1998 & 10123 & -8.0 & 810 \\
1999 & 11018 & -12.2 & 1344 \\
2000 & 12443 & -3.6 & 448 \\
$1997-2000$ & 33620 & -22.6 & 3013 \\
\hline
\end{tabular}

Sources: (a) Guojia tongjiju, Zhongguo tongji zhaiyao 2001, p. 145; (b). Guojia tongjiju, Zhongguo tongji nianjian 2001, p. 281.

Notes: The volume of national agricultural products trade refers to the sum of transaction value of grain and oil, meat, poultry and eggs, aquatic products, vegetables, dried and fresh fruits. The price losses of sold agricultural products are (a) times (b). 
The gap of per capita income between urban residents and rural residents has experienced a process of shrinking and then enlarging since the policy of reform has been adopted. The income distribution between urban areas and rural areas has deteriorated, which has directly resulted in the increase of the poverty rate to a great extent. What is demonstrated in Figure 5.13 is the proportion (calculated at current prices) between per capita disposable income and per capita consumption in urban areas and that in rural areas, from which we can see that there exists great gap between urban areas and rural areas. Calculated at current prices, the ratio of per capita disposable income of urban households to that of rural households is 2.57 times in 1978, falling to 1.85 times in 1985, but increasing to 2.9 times in 2001,71 percent higher than that in 1978. If calculated at a constant price in 1978, the ratio of per capita income in urban areas to that in rural areas has declined to 1.53 times in 1985 and increased to 2.12 times in 2001 .

The fiscal distribution system with its high inequality effects has sharpened income inequality between the urban population and the rural population. The per capita income of rural households is analogous to two-fifths of that of urban households. However, in rural residents' total income, the proportion of transferred income acquired from the country and the collective is far lower than that of urban residents (see Table 5.13). Moreover, rural residents have to pay tax that is far more than fiscal transferred income. By comparison, urban households can obtain various types of fiscal allowances and become beneficiaries of net subsidies.

Great gaps exist between urban residents and rural residents in terms of enjoying public services. The Chinese government adopts public service policies

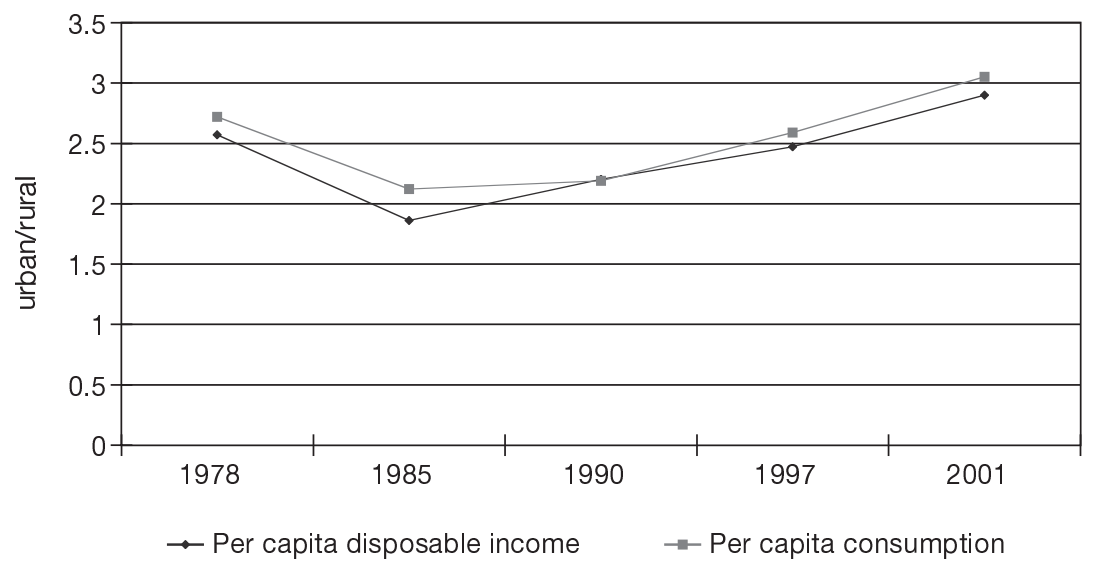

Figure 5.13 Ratio of per capita disposable income and per capita consumption expenditure of urban residents to those of rural residents (1978-2001)

Sources: Calculated according to Guojia tongjiju, Xinzhongguo tongji huibian.

Note: Calculation in current prices. 
Table 5.13 Income and transferred income per capita of urban households and rural households (1985-2003)

\begin{tabular}{|c|c|c|c|c|c|c|}
\hline \multirow[t]{2}{*}{ Year } & \multicolumn{3}{|c|}{ Urban households } & \multicolumn{3}{|c|}{ Rural households } \\
\hline & $\begin{array}{l}\text { Per capita } \\
\text { total annual } \\
\text { income } \\
\text { (Yuan) }\end{array}$ & $\begin{array}{l}\text { Per capita } \\
\text { transfer } \\
\text { income } \\
\text { (Yuan) }\end{array}$ & $\begin{array}{l}\text { Transfer } \\
\text { incomel } \\
\text { total income } \\
\text { per capita } \\
(\%)\end{array}$ & $\begin{array}{l}\text { Per capita } \\
\text { annual } \\
\text { income } \\
\text { (Yuan) }\end{array}$ & $\begin{array}{l}\text { Per capita } \\
\text { transfer } \\
\text { income } \\
\text { (Yuan) }\end{array}$ & $\begin{array}{l}\text { Transfer } \\
\text { incomel } \\
\text { annual } \\
\text { income per } \\
\text { capita }(\%)\end{array}$ \\
\hline 1985 & 748.92 & 65.88 & 8.8 & 547.31 & n.a. & n.a \\
\hline 1990 & 1522.79 & 250.01 & 16.4 & 990.38 & n.a & n.a \\
\hline 1995 & 4288.09 & 734.83 & 17.1 & 2337.87 & 65.77 & 2.8 \\
\hline 2000 & 6316.81 & 1211.86 & 19.2 & 3146.21 & 147.59 & 4.7 \\
\hline 2001 & 6907.08 & 1362.39 & 19.7 & 3306.92 & 162.83 & 4.9 \\
\hline 2003 & 9061.22 & 2112.20 & 23.31 & 3582.42 & 136.75 & 3.8 \\
\hline
\end{tabular}

Sources: Guojia tongiju, Zhongg tongji nianjian 2004 (China Statistical Yearbook 2004), pp. 359 and 380 .

Notes: All data are in current prices.

that are preferable to cities. The rural population accounts for two-thirds of the total population now, but only one-seventh to one-tenth of the fiscal expenditure of the government is spent directly on the rural population, which results in rural areas lagging far behind urban areas in public services such as basic education, fundamental medical care and family planning, and in areas of infrastructure such as irrigation, roads and communication, and so on. The low level of rural public services not only restricts the improvement of rural residents' living standards, but also restricts the developing abilities and opportunities of rural residents, which makes them easily affected by poverty.

The gap among the per capita income of farmers in different regions is enlarging. The Impoverished population in western areas is very large and the degree of poverty is very deep. Accordin६ $: 0$ the data of Zhongguo nongcun pinkun jiance baogao (A Monitoring Report on China's Rural Poverty) by the Rural Research Office of National Statistical Bureau, the ratio between the per capita income of farmers in the east, in the middle and in the west is 1.27:1.05:1.00, increasing to $1.92: 1.30: 1.00$ in 2000. The Gini coefficient of farmers' per capita net income in poverty counties is 0.3274 in 2000, higher than that in 1999. The main reason is that poverty counties in the middle and west areas were badly hit by serious droughts, thus most counties had negative growth of income. By comparison, the per capita net income of farmers has increased again on the basis of the original high level in poverty counties in the eastern provinces, such as Hainan and Fujian.

The gap in the per capita net income in rural areas among different provinces presents a trend of enlarging. According to the research made by Zhang Ping, ${ }^{7}$ the Gini coefficient in 1988 was 0.19, increasing to 0.23 in 1995 . 
Furthermore, in terms of income structure, the proportion of non-agricultural income in total income of farmers in the east is much higher than that in the middle and the west (see Figure 5.14), which shows that the farmers in the east area were able to get more benefits from non-agricultural industries.

Inequality of income distribution within rural regions is enlarging. Income inequality within China's rural areas was not large before the reform. According to the estimate of a sample investigation made by the National Statistical Bureau, the Gini coefficient of rural residents' income in 1978 was 0.21 to $0.22 .^{8}$ The Gini coefficient in 1978 estimated by Adelman and Sunding was 0.22. ${ }^{9}$ The Gini coefficient in 1978 estimated by Mark Selden was about $0.28 .^{10}$ The income gap between rural residents has been shrinking in the period from 1978 to 1982 . The Gini coefficient during this period has decreased to 0.22 from 0.32 , according to the estimate by Ahmad and Wang. ${ }^{11}$

The income gap within China's rural areas has enlarged since the middle of the 1980s. According to the estimate made by the National Statistical Bureau, the Gini coefficient of per capita income of rural households has increased to 0.34 in 1995 from 0.23 in 1985, and it was 0.35 in 2000. Ravallion and Chen estimated that the Gini coefficient increased to 0.34 in 1995 from 0.3 in 1988 (see Table 5.14). Though the poverty incidence rate experienced a fluctuation of falling, rising and falling (see Table 5.15), inequality had experienced falling, rising, falling and rising (see Table 5.16)

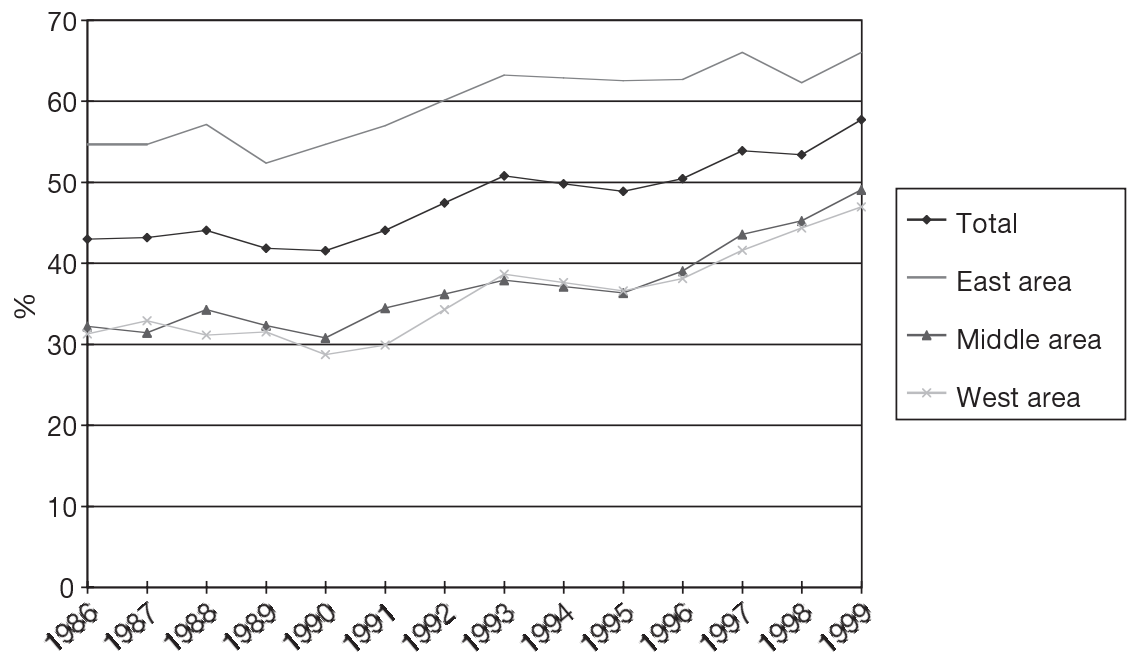

Figure 5.14 Proportion of income from non-agricultural industries of rural residents (1986-1999)

Source: Guojia tongjiju (National Bureau of Statistics of China, Zhongguo nongcun pinkun jiance baogao 2001 (A Monitoring Report on China's Rural Poverty 2001), 2001. 
Table 5.14 Gini indices of income inequality in China (1980-2002)

\begin{tabular}{|c|c|c|c|c|}
\hline & \multirow[b]{2}{*}{ Rural } & \multirow[b]{2}{*}{ Urban } & \multicolumn{2}{|l|}{ National } \\
\hline & & & $\begin{array}{l}\text { Without cost of } \\
\text { living adjustment }\end{array}$ & $\begin{array}{l}\text { With cost of living } \\
\text { adjustment }\end{array}$ \\
\hline 1980 & 24.99 & n.a. & n.a. & n.a. \\
\hline 1981 & 24.73 & 18.46 & 30.95 & 27.98 \\
\hline 1982 & 24.40 & 16.27 & 28.53 & 25.91 \\
\hline 1983 & 25.73 & 16.59 & 28.28 & 26.02 \\
\hline 1984 & 26.69 & 17.79 & 29.11 & 26.89 \\
\hline 1985 & 26.80 & 17.06 & 28.95 & 26.45 \\
\hline 1986 & 28.48 & 20.66 & 32.41 & 29.20 \\
\hline 1987 & 28.53 & 20.20 & 32.38 & 28.90 \\
\hline 1988 & 29.71 & 21.08 & 33.01 & 29.50 \\
\hline 1989 & 30.96 & 24.21 & 35.15 & 31.78 \\
\hline 1990 & 29.87 & 23.42 & 34.85 & 31.55 \\
\hline 1991 & 31.32 & 23.21 & 37.06 & 33.10 \\
\hline 1992 & 32.03 & 24.18 & 39.01 & 34.24 \\
\hline 1993 & 33.70 & 27.18 & 41.95 & 36.74 \\
\hline 1994 & 34.00 & 29.22 & 43.31 & 37.60 \\
\hline 1995 & 33.98 & 28.27 & 41.50 & 36.53 \\
\hline 1996 & 32.98 & 28.52 & 39.75 & 35.05 \\
\hline 1997 & 33.12 & 29.35 & 39.78 & 35.00 \\
\hline 1998 & 33.07 & 29.94 & 40.33 & 35.37 \\
\hline 1999 & 33.91 & 29.71 & 41.61 & 36.37 \\
\hline 2000 & 35.75 & 31.86 & 43.82 & 38.49 \\
\hline 2001 & 36.48 & 32.32 & 44.73 & 39.45 \\
\hline 2002 & n.a. & 32.65 & n.a. & n.a. \\
\hline
\end{tabular}

Source: M. Ravallion and Sh. Chen, China's (Uneven) Progress Against Poverty, July 2004. Available at www.worldbank.org.cn/chinese/content/poverty-04.pdf (accessed June 17, 2005).

The fiscal distribution system with its high inequality effect not only intensifies income inequality between the urban population and the rural population, but also intensifies income inequality between poor people and non-poor people in rural areas. In rural areas, the tax paid by the group of people with the lowest average income accounts for the highest proportion, 3.4 times as much as that of the group of people with the highest income (see Table 5.17).

The preceding analysis shows that high economic growth alone cannot automatically solve the problems of income inequality and poverty; the fruits brought by economic growth and the opening up policy cannot be automatically shared by all the people. On the contrary, unequal economic growth with low quality restricts people's opportunity to share the fruits of growth. The distribution policy of the government intensifies this inequality phenomenon. The fiscal expenditure and public services policies of the government are seriously preferential to cities and beneficial to urban residents. Urban residents and rural residents have different chances to obtain education and medical care. Economic policies are preferential to coastal areas, and are not beneficial to the development of inland 
Table 5.15 National urban and rural poverty incidence rate and poverty population (1980-2002)

\begin{tabular}{llllllc}
\hline Year & \multicolumn{2}{l}{ Poverty incidence rate (\%) } & \multicolumn{2}{c}{ Poverty population (10,000) } \\
\cline { 2 - 6 } & Rural & Urban & National & Rural & Urban & National \\
\hline 1980 & 75.70 & & 62.0 & 51455 & & 61197 \\
1981 & 64.67 & 6.01 & 52.84 & & & \\
1982 & 47.78 & 2.16 & 38.14 & & & \\
1983 & 38.38 & 4.56 & 30.42 & & & \\
1984 & 30.39 & 1.27 & 24.11 & & & 18577 \\
1985 & 22.67 & 1.08 & 17.55 & 18308 & & \\
1986 & 23.50 & 3.23 & 18.53 & & & \\
1987 & 21.91 & 1.62 & 16.77 & & & \\
1988 & 23.15 & 2.07 & 17.71 & & & \\
1989 & 29.17 & 7.05 & 23.37 & & 774 & 25325 \\
1990 & 29.18 & 2.58 & 22.15 & & 517 & 25666 \\
1991 & 29.72 & 1.66 & 22.16 & 25149 & 361 & 24313 \\
1992 & 28.18 & 1.33 & 20.75 & 23952 & 331 & 23715 \\
1993 & 27.40 & 1.01 & 20.01 & 23384 & 305 & 20386 \\
1994 & 23.32 & 1.19 & 17.01 & 19981 & 405 \\
1995 & 20.43 & 0.85 & 14.74 & 17559 & 294 & 17853 \\
1996 & 13.82 & 0.61 & 9.79 & 11759 & 223 & 11982 \\
1997 & 13.33 & 0.70 & 9.30 & 11221 & 276 & 11497 \\
1998 & 11.58 & 1.16 & 8.10 & 9629 & 477 & 10106 \\
1999 & 11.40 & 0.57 & 7.63 & 9352 & 245 & 9597 \\
2000 & 12.96 & 0.63 & 8.49 & 10476 & 284 & 10760 \\
2001 & 12.49 & 0.50 & 7.97 & 9937 & 235 & 10171 \\
2002 & & 0.54 & & & & \\
\hline
\end{tabular}

Source: M. Ravallion and Sh. Chen, China's (Uneven) Progress Against Poverty, July 2004.

Notes: Rural poverty line is 850 Yuan per person per year in 2002; urban poverty line is 1200 Yuan per person per year. National poverty incidence rate is a weighted means of rural and urban poverty incidence rates.

Table 5.16 Income inequality and income growth rate (1981-2001)

\begin{tabular}{|c|c|c|c|c|c|}
\hline \multirow[t]{2}{*}{ Period } & \multirow[t]{2}{*}{$\begin{array}{l}\text { Inequality } \\
\text { Change }\end{array}$} & \multirow{2}{*}{$\begin{array}{l}\text { Gini index } \\
\text { (annualized } \\
\text { log difference } \\
\% / \text { year) }\end{array}$} & \multicolumn{3}{|c|}{$\begin{array}{l}\text { Mean household income } \\
\text { (annualized log difference \%/year) }\end{array}$} \\
\hline & & & National & Rural & Urban \\
\hline 1981-1985 & Falling & -1.12 & 8.87 & 14.0 & 5.6 \\
\hline 1986-1994 & Rising & 2.81 & 3.10 & 1.7 & 5.3 \\
\hline 1995-1998 & Falling & -0.81 & 5.35 & 7.8 & 4.3 \\
\hline 1999-2001 & Rising & 2.71 & 4.47 & 3.1 & 7.4 \\
\hline
\end{tabular}

Source: Ravallion and Chen, China's (Uneven) Progress against Poverty. 
Table 5.17 Tax proportion of farmers by different income groups (1999)

\begin{tabular}{lclll}
\hline $\begin{array}{l}\text { Income of } \\
\text { group (Yuan) }\end{array}$ & $\begin{array}{l}\text { Average income } \\
\text { (Yuan) (a) }\end{array}$ & $\begin{array}{l}\text { Income } \\
\text { Components }(b)\end{array}$ & $\begin{array}{l}\text { Tax/fee ratio } \\
(c)\end{array}$ & $\begin{array}{l}\text { Tax/fee ratio } \\
(d)\end{array}$ \\
\hline$<800$ & 522.40 & 86.52 & 17.53 & 11.51 \\
$800-1600$ & 1204.91 & 82.22 & 10.35 & 6.75 \\
$1600-2400$ & 1970.35 & 72.98 & 6.71 & 4.12 \\
$2400-3200$ & 2766.30 & 60.18 & 5.22 & 2.90 \\
$3200-4000$ & 3570.66 & 46.41 & 4.27 & 2.18 \\
$4000-6000$ & 4804.11 & 41.83 & 3.42 & 1.44 \\
$6000-8000$ & 6868.57 & 30.51 & 3.89 & 1.16 \\
$8000-12000$ & 9532.26 & 22.32 & 2.91 & 0.32 \\
$>12000$ & 23594.92 & 6.89 & 5.14 & 0.30 \\
\hline
\end{tabular}

Sources: Y. Lin and T. Ren et al., "Issue of Chinese Farmers' Tax Burden," China Center for Economic Research, Peking University, June 2002

Notes:

(a) Average income indicates that of different groups' net income per capita;

(b) Income components are the proportions of agriculture income in net income per capita;

(c) Tax/fee ratio indicates the proportion of national tax and local charges in average income;

(d) Tax/fee ratio indicates the ratio of local charges to average income.

areas. Tax policies are preferential to the rich, which intensifies the income gap. Only if economic growth with high quality is maintained, can investment distortion be avoided, and full exploitation and utilization of human capital be realized. Only then can all of society benefit from economic growth so as to prevent poverty.

\section{New strategies of poverty reduction (2002-2015)}

The United Nations and the World Bank have publicly promised that the impoverished population of the whole world is to decrease by half by 2015. China's success or failure in poverty reduction is directly related to the realization of the world's objective. To sum it up, although China has made huge achievements in poverty reduction, the economic growth since the middle of the $1980 \mathrm{~s}$ has not led to corresponding poverty reduction; the pace of poverty reduction has slowed down and some new types of poverty have arisen. Moreover, China's official national poverty line is relatively low, far lower than the international poverty line prescribed by the World Bank, the ratio of which to per capita GDP has continuously declined. This means that the gap between this part of the impoverished population and the social collective is enlarging - their relative situation is deteriorating. Recently, China's new Premier Wen Jiabao mentioned at a press conference that China's poverty line is at a low level and he classified the issue of employment and poverty as one of the top three tough tasks. However, after the "87 anti-poverty plan" ended in 2000, the central government has not put forward new plans on poverty reduction. The Sixteenth National Congress of the Communist Party of China (CPC) points out that for 
the first two decades of the twenty-first century, the most important goal of our country is to concentrate on building a well-off society with a higher all-round standard to the benefit of well over one billion people and further to develop the economy, improve democracy, advance science and education, enrich culture, foster social harmony and upgrade the standard of living for the people. Poverty is the opposite of being well-off. Therefore, poverty reduction should be a priority in the comprehensive construction of a well-off society.

By the year 2020, the total population of China will probably reach 1.44 billion, the gross economic value will quadruple the one of 2000 , the finance income will increase enormously, China's overall national strength and international competitiveness will increase markedly, the income of residents will improve markedly, the people will lead a more affluent life, and the country and society will be more capable of further reduction of the impoverished population in cities and rural areas, and the elimination of varied phenomena of poverty. China's development objective of building a well-off society in an allround way conforms to the Millennium Development Goals (MDGs). According to UNDP's statistics the chief development index of China by the year 2001 has reached or approached the main targets of the Millennium Development Goals (see Table 5.18). If China continues its high speed of economic development, maintains stability of its society and promotes social development, not only will the goal of building a well-off society in an all-round way come true by 2015, but the Millennium Development Goals will gain great benefits from China's efforts at the same time.

China's five targets of anti-poverty in the future are: further increase average income of poor peasants by $60-65$ percent by the year 2010 , eradicate the impoverished population under the national poverty line, make great strides to eradicate the impoverished population under the international poverty line, at least reduce by two-thirds; ensure poor peasants' normal meals and basic food needs; create more opportunities for employment for the impoverished population, break barriers of systems against labor flow; enhance investment of human capital for the poor population, offer basic public services, provide conditions for learning, absorbing and applying knowledge, extend development scopes, promote the development ability of poor people radically; realize the objective of environment protection and infrastructural construction. For further background, see Table 5.19.

To this end, a new anti-poverty plan for the longer term (2003-2015) should be set down. Aiming at current problems, the anti-poverty strategic direction should be adjusted to: re-confirm the national poverty standard close to the international poverty line; identify the three types of poverty (income poverty, human poverty and knowledge poverty); pay great attention to increasing the chances of the vulnerable to participate in social activities and constructing the system of benefits; design an effective comprehensive anti-poverty strategic framework so as to keep anti-poverty policies in accordance with appropriate macroeconomic policies and regional developing policies. The suggestions in detail are as follows. 


\section{Economic and social transformation in China}

Table 5.18 To achieve millennium development goals (1990-2015)

\begin{tabular}{|c|c|c|c|c|c|}
\hline & & & 1990 & 2001 & 2015 \\
\hline Poverty & $\begin{array}{l}\text { GDP per capita } \\
\text { (PPP US \$) } 2001\end{array}$ & $\begin{array}{l}\text { China } \\
\text { East Asia and the Pacific }\end{array}$ & $\begin{array}{l}1603 \\
2346\end{array}$ & $\begin{array}{l}4020 \\
4233\end{array}$ & \\
\hline Famine & $\begin{array}{l}\text { Undernourished people } \\
(\%)\end{array}$ & $\begin{array}{l}\text { China } \\
\text { East Asia and the Pacific }\end{array}$ & $\begin{array}{l}16 \\
16\end{array}$ & $\begin{array}{r}9 \\
10\end{array}$ & 8 \\
\hline Education & $\begin{array}{l}\text { Net primary enrolment } \\
\text { ratio }(\%)\end{array}$ & $\begin{array}{l}\text { China } \\
\text { East Asia and the Pacific }\end{array}$ & $\begin{array}{l}97 \\
96\end{array}$ & $\begin{array}{l}93 \\
93\end{array}$ & 100 \\
\hline $\begin{array}{l}\text { Gender } \\
\text { equality }\end{array}$ & $\begin{array}{l}\text { Ratio of boys to girls in } \\
\text { primary and secondary } \\
\text { education }(\%)\end{array}$ & $\begin{array}{l}\text { China } \\
\text { East Asia and the Pacific }\end{array}$ & $\begin{array}{l}81 \\
84\end{array}$ & $\begin{array}{l}98 \\
89\end{array}$ & 100 \\
\hline Health & $\begin{array}{l}\text { Under-five mortality } \\
\text { rate(per } 1,000 \text { live } \\
\text { births) }\end{array}$ & $\begin{array}{l}\text { China } \\
\text { East Asia and the Pacific }\end{array}$ & $\begin{array}{l}49 \\
58\end{array}$ & $\begin{array}{l}39 \\
43\end{array}$ & 16 \\
\hline Water & $\begin{array}{l}\text { Population with } \\
\text { sustainable access to an } \\
\text { improved water source } \\
(\%)\end{array}$ & $\begin{array}{l}\text { China } \\
\text { East Asia and the Pacific }\end{array}$ & $\begin{array}{l}71 \\
71\end{array}$ & $\begin{array}{l}75 \\
76\end{array}$ & 86 \\
\hline Sanitation & $\begin{array}{l}\text { Population with access to } \\
\text { improved sanitation (\%) }\end{array}$ & $\begin{array}{l}\text { China } \\
\text { East Asia and the Pacific }\end{array}$ & $\begin{array}{l}29 \\
35\end{array}$ & $\begin{array}{l}38 \\
46\end{array}$ & 65 \\
\hline $\begin{array}{l}\text { Human } \\
\text { develop- } \\
\text { ment }\end{array}$ & $\begin{array}{l}\text { Human development } \\
\text { Index value }\end{array}$ & $\begin{array}{l}\text { China } \\
\text { East Asia and the Pacific }\end{array}$ & 0.624 & $\begin{array}{l}0.721 \\
0.722\end{array}$ & 0.85 \\
\hline
\end{tabular}

Source: UNDP, Human Development Report 2003 (Chinese edition), Beijing: Zhongguo caizheng jingji chubanshe (China Financial and Economic Publishing House), 2003.

Table 5.19 Policy evolution of employment and transference of rural labor force (1984-2003)

\begin{tabular}{|c|c|c|c|}
\hline Year & $\begin{array}{l}\text { The institution } \\
\text { publicizing the } \\
\text { document }\end{array}$ & $\begin{array}{l}\text { The publicized } \\
\text { document }\end{array}$ & Main contents of the document \\
\hline 1984 & $\begin{array}{l}\text { The Central } \\
\text { Committee of the } \\
\text { Communist Party } \\
\text { of China }\end{array}$ & Document No. 1 & $\begin{array}{l}\text { Allowing farmers to raise funds } \\
\text { independently and provide house- } \\
\text { hold register for themselves to } \\
\text { do manual works in towns and } \\
\text { cities }\end{array}$ \\
\hline 1993 & $\begin{array}{l}\text { The Third Plenary } \\
\text { Session of the } \\
\text { Fourteenth Central } \\
\text { Committee of the } \\
\text { Chinese Communist } \\
\text { Party }\end{array}$ & $\begin{array}{l}\text { The Resolution about } \\
\text { Some Issues of } \\
\text { Establishing } \\
\text { Socialistic } \\
\text { Marketing } \\
\text { Economic System }\end{array}$ & $\begin{array}{l}\text { Encouraging and steering surplus } \\
\text { rural labor force to orderly flow } \\
\text { into non-agricultural industries in } \\
\text { different regions step by step }\end{array}$ \\
\hline
\end{tabular}


Table 5.19 continued

\begin{tabular}{|c|c|c|c|}
\hline Year & $\begin{array}{l}\text { The institution } \\
\text { publicizing the } \\
\text { document }\end{array}$ & $\begin{array}{l}\text { The publicized } \\
\text { document }\end{array}$ & Main contents of the document \\
\hline 1994 & Labor Department & $\begin{array}{l}\text { Interim Regulations } \\
\text { of Rural Labor } \\
\text { Force Flowing } \\
\text { across Provinces }\end{array}$ & $\begin{array}{l}\text { Adopting management of } \\
\text { employment card or certificate }\end{array}$ \\
\hline 1995 & $\begin{array}{l}\text { The General Office } \\
\text { of Central } \\
\text { Committee }\end{array}$ & $\begin{array}{l}\text { Suggestions about } \\
\text { Strengthening } \\
\text { Management of } \\
\text { Flowing Population }\end{array}$ & $\begin{array}{l}\text { To adopt the system of unified } \\
\text { employment card of flowing } \\
\text { population and card of temporarily } \\
\text { residence }\end{array}$ \\
\hline 2001 & $\begin{array}{l}\text { The National } \\
\text { Planning } \\
\text { Committee }\end{array}$ & $\begin{array}{l}\text { Specific Programming } \\
\text { of Pivot Development } \\
\text { of Urbanization in } \\
\text { The Tenth Five-Year } \\
\text { Plan }\end{array}$ & $\begin{array}{l}\text { To reform the employment system } \\
\text { dividing up urban and rural areas } \\
\text { except in very few especially large } \\
\text { cities, to eliminate those restrictive } \\
\text { employment policies aiming at } \\
\text { farmers and population from other } \\
\text { places }\end{array}$ \\
\hline 2001 & $\begin{array}{l}\text { The Ministry of } \\
\text { Public Security }\end{array}$ & $\begin{array}{l}\text { Suggestions about } \\
\text { Promoting } \\
\text { Management } \\
\text { System of } \\
\text { Household Register } \\
\text { in Small Cities and } \\
\text { Towns }\end{array}$ & $\begin{array}{l}\text { Perpetual township household } \\
\text { register can be conducted for } \\
\text { migrant workers and their direct } \\
\text { relatives who live with them as } \\
\text { long as they have legal and fixed } \\
\text { habitation, stable jobs and sources } \\
\text { of living }\end{array}$ \\
\hline 2002 & $\begin{array}{l}\text { The Central } \\
\text { Committee of the } \\
\text { Communist Party } \\
\text { of China }\end{array}$ & Document No. 2 & $\begin{array}{l}\text { Migrant farmers should be treated } \\
\text { fairly, guided rationally, managed } \\
\text { perfectly and served excellently. } \\
\text { Unreasonable restrictions on } \\
\text { farmers entering cities and illegal } \\
\text { charges should be cleaned up }\end{array}$ \\
\hline 2003 & $\begin{array}{l}\text { The General Office } \\
\text { of the State Council }\end{array}$ & $\begin{array}{l}\text { Document No. } 1 \\
\text { The Notice of } \\
\text { Performing Good } \\
\text { Jobs of Employment } \\
\text { Management and } \\
\text { Services to Farmers } \\
\text { Who Enter Cities and } \\
\text { Do Manual Work }\end{array}$ & $\begin{array}{l}\text { Farmers should be treated fairly } \\
\text { and the guidance, service and } \\
\text { management to them should be } \\
\text { strengthened. Migrant workers' } \\
\text { legal rights and benefits should be } \\
\text { protected and they should be } \\
\text { involved in insurance of industrial } \\
\text { injuries. The right to accept } \\
\text { compulsory education of migrant } \\
\text { workers' children should be } \\
\text { guaranteed. }\end{array}$ \\
\hline
\end{tabular}

Source: B. Ren, "The Breakthrough of Policies towards Farmer Workers", Finance and Economy, 2003, issue 3/4, pp. 95-97. 
First, to adjust the national poverty line, to re-define the rural impoverished population, and to establish anti-poverty strategic steps according to the new poverty line. Box 1 lists the three schemes for estimating the rural impoverished population. Scheme A is the current national poverty line; scheme B sets the poverty line at per capita income of 1,000 Yuan; scheme C sets the line at per capita income of 1,500 Yuan. When scheme B is adopted, the estimated rural impoverished population is 100 million, of between the estimation of the World Bank and the national poverty line; when scheme $\mathrm{C}$ is adopted, the estimated rural impoverished population is 240 million, very close to the estimate made by the World Bank. We suggest that scheme B be adopted, and then transit from scheme $\mathrm{B}$ to scheme $\mathrm{C}$ gradually. According to scheme $\mathrm{B}$, the current rural impoverished population of China is about 100 million. Effective measures should be taken to decrease this part of the impoverished population in ten years, by the year of 2015. Scheme C is to be taken into consideration by 2015 and then new plans should be carried out to reduce poverty in the framework of scheme C.

Secondly, to practice macroeconomic policies and regional development policies which benefit poverty reduction. The anti-poverty experience of East Asia and China in the early 1980s shows that if policies which can effectively promote macroeconomic growth can combine with poverty reduction policies aimed at benefiting the poor, the number of the impoverished population will be greatly decreased and the burden on the impoverished population will be lightened. This includes the following:

1) Various macroeconomic policies aimed at increasing domestic demands should be connected to poverty reduction. Policies of increasing domestic demands should especially benefit peasants and the rural impoverished population first, which can reduce the gap between urban and rural areas, alleviate the living pressures of the impoverished population, promote the adjustment of the rural structure and increase the ability of peasants to develop themselves so as to ease poverty. It is suggested that policies of increasing domestic demands should adopt direct adjustment to provide basic facilities to the rural impoverished population and realize the objective of the "seven provisions," namely water provision (gap water, clean drinking-water, the necessary water supply for living and producing), electricity and electric net provision, post provision, road provision (country roads or simply roads), cable provision (broadcasting and TV), telephone provision (telephones, especially public telephones), and network provision (Internet, especially public Internet in county and village); to help farmers accelerate adjusting the agricultural structure and provide support in terms of technology, funds, information, qualified personnel and policies to adjust the agricultural structure; to help farmers develop a commodity base of agricultural products with high quality and encourage them to develop the export of green food with high added-value; to encourage large-scale agricultural enterprises to establish contractual relationships with poor farmer families and provide technical guidance and planting information to them; to help farmers and communities to establish markets for agricultural products and a transporting 
and selling system; to encourage and support farmers to store, process, transport and sell agricultural products; to increase employment opportunities for farmers and promote regional labor force flow or migration; to increase the input of rural basic education and basic public health.

2) To practice fiscal policies that are helpful in benefiting the impoverished population and increase the inputting proportion of the anti-poverty fund. New resources of revenue can be adopted by means of increasing individual income tax, imposing inheritance tax, and imposing social security tax, which can also increase the progressive degree of revenue. This will be used in poor-aid funds, bringing the proportion of poor-aid funds in GDP to 1.5 percent from the current 0.27 percent. The government will not give allowances to enterprises that suffer from loss and business (including state-owned food supplies enterprises) anymore. Instead, the government will directly give allowances to the poor. Poor-aid funds should be used to assist poverty-stricken villages or poor farmer families instead of poverty-stricken areas, the proportion of which is no less than 60 percent. The proportion of investment in the impoverished population's human capital should be increased by a large margin; it should increase to more than 20 percent from the current 2-3 percent.

3) To practice monetary policies that are helpful to benefit the broad masses of the impoverished population. To maintain macroeconomic stability, the general level of prices of agricultural products has direct bearing on farmers' incomes. On the contrary, if the macro economy is not prosperous and the price of agricultural products is continuously falling, the agricultural income of the rural impoverished population will be directly influenced. The government should help the poor to obtain loans, with discounts given by the government. The loans should be used to directly assist poverty-stricken women or families, providing necessary subsidies to poor farmer's families.

4) To get adjusted to trade policies after entering into the WTO and to aid farmer's families in producing labor-intensive agricultural products. These include vegetables, fruits, fresh flowers, tea, medicinal materials, forestry products and livestock products. The government should help farmers enhance the quality of agricultural products and increase the proportion of increment of agricultural products; the input of the government in agricultural RND should be increased by a large margin; the government should also provide market information, product information and technical services to farmers.

5) To practice regional policies that are beneficial to reducing the regional development gap. This includes establishing normative and fair systems for fiscal transfer payments, realizing the objective of basically equalizing regional average resources, enhancing the ability of poverty-stricken counties and villages to provide fundamental public services; reducing the tax and charge burden of poor farmer families; setting down national basic standards of public service and expenditure; adjusting the pivotal investment of the government in povertystricken areas; increasing investment in human capital; reducing disparity of public services in different regions. The poor-aid office of the State Council 
notifies the standing committee of NPC at least once each year of the distribution scheme of investment in aiding the poor, and the progress of investment, especially the effect index of investment such as per capita net income of poor farmers, per capita living costs and expenditures, rate of illiterate adults, enrollment rate of children, infant mortality and maternal mortality, and so on. The office will also announce the above information and the evaluation advice given by the standing committee of the NPC to the whole country. The National Auditing Office will regularly audit various expenditures of the aid-fund given by the central government, and publicize the auditing results showing irregularities. Evaluating groups made up of experts from home and abroad are established and will give their evaluation as an independent third party. Regular monitoring reports of regional poverty will also be announced by the National Statistical Bureau.

Thirdly, to adopt the developing strategies of taking employment as a priority to create more employment chances for poor people. First, various levels of governments should take creating employment as one of the most important developing objectives. Creating employment is a conscious activity. An increase in employment will not happen automatically, so the government should take creating employment as a prior objective, put into effect employment-oriented strategies and actively develop labor-intensive industries. Compared with other types of groups, the main resource of the urban or rural impoverished population or low-income population is their labor. To be engaged in formal or informal employment is their main source of obtaining income or increasing income. To increase their employment opportunities means to increase their opportunities of increasing income. Therefore, the gist of practicing employment-oriented polices is to give people the opportunity to obtain employment, including temporary, short-term and flexible informal employment. Secondly, the transfer of the agricultural labor force should be actively promoted. The most outstanding problem of development in China is that almost one-half of the labor force is concentrated in agricultural departments and the labor productivity of agricultural departments is very low. The large-scale transfer of surplus agricultural labor forces is both the core of China's economic development strategies and an important measure of China's anti-poverty strategies. Looking into the future, with the supply of agricultural exceeding demand and China's entry into WTO, the ability to increase farmers' per capita income seems likely to become smaller and smaller. Therefore, farmers' labor service income and non-agricultural income should be increased and the proportion of that in farmers' per capita net income should also be increased. In the long term, the fundamental method for solving China's rural problems is to transfer farmers and reduce the number of farmers. As a result, every region should actively encourage farmers to do manual work in cities and towns, and should improve the related laws and policies. The central government should take a firm stance against discriminating against the rural labor force by governments of different regions, and should set down in writing employment policies allowing farmer workers to compete fairly and should encourage the orderly flow and transfer of the rural labor force. 
Fourthly, to create opportunities for democratic participation and expression by the poor population. One of the fundamental reasons for the gap between urban and rural areas and for rural poverty is that the broad masses of peasants in China have neither their own representatives nor a system for expressing their opinions. According to statistics, workers and farmers account for only 18.46 percent of the total delegates to the Tenth NPC. This proportion is obviously too low because the rural population accounts for 64 percent of the total national population. If the most fundamental and major group of peasants are neglected in terms of representative structure, the immediate interests of peasants cannot be protected. As a result, the reform of the selection system of NPC delegates should be undertaken to absorb more representatives of peasants into the range of delegates. Furthermore, the impoverished population should take part in the events that can influence their life through various channels, for example, participating in the design of poverty reduction projects and performing supervision and evaluation publicly. The government should change from exclusive management and control to social governance and public management, and encourage and support privately-run departments, social groups, non-governmental organizations and international organizations to take part in China's cause of aiding the poor.

Finally, the ultimate way to reduce poverty is to invest in people and to promote the abilities of the impoverished population. First, the educational investment in the impoverished population should be increased by a large margin. Various rural education programs should be accelerated, and nine years of compulsory education should be taken as a major objective to be realized. A national educational fund should be used to directly assist the impoverished population, such as providing the tuition fees of children, the cost of books, the living subsidy of country teachers, the input fund of constructing schoolhouses and buying equipment. The government should assist poverty-stricken areas to set up semi-lodging schools, classes of young girls, and classes of minorities in primary school and secondary school. The project of educating migrants should be vigorously carried out in poverty-stricken areas in the twentyfirst century. The government should provide funds to subsidize the children of poor families who are willing to study (or after mobilization), and to achieve nine years of compulsory education or even twelve years of education, enabling them to permanently emigrate from poverty-stricken areas, giving them the same high-quality education as children in cities. The governments of major cities in the east should provide funds to local primary schools and secondary schools to make them accept "educational migrants" in poverty-stricken areas. Secondly, providing basic public health services to the impoverished population, investing in people's health and diminishing health poverty should be important contents of the anti-poverty policy. What the government should do is change from helping poverty-stricken rural areas to reestablishing a cooperative medical care system, and to establish a medical treatment assistance fund, assisting sick people and the impoverished population, giving subsidies to clinical service 


\section{Economic and social transformation in China}

expenditure, family planning expenditure and women's childbearing expenditure among the impoverished population, adopting assistance projects with low cost, high income, high social benefits and wide coverage. The government should also widely spread knowledge of public health care, meals and nutrition, enhance the ability of impoverished population to build health capital and prevent diseases, and advocate that doctors of hospitals in cites should travel to poverty-stricken areas regularly or for a short term to provide medical services to poor people. The government should provide funds to undergraduates and postgraduates of medical colleges and should encourage them to go to poor rural areas to undergo medical practice and provide medical services. Only when the government invests in people's health and education, reduces the birthrate of the population and enhances the ability of the impoverished population to support themselves, can knowledge poverty and human poverty be alleviated and income poverty be eliminated. 


\section{China's macro-economy and health ${ }^{1}$}

\section{Introduction}

In the usual discussions about the issue of health, people always consider the issue separately. They seldom observe the health issue in the macro-economic perspective. The two issues are combined and discussed in the report on Investing in Health for Economic Development by the Commission on Macroeconomics and Health $(\mathrm{CMH})$ of the World Health Organization (WHO), with Professor Jeffery D. Sachs as its Chairman. The theme of the report is the macro-economic and health issue of the world, putting forward a new thinking about development, namely, to invest in health so as to promote economic development, which provides us with a new perspective on global economic development and health issues.

Many analyses and suggestions in the report are very valuable to developing countries, especially to the poorest nations. A large number of research results related to health and development are listed in the report, and the main agendas of the economic development in health as well. The report suggests in particular that each country establish its own committee of national macro-economy and health, evaluate the national health areas that take precedence, broaden the coverage of the basic health services, and reinforce cooperation with other departments to guarantee that health development is identical to the overall macro-economic policies. The report also discusses how to reach the goal of reducing poverty and improving people's health standards by peaceful methods, by means of applying the most advanced scientific technologies and tremendous wealth of the rich nations, combined with joint efforts of the whole world. It provides important knowledge and enlightened of policies for promoting global health and development.

China is a country that has one of the world's fastest economic growths. The achievement of China's economic growth has become the focus of world attention. However, there are few discussions about the relationship between health development and macro-economy at home. What is the relationship between economic growth and health development in China? What characteristics does the relationship have in different periods? In the area of health which is related to China's macro-economy, what are the main problems China is confronted 


\section{4}

with currently? What objectives will future health developments achieve? How can China promote health development through effective public policies and then promote the whole economy? These are the issues that concern us.

Through comparisons made internationally, we have found that compared with the indicator of income per capita, the indicators of China's population and health were on a relatively high level after the foundation of the People's Republic of China, exceeding the average level of low medium income countries and approaching the average level of high medium income countries. However, as shown by historical records, the growth rate of China's health indicators has been obviously left behind by the growth rate of the indicator of income per capita. What's more, due to the diversity and complexity of China's national conditions, the fact of "one China, two systems" and "one China, four worlds" exists, that is to say, a gap exists between urban and rural areas and a gap also exists between different regions, which is a continuing problem. ${ }^{2}$ Similar problems also appear in healthcare, which is reflected in the difference in the disease model between urban inhabitants and rural inhabitants, and the gap in health services and levels of health between regions. In addition, China is also confronted by the great challenge of new global health problems, such as AIDS in the context of globalization. These problems have had great impacts on China's macro-economy and long-term economic growth. The Sixteenth National Congress of the Communist Party of China that was held recently puts forward the development objective of an all-round construction of a well-off society, the core of which lies in the development of people and the improvement of people's welfare. Health is the core element of people's welfare and should be an important component of the well-off society. The health objective plays an important role in the millennium objective put forward by the Summit Forum of the United Nations. Due to its population, which takes up one-fifth of the world's population, China should make important contributions to the realization of the millennium objective. If the view that "people's health and welfare should take precedence" is established, the government's public policies should work towards people's health, macro-economic policies should be beneficial to the improvement of people's health level and a new mode of governance should be realized in the health area.

\section{Historical records of China's economic growth and health}

It is necessary here for us to analyze the relationship between China's economic growth and its population and health according to the historical records. Table 6.1 demonstrates the main indexes of China's human capital in 1950, 1982 and 2000 , including the average years of education for people above 15 years old, which reflects the education level; the population's average life expectancy and infant mortality rate, which reflects the health level; the index of human development, which reflects people's quality of life and social equality. Of these data, those for 1950 are estimated by the author; those for 1982 and 2000 are calculated according to the data of the fourth and fifth national census. Table 6.2 
calculates the average growth rate of indexes of China's main economies and human capital in the period from 1950 to 1980 and the period from 1980 to 2000 respectively. The data of Table 6.1 and Table 6.2 show the following.

First, the level of not only income per capita but also human capital is rather low in the early stage of China's industrialization and modernization. It is estimated by Maddison that per capita GNP of China was US \$537, according to the price of the dollar in 1990, analogous to one-quarter of the per capita GNP (US \$2268) of the whole world, lower than the per capita GNP (US \$609) of India, and was one of the poorest countries in the world. ${ }^{3}$ In 1950, the average years of education of people above 15 years old was only 1.0 year (according to Maddison's estimate, whose methods are different from the author's, it should be 1.6 years in 1952); the population's average life expectancy was about 35 years; the infant mortality rate was $200 \%$; and the human development index (HDI) was 0.159 . This shows that China at that time was one of the countries whose levels of human development were the lowest in the world, which is the

Table 6.1 Main indicators of human capital in China (1950-2000)

\begin{tabular}{lccc}
\hline Indicator & 1950 & 1982 & 2000 \\
\hline Average educational years & $1.0(\mathrm{a})$ & $4.6(\mathrm{~d})$ & $7.1(\mathrm{~d})$ \\
Average life expectancy(year) & $35(\mathrm{~b})$ & $67.77(\mathrm{~d})$ & $71.4(\mathrm{~d})$ \\
Infant mortality rate $\%$ ) & $200(\mathrm{~b})$ & $37.61(\mathrm{~d})$ & $28.38(\mathrm{~d})$ \\
Human development index & 0.159 (c) & $0.553(\mathrm{e})$ & $0.724(\mathrm{e})$ \\
\hline
\end{tabular}

Sources:

(a) Estimated by the author in A. Hu, "Goujian zhongguo da zhanlue: 'fumin qiangguo' de hongda mubiao" (Constructing China's Grand Strategy of "Enriching the People and Strengthening the Country"), China Studies Reports, November 12, 2002-11-12.

(b) Guojia tongjiju (National Bureau of Statistics of China), Xinzhongguo wushinian tongji ziliao huibian (Comprehensive Statistical Data and Materials on 50 Years of New China), Zhongguo tongji chubanshe (China Statistics Press), 1999.

(c) N. Crafts, "Globalization and Growth in the Twentieth Century," IMF Working Paper, 2000, $\mathrm{WP} / 00 / 4$.

(d) Guojia tongjiju (National Bureau of Statistics of China), Zhongguo tongji zhaiyao 2002 (China Statistical Abstract 2002), Beijing: Zhongguo tongji chubanshe (China Statistics Press), 2002, p.34.

(e) UNDP, available at http://www.undp.org/hdr2002/indicator (accessed December 10, 2002).

Table 6.2 Average annual growth rate of main economic and human resource indicators in China (1950-2000) (\%)

\begin{tabular}{lcc}
\hline Indicator & $1950-1980$ & $1980-2000$ \\
\hline GDP per capita & 4.0 & 8.3 \\
Consuming level & 3.1 & 7.1 \\
Average educational years & 5.1 & $2.3^{*}$ \\
Average life expectancy & 2.1 & $0.3^{*}$ \\
Infant mortality rate & -5.1 & $-1.6^{*}$ \\
Human development index & 4.2 & 1.4 \\
\hline
\end{tabular}

Source: Same as table 6.1 


\section{6}

basis of human capital at the starting point of China's industrialization and modernization. This is also the bottleneck restricting the development of human capital and affecting China's industrialization and modernization.

Secondly, in the period from 1950 to 1980 , China's growth rate of per capita income was relatively low, but the growth rate of the main indices of human capital was relatively high. In this period, the average growth rate of per capita GDP per year was 4.0 percent at constant prices; the average growth rate of the whole nation's consuming level per year was 3 percent; the average growth rate of years of education of people above 15 years old was 5.1 percent; the average growth rate of the population's life expectancy was 2.1 percent; the average reduction rate of infant mortality was 5.1 percent; and the average growth rate of HDI was 4.2 percent. According to Maddison's estimate, China's per capita GDP in 1978 was US $\$ 979$, still analogous to that of one-quarter of the whole world (US \$4383), and a bit higher than that of India (US \$972). By 1982, the average years of education of people above 15 years old had been raised to 4.6 years, the population's life expectancy had been raised to 68 years, the infant mortality rate had been reduced to 37.6 percent, and HDI had been raised to $0.553 .{ }^{4}$

Since the People's Republic of China was founded, China has rapidly finished the first health revolution under the condition of low income, namely, China has put the emphasis on public services such as the prevention, control and elimination of infectious diseases, and ensured the wide availability of basic medicine and basic medical services, which enables the public health condition to be improved greatly. At the same time, China has established a national health care system in both urban and rural areas. The elementary service system of health care has been put into practice in rural areas in particular. Consequently, many basic health and health indices have improved, and even exceed the level of economic development. Under the guidance of this strategy, people can obtain good health without paying high medical fees, which improves the level of health of China's population, especially of the poor people. Compared with other developing countries, on an equal basis of income, China's health index is obviously on a higher level, which reflects the fact that China's level of health development is higher than that of its economic development, that is to say, the level of the material standard of life of the Chinese people is higher than the level of China's per capita GDP. This shows that the human capital was greatly improved when China launched its reform and began to be open to the outside world. To some extent, this has also laid foundation of human capital for China's economic takeoff.

Thirdly, the growth rate of China's per capita income in the period from 1980 to 2000 was relatively high, but the growth rate of indices of the main human capital were relatively low. During this period, the average growth rate of per capita GDP was 8.3 percent at constant prices, twice as much as that from 1950 to 1980; the average growth rate of national consuming level was 7.1 percent, 2.3 times as much as that from 1950 to 1980; the average growth rate of the population's years of education was 2.3 percent, less than half of that from 1950 to 1980; the average growth rate of the population's life 
expectancy was 0.3 percent, greatly lower than the level from 1950 to 1980; the average rate of reduction of the infant mortality rate was 1.6 percent, greatly lower than the level from 1950 to 1980; the average growth rate of the index of human development was 1.4 percent, also greatly lower than the level from 1950 to 1980 . By 2000 the years of education of people above 15 years old had gone up to 7.1 years, higher than that of the average level of the whole world (6.5); life expectancy had gone up to 71.4, coming up to the average level of medium countries; infant mortality rate had been reduced to 28.4 per thousand; the mortality rate of children under 5 years old was 37 per thousand, lower than the average level of low-medium income countries, but higher than the average level of high-medium income countries; HDI had gone up to 0.724 , which is on the level of low-medium human development countries.

In this period, either per capita GDP or the growth rate of people's consuming level exceeded the growth rate of human capital, much higher than that of the health index in particular. Observed from a historical point of view, the improving degree and speed of China's population health index is obviously lower than that before the reform. Although China has realized the objective of economic growth ahead of time, namely, to quadruple the total GDP and per capita GDP by 2000 , the important social development objective that everyone will enjoy elementary health care was not put into effect as scheduled. We can regard the relationship between China's economic growth and health from 1950 to 1980 as a "combination" type, while that from 1980 to 2000 was a "separation" type. This shows that economic growth is an important condition for improving the population's health, but it will not realize the objective automatically, naturally and spontaneously unless the economic development policies that are beneficial to the poor population and the social development policies that are beneficial to social equality can be adopted so that people can not only share the important achievements of economic growth, but also enhance the stored quantity of one's own human capital and improve their level of health. China's development is a very complicated phenomenon and contains many phenomena beyond people's understanding. In terms of international comparisons, China's population health index is at a relatively high level, exceeding the average level of low-medium income countries and approaching the average level of high-medium income countries. The level of social development is higher than that of economic development, which is especially obvious in the period from 1950 to 1980 . However, in terms of the historical records, the growth rate of China's population health index is not only very low, but it also lags behind compared with the per capita income index.

\section{Challenges to China's health}

Although the main health index of China's population has come up to the countries of medium income in the world, China is a developing country with a large population, vast territory and unbalanced development of different regions. Further, the rural population takes up a dominant proportion. The basic national 
conditions make the health issue a main problem all along the course of speeding up economic development, as seen in the following.

\section{People are facing the "double-burden of disease"}

A great disparity of disease exists between urban inhabitants and rural inhabitants. With the first health revolution in the twentieth century, the transformation of the population resulted in the transformation of the disease model. ${ }^{5}$ In this health revolution, great progress in medical techniques has been achieved, methods of inoculation and vaccines have been invented, and antibiotics have been widely used to cure contagious diseases. With people's income increasing, education spreading and nutrition improving, the contagious diseases that seriously threatened people's lives, such as malaria and plague, have been eliminated. Thus, the level of people's health has improved and life expectancy has obviously been prolonged. But the prolonged life expectancy and major changes in people's lifestyles have led to the prevalence of cancers and other chronic diseases. Some developing countries also experienced such transformations after World War II, following developed countries. However, because the time for transformation is short and the speed of transformation is fast, the transformation speeds of different groups of people are very different. Therefore, an incomplete transformation of the disease model appears, and people are faced with the "double-burden of disease." The case is the same with China, the obvious manifestation being in the different models of disease between urban inhabitants and rural inhabitants. Most of the contagious diseases and diseases related to too close confinement and poor nutrition have been controlled. But new types of contagious diseases such as HIV/AIDS and so on, more and more chronic diseases such as cancer, cardiovascular system diseases, and diabetes have become the main elements threatening people's health. Psychological diseases have also become a problem that we cannot neglect. In the vast rural areas, especially those areas with poor economic conditions, due to adverse ecological circumstances and poor health conditions, some contagious and regional diseases have not been fundamentally controlled. The incidence of diseases of women and children is still very high in some regions (see Table 6.3, Table 6.4, Figure 6.1, and Figure 6.2). These diseases will cause serious loss to human capital and most of them can be prevented and cured through cheap and effective methods. The appearance of the gap between health conditions in urban areas and in rural areas is related to the rural reform of the collective economy, the disintegration of cooperative medical treatment and the slow increase of peasants' income growth. The most fundamental reason is that the binary structure of China's urban and rural areas leads to the great disparity between urban inhabitants and rural inhabitants when enjoying public services, and so on. The transformation of China's disease model is incomplete, for the urban population and most of the rural population are at different stages of the transformation of the disease model, which makes China confront the "double-burden of disease." This is a difficult problem and a major challenge facing China's health system. 
Table 6.3 Health expenditure per capita in urban and rural areas (1996-2000)

\begin{tabular}{lccc}
\hline Indicator & 1996 & 2001 & $\begin{array}{l}\text { 1996-2002 } \\
\text { annual growth rate (\%) }\end{array}$ \\
\hline Per capita health expenditure (Yuan) & & \\
Urban Residents & 143.3 & 343.3 & 19.1 \\
Rural Residents & 58.26 & 96.61 & 10.6 \\
Total expenditure on health (0.1 billion Yuan) & & \\
Urban residents & 534.6 & 1650 & 25.3 \\
Rural residents & 495.7 & 769 & 9.2 \\
Total & 1030.3 & 2419 & 18.6 \\
Percentage to GDP (\%) & 1.52 & 2.52 & \\
\hline
\end{tabular}

Source: Guojia tongjiju, Zhongguo tongji zhaiyao 2002, pp 14, 35, 93, 98.

Table 6.4 Inpatient rate by disease in survey areas (1998)

\begin{tabular}{|c|c|c|c|c|c|}
\hline Disease & $\begin{array}{l}\text { Urban } \\
\text { inpatient } \\
\text { rate (\%o) }\end{array}$ & $\begin{array}{l}\text { Component } \\
(\%)\end{array}$ & Disease & $\begin{array}{l}\text { Rural } \\
\text { inpatient } \\
\text { rate (\%o) }\end{array}$ & $\begin{array}{l}\text { Component } \\
(\%)\end{array}$ \\
\hline \multirow{2}{*}{$\begin{array}{l}\text { Cerebrovascular } \\
\text { disease }\end{array}$} & \multirow[t]{2}{*}{4.20} & \multirow[t]{2}{*}{8.69} & Gastritis & 1.73 & 5.57 \\
\hline & & & Pneumonia & 1.45 & 4.67 \\
\hline \multirow{2}{*}{$\begin{array}{l}\text { Gall-stone and } \\
\text { cholecystitis }\end{array}$} & \multirow[t]{2}{*}{2.29} & \multirow{2}{*}{4.75} & Fracture & 1.23 & 3.95 \\
\hline & & & \multirow{2}{*}{$\begin{array}{l}\text { Gall-stone and } \\
\text { cholecystitis }\end{array}$} & \multirow{2}{*}{1.08} & \multirow{2}{*}{3.49} \\
\hline Hypertension & 1.81 & 3.76 & & & \\
\hline Fracture & 1.52 & 3.15 & Appendicitis & 1.07 & 3.45 \\
\hline Pneumonia & 1.47 & 3.04 & \multirow{2}{*}{$\begin{array}{l}\text { Cerebrovascular } \\
\text { disease }\end{array}$} & \multirow[t]{2}{*}{0.85} & \multirow[t]{2}{*}{2.75} \\
\hline Bronchitis & 1.45 & 3.00 & & & \\
\hline Diabetes & 1.21 & 2.51 & Nasopharyngitis & 0.82 & 2.65 \\
\hline Appendicitis & 1.10 & 2.28 & Bronchitis & 0.81 & 2.61 \\
\hline Gastritis & 1.04 & 2.16 & Bronchitis & 0.66 & 2.13 \\
\hline Emphysema & 0.75 & 1.56 & Quinsy & 0.53 & 1.70 \\
\hline Cardiopathy & 0.73 & 1.52 & Enteron abscess & 0.52 & 1.68 \\
\hline Nasopharyngitis & 0.68 & 1.40 & Influenza & 0.50 & 1.62 \\
\hline \multirow{2}{*}{$\begin{array}{l}\text { Diapophysis } \\
\text { disease }\end{array}$} & \multirow[t]{2}{*}{0.68} & \multirow[t]{2}{*}{1.40} & Hurt & 0.50 & 1.60 \\
\hline & & & Arthritis & 0.47 & 1.52 \\
\hline Enteron abscess & 0.66 & 1.37 & & & \\
\hline
\end{tabular}

Source: Analysis Report of the Second National Health Services Survey 1998.

Notes: Cerebrovascular disease, coronary heart disease, and high blood pressure are the top three diseases for inpatients in urban areas; dysentery, hepatitis, tuberculosis, and flu are the top reasons for inpatients in rural areas; while in the poor rural areas, infection, transmission disease, and malnutrition are the main diseases for inpatients.

\section{Great gaps in health development among different regions}

Identical to the gap in economic development, gaps in health development also exist in different areas of China. Great differences exist if some indices of the health levels of different groups, basic health conditions, the demand and provision of health services in different provinces (see Table 6.5). This gap is further 


\section{0}

Economic and social transformation in China

demonstrated in terms of eastern, middle and western regions (see Table 6.6). These show that on the one hand, the gap in economic development leads to the gap in the expenditure on health care and in the coverage of health services, which further results in the gap in people's health conditions. On the other hand, the poor health condition of people in some regions has become an important element that restricts economic development and hinders such regions

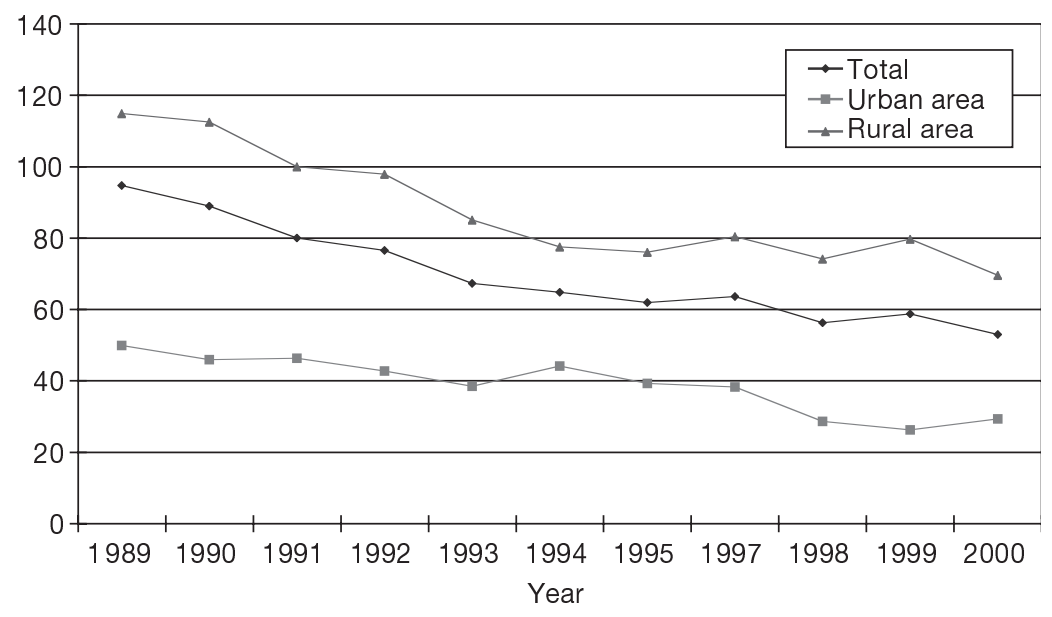

Figure 6.1 Pregnant mortality rate trend (1989-2000) (1/0.1 million)

Source: Weishengbu (Ministry of Health), Zhongguo weisheng tongji zhaiyao (China Health Statistics Highlights), 2001.

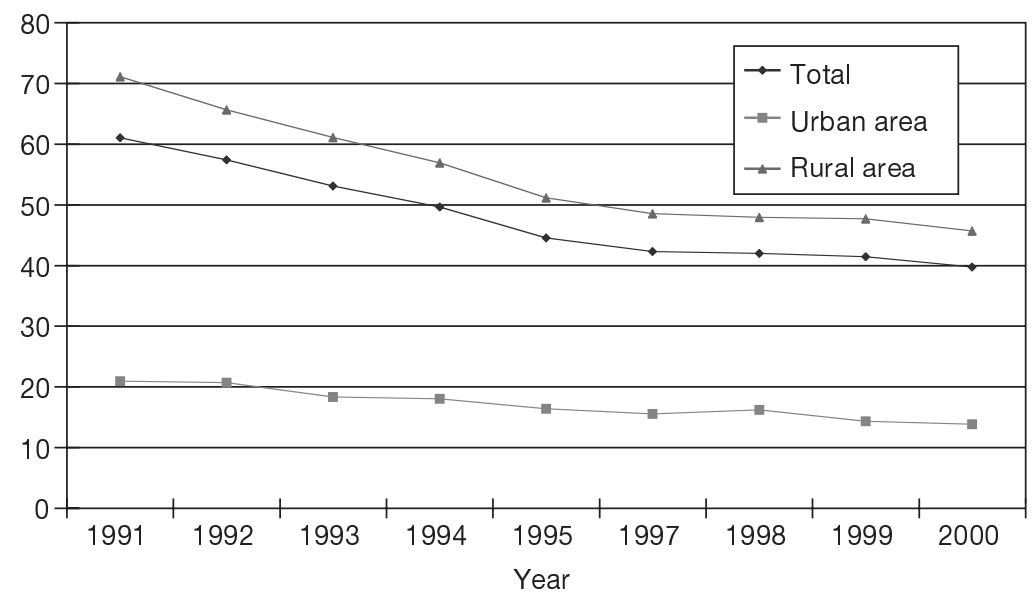

Figure 6.2 Trend of mortality rate for children under 5 years old (1991-2000) (\%)

Source: Weishengbu (Ministry of Health), Zhongguo weisheng tongji zhaiyao (China Health Statistics Highlights), 2001. 
from escaping the trap of poverty, and present an obstacle to reducing the gaps in economic development between different regions. Moreover, the government's ability to strengthen regional transferred payments and support the backward areas is not enough. The government is unable to redistribute the limited public health expenditure throughout the country, which does not accord with the principle of fairness. The principle of fairness requires that different groups of people can equally enjoy basic health services, that is to say, regardless of one's economic condition, nationality and living area, health resources should be distributed according to his or her needs, not on one's ability to pay, so that the primary function of health resources to serve the people can be brought into play.

\section{New problem: the impact of global threats of AIDS on China}

In recent years, the prevalence of AIDS has become very severe, presenting a tendency towards rapid increase. According to The Report of Global AIDS in 2002 announced by WHO and UN's Programming Office of AIDS on November 26,2002 , there is a danger that China will have a sharp increase in the number of AIDS patients. Currently there are about 1 million AIDS patients in China. The report warns that if China does not take some effective measures, the number of people infected with HIV will increase to 10 million by 2010, that is to say, the number will have increased nine times during that period of time. Based on what the Rand Company of America has estimated, the number of AIDS patients in 2002 is 0.6 million to 1.3 million, and if it increases at the rate of 20 percent to 30 percent, the number will be 11 million to 80 million by 2015. AIDS and contagious diseases will have a negative impact on China's sustained economic growth.

In researching how serious a disease is, there is an index based on whether or not it attacks the young and strong people of the labor force. It is currently reported that 93.9 percent of the people who have been infected by HIV are 15-49 years old, in other words within the rich manpower resource that is one of the greatest advantages of our nation for developing the economy. The Rand Company has estimated that the percentage of the negative impact on China's economic growth rate produced by various contagious diseases in the future will be between 1.8 percent to 2.25 percent. $^{6}$

\section{Various health problems affecting China's macro-economy and long-term economic growth}

The factual foundation of health and development and the channels for diseases to affect economic development can be found in the CMH report. As far as China is concerned, we think that the success of the first health revolution, the control of basic contagious diseases and the improvement in nutrition have greatly improved the whole nation's physique and health condition, which is one of the factors for the development of China's strong economy since the 


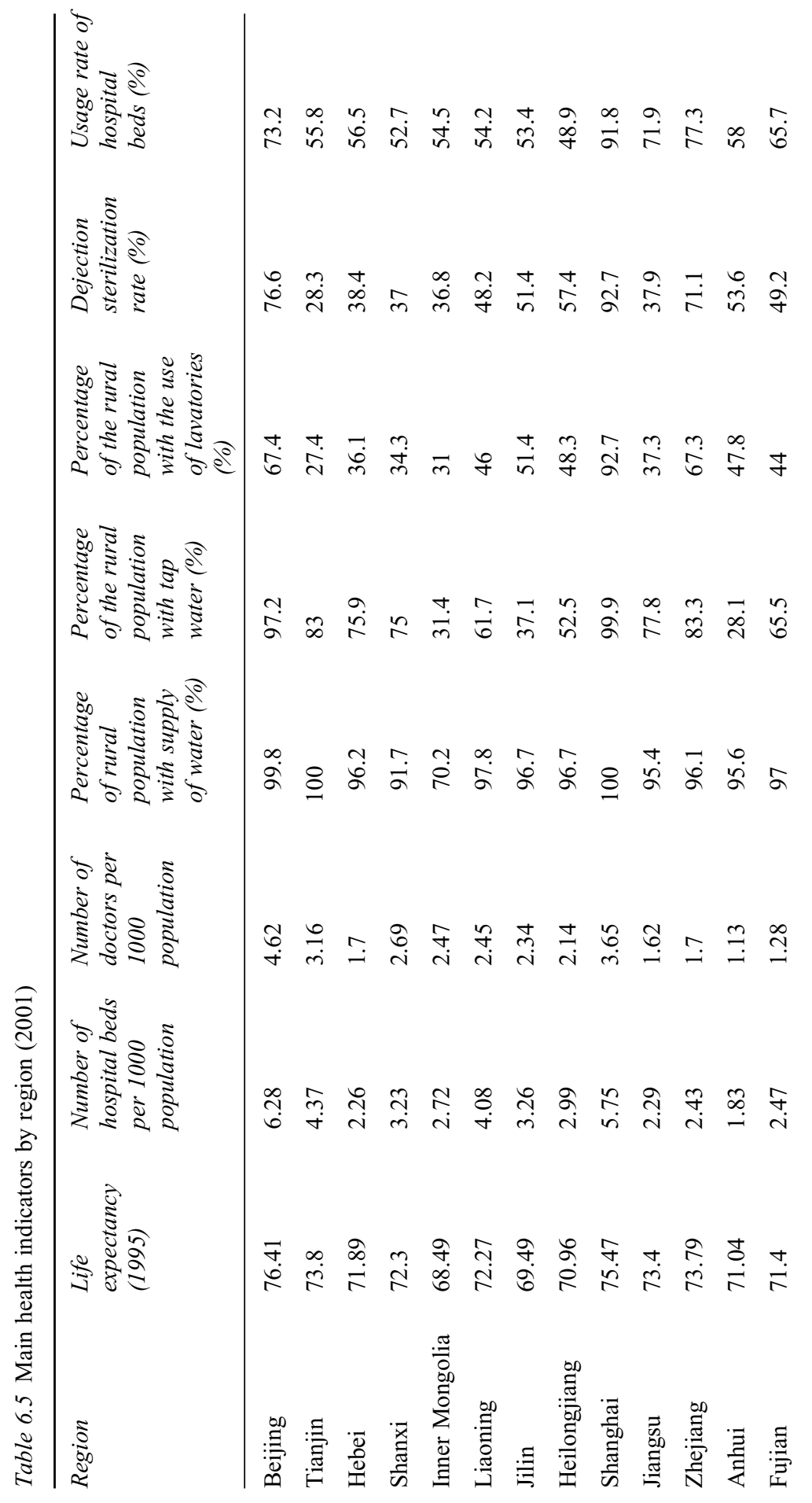




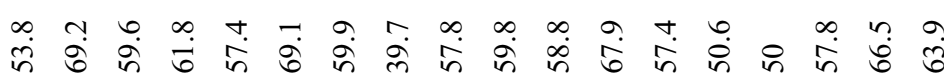

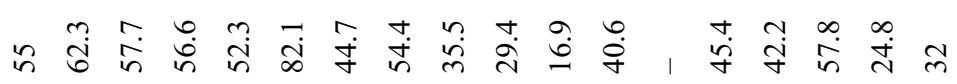

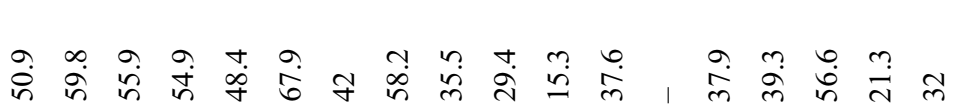

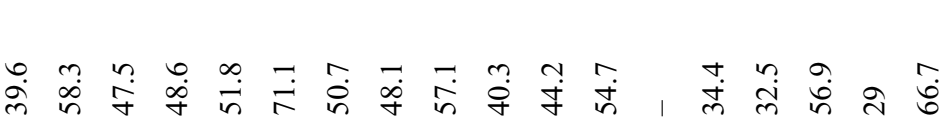

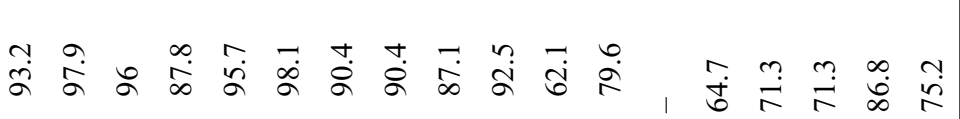

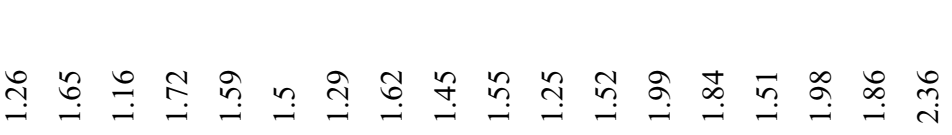

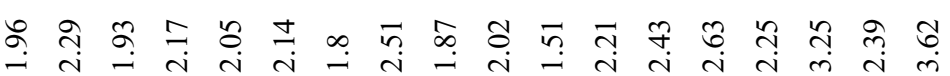

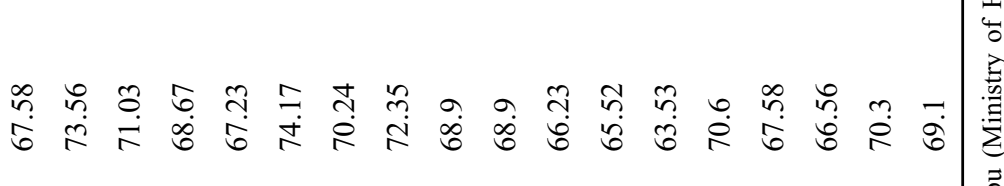

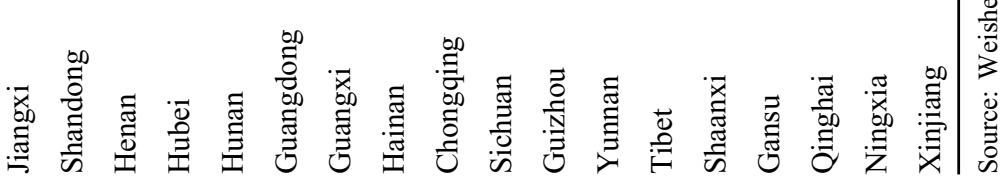


Table 6.6 Care service availability index by region (1999)

\begin{tabular}{|c|c|c|c|}
\hline $\begin{array}{l}\text { Health care service } \\
\text { availability Index }\end{array}$ & Eastern area & Central area & Western area \\
\hline High level & $\begin{array}{l}\text { Beijing }(0.06) \\
\text { Shanghai }(0.12) \\
\text { Tianjin }(0.22)\end{array}$ & & \\
\hline $\begin{array}{l}\text { High middle level } \\
(0.50>C \text { CSAI } \geq 0.25)\end{array}$ & $\begin{array}{l}\text { Hebei }(0.27) \\
\text { Liaoning }(0.27) \\
\text { Fujian }(0.47) \\
\text { Jiangsu }(0.47)\end{array}$ & $\begin{array}{l}\text { Jilin }(0.36) \\
\text { Heilongjiang }(0.38) \\
\text { Shaanxi }(0.43)\end{array}$ & $\begin{array}{l}\text { Qinghai }(0.37) \\
\text { Xinjiang }(0.39) \\
\text { Inner Mongolia }(0.43) \\
\text { Ningxia }(0.46) \\
\text { Yunnan }(0.46)\end{array}$ \\
\hline $\begin{array}{l}\text { Low middle level } \\
(0.75>\text { CSAI } \geq 0.50)\end{array}$ & $\begin{array}{l}\text { Shandong }(0.50) \\
\text { Guangdong }(0.50) \\
\text { Hainan }(0.56)\end{array}$ & $\begin{array}{l}\text { Jiangxi }(0.50) \\
\text { Henna }(0.51) \\
\text { Hubei }(0.52) \\
\text { Hunan }(0.53) \\
\text { Anhui }(0.54)\end{array}$ & $\begin{array}{l}\text { Guangxi }(0.50) \\
\text { Gansu }(0.52) \\
\text { Shanxi }(0.53) \\
\text { Sichuan }(0.60) \\
\text { Guizhou }(0.72)\end{array}$ \\
\hline $\begin{array}{l}\text { Low level } \\
(\mathrm{CSAI} \geq 0.75)\end{array}$ & Zhejiang (0.76) & & Xizang (0.91) \\
\hline
\end{tabular}

Source: UNDP, Human Development Report 2002 (Chinese edition), Beijing: Zhongguo caizheng jingji chubanshe (China Financial and Economic Publishing House), 2002.

Notes: CSAI is calculated by number of hospital beds per 1000 people, number of doctors per 1000 people, number of nurses per 1000 people, proportion of population with access to hospital service, which can reflect the level of health care service in a region.

1980s. Some scholars have estimated that the average life expectancy of China's population has increased to 69 from 35 during the period from 1950 to 1982 , thanks to the economic value that 2473 billion Yuan has created, about 77.3 billion Yuan per year, corresponding to 22 percent of GNP. ${ }^{7}$ However, in the current situation, some problems appearing in the health area have affected the development of the macro-economy, including in the rural areas where preventable diseases have caused losses to human capital. The gap in health development between areas harms the ability of poverty-stricken areas to get rid of poverty and limits any reduction in the gap of economic development between areas. Various contagious diseases, such as AIDS, are likely to produce gigantic burdens, and to affect the regular operation of trade and investment.

The economic costs of various diseases can be calculated by the direct treatment cost, the opportunity cost caused by the absence of working and studying, and the indirect cost of serving the patient. The method of calculating the Disabled Adjusted Life Year (put forward by WHO) can also be adopted to measure the losses. For example, the method of calculating the economic costs caused by DALY has been used to measure the economic burden caused by diseases in the $\mathrm{CMH}$ report. Here, the vision of the health GDP accounting system is advanced as another method by estimating the losses caused by diseases, and as a revision to the GNP account. The traditional account of GNP 
is calculated additively, such as the sum total of production, namely, to add up the production value of the first, the second and the third industry; the sum total of expenditure, namely, to add up investment, consuming and net export, and so on; the sum total of elements, namely, to add up salary and rent, and so on. In fact this method has a very obvious defect - the loss of national welfare is not taken into consideration, especially the human capital loss and economic cost caused by illness and deformity. Therefore, the World Bank has put forward a system of green national accounts to measure national wealth, namely, the real rate of national savings is calculated by the result of various losses of natural assets subtracted from the national net welfare. ${ }^{8}$ Can we now imagine a health GDP accounting system? Namely, the human capital loss and economic cost caused by illness and deformity are subtracted from the nominal GDP. Regardless of the calculation method, the purpose is to make people realize that diseases, deformity and death cause losses to the national welfare, while the maximization of the national welfare and the minimization of various losses is the purpose of development.

\section{China's health development objectives in the next twenty years}

What is China's development objective for health in the next twenty years? It is to enable more than 1 billion people to lead a healthier and longer life with more benefits and higher quality. The specific objectives are as follows:

First, the objective of access to health services: to ensure that everybody enjoys elementary health care, and then to unceasingly improve the quality of basic public health services. In all areas, especially in the economically backward rural areas, people need to actively promote the popularization of elementary health care so as to make elementary measures of health care available to everyone. The lowest standard that everyone should enjoy health care was formulated in 2000 by the Ministry of Health, improving the standard of health expenditure by the government, the standard of health service institutions, the standard of the coverage of medical insurance, the standard of basic health care services such as access to safe water and lavatories, prevention and immunity, and basic health indices of people (see Table 6.7). Parts of areas that don't reach the targets should further improve these standards. Based on realizing universal coverage of basic health services, the quality and standard of service should be continuously improved to fulfill the target of using the minimum input to realize the maximum output, namely, to realize the unification of the principle of fairness and the principle of efficiency. "Efficiency" refers to whether or not one can achieve the same health effect with minimum health resources, or whether or not one can produce greater health effects with the same resource. Health services of high efficiency are helpful in reducing input and saving health resources. This requires pursuing research in selected areas of epidemiology, establishing an outcome-oriented health system, and adopting measures for maximum cost benefit aimed at different problems. ${ }^{9}$ 
Table 6.7 Minimum requirements for the "Everybody enjoys health services in 2000" project (by county)

\begin{tabular}{|c|c|c|c|c|}
\hline \multirow[t]{2}{*}{ Elementary health indicators } & \multicolumn{4}{|c|}{ Minimum requirements } \\
\hline & Poor & $\begin{array}{l}\text { Not } \\
\text { poor }\end{array}$ & Rich & Richer \\
\hline $\begin{array}{l}1 \text { Take basic medical care as county or town } \\
\text { government's goal and economic growth } \\
\text { programming }(\%)\end{array}$ & 100 & 100 & 100 & 100 \\
\hline $\begin{array}{l}2 \text { Proportion of county or town government's } \\
\text { fund to each's expenditure }(\%)\end{array}$ & 8 & 8 & 8 & 8 \\
\hline $\begin{array}{l}3 \text { Popularization rate of health education (\%) } \\
\text { (ratio of accessed people to total population) }\end{array}$ & 50 & 65 & 80 & 90 \\
\hline $\begin{array}{l}4 \text { A Coverage rate of village medical rooms in } \\
\text { administrating village (\%) }\end{array}$ & 90 & 95 & 100 & 100 \\
\hline $\begin{array}{l}\text { B Proportion of village medical room ranked A } \\
\text { to all }(\%)\end{array}$ & 30 & 50 & 70 & 90 \\
\hline 5 Coverage rate of collect-money medical care $(\%)$ & 50 & 50 & 60 & 60 \\
\hline $\begin{array}{l}6 \text { Popularization rate of "safe and clean water" (\%) } \\
\text { (ratio of accessed people to total population) }\end{array}$ & 60 & 70 & 80 & 90 \\
\hline 7 Coverage rate of “clean lavatory” (\%) & 35 & 45 & 70 & 80 \\
\hline 8 Up-to-grade rate of food $(\%)$ & 80 & 80 & 85 & 85 \\
\hline $\begin{array}{l}9 \text { Reducing rate of infant mortality every five } \\
\text { years }(\%)\end{array}$ & 20 & 15 & 8 & 5 \\
\hline $\begin{array}{l}10 \text { Reducing rate of pregnant women mortality every } \\
\text { five years }(\%)\end{array}$ & 30 & 25 & 20 & 15 \\
\hline 11 Inoculation of one of children's "four bacteria" (\%) & 85 & 85 & 90 & 95 \\
\hline $\begin{array}{l}12 \text { Reducing rate of morbidity of legally reported } \\
\text { infectious diseases every five years }(\%)\end{array}$ & 15 & 15 & 10 & 10 \\
\hline
\end{tabular}

Source: Weishengbu, Weisheng tongji zhaiyao 2001.

Secondly, the specific objective of population and health: to realize the promise made by the UN's Millennium Declaration on population and health. The Millennium Summit Forum of the United Nations adopted the UN's Millennium Declaration and decided on objectives aimed at combining the efforts of all nations to eliminate the basic poverty of human beings in education and health, and to realize the progress of human development. The quantified and controllable objectives include: in 2020, infant mortality is to decrease by half of that in 2000; in 2015, mortality of pregnant women is to decrease by 15 percent (in China, 65 women in parturition died out of 100,000 women in the period 1990-1998); by 2015, the general method of contraception that is safe and efficient will have been acquired (in China, the rate of acquiring safe 
contraception was 85 percent in the period 1990-1998, while the world rate was 45 percent); by 2005 , the number of people who want to limit giving birth to children but don't want to use birth control will decrease by half; by 2015, the percentage of women who can enjoy good care from skilled doctors and nurses in various child-bearing situations will increase to 90 percent; and the impoverished population will decrease by two-thirds. The millennium development objective is a significant political promise to the development of human beings made by political leaders of each nation in the world. China as a country with the largest population in the world plays a very important role in realizing the millennium development objective. The improvement of the health indices of China's population will make great contributions to world health.

Thirdly, controlling the dissemination of AIDS has become an extremely urgent task to deal with. Timely control measures should be taken to prevent the rapid increase of infection. According to China's Medium-Long-Term Plan to Prevent and Control AIDS printed and distributed by the State Council, the number of adults of our nation who have been infected with the AIDS virus is to be controlled at a low level globally (less than $1,500,000$ ) by 2010 . Therefore, education and dissemination of knowledge about how to prevent and treat AIDS and venereal disease should be spread extensively among the people. By 2010, the percentage of people who know how to prevent AIDS and venereal disease in relatively big cities will be higher than 95 percent; in medium and small cities higher than 85 percent; in county towns higher than 70 percent; in rural areas higher than 60 percent. The rate of treating AIDS patients and the coverage of antiretroviral maintenance regimens for HIV infection should be higher than 80 percent.

Fourthly, to promote health education, to realize sports practice among the whole nation and to establish a medical health care system of high efficiency, flexibility and availability. The report of the Sixteenth National Congress of the Communist Party of China put forward the objective of forming a good system of modern national education, a system of technology and cultural innovation and a system of national sports practice and medical care. Knowledge about health and healthy modes of behavior have become important factors affecting people's health. For this reason, health education and dissemination should be popularized, a specialized curriculum about health knowledge should be given and propagation of health should be strengthened in such media as radio, television and newspapers. In our opinion, the core of the system of medical treatment lies in meeting people's needs for health care. Its characteristics should be high efficiency, flexibility and availability to patients. The report of committee members mentions that to strengthen basic intervention is not so difficult in terms of technology. Most of the services can be provided by health centers, small-scale organizations of medical treatment (or small health centers) or the extended service of these organizations, which will be called a "close-to-client system." Such measures can cover the whole nation. In addition, various full-time or part-time organizations, both profit-seeking and non-profit-seeking, should be developed at various levels to satisfy people's needs for medical treatment and health care. 


\section{Establishing the well-off society in an all-round way is to invest in people's health}

The report of the Sixteenth National Congress of the Communist Party of China put it forward clearly that the main task of China's development in the nexty twenty years is to establish a well-off society at a higher level that can be beneficial to more than 1 billion Chinese people. This is the development objective of modernization oriented towards people. The purpose of this development strategy is to satisfy people's day-to-day increasing needs, both material and immaterial. Economic growth is the means of development, the improvement of people's welfare is the purpose and foothold of development, while the good health of vigorous people and prolonged life expectancy are important aspects of welfare. To establish a well-off society in an all-round way is to invest in people in an all-round way, in which the yield from investment in 1.3 billion people's health is far greater than the loss caused by unsafe health conditions. Thus it is the most profitable investment of the government, which is also most beneficial to improve fairness. The government's function is to make full use of the limited health resources, to improve greatly the availability of the basic public health services in underdeveloped areas and among people of low income, to narrow the health gap between the rich and the poor and then to improve the health level of the whole nation. As a result, the following should be accomplished.

First, governments at different levels should increase input into the public health services. In 2000, the expenditure for health in China accounted for 5.3 percent of GDP, just higher than 5 percent, the lowest limit of $\mathrm{WHO},{ }^{10}$ of which the public health expenditure from the government's budget and the society amounts to only 39.4 percent of the total health expenditure, while this percentage in high income countries is 71 percent. ${ }^{11}$ The expenditure on health institutions makes up only 1.71 percent of the nation's financial expenditure and 9.94 percent of the expenditure on educational, scientific and cultural institutions (see Table 6.8). Health expenditure for the public sector should be invested in key public objectives (such as the control of epidemic diseases), and should ensure that enough resources are used in the impoverished population's health service. If the public expenditure is not enough, the development of the basic public health service will be limited. As a result, the objective of covering the whole population and improving fairness is unlikely to be realized. Therefore, governments in various levels should increase the percentage of health expenditure in their budgetary expenditure and GDP, and make the input into basic public health greater. The $\mathrm{CMH}$ report has argued that as for the health budget for countries of low and middle income, it is feasible that their GNP will increase by an average of 1 percent by 2007 and by 2 percent by 2015 based on the current level.

Secondly, the inputting direction of health expenditure is to be altered; the health resource is to be distributed effectively, and the availability of the basic public health service is to be increased. The input of health expenditure should be directed toward the rural areas and organizations at the grass-roots level, but 
Table 6.8 China's health expenditure (1991-2000)

\begin{tabular}{|c|c|c|c|c|c|c|c|}
\hline & Unit & 1991 & 1995 & 1997 & 1998 & 1999 & 2000 \\
\hline Total health expenditure & $\begin{array}{l}0.1 \\
\text { billion } \\
\text { Yuan }\end{array}$ & 888.6 & 2257.8 & 3384.9 & 3776.5 & 4178.6 & 4764.0 \\
\hline $\begin{array}{l}\text { Budgetary health } \\
\text { expenditure } \\
\text { by government }\end{array}$ & $\begin{array}{l}0.1 \\
\text { billion } \\
\text { Yuan }\end{array}$ & 202.3 & 383.1 & 522.1 & 587.2 & 640.9 & 709.5 \\
\hline For public health service & $\begin{array}{l}0.1 \\
\text { billion } \\
\text { Yuan }\end{array}$ & 151.9 & 270.8 & 362.3 & 410.5 & 449.7 & 498.5 \\
\hline $\begin{array}{l}\text { For public health } \\
\text { insurance }\end{array}$ & $\begin{array}{l}0.1 \\
\text { billion } \\
\text { Yuan }\end{array}$ & 50.4 & 112.3 & 159.8 & 176.7 & 191.3 & 211.0 \\
\hline Social health expenditure & $\begin{array}{l}0.1 \\
\text { billion } \\
\text { Yuan }\end{array}$ & 341.1 & 739.7 & 937.7 & 1006.0 & 1064.6 & 1167.7 \\
\hline Private health expenditure & $\begin{array}{l}0.1 \\
\text { billion } \\
\text { Yuan }\end{array}$ & 345.2 & 1135.0 & 1925.1 & 2183.3 & 2473.1 & 2886.7 \\
\hline $\begin{array}{l}\text { Components of total } \\
\text { health expenditure }\end{array}$ & $\%$ & 100.0 & 100.0 & 100.0 & 100.0 & 100.0 & 100.0 \\
\hline $\begin{array}{l}\text { Budgetary health } \\
\text { expenditure by } \\
\text { government }\end{array}$ & $\%$ & 22.8 & 17.0 & 16.4 & 15.6 & 15.3 & 14.9 \\
\hline Social health expenditure & $\%$ & 38.4 & 32.7 & 27.7 & 26.6 & 25.5 & 24.5 \\
\hline Private health expenditure & $\%$ & 38.8 & 50.3 & 56.9 & 57.8 & 59.2 & 60.6 \\
\hline Percentages of GDP & $\%$ & 4.11 & 3.86 & 4.55 & 4.82 & 5.10 & 5.3 \\
\hline $\begin{array}{l}\text { Health expenditure per } \\
\text { capita }\end{array}$ & Yuan & 76.7 & 186.4 & 273.8 & 302.6 & 331.9 & 376.4 \\
\hline
\end{tabular}

Source: Weishengbu, Weisheng tongji zhaiyao 2001.

Notes: Data in value terms are calculated at current prices.

not cities and big hospitals, so as to emphatically support the health organizations of the countryside and villages. The inputting direction of resources is to be directed toward activities aimed at solving the basic health problems of most people and preventing diseases. The quantity of the resources needed is to be based on the need for medical treatment service and making the most of the limited resources of poor areas. The investment in public health and subsidies to poor patients are not only fair but also highly efficient, because the social benefit of health investment in the poor is higher than the personal benefit, for it can decrease the infant mortality rate of the whole society and prolong the population life expectancy of the society. In contrast, the personal benefit of 
the health subsidy to the rich is higher than the social benefit (our current problem is that more subsidy is given to people of higher income, whether publicly or privately). The efficient policy of distributing health resources should reach the double-goal of enhancing efficiency and improving fairness at the same time.

Thirdly, a new model of governing, good governance, ${ }^{12}$ is to be realized in the health area, which consists of three aspects. First, the function of the government and market in the area of health care should be redetermined. For example, some basic public health services such as prevention and immunity, maternal and children's health care and access to safe drinking water, belong to the typical public products, which should be provided by the government. On the one hand, it is helpful to solve the problem of market failure; on the other hand, disadvantaged people can be protected to promote social fairness. Personal medical treatment and health care belong to the private area, which should be provided by the market, that is, the function of the government should be changed from "vacancy" into "presence" and in the private area of health care the function should be changed from "offside" into "onside." Secondly, the macro-economic policy of the government should be beneficial to health development and the improvement of people's standard of health. For example, the policy of enhancing domestic needs should combine with improving basic public health and improving the system of medical treatment service. Foreign trade policy should help to acquire global knowledge and introduce advanced techniques. When carrying out the anti-poverty strategy, the improvement of the poor population's standard of health should be taken as the core objective. Finally, the model of separation of state power is to be put into practice in health development, that is to say, the local governments apply the public financial resources independently to supply the local public health service, to establish and supervise the health system of medical treatment and to undertake the concrete responsibility of local health development. The central government is mainly responsible for the financial transferred payments and for the provision of nationwide public goods, policies, laws and regulations. All in all, the government should bring health development into the development strategy of the macro-economy, realize the reasonable positioning of its function in the health area, and realize the transformation of the governing model to "good governance" from "bad governance."

Fourthly, we should win over and draw on international aid actively and effectively. We should actively and effectively raise and use domestic funds to develop health care. Further, we should actively strive for and draw on international aid. The committee's suggestion is that countries of low and medium income should ensure that the health system has sufficient funds to operate efficiently and should work to solve important health problems by means of surplus domestic funds, political leadership, transparency and establishing a system in which communities can have a hand in and be responsible for each of the levels below. That is to say, conditions should be created to strive for international aid; reform of the public health department should be carried out to enable its 
budget and purchasing systems to operate normally, and supervision and a system of responsibility should be strengthened. Furthermore, the construction of non-governmental social ability should be promoted and the function of NGOs in using international aid to carry out the aid-the-poor program should be brought into play. In short, "powerful political leadership and the promise of public departments, private departments and non-government communities are needed," and then we can obtain health development resources and apply them to the sectors of greatest need so as to speed up realizing the health development objective of our nation and the international society. 


\section{$7 \quad$ Health insecurity \\ The biggest challenge to human \\ security in China ${ }^{1}$}

In 2004 the Center for Health Statistics and Information of the Ministry of Health officially published "An Analysis Report on the Third National Health Services Survey." ${ }^{2}$ This is a very good and authoritative investigation report on the national conditions of the health of the population. I think that the third national health services survey has a clear aim and the survey is well designed and the method of the survey is scientific; the analysis of the survey is of high quality; the major findings are convincing. It provides background for research of great reference value for getting to know and analyze the national conditions of the health of the population and for mapping out the health development strategy and policies in cities and the countryside. At the same time, it provides extremely important information for realizing the population health objectives of the UN's "Millennium Development Goals." What merits special mention is that the survey report has given the major findings of the previous two health service surveys conducted in 1993 and 1998, which enables us to see the changes and characteristics in the health conditions and health service demand in cities and the countryside over the past ten years and enables us to give an objective evaluation of the past health reform and the effects and problems of public health policies.

But what is the most important and most valuable information about the national conditions of the population's health that the survey report provides? We need to make full use of the rich materials provided by the report and its major achievements to give a more detailed analysis and exploration of the relations between health and development and put forward our proposals as to how to realize the grand goal of building a well-off society in every way while constructing a healthy society. I think the most important and most valuable achievements of the report is that it has revealed the most glaring problem of "health insecurity" of the population in China, which involves the major livelihood of all the 360 million households and 1.3 billion people in the country.

\section{Five major characteristics of health insecurity in China}

Health is an eternal subject of people's conversations. Health and vitality is one of the values pursued by man since his appearance. To ensure the health of the 
people is one of the core objectives for building a well-off society in an allround way in the next twenty years, that is, to enable billions of people to live a healthier, longer and happier life of high quality. ${ }^{3}$

Being healthy, as defined by the World Health Organization (WHO), is more than not being sick. It is a state of complete physical, mental and social wellbeing. The world health survey covers several areas: mobility, self-service ability, pain and discomfort, recognition, vision, sleeping and energy, emotion, a healthy body and mental state, and conditions concerning daily life, work, spirit and emotion. ${ }^{4}$

By health insecurity, we mean that health risk factors cannot be brought under control or that people have been deprived of the basic health rights, such as being unable to enjoy an elementary health service, medical insurance, or having no basic health conditions and having a living environment detrimental to health, being unable to foster a healthy life-style or lacking basic health care knowledge (see Figure 7.1). Health insecurity has become one of the biggest challenges to human security in China. So health security is one of the most important tasks for building a well-off society with health service available to all.

Health insecurity of the Chinese people mainly assumes the following characteristics.

First, health insecurity is multidimensional. This refers to the fact that people may suffer at least two kinds of health insecurity simultaneously: they may live

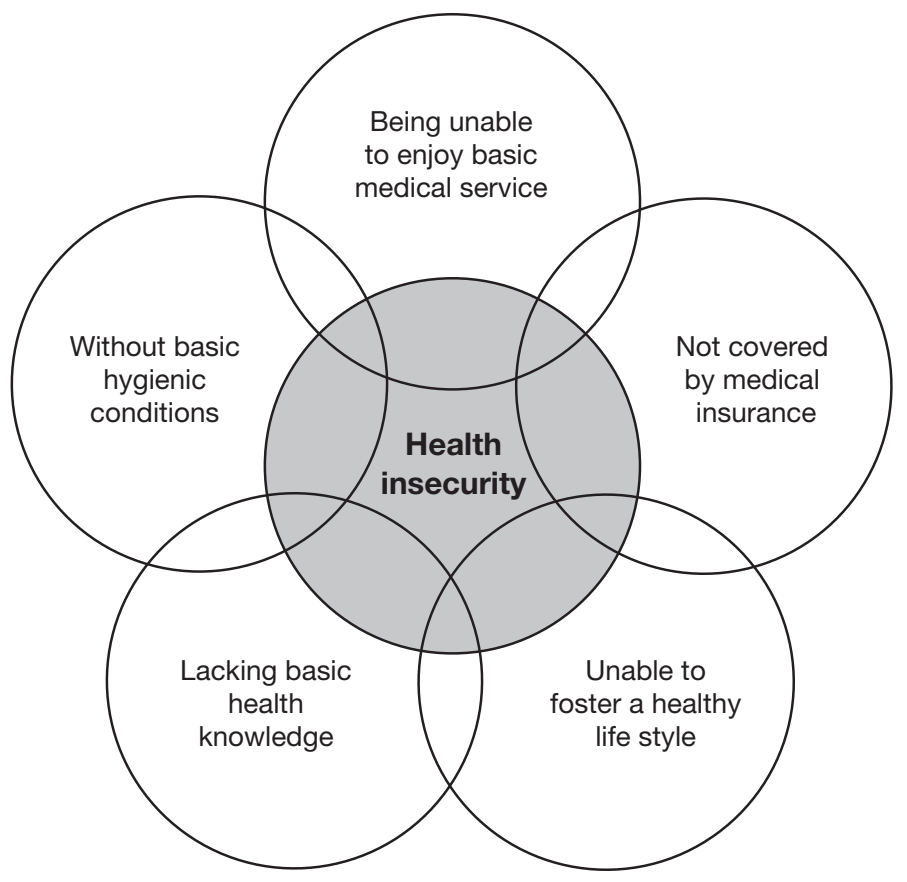

Figure 7.1 Composition chart of health insecurity 
in an environment without hygienic conditions and they may be unable to enjoy elementary medical service. Different groups of people suffer different types of health security.

Second, health insecurity is universal and all-round, existing in different habitats and regions, among people of different income levels, careers and age groups. In terms of regional distribution, health insecurity exists in all regions, not only in rural, but also in urban areas; not only in low-income areas but also in middle-income and high-income areas. In terms of distribution among different groups of people, health insecurity involves all types of population, but especially old people, women and children.

Third, health insecurity covers a large population. As China is a populous country, even if there is a fraction of health insecurity, the absolute figure is considerable.

Fourth, health insecurity exists not only among insecurity-prone people but also causes all kinds of economic costs, including both direct economic costs such as in-patient fees and out-patient medical fees and indirect costs such as losses caused by absence from work due to ill-health. The economic costs in 2003 accounted for about 7 percent of the GDP, including economic costs and mental losses.

Fifth, population health and economic development have formed a "development paradox." Over the past ten years, China's economy has maintained a high-speed growth and the per capita income level has risen greatly. Calculation according to a constant price shows that China's per capita GDP grew by about 1.15 times in 1993-2003 and the urban per capita disposable income grew by 1.01 times and the rural per capita income also grew by 58.7 percent. $^{5}$ But the incidence of diseases and the number of patients also increased and the patients who fail to see doctors or receive treatment also increased in proportion and size. All these have testified to what Premier Wen Jiabao said, that in general, there is the problem of "one leg is long and the other is short" in both economic and social development. ${ }^{6}$ The problem is especially outstanding in the area of health. Although in general China has attained a level of well-off living, China remains the world's largest developing disease economy and society.

\section{Manifestations of health insecurity}

On the basis of the third national health service survey report, we have summed up health insecurity as follows.

\section{The disease incidence in urban and rural areas is as high as 5 billion person/times, nearly half of which were not referred to a doctor}

The disease incidence rose by 16.5 percent from 4.3 billion person/times in 1993 to 5 billion person/time by $2003,{ }^{7}$ increasing by 700 million person/times. The average disease incidence time per person per year rose from 3.63 times in 1993 to 3.86 times in 2003 (see Table 7.1). Among the patients, 21.8 percent 
Table 7.1 Changes in sickness and treatment (1993-2003)

\begin{tabular}{llcc}
\hline & 1993 & 1998 & 2003 \\
\hline Disease incidence (person/time, 100 million) & 42.9 & 47.9 & 50 \\
Total population (100 million) & 11.85 & 12.48 & 12.92 \\
Average disease incidence time per year per person & 3.62 & 3.84 & 3.86 \\
Undiagnosed cases (person/time, 100million) & & & 23.5 \\
Untreated cases (person/time, 100 million) & & 6.3 \\
Number of chronic disease cases (person/time, 100 million) & & 1.6 \\
\hline
\end{tabular}

Sources: Statistics and Information Center of the Ministry of Public Health, Disanci guojia weisheng fuwu diaocha fenxi baogao (Analytical Report on the Third National Public Health Service Survey), Beiji ng: Zhongguo xiehe yide daxue chubanshe (Peking Union Medical College Press), 2004; Guojia tongjiju (National Bureau of Statistics of China), Zhongguo tongji zhaoyao 2004 (China Statistical Abstract 2004), Beijing: Zhongguo tongji chubanshe (China Statistics Press), 2004, p. 38.

thought their disease serious, 51.3 percent though it OK, 24.1 percent deemed it serious and 2.8 percent deemed it not good.

The number of patients who did not refer to doctors in 2003 reached 2.35 billion, about 47 percent of the total number of patients. They refused to go to hospital or see the doctor. The number of patients who did not receive any treatment reached $630 \mathrm{million} /$ times, 12.6 percent of the total number of patients. The proportion of people who failed to receive treatment was 10 percent in cities and 14 percent in the rural areas. Among them, 38 percent did not receive any treatment due to economic difficulty and 70 percent of them did not stay in hospital for treatment due to economic difficulty. In the low-income group in urban areas, about 41 percent of the patients who should have been in-patient did not receive in-patient treatment. Even in the high-income group, about 17.2 percent of the patients who should have been in-patient did not receive in-patient treatment. All the preceding proportions were higher than those in 1998.

The number of the population ill with chronic diseases is large, about 160 million, 13 percent of the total population. The statistical data only include those cases that have been definitely diagnosed by doctors ${ }^{8}$ and do not include those not definitely diagnosed by doctors.

\section{More than 80 percent or one billion of the urban and rural people are not covered by medical insurance}

The number of people who have not been covered by medical insurance over the past ten years rose from 900 million to one billion or from 67.8 percent to 80.7 percent. The number in cities rose from 96.53 million to 300 million. In the rural areas, people who have not been covered by medical insurance dropped from 800 million to 400 million, as the rural population dropped in the period while the proportion of people who are covered by medical insurance rose from 94 percent to 97 percent (see Table 7.2).

Statistical data from the State Statistical Bureau shows that the 1998 basic 


\section{Economic and social transformation in China}

medical insurance coverage was 18.78 million and the figure rose to 110 million by 2003 , about 20.85 percent of the total urban population (523.76 million) or 8.4 percent of the total national population (1292.27 million). Meanwhile, the number of people who have not taken out medical insurance policies rose from 397.3 million to 414.74 million, with the proportion dropping from 95.5 percent to 79.2 percent (see Table 7.3). Even according to these data, the number of urban people who have not taken out insurance policies was 110 million more than the data obtained by the survey. The survey indicates that 300 million to 400 million urban people are still not covered by social medical insurance, let alone the 800 million rural people.

\section{Problems of being in poor health among women and children and people in poor areas are very serious}

Although much headway has been made in China's maternal and child care, still there is a serious problem of being unhealthy. First of all, the percentage of pregnant women with pre-natal examinations rose from 70 percent in 1993

Table 7.2 Urban and rural population not covered by medical insurance (1993-2003)

\begin{tabular}{lrrr}
\hline & 1993 & \multicolumn{1}{c}{1998} & \multicolumn{1}{c}{2003} \\
\hline Urban & & & \\
Without social medical insurance (\%) & 29.1 & 50.2 & 57.0 \\
Without social medical insurance (10 thousand) & 9653 & 20887 & 29854 \\
Rural & & & \\
Without social medical insurance (\%) & 94.2 & 95.37 & 96.9 \\
Without social medical insurance (10 thousand) & 80394 & 79303 & 74469 \\
Nation & & & \\
Without social medical insurance (\%) & 67.8 & 80.3 & 80.7 \\
Without social medical insurance (10 thousand) & 90047 & 100190 & 104323 \\
\hline
\end{tabular}

Source: Rao Keqin, Disanci guojia weisheng fuwu diaocha zhuyao jieguo (Major Findings of the Third National Public Health Service Survey); Guojia tongjiju, Zhongguo tongji zhaoyao 2004, p. 38.

Table 7.3 Urban population not participating in primary medical insurance (1998-2003)

\begin{tabular}{lrrr}
\hline & 1998 & 2000 & 2003 \\
\hline Total population (10 thousand) & 41608 & 45906 & 52376 \\
Participating in primary medical insurance (10 thousand) & 1878 & 3787 & 10902 \\
Not participating in primary medical insurance (10 thousand) & 39730 & 42119 & 41474 \\
Proportion participating in primary medical insurance (\%) & 4.5 & 8.2 & 20.8 \\
Proportion not participating in primary medical insurance (\%) & 95.5 & 91.8 & 79.2 \\
Disposable income per person, urban (Yuan) & 5425 & 6280 & 8472 \\
Medical expenditure per person, urban (Yuan) & 205 & 318 & 476 \\
Proportion of medical expenditure in disposable income (\%) & 4.7 & 6.4 & 7.3 \\
\hline
\end{tabular}

Source: Guojia tongjiju, Zhongguo tongji zhaiyao 2004 (China Statistical Abstract 2004), pp. 99, 103 , and 187. 
to 88 percent in 2003 in the whole country, with that in the rural areas rising from 60 percent to 86 percent. But there are still 15 percent of rural pregnant and lying-in women who did not receive pre-natal examinations, with the number estimated at 1.05 million. Rural hospital birth delivery remains a problem. The percentage of the urban hospital birth delivery rate has reached 93 percent, but that in the rural areas is only 62 percent, with the number estimated at 2.86 million.

Secondly, the health conditions of the newborn have been greatly improved. The proportion of underweight children is 3.1 percent in cities and 3.8 percent in rural areas, all lower than the 16.8 percent in the world and the 9 percent in lower-middle-income countries and 8 percent in upper-middle-income countries. The weight of the newborn in rural areas is very close to that in cities. The situation is good with the planned immunization inoculation of oneyear olds already reaching or exceeding the level of middle-income countries in the world. But the percentage of children under 5 with planned immunization cards is still very small in rural areas, only about 56 percent, with the number of children without planned immunization cards estimated at about 2 million.

Thirdly, the poor areas are low not only in per capita income but also in public health service level, indicating prominent income poverty and health poverty. The survey shows that in poor areas, such as the fourth category rural areas, one-third of the rural population had per capita annual income of only 1183 Yuan in 2003 or only 743 Yuan in real terms, short of the national average of rural per capita income (922 Yuan) ten years ago.

About 60 percent of children do not have regular physical checkups and nearly half of pregnant and lying-in women do not have pre- and post-natal physical checkups. Ninety percent of pregnant women give birth at home. The percentage of households without safe drinking water has reached 5.3 percent and the percentage of households using unhygienic toilets has reached 91.3 percent. Besides, there is a big gap between urban and rural areas in 1990 in terms of the death rate of the newborn, the death rate of infants and children, the death rate of children under 5 and the death rate of pregnant and lying-in women. The life expectancy at birth in cities has caught up with that of developed countries, being 73 years, but the underdeveloped rural areas still belong to the type of less-developed countries.

\section{The size of all kinds of health insecurities is large}

First of all, China has the largest smoking population in the world. It is both the largest tobacco consuming country and the country with the most victims of tobacco hazards. Smoking has become one of the biggest "killers" threatening the health of the people. In the mid-1990s, there was one smoker in every three adults and the total smoking population in the world reached 11 billion. ${ }^{9}$ The national health service survey shows that 47.3 percent of men in China smoke. Although the percentage dropped significantly compared with that ten 
years ago (61.2 percent), it is still higher than the world's average level. The number of men smokers in China was 270 million in 1993, but it was 250 million in 2003, making up about 22.7 percent of the world total. Nationwide, smokers accounts for 26 percent of the total adult population and the total number of smokers in the country as a whole is 260 million, about 23.6 percent of the total world population. The tobacco consumption level in China is the highest in the world, with the annual amount of cigarettes consumed reaching 5,800 per person, averaging 15.9 per person per day. The WHO statistics that cover 58 countries show that there are only two countries whose per capita annual cigarette consumption has topped 5,000 (the other is Iraq). The 260 million smokers consume 1,500 billion cigarettes a year. China's 2003 cigarette production was 35.81 million packets. ${ }^{10}$ Although the tobacco industry is one of the major revenue sources in China, it is one of the main destroyers of human health. According to the 2002 World Bank report, smoking may cause heart troubles and other blood vessel troubles, lung cancer and cancers of other organs. As the tobacco-induced fatal diseases significantly lag behind the development of smoking, developing countries will face serious consequences of smoking for a dozen years to come.

Secondly, China is also a big alcoholic drinks consumer, with the annual direct consumption reaching about 1,000 tons. About 8.2 percent or about 82 million of the people aged 15 and above are regular drinkers. ${ }^{11}$ The per capita consumption of alcoholic drinks in 2003 was $9.39 \mathrm{~kg}$ in cities and $7.67 \mathrm{~kg}$ in the countryside. The average annual alcoholic drink consumption was 492 tons in cities and 589 tons in rural areas, totaling 1,081 tons. ${ }^{12}$ Like tobacco, breweries are major sources of revenue of the country, but excessive drinking has also become one of the main destroyers of human health.

Furthermore, there are still more than 200 million to 300 million people who do not have access to safe drinking water. The current survey data show that as much as 14 percent of the people in the country do not have access to safe drinking water, about 180 million, mostly in the countryside. According to a survey conducted by the Ministry of Water Resources ${ }^{13}$ of the drinking water in rural areas, only 66 percent have met the prescribed standards and the rest, 34 percent, fail to meet such standards. About 300 million people in the rural areas still drink unsafe water and 191 million people drink water containing harmful elements. In the vast rural areas of China, about fifty diseases occur or are spread due to drinking of unsafe water. Drinking water insecurity is the principal reason for water pollution, water-associated endemic diseases and snail fever. At present about 63 million rural people drink water with fluorine content far higher than the prescribed standards and about 38 million people drink bitter water, mostly in the coastal areas of north and east China. There are 110 counties in seven provinces where snail fever has not been brought under control and about 60 million people live in the disease-infested areas (see Table 7.4).

There are still hundreds of millions of people who lack human health knowledge. Only 47.2 percent of the people try to get health knowledge, with 67.5 percent in cities and 39.5 percent in the rural areas. This means that 
Table 7.4 Population without access to safe drinking water (2003)

\begin{tabular}{ll}
\hline & Number (100 million) \\
\hline Population without access to safe drinking water (a) & 1.8 \\
Population without access to safe drinking water (b) & Over 3 \\
Of which, people drinking water with harmful elements & \\
above prescribed standards (b) & 1.91 \\
People drinking high-fluorine water (b) & Over 6300 \\
People drinking bitter water (b) & 3800 \\
People living in snail fever infested areas (b) & 6000 \\
\hline
\end{tabular}

Sources:

(a) Authors' calculation based on the findings of the Third National Public Health Service Survey (Disanci guojia weisheng fuwu diaocha);

(b) Authors' calculation according to the survey by Ministry of Water Resources, Xinhua News Agency, Chengdu, November 28, 2004.

650 million people in the country do not try to get health knowledge. About 25.8 percent of the people who do not know or misunderstand how AIDS is transmitted, with that in the rural areas accounting for 33.9 percent. That means 330 million people in the country do not have a correct understanding of how AIDS is transmitted.

Also, there are about 60 million handicapped people, 8.36 million more than in 1987. All kinds of handicapped people have increased to varying degrees (see Table 7.5).

Lastly, the number of people suffering from health insecurity is considerable (see Table 7.6), involving, directly or indirectly, hundreds of millions of families and a billion people and its impact is bigger than any other factors. In this sense, China is not only a country with the biggest population, but also a country with the biggest number of disease cases. Health insecurity has become the biggest threat.

Table 7.5 Handicapped population in China (1987-2003) (10 thousand)

\begin{tabular}{lrr}
\hline & 1987 & 2003 \\
\hline Total number of handicapped people & 5164 & 6000 \\
Hearing and speech handicapped people & 1770 & 2057 \\
Mentally retarded people & 1017 & 1182 \\
Limbs disabled people & 755 & 877 \\
Vision lost people & 755 & 877 \\
Mentally ill people & 194 & 226 \\
Multiple disabled and other types of disabled persons & 673 & 782 \\
\hline
\end{tabular}

Source: China Disabled Persons' Federation, available on official website: http://www.cdpf.org.cn/ shiye/sj-000a.htm (accessed December 10, 2004). 
Table 7.6 Size of groups with health insecurity (2003)

\begin{tabular}{|c|c|c|c|}
\hline & Urban & Rural & Nation \\
\hline Number of people with chronic diseases & & & 167 \\
\hline Number of cases failing to see doctors & & & 2350 \\
\hline Number of cases untreated & & & 630 \\
\hline Number of people not covered by social medical insurance & 300 & 740 & 1040 \\
\hline $\begin{array}{l}\text { Pregnant and lying-in women who fail to receive pre-natal } \\
\text { checkups }\end{array}$ & & 1.05 & \\
\hline Number of lying-in women not delivering in hospital & & 2.86 & \\
\hline Number of children without planned immunization cards & & 1.99 & \\
\hline Smoking population & & & 260 \\
\hline Number of regular alcoholic drinkers & & & 82.00 \\
\hline Number of people failing to try to get health knowledge & & & 650 \\
\hline $\begin{array}{l}\text { Number of people without correct knowledge about how } \\
\text { AIDS is transmitted }\end{array}$ & & & 330 \\
\hline Population without safe drinking water & & & $180-300$ \\
\hline $\begin{array}{l}\text { Iron-deficient anaemia and vitamin and mineral deficient } \\
\text { population (a) }\end{array}$ & & & 250 \\
\hline Legally reported cases of communicable diseases (b) & & & 2.48 \\
\hline Number of rural households without standard toilets (c) & & 122.11 & \\
\hline Population without regular physical exercises (d) & & & 800 \\
\hline Disabled population (e) & & & 60.00 \\
\hline
\end{tabular}

Sources: Rao Keqin, Major Findings of the Third National Public Health Service Survey; Guojia tongiju, Zhongguo tongi zhaiyao 2004, p. 38;

(a) Xinhua News Agency, September 4, 2004;

(b) Guojia tongjiju, China Statistical Yearbook 2004, p. 868;

(c) Ministry of Public Health, June 9, 2004 (See MPH website);

(d) 2001 National Physical Education Survey: the number of people ages 7-70 who do physical exercises regularly reached 369 million, those who do not do physical exercises regularly reached about 800 million;

(e) China Disabled Persons' Federation website.

\section{Estimate of economic costs of health insecurity}

Health insecurity has become a prominent social problem, bringing to the society not only sufferings but also huge economic costs. The health service survey provides the data for estimating the economic costs caused directly or indirectly by the poor health of the people. The calculation results are alarming. In 2003 alone, the economic costs came to 800 billion Yuan, about 7 percent of the year's GDP.

The economic costs caused by disease include both direct and indirect losses. The direct economic costs refer to the sum total of direct expenses or cost of the losses caused by disease, including annual treatment fees, out-patient fees, in-patient fees, health care and treatment, medicine expenses and nutritional, travel and transportation costs of patients receiving medical services; the indirect economic costs caused by disease refer to losses caused to society and family wealth by absence from work (labor) due to sickness and premature 
death. The measurement is the number of days absent from work converted into money by a given economic standard, such as losses in RMB.

First of all, we try to calculate the direct economic costs caused by disease based on the data provided by the survey. We divide the direct losses into outpatient fees and in-patient fees. Given that each person makes 0.134 hospital visits every two weeks, the total expenses per visit (including medical and other fees) is 127 Yuan. Based on this figure, the amount of fees that occur due to hospital visits is 435.6 billion Yuan a year, amounting to 3.7 percent of the GDP. Given that the number of hospitalization is 0.036 times per person per year, the total cost per time (including medical and other fees) is 3,904 Yuan, and the total annual expense is 181.5 billion Yuan, 1.6 percent of the GDP. The total direct economic cost due to disease is 617.1 billion Yuan, 5.3 percent of the GDP. This does not include fees that occur from self-treatment without seeing doctors.

Then, let's try to calculate indirect economic costs from disease. Based on the data from the survey, given that every person rests 0.194 days every two weeks and the total employment is 744 million in the country, the loss in the two weeks is 144 million workdays and the annual loss would be 3.753 billion workdays. Suppose each person is hospitalized 0.036 times per year, the total number of days each time of hospitalization (including waiting days and days in hospital) is 14.1 days. Calculating according to the total employment of 744 million and a five-day week, the loss would be 270 million workdays, and the total annual loss would be 4.023 billion workdays. The average labor productivity in 2003 was 15,700 Yuan. Suppose every person works for 300 days a year, the per capita output per workday is 52 Yuan, the losses due to absence from work for sickness would be 209.2 billion Yuan, 1.8 percent of the GDP.

Finally, let's calculate the total losses from disease, that is, direct and indirect losses. Our preliminary estimate is that the economic cost of disease in 2003 totaled 826.3 billion Yuan, 7.1 percent of the year's GDP.

We may also adopt a second method for calculation, that is, calculating the total cost of medical and health services in cities and the countryside from the total medical and health care spending per person. The total for 2003 was 338.3 billion Yuan, 2.8 percent of the GDP (see Table 7.7). Such spending reflects family investment in health and medical and health care due to unhealthiness or disease. We have found that this kind of spending in the total consumption spending is increasing.

All these show that China is not only a society with the largest health insecure population but also a developmental disease economy with huge losses caused by health insecurity. ${ }^{14}$

\section{Review and evaluation of health development and reform objectives}

First, let us review and evaluate the health development objectives of the government. In December 1990, the seventh plenary session of the Thirteenth Party 
Table 7.7 Estimated economic costs of disease (2003)

\begin{tabular}{lll}
\hline & $\begin{array}{l}\text { Absolute } \\
\text { figure (billion) }\end{array}$ & $\begin{array}{l}\text { Percentage } \\
\text { of GDP }\end{array}$ \\
\hline $\begin{array}{l}\text { Estimates based on the data obtained by the survey: } \\
\text { Direct losses }\end{array}$ & 617.1 & 5.3 \\
$\quad$ Of which, Aout-patient fees & 435.6 & 3.7 \\
$\quad$ in-patient fees & 181.5 & 1.6 \\
Indirect losses & 209.2 & 1.8 \\
Total & 826.3 & 7.1 \\
Calculated based on data of per capita medical and & & \\
health care spending in urban and rural areas: & & \\
Medical expenditure of urban residents & 249.3 & 2.1 \\
Medical expenditure of rural residents & 89.0 & 0.7 \\
Total & 338.3 & 2.8 \\
\hline
\end{tabular}

Source: Ministry of Health, Disanci guojia weisheng fuwu diaocha zhuyao jieguo; Guojia tongijiu, Zhongguo tongji zhaiyao 2004, p. 16.

Central Committee adopted the "Proposals of the CPC Central Committee on Formulating the Ten-Year Program for Social Development and the 'Eighth Five-Year Plan'." The document proposes that by 2000 the people's living standards would gradually reach the well-off level. The well-off level at the time refers to further improving the quality of life on the basis of adequate food and clothing, that is, both urban and rural people will have enough to spend on clothing, food, housing, articles used daily and travel. Only Article 48 mentions the development of health care to improve the health levels of the people. ${ }^{15}$ But this program fails to put forward any development objectives and targets in public health.

"China's Outlined Children's Development Program for the 1990s" formulated in 1991 put forward health development objectives and some quantified targets. These targets have been met (see Box 7.1). The outlined program mentioned raising the use and availability of hygienic toilets for 2001. In 1995, the target was revised as raising the proportion of sanitary toilets to 40 percent. According to the data provided by the Ministry of Health, 110 million households had built such toilets, with the popularization rate reaching 415 percent. ${ }^{16}$

Five years later, the fifth plenary session of the Fourteenth CPC Central Committee adopted in September 1995 the "Proposals of the CPC Central Committee for Formulating the Ninth Five-Year Plan for National Economic and Social Development and the Objectives for Years Running up to 2010." The proposals urged active efforts to develop health services in order to realize the objective of enabling everyone to enjoy primary health care services. ${ }^{17}$ But this plan failed to spell out specific objectives and targets. In 1995, the State Council approved the "Outlined Program for China's Women's Development (1995-2000)," which puts forward objectives and quantified targets for the health 


\section{Box 7.1 Objectives for health development of women and children and their implementation}

Objectives of children's health development set out in the "Outlined Program for the Development of Children in the 1990s":

1 Cut by one-third 1990's death rate of infants and children under 5 .

2 Halve the death rate of pregnant and lying-in women by 1990.

3 Halve the incidence of medium and serious malnutrition of children under 5 by 1990 .

4 Population benefiting from the water improvement project in water short rural areas to reach 95 percent by 2000 .

5 Universally raise the practice of rendering sewage water and garbage harmless and sanitary toilets.

Objectives on women's health set out in the "Outlined Program for Women's Development of China (1995-2000):":

1 Bring the health care coverage of pregnant and lying-in women and their health education to 85 percent.

2 Bring the new birth delivering method in rural areas to 95 percent.

3 Raise the percentage of hospitalized birth of rural women so as to halve the death rate of pregnant and lying-in women on the basis of 1990.

4 Bring the immunization inoculation against tetanus and other diseases of child-bearing women and expectant mothers to 85 percent and eliminate tetanus of the newborn.

\section{Implementation results}

By 2000, the country opened 3,180 maternal and child care organizations, built a three-tier medical care network at the county, township and village levels. The death rate of infants and children under 5 was lowered from $50.2 \%$ and $61 \%$, respectively, at the beginning of the 1990 s to $32.2 \%$ o and $39.7 \%$ by 2000 and the death rate of pregnant women and lying-in women was lowered from 1989's $94.7 / 100,000$ to $53.0 / 100,000$ by 2000 . Children receiving planned immunization of four kinds of vaccines reached over $90 \%$; polio was eliminated; the percentage of underweight children under 5 was reduced from 1990's 21 percent to 10 percent by 2000; iodine was universally added to table salt. 
development of women. Most of its targets have been realized (see Box 7.1). In March 1996, the fourth session of the Eighth National People's Congress adopted the "Ninth Five-Year Plan for National Economic and Social Development." The plan set the goal of enabling 90 percent of the people to benefit from rural water improvement projects by 2000 and the percentage of rural families enjoying tap water would reach 80 percent. According to the data provided by the Ministry of Public Health, the percentage of people benefiting from rural water improvement projects had reached 93 percent by the end of 2000 and 50 percent of rural families had had tap water to use. ${ }^{18}$ Obviously the goal for the use of tap water was far from being realized.

The minimum standards (with county as unit) for "Health Service for all by 2000 " are specified in the "health and anti-epidemic policies, laws and standards" but many of the targets have failed to be met within the prescribed time limit.

Five years later, the "Outlined Tenth Five-Year Plan for National Economic and Social Development" approved by the fourth session of the Ninth National People's Congress in March 2001 set the health development goals as follows: Continue to improve the urban medical service level and rural medical service facilities and further raise the health level of the people. Build a sound rural elementary health service system, with emphasis put on strengthening the health service infrastructure and developing cooperative medical services according to actual local conditions so as to resolve the problem of rural areas lacking basic medical services. ${ }^{19}$ The Tenth Five-Year Plan set clear objectives for all areas including income, education and housing but excluding health services. The Western China Development Program for the Tenth Five-Year Plan period put forward objectives for the death rate of rural pregnant and lying-in women and the newborn, but the objectives were not quantified. We have also seen the twelve key special programs for the Tenth Five-Year Plan period, but health development is excluded, without any clear objectives. Naturally, it is hard to have resolute actions in this regard.

The Sixteenth CPC National Congress in 2002 mentioned the improvement of the health of all the people and stressed the improvement of rural medical and health services and the improvement of the medical care level in urban and rural areas.

Now, let us give a review and evaluation of the objectives set by the government with regard to reform of the social medical insurance system. Providing institutional arrangements for social medical insurance is one of the major areas for government intervention. ${ }^{20}$ This is also one of the important objectives for reform of the economic system. But the objectives have not been realized.

Article 27 of the Decisions on Problems Concerning the Establishment of a Socialist Market Economic System adopted at the third plenary session of the Fourteenth CPC Central Committee in 1993 provided for the establishment of a social medical insurance system for urban workers, with work units and individuals sharing the medical cost and urged places with poor conditions to develop and improve rural cooperative medical services. 
Article 35 of the Proposals of the CPC Central Committee for Formulating the Ninth Five-Year Plan for National Economic and Social Development and Objectives for Years Running up to 2010 adopted at the fifth plenary session of the Fourteenth CPC Central Committee in 1995 provided that during the Ninth Five-Year Plan period, the country should accelerate the reform of the old-age, unemployment and medical insurance system so as to initially give shape to a social security system that integrates social insurance with social relief, social well-being, job arrangements for families of soldiers and social mutual assistance, with individual accounts. ${ }^{21}$

By the end of 1997, more than 3.6 million workers and retired people of state-owned enterprises were covered by a medical insurance system, accounting for 2.5 percent of the total number of workers in the country. This, plus the workers and retired people covered by social pools for major diseases, meant that the coverage of the medical insurance system reached 11.3 percent. In some cities, reform of the medical insurance system was carried out only in government organs and publicly financed institutions, and the workers and many enterprises, especially those in the collective, private and foreign-funded sectors, did not participate in the reform at all. So, the State Council issued the decision on the establishment of basic medical insurance in urban areas in December 1998, deciding to introduce the social insurance medical service system financed by social pools and individual accounts (employer units contribute about 6 percent of the total payroll and workers contribute 25 percent of their wage income). ${ }^{22}$

The medical insurance system is the most elementary in China and it needs full commitments by political leaders. Over the past ten years, political leaders have made a series of political commitments, but the coverage of social medical insurance has become lower and lower and the population who are not covered by social medical insurance has become larger and larger. Human health insecurity has become more and more outstanding.

This shows that relative to economic development objectives, health development objectives are but "soft targets" that can be either fulfilled or unfulfilled; relative to material and capital input, health investment is but a "soft investment" that can be more or less; relative to other institutional reforms, the social medical insurance system reform is but a "soft reform" that can be either advanced or postponed.

\section{Conclusions: act to cope with major challenges to human health insecurity}

The biggest development opportunity facing China in the twenty-first century is economic globalization and the biggest challenge facing China is human insecurity. Human insecurity will become a major challenge to China in its long-term development and social stability in the twenty-first century. Human insecurity mainly comes from all kinds of conflicts in the process of economic globalization and economic transition. If we say human development is to increase 
choices and improve quality, human security refers to people's free and safe realization of their choices.

In the twenty-first century, China is still facing all kinds of grave human insecurity and development challenges to human development. They are: employment insecurity, income insecurity, old-age insecurity, health insecurity, cultural insecurity, social insecurity and environment insecurity. ${ }^{23}$

China has a large population but little cultivated land. The food problem for the 1.3 billion people has always been a major development task for the Chinese government over the past half century. One of the major achievements of reform and development is the success in basically solving the inadequate food problem. In 1998, China's total grain output reached a record 510 million tons. But one of the most outstanding development problems, namely, human health insecurity, has been neglected by the people, especially governments at all levels.

The third national health services survey has clearly demonstrated that the biggest challenge facing the Chinese people is health insecurity. How to solve this problem for its 1.3 billion people - this is one of the major tasks of development for the Party and the government. During the SARS crisis, Party General Secretary Hu Jintao, for the first time, put the people's health in the first place. This is a major political commitment. Now it is necessary to adopt effective measures to fulfill the commitment.

The progress of China in improving human health will not only benefit the 1.3 billion Chinese people but will also help realize the Millennium Development Goals of the international community. Of the eight UN Millennium Development Goals, three are in the area of health. Of the eighteen sub-objectives, seven are in the area of health. Of the forty-six targets, seventeen are in the area of health. So public health and the health of the people are the most important objectives for the Millennium Development Goals. This is a full demonstration of the human-based approach to development and a fundamental purpose of human development. 


\section{Developing human resources to cope with an aging society ${ }^{1}$}

\section{Introduction}

An aging society refers the process by which the proportion of the aged population to the total population has constantly increased. When the proportion of people aged 60 and older reaches over 10 percent of the total population or when the proportion of people aged 65 and older reaches 7 percent of the total population, the country or the region is considered an aging society. Globally, population aging reflects changes in the age structure. It is an inevitable result of the transition from a high birth rate and high death rate to a low birthrate and low death rate. But countries vary in the speed and scale of population aging and the concomitant economic conditions. Aging in developed countries is a concomitant of urbanization and industrialization and it therefore assumes an incremental process. When the population aged 65 and above reaches 7 percent, per capita GDP usually reaches 10,000 US dollars and the pressure on the economy is not big. However, in China, the demographic transition was late and fast and the scale of the population is large and the corresponding industrialization and urbanization are still in the process of development with low per capita income. ${ }^{2}$ The impact of population aging is, therefore, a problem that cannot be ignored.

The proportion of China's aging population will experience an accelerated spiraling, high speed growth, deceleration and steadying off process after entering the twenty-first century. At the same time, the proportion of the workingage population will drop and the old age population that needs support will rise. Such changes in the population structure will have a profound impact on the economy. It will lead to a series of changes in economic variables such as labor, savings, investment and consumption and will influence the long-term development of the economy. It will bring about heavy burdens on society and pose a challenge to the social security system. How should China cope with the rapid arrival of the massive aging society? How can China solve the problem of providing for the aged while maintaining sustainable development? It is generally believed that it is necessary to accelerate the pace of setting up and improving the old age security system, such as raising funds for the aged in different ways and solving the debt problems of the basic old age insurance fund, improving 
the management of old age security funds and improving the returns to the funds. There are other scholars who propose setting up a security system with multiple pillars including the state, communities and families. All of these are good ways to solve the old age support problem. But for China, the old age support system will take a long time to improve. In the face of the tremendous pressure of an aging population and its impact on economic development, these measures are, to a large extent, to take up challenges in a passive way. This chapter considers that the human resource represented by education is an important factor affecting the old age support capability of an individual. In the next few years, the level of human capital in the total population will be low after entering the aging population stage and that part of the population with the lowest level of human capital will have the most difficulty in their old age. On the other hand, taking the society as a whole, human resources are an important source for promoting future economic growth and will provide enough resources for supporting the elderly. On this basis, this chapter puts forward a new line of thought for coping with the aging society, that is, to make great efforts to develop human resources and make it a "reserve mechanism" and "adaptation mechanism" to cope with the challenges of the aging society and promote sustainable economic growth and economic structural transition.

\section{The trend and challenges of China's aging (1980-2050)}

The development of population aging is closely associated with the drop in the death rate, the rise in life expectancy at birth, and the drop in the fertility rate and birth rate. China's death rate began to drop at the beginning of the founding of the People's Republic of China. In the 1970s, both the fertility rate and the birth rate began to drop, resulting in a gradual change in the population structure. According to such indicators as the proportion of people aged 65 and over, the proportion of working-age population aged 15-64 and the old-age dependency ratio (the ratio of the number of people aged 65 and over to the number of working-age population aged 15-64), the process of China's population aging may be divided into four stages (see Figure 8.1, Figure 8.2 and Figure 8.3). The data before 2000 comes from China's population statistics and the other come from prediction data made by the United Nations in its "Prospects of World Population 2000" using the middle fertility and death rate scheme.

The first stage covers 1980-2000. In the 1980s, the proportion of people aged 65 and over made up 5 percent of the total population. ${ }^{3}$ By 2000 , the proportion reached 7 percent, thus entering the aging society. So this stage may be called the preparatory stage for population aging. The proportion of workingage population during this period rose rapidly, indicating that the supporting burden of the whole population dropped and it is a period in which a population "dividend" began to show itself while the supporting ratio rose slowly.

The second stage covers the period 2000-2015, which is the acceleration stage of population aging. According to the prediction by the United Nations, the proportion of the population aged 65 and over during this period will rise 


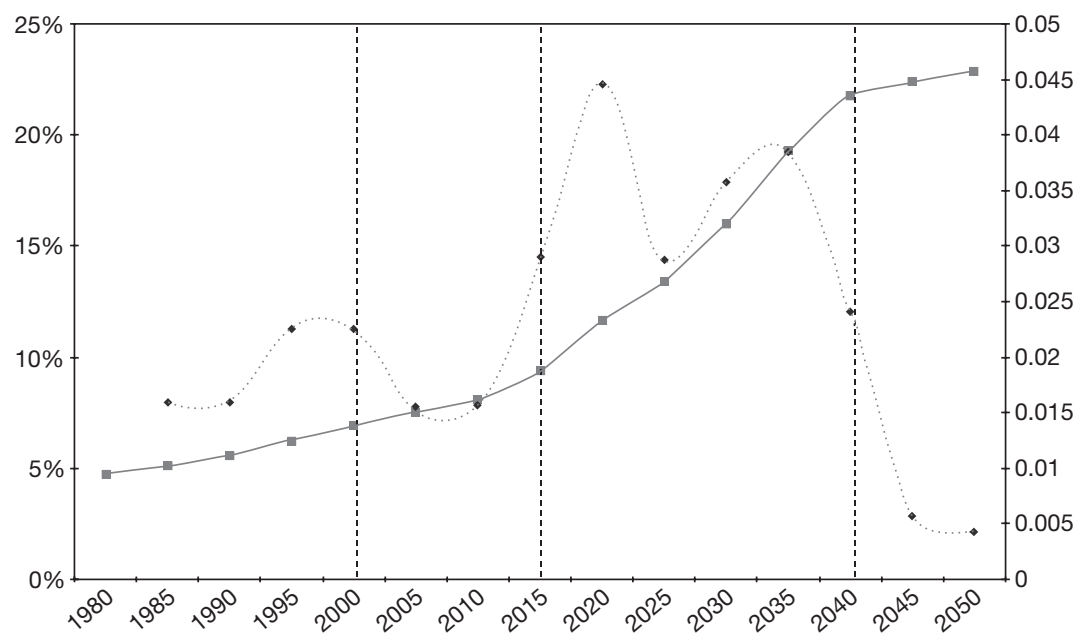

- - Proportion of population aged 65 and above

- Average annual growth of proportion of population aged 65 and above

Figure 8.1 Predicted proportion of population aged 65 and above and its growth rate (1980-2050)

Source: Prediction by UN (medium variant). United Nations Population Division, World Population Prospect 2000.

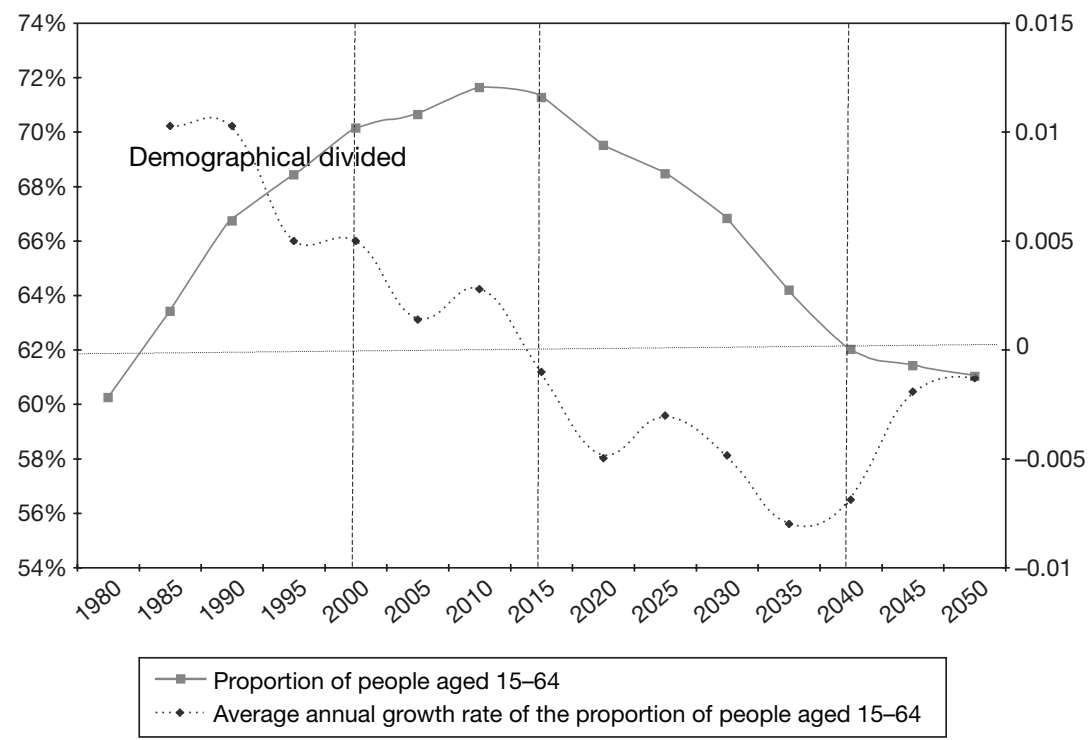

Figure 8.2 Predicted proportion of population aged 15-64 and its growth rate (1980-2050)

Source: Prediction by UN (medium variant). United Nations Population Division, World Population Prospect 2000. 


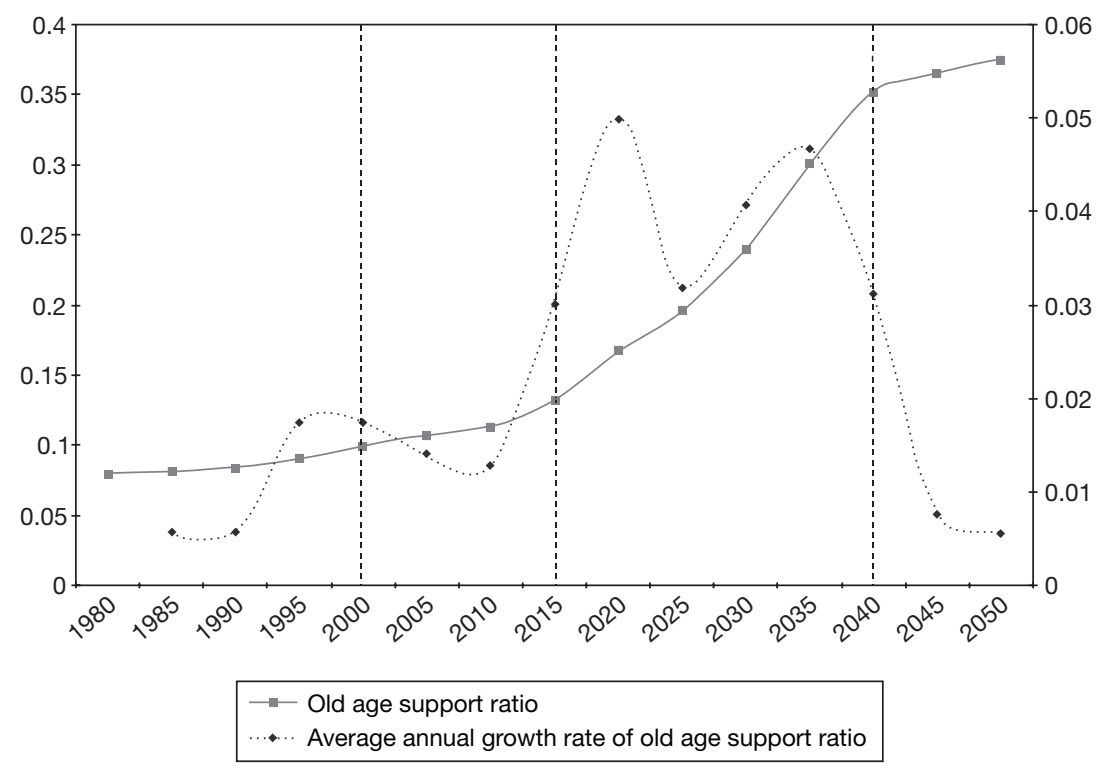

Figure 8.3 Predicted old age dependency and its growth rate (1980-2050)

Source: Prediction by UN (medium variant). United Nations Population Division, World Population Prospect 2000.

from 6.9 percent to 9.3 percent. In the 2000-2010 period, the proportion of this part of the population will increase at an annual rate of about 1.6 to 1.7 percent and up to 2.8 percent in the 2010-2015 period, with the speed of population aging assuming an upward trend. During this period, the proportion of the working-age population in the total population will rise first and then fall, but there will not be much change in general. Changes in the old age support ratio will be similar to changes in the old age population. It will rise slowly in 2000-2010, but it will begin to pick up speed after 2010 .

The third stage covers 2015-2040, which will be a high speed growth period. The proportion of the population aged 65 and older will rise from 9.3 percent to 21.4 percent, and peak from 2015-2020 and from 2030-2035, with an annual growth around 4 percent. The proportion of working-age population will drop quickly, by nearly 10 percentage points from 71 percent in 2015 down to 62 percent by 2040 . The old age support ratio will rise to 0.35 by 2040 , that is, 2.85 working-age persons supporting one old age person. The burden of supporting the aged in the whole country will rise significantly. The main reason for this trend is that the baby boomers in the mid-twentieth century would enter old age. But the result of the intensified family planning efforts toward the end of the 1970s would begin to show up, with the working-age population reduced, thus intensifying population aging.

The fourth stage covers 2040-2050, which will be a period of deceleration. During this period, the annual growth in the proportion of old age population 
would drop to about 0.6 percent. Still, the number of people aged 65 and over would continue to rise to 331 million by 2050, whose proportion would reach 22.7 percent. The working-age population would continue to drop, but at a slower pace. The speed of the rise in the proportion of old age support ratio or old age dependency ratio would also slow down, to reach 0.37 by 2050 with 2.7 working-age persons supporting one old age person.

Unlike many developed countries, China has rapidly completed its demographic transition, making it "grow old before being rich." It can be seen in Figure 8.4 that even if calculated by the PPP method, China's per capita GDP is much lower than that of Japan and America when they had the same degree of aging. In the following couple of decades, aging will exert great challenges upon China. First, social security burdens will become heavier and the pressure on the central finance will increase. Statistics shows that in the 23 years from 1980 to 2003, the pension of retirees increased by more than 60 times from 5.04 billion Yuan to 414.9 billion Yuan. ${ }^{4}$ The proportion in the GDP has gone up continuously. During the same period, the ratio of on-the-job workers to retirees assumed a downward trend, dropping from 10.1:1 in 1982 to 3.2:1 by 2001 (see Figure 8.5). China currently still continues using the same retirement from work which is age 60 for male, 50 for female and 55 for female

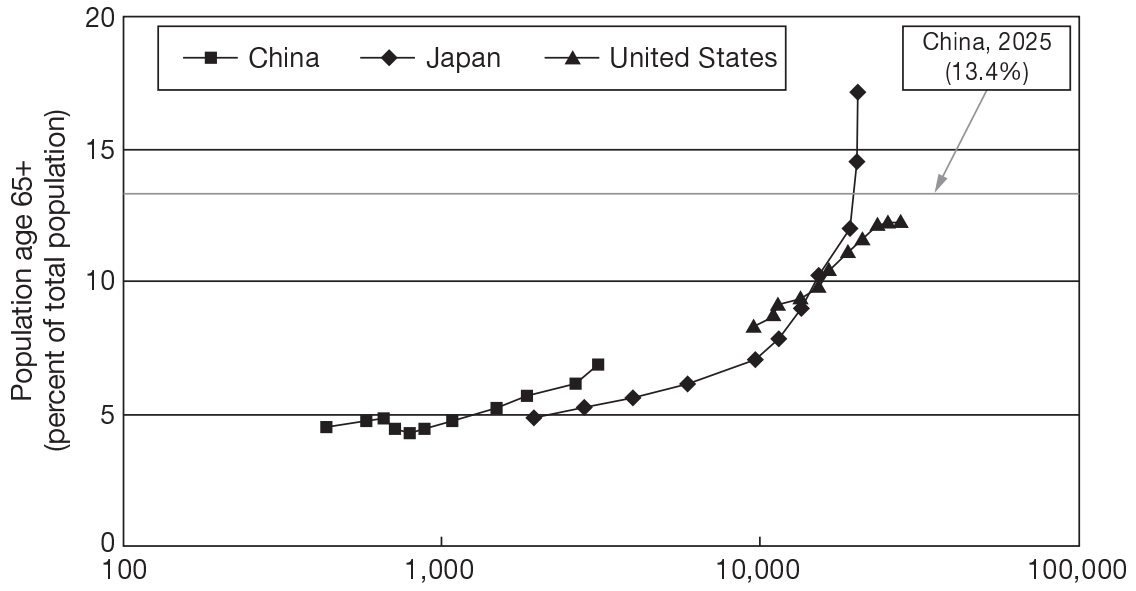

Per capita GDP (1990 international Geary-Khamis dollars)

Figure 8.4 Per capita GDP vs population aged 65+: China, Japan and the United States (1950-2000)

Sources: Nicholas Eberstadt, "China's 'Triple Bind': Demography, Economics and Health in an Aging Low-income Society," presented at CSIS/CASS Conference on Preparing for China's Aging Challenge, Beijing, China, April 19-20, 2004. Data of per capita GDP are quoted from A. Maddison, The World Economy: A Millennial Perspective, Development Centre Studies, OECD: Paris, 2001, Tables C1-c and C3-c. Data of population are quoted from United Nations Population Division, World Population Prospects: The 2002 Revision, available at http://esa.un.org/unpp (accessed June10, 2005). 


\section{2}

cadres. This retirement age is among the lowest in the world. ${ }^{5}$ Furthermore, as life expectancy increases, the time for the retirees to draw money from social plans will become longer, which will definitely put more pressure on social security. Now the remaining life length after retirement is eighteen years for Chinese people, close to that of the OECD countries. If we keep the retirement age constant, the remaining life length will exceed that of the OECD countries in 2020. ${ }^{6}$ Secondly, aging will influence labor force resources and in turn influence the impetus and pattern of economic growth. The impact of aging on the labor force can be viewed from two aspects. One is that the number of workingage population will be reduced, making it difficult for the economic growth pattern relying on the number of laborers to be maintained. However, this will not be a problem for China for quite a long time. The other and more important aspect is the change of age structure of the working-age population. The ratio of people aged from 15 to 44 to people aged 45 to 49 was 81.1:18.9 in 1990 and will be 65.5:34.5 in 2020, and 62.8:37.2 in 2050.7 Due to the difference in physical force, mental energy and so on among different ages of laborers, the change of age structure may have some negative impacts on the economy. From an international perspective, the decrease of working-age population and change of age structure will increase the cost of labor and reduce the comparative advantage of China in its abundant low cost labor, which will depress the long term economic growth potential.

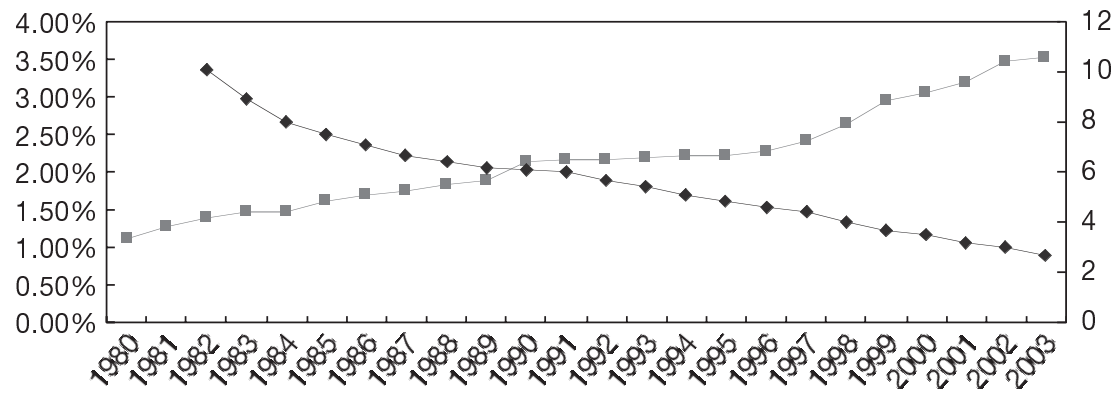

$\multimap$ Retiree pension/GDP $\multimap$ On-the-job workers/retirees

Figure 8.5 Percentage of pensions of retirees in GDP and ratio of on-the-job workers to retirees (1980-2003)

Sources: Percentage of pensions of retirees in GDP comes from Guojia tongjiju (National Bureau of Statistics), Zhongguo tongji nianjian 2004 (China Statistical Yearbook 2004), Beijing: China Statistics Press, 2004. Data for the ratio of on-the-job workers to retirees come from Guojia tongjiju (National Bureau of Statistics), Zhongguo laodong tongji nianjian 2004 (China Labor Statistical Yearbook 2004), Beijing: China Statistics Press, 2004.

Note: All calculations are at the year's current prices. 


\section{Human capital and old age support}

China's current social security system is still not perfect, with a low percentage of participation in endowment insurance (the number of workers joining in the basic old age insurance policies is about 40 percent of the total on-the-job workers) and the pension payment is at a low level. For the people who have not participated in the old age insurance and whose pension payment is low, their old age security is mainly determined by the income level and work age on the job. Empirical study on China shows that human capital denoted by educational level is an important factor determining income. Return rates of different educational levels are different. The higher the educational level, the higher the return rate. The differences in the returns of different educational levels are still increasing during the process of economic development (see Figure 8.6). This shows that human capital leads to the enlargement of income gaps. The situation for people with low human capital levels will get worse. In addition, the income changes are also different during the lifetime of people with different levels of human capital. P. Cipollone studied changes in income with the change in age for people with different levels of education ${ }^{8}$ (see Figure 8.7). From the figure, we can see that for people with higher levels of education, the income level would rise higher and the time for income to drop would also come late. That is to say, the life-long income of people with fairly high levels of human capital would be much higher than those with a lower level of human capital and their work and income are not limited to their age. So the level of human capital has a significant impact on the life-long income and the income in the old age stage, especially for those without old age insurance or with a low pension, whose level of human capital would be an important factor in determining the security of their life during old age. People with a low level of human capital will become the "disadvantaged group" in old age.

Figure 8.8 shows the average schooling years by age of urban and rural populations in 2000. As is known to all, there is a big gap in the total level of education between China and developed countries. ${ }^{9}$ The older the age group, the lower their educational level. In 2000, the average years of education received by old people aged 65 and above were only four years. The old age population section on the left side of the figure would gradually enter the old age stage. The people in the 45-55 age group who would enter the old age stage by 2020 would have eight years of education on average, similar to the junior secondary level. Future population aging will not only be large in number but also fast in growth. It is an aged population with a low total level of human capital. They will hardly be able to support themselves and that will add to the already heavy burdens on society.

Here, it is necessary to point out the challenges of aging faced by a special group. This group is deeply ingrained with different stages of development in the history of New China. They were born during the baby boom period of the 1950s soon after the founding of New China. At the time, the national economy was restored and developed and society was secure and people lived in peace. 


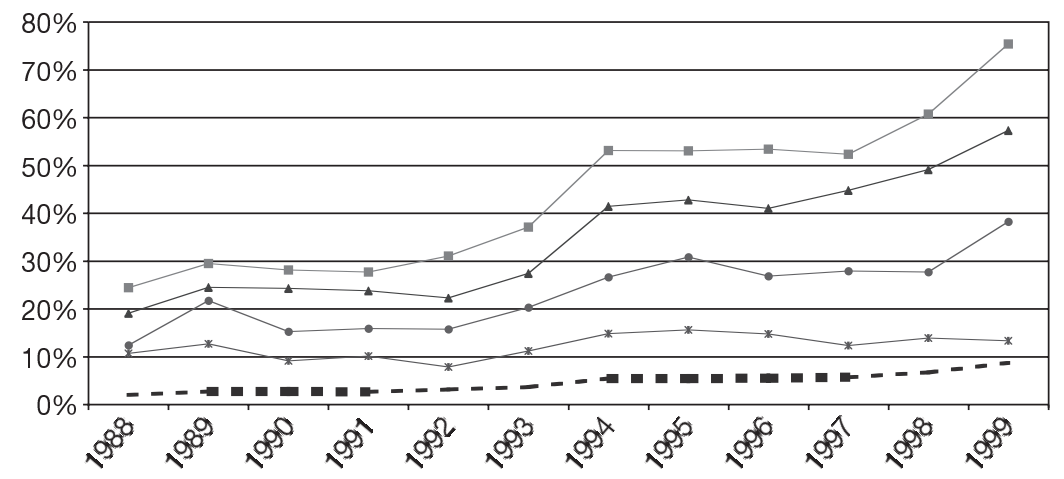

- - Returns on education

- - Comparison between higher and elementary education

- Comparison between technical education after middle school and elementary education

$\rightarrow$ Comparison between senior middle and elementary schools

* Comparison between junior middle and elementary schools

Figure 8.6 Return rate of education (1988-1999)

Sources: A. Park, Y. Zhao et al., "The Growth of Wage Inequality in Urban China, 1988 to 1999," Publishing on the Internet, Washington, DC: World Bank Group. Available at http://poverty2.forumone.com/library/view/13933 (accessed February, 2004).

Note: In China, primary school is six years, junior secondary school is three years; senior secondary is three years. Both junior and senior secondary belong to middle school education.

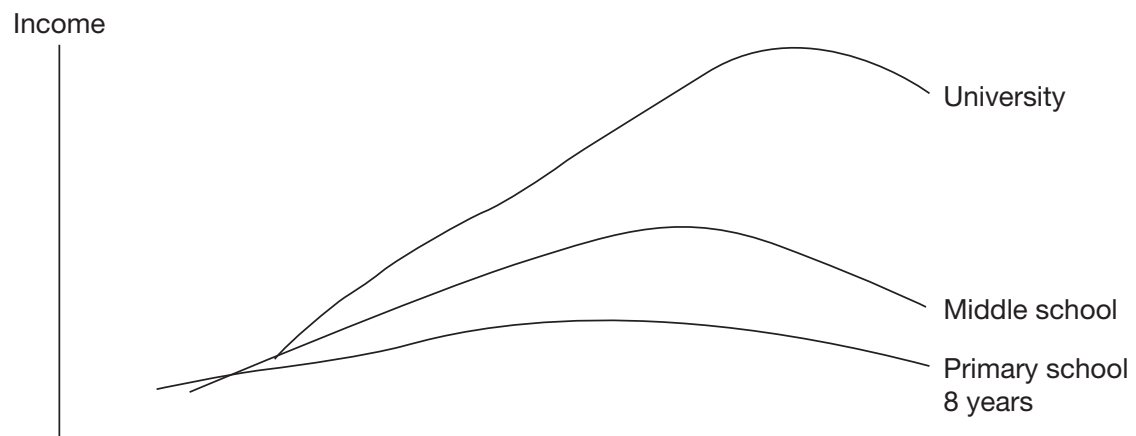

Age

Figure 8.7 Income curve of age by level of education

Sources: P. Cipollone, "Education and Income," International Encyclopedia on Education Economics, Beijing: Zhongguo gaodeng jiaoyu chubanshe (China Higher Education Publishing House), 2000, p. 182. 


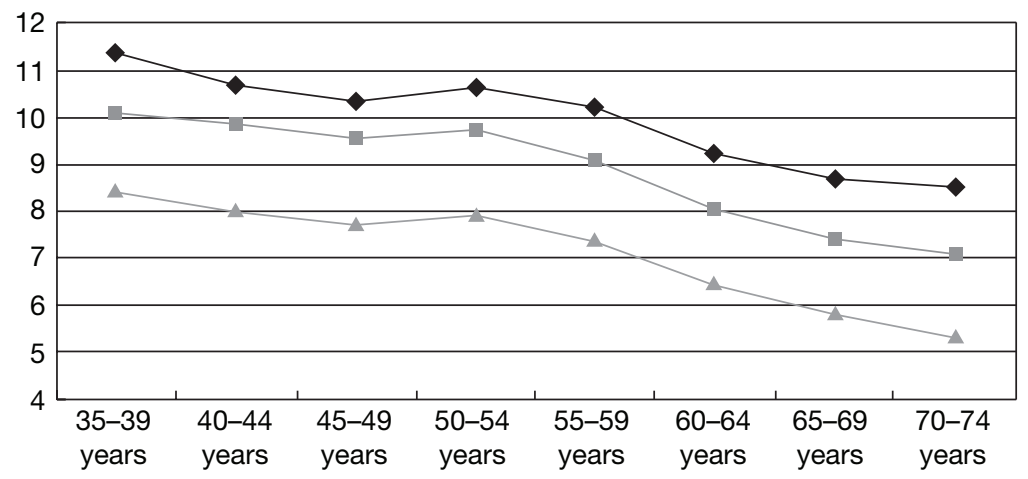

$\multimap$ City $\rightarrow$ Country and town $\rightarrow$ Rural area

Figure 8.8 Distribution of average level of education by age in urban and rural areas in 2000

Source: Guojia tongjiju (National Bureau of Statistics), Statistical Data of Fifth National Population Census conducted in 2000.

During the first five-year plan period, the first baby boom period appeared (see Figure 8.9). During the period of the 1960s and 1970s when they entered school age, the so-called "Great Cultural Revolution" took place, interrupting the school life of most of the students. This group of people suffered a tremendous opportunity cost during the revolution, which can be called a "human capital shortage" (see Figure 8.10). The middle and late period of the 1990s felt the consequences of a lay-off or "unemployment" tide brought about by the reform of state-owned enterprises. As they were older in age and their educational level was not high, they had to bear the brunt of the adverse tide. The proportion of layoffs and unemployment is the highest among this group of people. They have in fact become the direct bearers of the cost of economic transition. Survey data show that the "cultural revolution co-efficient" of all age groups (the ratio of the years of education in the Cultural Revolution to full education years) is strongly associated with the layoffs in this age group. This age group is the worst affected (see Figure 8.11). This age group will enter the old age stage around 2015, forming an "old age peak," which will create tremendous pressure on social security and family support. For social security, the payment by the original work units and re-employment service centers will be very big. ${ }^{10}$ Many enterprises have to pay pensions to laid-off workers according to the minimum standards and some enterprises asked the workers to pay or delay the payments. That means that laid-off workers will receive the minimum old age pension in the future. There are also problems in family support with this group of people. This group of people entered the child-bearing age in the 1970s when the state tightened the enforcement of family planning and their fertility rate dropped drastically. Many of them have only one child. This will lead to old 


\section{6}

Economic and social transformation in China

age support problems. This typical disadvantaged group should receive special attention.

In a word, China is facing a tremendous impact and special challenges by population aging to the future economy and society and it is, therefore, necessary to change the method of relying on the amount of labor to stimulate economic growth and relying on old age insurance to solve the old age problem and to seek new countermeasures.

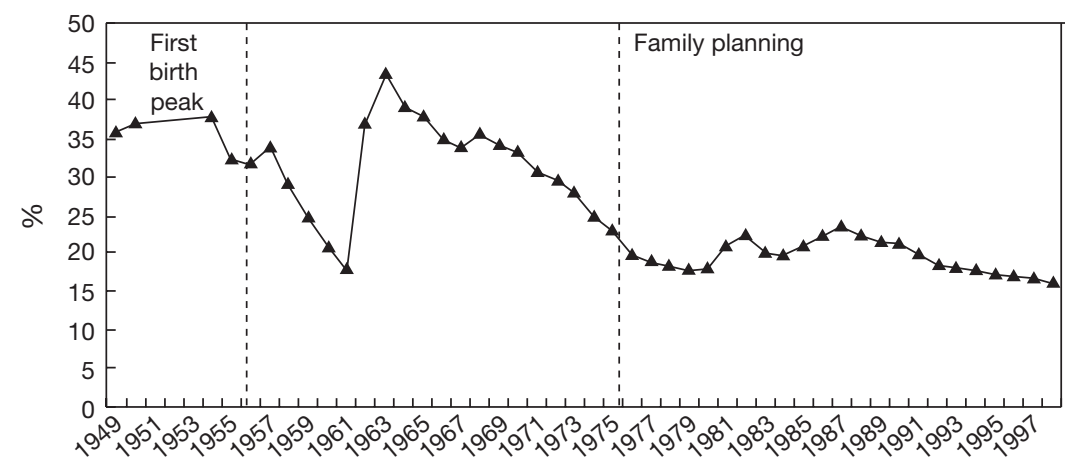

Figure 8.9 China's birth rate (1949-1997)

Source: Guojia tongjiju (National Bureau of Statistics), Renkou tongji nianjian (Population Statistical Yearbook 2000).

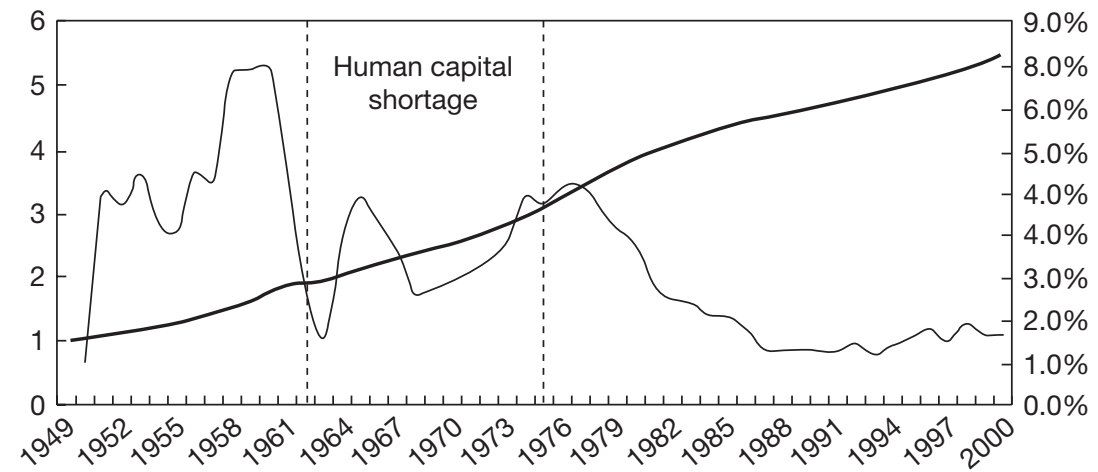

\section{- Per capita human capital reserve (year) \\ Per capita human capital reserve growth}

Figure 8.10 Trend of changes in per capita human capital (1949-2000)

Source: Master's dissertation by $\mathrm{Ch}$. Li, "Zhongguo ge diqu renli ziben yu jingji fazhan chaju yanjiu" (Research on Human Capital and Regional Disparities of Economic Development in China), School of Public Policy \& Management, Tsinghua University, 2001. 


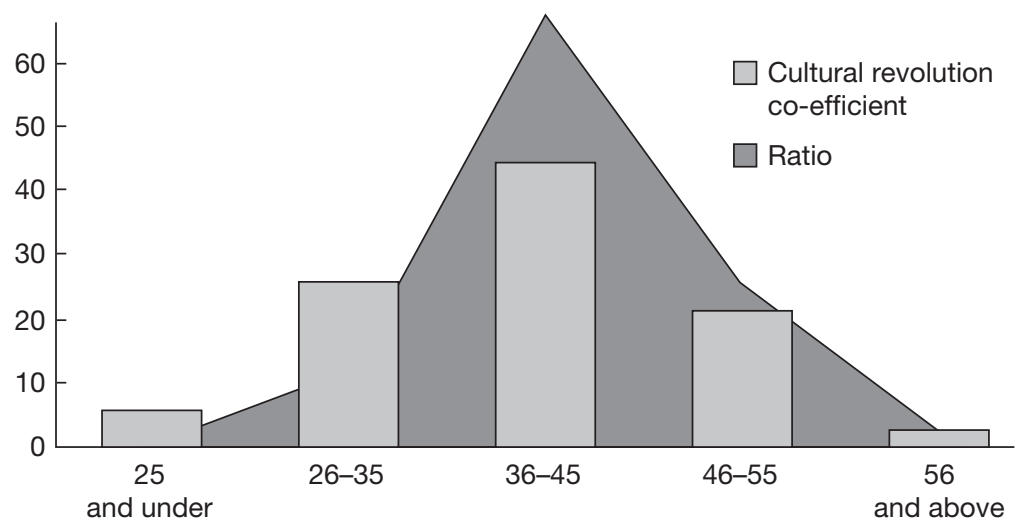

Figure 8.11 Proportion of laid-off workers in different age groups and their education experiences during the Cultural Revolution

Source: F. Cai (ed.), Zhongguo renkou yu laodong wenti baogao 2002 (China Population and Labor Report 2002), Beijing: Zhongguo shehui kexue wenxian chubanshe (Social Sciences Literature Publishing House), 2002.

\section{Develop human resources: reserve mechanisms and adaptation mechanisms for coping with an aging society}

Human resources usually refer to the sum total of knowledge, experience, skills and other intelligent abilities possessed by the population. Relative to the resource of labor, human resources place more stress on the quality of labor. Relative to simple physical labor, human resources place more stress on complicated mental activities. Studies of economic growth theories show that human resources may be regarded as a kind of capital, namely, human capital, which can improve labor productivity. It is an important source of economic growth. We argue that developing human resources should be a strategy of fundamental importance in taking up the challenges of the future aging population and stimulating long-term economic development.

First, developing human resources is a very effective "reserve mechanism" for coping with the future aging society. As mentioned earlier, the increase in the aged population means the rise of the social support coefficient and heavier social security burdens. In order to take up these challenges, society needs to boost production capacity and produce enough surplus to satisfy the consumption demand of the aging population. To intensify human capital investment now will store up human capital for future society and boost the production capacity for scores of years to come; it would inevitably become a powerful motive for economic growth. In fact, such means will exactly replace the decrease in labor by increasing human capital. This is an inevitable trend of economic development. Empirical study of China shows that China's economic growth pattern is undergoing a major shift from a type that relies on the quantity of labor to a 
type that relies on quality of labor. In the estimate of the sources of economic growth (1978-1995 and 1995-2001), the contribution of the number of the employed to economic growth dropped while that of human capital rose (see Table 8.1). From 1995 to 2001, the contribution by the number of the employed was already lower than human capital. At present, the growth in the number of laborers has dropped significantly and it will continue to drop in the next twenty years. In contrast, human capital has still maintained high growth and will become a major contributor to economic growth. So, developing human resources will be a fundamental guarantee for future sustainable economic growth and will stimulate economic structural changes. It will be an important means for coping with the pressure brought about by an aging population, especially after 2015 , when the working-age population will begin to drop rapidly. The next decade will be a fleeting opportunity for developing human resources and we must get a firm grasp of it.

Secondly, developing human resources is an "adaptation mechanism" for coping with an aging society. This requires analysis of the characteristics of human resources. Labor usually covers physical resources and mental resources, with the former as the main component. These two kinds of resources vary with work experience and the passing of time. Physical resources usually reach their highest point between the ages of 30 to 40 before going downward with the extension of labor time and age. That is to say, the depreciation rate for physical resources is very high over the time. When entering the old age stage,

Table 8.1 Estimate of the sources of economic growth (1978-2003)

\begin{tabular}{llc}
\hline & $1978-1995(\%)$ & $1995-2001(\%)$ \\
\hline Population & 1.4 & 0.9 \\
GDP & 9.8 & 8.2 \\
Per capita GDP & 8.4 & 7.3 \\
Employment & 2.6 & 1.2 \\
Labor productivity & 7.2 & 7.0 \\
Capital stock & 9.3 & 11.8 \\
Human capital & 2.2 & 2.8 \\
Capital productivity & 0.5 & -3.6 \\
Capital stock per labor & 6.7 & 10.6 \\
TFP (a) & $4.64(47.3)$ & $2.28(27.8)$ \\
TFP (b) & $3.95(40.3)$ & $1.30(15.9)$ \\
TFP (c) & $3.26(33.3)$ & $0.32(3.9)$ \\
\hline
\end{tabular}

Sources: J. Zheng and A. Hu, Zhongguo gaige shiqi shengji shengchanlu zengzhang bianhua de shizheng fenxi (1979-2001) (An Empirical Study of Productivity Changes among Provinces during China's Reform Period), Working paper No. 1, Center for China Study, Tsinghua University, 2004.

Note: In calculating TFP, (a) the weight of capital input is taken as 0.4 , that of labor input is taken as 0.3 , that of human capital input is taken as 0.3 ; (b) the weight of capital input is taken as 0.5 , that of labor input is taken as 0.25 , that of human capital input is taken as 0.25 ; (c) the weight of capital input is taken as 0.6 , that of labor input is taken as 0.2 , that of human capital input is taken as 0.2 . TFP in brackets is the contribution to GDP growth. 
physical decline is fast. But the mental resources reach their peak much later than physical resources. With the accumulation of experience, a laborer will become more skillful and good at solving problems. That is to say, mental resources have a relatively low "depreciation rate." In other words, people mainly relying on mental resources for a living could still maintain a very high productivity even in old age; their income will be much higher than those mainly relying on physical resources for a living and it is very late when their income begins to drop. They have a longer time for obtaining income and will be more capable of coping with economic pressures in old age. So, developing human resources has extended the effective working time and increased the life-long income and raised their capabilities of self-support. In terms of society as a whole, it means lowering the speed of "depreciation" of labor as a whole and better utilization of the production capacity of the old age group, thus reducing the pressure on society for supporting the aged. In this sense, developing human resources is an "adaptation mechanism" for easing the pressure of an aging population. This will promote and establish a new way of working and living compatible with an aging society and will also be a long-term measure for taking up the challenges of population aging.

In a word, to cope with an aging society by developing human resources is an important long-term strategy. For China, it will become even more urgent to develop human resources. As previously mentioned, the situation of population aging and its pressures on economic and social development in the next ten years will be stern because those people suffering most from lay-offs and unemployment now are those who are about to enter retirement and the old age stage around 2015. If we can develop the human resources among these people and enable them to get some income through re-employment, delaying their age for getting pensions, it would be useful for lightening the burdens of the current and future social pension funds. So, developing human resources is to develop the human resources of the entire nation and the human resources of both the future working-age population and the current on-the-job labor: to develop human resources among both young workers and the middle- and oldage groups. For the present, it is necessary to give particular attention to human development among the laid-off workers and the unemployed. If we miss the current ten-year opportunity for developing human resources, the pressure of population aging will delay the progress of China's future economic and social development.

\section{Life-long education and a learning system for human resources development}

To meet the development trend of future population aging and develop human resources of the entire population, the key lies in the establishment of a lifelong education and a human resources learning development system. This system should cover all the people and carry out education and training in different 
contents and forms according to the different characteristics of the population. Human resources is a concept that includes knowledge, skills, experience, and many other elements. The development of human resources should, therefore, be multi-angled and multi-leveled with the purpose of improving labor productivity and making people better live according to the requirements of their jobs rather than blindly pursue schooling and the breadth and depth of knowledge and skills. That is to say, people must be taught according to their aptitude. Apart from raising the stock of human resources according to social needs, developing human resources also includes the allocation and effective utilization of human resources. For the future laborers who are still studying at school, the emphasis of human resources development should be put on raising their knowledge and skills. School education should also serve the requirements of economic development and train people who are needed for economic development and should develop personnel reserves for future development. For the current laborers who are unemployed or laid off, the emphasis of human resources development should be put on raising human resources reserves while making a better allocation and use of human resources so as to enable them to meet the demand of an aging society and reduce the pressures on individuals and society.

In this system, the government is not necessarily the direct provider of educational products. It must play a role as promoter and pusher. For this purpose, the government must be well aware of the basic facilities and services necessary for education and training, giving full scope to the market mechanism to prevent market failure. For public goods with significant external costs and values and non-competitiveness, such as basic education, the government should play a role in providing the basic facilities and services. For competitive facilities and services (such as specialized training, professional quality training and so on), the government should open the market to non-governmental departments and private sectors and even to foreign investors in order to broaden the allocation of resources through market competition. The government may provide policy guidance to encourage citizens, non-governmental sectors and foreign organizations to participate, thus better ensuring supply of the services and more effectively satisfying the demand of citizens for skills and knowledge and more effectively developing human resources.

On this basis, we hold that the life-long education and learning system for human resources development to cope with population aging should cover the following areas.

First, to strengthen the basic education for young people by intensifying the basic functions and obligations of the government in compulsory education. By the end of the twentieth century, China had achieved nine-year compulsory education and eliminated illiteracy among young and middle-aged people. The length of education received per capita had reached eight years, well above the world average level. But no fundamental change has taken place in the situation in rural areas. At present, there are 431 counties that have not established 
nine-year compulsory education. Even places where compulsory education is widespread, the level is still very low and the foundation is feeble. In many places, students often drop out due to poverty. Teachers do not receive their wages in time, school houses have long been in disrepair and there are shortages in public expenses. In the life-long education system, compulsory education is a typical public good. "Every one enjoys compulsory education" - this is one of the most important functions of the government for providing public services. The Law of the People's Republic of China on Compulsory Education (1986) provides that "the state exempts tuition for students receiving compulsory education." So, it is necessary to introduce nine-year free compulsory education throughout the whole country and ban indiscriminate fee collection from students and their families. According to data provided by the Ministry of Education, at present the number of people receiving compulsory education in rural areas has reached 160 million and the main areas for spreading the nine-year compulsory education are rural areas and among rural people. The State Council has already decided to bring the rate of nine-year compulsory education up to more than 85 percent by 2007 in the economically less-developed western part of the country and bring the illiteracy rate among young and middle-aged people down to below 5 percent. According to the current national strength, China is entirely capable of providing aid to school-age children for compulsory education. Great efforts should be made to develop high schools (including regular senior secondary education, secondary vocational education, senior secondary professional school education and technical school education). In cities, the enrollment rate of graduates from junior secondary schools should be raised from about 60 percent at present to more than 75 percent by 2010 , and should make senior secondary school education widespread by 2015 . Rural areas should be encouraged to extend senior secondary education, bringing the enrollment rate of junior secondary graduates to 65 percent by 2010 and over 75 percent by 2015 and basically realize the objectives of senior secondary education in another five years. If we can achieve twelve-year education, the average educational level of people aged 10 and above would be raised from the current seven years to ten years and it would be raised from nine years to over twelve years in cities. The population burden would be likely to turn into human resources and increase potential productivity in the future.

Secondly, to establish and improve the continued education system for middleaged and young laborers (especially laborers of low quality, laid-off workers and the unemployed). The continuing education system should be centered on job training, including basic training for new workers before taking up their posts, advanced training for existing workers and training for those who shift their posts. The main purpose is to raise their professional levels and labor productivity. The continuing education system should also provide well-targeted job training for laborers who are temporarily out of jobs. For instance, people aged 40 and above who lack specialized skills should get training in home administration and services to enable them to turn their age disadvantages into 


\section{2}

advantages, thus putting human resources to their best use. The emphasis in human resources development among laid-off workers and the unemployed should be put on rational shift of posts by providing effective information, especially to those who specialize in certain skills and who are out of jobs due to economic restructuring. They should be encouraged to move in order to find proper posts by giving them some training. For laid-off workers and the unemployed, especially those who are about to enter the old age stage, human resources development would be especially pressing and will bring about gains in economic restructuring. For those who still have difficulty in taking up jobs, especially the typical old age groups, the government should provide them with basic living allowances and pension insurance through constructing a social safety net.

Thirdly, to carry out education and training among old age people to make full use of old age human resources. We have already mentioned that raising the level of human resources will extend the time for people to maintain their work efficiency. So, with the arrival of the aging society, old people will become major sources of human resources. It is necessary to pay attention to the development of human resources among old people and develop these resources by providing them with training and education. This part of human resources should be put to full use. First, it is necessary to extend the retirement age. The current retirement age was based on the life expectancy at the beginning of the founding of New China. But now, the mean life expectancy has risen from 49 in 1950 to about 71 at present. With the increase in life expectancy, the time used for work is comparatively shorter than with the previous generation of people, while the time for receiving pensions has been prolonged. This increases the pressure of supporting the aged population and wastes the human resources of the elderly who are still active (especially those who have a high level of knowledge and skills). We recommend that the current retirement age for women should be raised to 53 and 55 and those whose retirement age is set at 55 should be extended to 60 and 63; the retirement age for men should be extended to 63 . This will greatly ease the pressure on old age pension funds. Using the data of the fifth population census and related data, we calculate that if the retirement age for both men and women is extended to 63 , it would reduce the expenditure of basic old age pension funds annually by 80 billion Yuan, amounting to one-third of the total expenditure for a whole year. This shows that the extension of the retirement age would greatly ease the pressure on the social security system. However, the impact of this measure on employment is still to be calculated. Because of the differences in knowledge and experience of people of different age groups, the direct competition between the aged and young people for jobs is not very serious. It is necessary to strengthen guidance while introducing these measures in order to avoid adverse effects on employment. Further, it is necessary to change the age discriminatory standards for employing people. Support should be given to old people who have the experience, will and ability to seek re-employment. Old people should be organized to engage in community 
service, to give training and to offer policy and legal advice. For those engaged in science and technology and management, and technical people who are needed in their jobs, a policy of extending their appointment should be introduced. At the same time, it is necessary to establish a personnel market for old people so that old people who demand employment may try their hands at different jobs. In a word, developing and using old people as resources may lighten the burdens of the old age population and raise the living quality and confidence of the aged people. It is an inevitable option for the development of the future aging society. 


\section{China's urban unemployment and social security (1993-2000) ${ }^{1}$}

\section{Introduction}

Since the 1990s, China has entered a period of high unemployment accompanied by a massive structural adjustment of employment. Large numbers of jobs were cut in the formal sectors (urban state-owned and collective-owned units) and traditional industries, which caused large numbers of workers to lose their jobs or be relocated. At the same time, new formal sectors and informal sectors including individual and private enterprises have created large numbers of employment opportunities. China's employment is experiencing a process of "constructive destruction" that is characterized by the coexistence of construction and destruction, and the speed of construction is much slower than that of destruction. The unemployment explosion has caused great shocks to China's economic, social and political arenas. It has become the most serious developmental challenge for China in the first ten years of the new century.

There are different calculations regarding China's unemployed population. According to the National Statistical Bureau, there were 1.2 to 1.75 million urban registered unemployed, making the urban registered unemployment rate 2.9-3.1 percent. $^{2}$ At the same time, China's official agency, the Ministry of Labor and Social Security of China, admitted that there were 6 million laid-off workers from state-owned enterprises (SOEs). In fact, urban unemployment would further increase to about 10 million if the laid-off workers from the collectiveowned enterprises (COEs) were added. According to the new official definition of employed workers, ${ }^{3}$ employed workers decreased by 3.649 million in 2000 compared with that in 1999. The decrease in employment of SOEs and COEs was 30.77 million and 16.29 million respectively. The total number of employment decrease amounted to 47.06 million in $2000 .{ }^{4}$ Clearly, the registered unemployed no longer reflect the real situation of China's unemployment due to the massive decreased number of the employed population of SOEs and COEs.

What is the real situation of China's unemployment? Which sector, industry, region and social group is shocked most seriously by unemployment? What are the characteristics of the current unemployment in China? What are the economic, social and political effects caused by serious unemployment? This chapter will address these questions by analyzing statistical data. The chapter consists of seven parts. Part one introduces the analytical question. Part two 
estimates the urban unemployment population during the period 1993-2000. Part three analyzes the characteristics of China's unemployment such as educational level, age, sector distribution and regional distribution. Part four describes the characteristics of China's urban unemployment insurance. Part five analyzes the effects of unemployment using the Okun Model for the first time. Part six analyzes the changes in China's employment mode, including the relations between growth of employment and economic growth, regional differences of employment growth, development trends of formal and informal employment, and the background of the high unemployment. Part seven concludes the chapter and proposes policies that will help to solve the unemployment problem and reduce the unemployment rate.

\section{Estimates of China's urban unemployment (1993-2000)}

\section{Definitions of unemployment}

According to the International Labor Organization (ILO), the unemployed population includes those who have no job but have the ability to acquire employment and are now hunting for a job. This definition of unemployment includes both people who lose their job and those who give up work voluntarily. ${ }^{5}$ How many urban unemployed people are there in China today? Unfortunately, we cannot get an accurate estimate on this indicator using current statistical methods. The unemployment statistics of Guojia tongjiju (National Bureau of Statistics of China) include only registered unemployment and exclude the unemployed population of laid-off workers (xiagang) and the rural labor force who are working in urban areas. Therefore, the official estimate of unemployment is much lower than real urban unemployment. In order to correct these shortcomings, the chapter offers a new estimate of unemployment using various methods.

First, we define the major statistical definitions as follows (see Figure 9.1).

Registered unemployment refers to those who have non-agricultural residency (hukou) of a certain age (above 16 and below 50 for male and below 45 for female) with working ability and a desire to work and who have registered at the local employment agency for job search. ${ }^{6}$

Surveyed unemployment refers to the difference between total economically active population and the employed population in the sample estimation according to residency.

Laid-off unemployment refers to the total unemployed laid-off workers who cannot find re-employment and are out of work.

Farmer unemployment in urban areas refers to the unemployed population of rural laborers who have the ability to work but cannot find work opportunities in urban areas. Data of this kind of unemployment come from the investigation of the urban economically active population on the basis of the nature of residency. The number of unemployed farmers in urban areas is estimated on the ratio of the rural unemployed population to the total urban economically active population. 

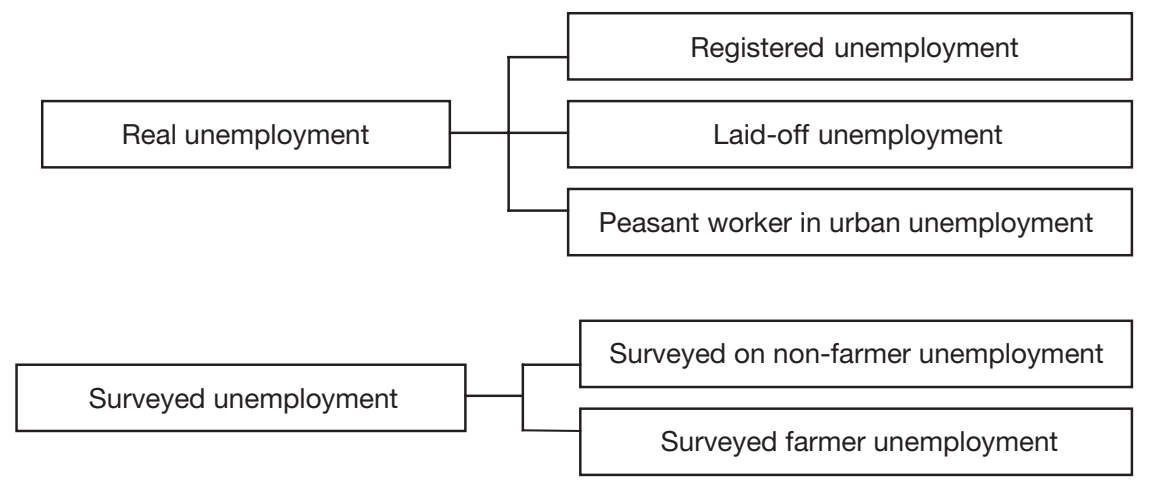

Figure 9.1 Definitions of unemployment

The real unemployment population includes the registered unemployed, unemployed laid-off workers and farmers unemployed in urban areas.

On the basis of the above definitions, we estimate the real unemployment of China through four different calibers: 1) caliber one for the surveyed unemployment rate is based on the composite calculation of the unemployment rate of the non-rural and rural residency economically active population; 2) caliber two for the surveyed unemployment rate is the unemployment rate of the nonrural residency economically active population; 3) caliber one for the real unemployment rate is the composite unemployment rate of the non-rural and rural residents in urban areas; 4) caliber two for the real unemployment rate is the unemployment rate of the non-rural residents in urban areas.

\section{Estimate of urban unemployment}

Based on the above definition and statistical standards, we can estimate China's real unemployment rate using the current statistical data. The results of the estimates are shown in Table 9.1, Table 9.2 and Table 9.3.

The characteristics of China's urban unemployment population are as follows.

First, China's urban registered unemployment increased by 5 percent annually since 1993 and amounted to 5.7 to 6 million in recent years. The registered unemployment and the registered unemployment rate cannot reflect the real situation of China's unemployment due to the rapid increase of real unemployment since 1996. In 1997, the registered unemployment only amounted to about 39 percent of the real unemployment and this ratio decreased to 35 percent in 2000.

Second, the surveyed unemployment in China increased substantially and amounted to 11 million. In 1997, the surveyed unemployment was 7.9 million and increased to 11.64 million in 1999 with an average annual increase rate of 10 percent and was nearly two times the registered unemployment population. 
Table 9.1 Estimates of real urban unemployment (1993-2000)

\begin{tabular}{lllllll}
\hline Year & $\begin{array}{l}\text { Unemploy- } \\
\text { ment } \\
\text { registered } \\
(10,000)\end{array}$ & $\begin{array}{l}\text { Unemploy- } \\
\text { sent } \\
\text { surveyed } \\
(10,000)\end{array}$ & $\begin{array}{l}\text { Laid-off } \\
(10,000)\end{array}$ & $\begin{array}{l}\text { Unemploy- } \\
\text { ment of } \\
\text { agricultural } \\
\text { work force } \\
(10,000)\end{array}$ & $\begin{array}{l}\text { Real } \\
\text { unemploy- } \\
\text { ment } \\
(10,000)\end{array}$ & $\begin{array}{l}\text { The ratio } \\
\text { of laid-off } \\
\text { and real } \\
\text { unemploy- } \\
\text { ment }(\%)\end{array}$ \\
\hline 1993 & 420 & - & $120-180$ & NA & $540-600 \mathrm{e}$ & $22.2-30.0$ \\
1994 & 476 & - & $144-216$ & NA & $620-692 \mathrm{e}$ & $23.2-31.2$ \\
1995 & 520 & 790 & $226-338$ & 55 & $800-913$ & $28.2-37.0$ \\
1996 & 553 & 815 & $356-535$ & 60 & $970-1148$ & $36.7-46.6$ \\
1997 & 570 & 980 & 815 & 88 & 1473 & 55.3 \\
1998 & 571 & 1194 & 877 & 93 & 1541 & 56.9 \\
1999 & 575 & 1164 & 937 & 106 & 1618 & 57.9 \\
2000 & 595 & - & 1000 & 100 & 1695 & 59.0 \\
\hline
\end{tabular}

Sources: Data for 1993 to 1996: A. Hu, "Xinshiji zuida tiaozhan: zhongguo jinru gaoshiye" (The Biggest Challenge in New Century: China Has Entered into the Stage of High Unemployment), Chira Study Report, Issue 48, June 1999.

Data for 1997: ibid. Unemployment in rural area data: Zhongguo laodong tongji nianjian 1998 (China Labor Statistical Yearbook 1998), 1998, p. 74.

Data for 1998 to 1999: Zhongguo laodong tongji nianjian 2000, pp. 7, 64 and 409; Zhongguo laodong tongji nianjian 1999, pp. 7 and 63; Zhongguo laodong tongji nianjian 1998, p. 74.

Data for 2000: A. Hu, "China's Employment Problems: Analysis and Solutions," China \& World Economy, 2001, No. 1, pp. 12-18.

Notes:

1. unemployment after 1998 refers to those who are unemployed and have not obtained a job;

2. unemployment in rural after 1997 is calculated through the spot check data based on "the structure of economic activity population in urban by group" from Zhongguo laodong tongji nianjian (China Labor Statistical Yearbook);

3. unemployment surveyed in 1998 and 1999 equals urban population in economic activity minus urban employment.

Third, China's urban unemployment population increased very rapidly and amounted to 17 million and more. According to the author's estimate, the real unemployment figures for China were 5.4 to 6 million and 14.73 million in 1993 and 1997 respectively. This number increased to 17 million in 2000 and was more than two times that of 1993 . The annual growth rate of real unemployment was 16 percent, which was not only higher than the economic growth but also hit the historical record.

Fourth, the unemployment of laid-off workers has become the main body of China's unemployment. In 1993, the unemployment of laid-off workers amounted to 1.2 to 1.8 million and increased to 8 million and 10 million in 1997 and 2000 respectively. The number of unemployed laid-off workers in 2000 was about 4.5 to 7.3 times that in 1993. The ratio of unemployed laidoff workers to the total real unemployment population increased from 28.2-37 percent in 1995 to 59 percent in 2000.

Fifth, the scale of farmer unemployment in urban areas remains small and stable and the unemployment rate is comparatively low. The total number of rural workers working in urban areas remained at less than 1 million and the unemployment rate was about 1.5 percent. $^{7}$ 
Table 9.2 Estimate of urban unemployment ratio (1995-2000)

\begin{tabular}{|c|c|c|c|c|c|}
\hline \multirow[t]{2}{*}{ Year } & \multirow{2}{*}{$\begin{array}{l}\text { Unemployment } \\
\text { registered }\end{array}$} & \multicolumn{2}{|c|}{ Unemployment surveyed } & \multicolumn{2}{|c|}{ Real unemployment } \\
\hline & & $\begin{array}{l}\text { Caliber one } \\
\text { (gross) }\end{array}$ & $\begin{array}{l}\text { Caliber two } \\
\text { (non-farmer) }\end{array}$ & $\begin{array}{l}\text { Caliber one } \\
\text { (gross) }\end{array}$ & $\begin{array}{l}\text { Caliber two } \\
\text { (non-farmer) }\end{array}$ \\
\hline 1995 & 2.9 & & & & \\
\hline 1996 & 3.0 & & & & \\
\hline 1997 & 3.1 & 4.9 & 6.1 & 7.3 & 7.5 \\
\hline 1998 & 3.1 & 5.8 & 7.8 & 7.5 & 7.9 \\
\hline 1999 & 3.1 & 5.5 & 7.4 & 7.6 & 8.2 \\
\hline 2000 & 3.1 & - & - & - & 8.3 \\
\hline
\end{tabular}

Sources: Guojia tongiju, Zhongguo laodong tongji nianjian 1998 (China Labour Statistical Yearbook), Beijing: Zhongguo tongji chubanshe (China Statistics Press), 1998, p. 74; Guojia tongjiju, Zhongguo laodong tongji nianjian 1999, p. 63; Guojia tongjiju, Zhongguo laodong tongji nianjian 2000, p. 64.

Notes:

1 Caliber one of the unemployment rates surveyed is the integrated inquisitional unemployment rate based on the urban economically active population and the rural economically active population according to the registered permanent residents; caliber two of the unemployment rate surveyed is based on the urban economically active population.

2 The real unemployment rate is the integrated inquisitional unemployment rate based on the agricultural population and the non-agricultural population according to registered permanent residents. It is calculated by the following way: real unemployment / unemployment surveyed times the unemployment rate surveyed (caliber one); caliber two of the unemployment rate is the unemployment rate of non-agricultural population, and it is calculated by the following way: the real unemployment minus the unemployment of peasants / the unemployment registered times the unemployment rate registered.

\section{Characteristics of the urban unemployment population}

\section{Characteristics of laid-off unemployed workers}

\section{Education structure}

Laid-off workers registered at the Reemployment Service Center show the following characteristics: workers with junior high school education or below form the main body of laid-off workers. In 1998 and 1999, the ratio of workers with junior high school education or below to the total of laid-off workers was 57 percent and 54.7 percent respectively.

\section{Age structure}

Laid-off workers registered at the Re-employment Service Center show the following age structure: workers aged above 35 account for the main body of the total laid-off workers. In 1999, laid-off workers aged between 35 to 46 years old amounted to 42.7 percent of the total laid-off workers and the laid-off workers above 35 years old amounted to 64.5 percent of the total laid-off workers. Obviously, there is a difference of age between registered unemployment workers 
Table 9.3 The real unemployment rate and real unemployment rate by region (1999) (10000 persons)

\begin{tabular}{|c|c|c|c|c|c|}
\hline Region & $\begin{array}{l}\text { Unemploy- } \\
\text { ment } \\
\text { registered } \\
\text { (a) }\end{array}$ & $\begin{array}{l}\text { Laid-off } \\
\text { (b) }\end{array}$ & $\begin{array}{l}\text { The real } \\
\text { unemploy- } \\
\text { ment }(d)\end{array}$ & $\begin{array}{l}\text { Registered } \\
\text { unemploy- } \\
\text { ment rate } \\
(\%)(a)\end{array}$ & $\begin{array}{l}\text { Real } \\
\text { unemploy- } \\
\text { ment rate } \\
(\%)(c)\end{array}$ \\
\hline Beijing & 2.5 & 14.0 & 16.5 & 0.6 & 4.0 \\
\hline Tianjin & 9.5 & 24.9 & 34.4 & 2.9 & 10.5 \\
\hline Hebei & 16.2 & 30.3 & 46.5 & 2.5 & 7.2 \\
\hline Shanxi & 9.5 & 22.3 & 31.8 & 2.1 & 7.0 \\
\hline Neimenggu & 12.4 & 15.2 & 27.6 & 3.1 & 6.9 \\
\hline Liaoning & 39.8 & 94.3 & 134.1 & 3.5 & 11.8 \\
\hline Jilin & 21.5 & 44.8 & 66.3 & 3.3 & 10.2 \\
\hline Heilongjiang & 24.1 & 71.9 & 96 & 2.5 & 10.0 \\
\hline Shanghai & 17.5 & 31.3 & 48.8 & 3.4 & 9.5 \\
\hline Jiangsu & 26.6 & 52.1 & 78.7 & 2.8 & 8.3 \\
\hline Zhejiang & 21.2 & 17.1 & 38.3 & 3.5 & 6.3 \\
\hline Anhui & 17.3 & 29.9 & 47.2 & 3.2 & 8.7 \\
\hline Fujian & 7.9 & 12.0 & 19.9 & 2.2 & 5.5 \\
\hline Jiangxi & 15.5 & 34.2 & 49.7 & 2.6 & 8.3 \\
\hline Shandong & 36.5 & 45.0 & 81.5 & 3.2 & 7.1 \\
\hline Henan & 22.0 & 43.2 & 65.2 & 2.6 & 7.7 \\
\hline Hubei & 33.1 & 56.7 & 89.8 & 3.3 & 9.0 \\
\hline Hunan & 30.7 & 52.6 & 83.3 & 3.9 & 10.6 \\
\hline Guangdong & 27.4 & 30.4 & 57.8 & 2.3 & 4.9 \\
\hline Guangxi & 11.6 & 13.4 & 25 & 3.3 & 7.1 \\
\hline Hainan & 3.7 & 5.4 & 9.1 & 3.2 & 7.9 \\
\hline Chongqing & 10.1 & 17.7 & 27.8 & 3.5 & 9.6 \\
\hline Sichuan & 29.6 & 39.1 & 68.7 & 3.7 & 8.6 \\
\hline Guizhou & 11.3 & 9.1 & 20.4 & 4.0 & 7.2 \\
\hline Yunnan & 6.2 & 7.2 & 13.4 & 2.5 & 5.4 \\
\hline Xizang & & 0.1 & 0.1 & & \\
\hline Shanxi & 10.7 & 24.9 & 35.6 & 2.6 & 8.7 \\
\hline Gansu & 8.0 & 9.4 & 17.4 & 2.8 & 6.1 \\
\hline Qinghai & 1.9 & 2.8 & 4.7 & 2.5 & 6.2 \\
\hline Ningxia & 3.7 & 2.4 & 6.1 & 4.5 & 7.4 \\
\hline Xinjiang & 10.3 & 8.2 & 18.5 & 3.7 & 6.6 \\
\hline
\end{tabular}

Sources:

(a) Data is from Zhongguo laodong tongji nianjian 2000 (China Labor Statistical Yearbook 2000), p. 86 .

Notes:

(b) It is estimated by author according to 40 percent of the number of urban laid-off workers;

(c) estimated by author according to the data surveyed by Guojia tongjiju (National Statistical Bureau), Zhongguo laodong tongji nianjian 2000, p. 64. The data by region are lacking;

(d) estimated by the author (the real unemployment rate equals the real unemployment / the unemployment registered / the unemployment rate registered), among which the real unemployment equals the unemployment registered plus laid-off staff plus the rural unemployment. 
and laid-off workers registered at the Reemployment Service Center. The main body of the registered unemployed is the workers below 35 years old and the ratio amounts to 63.9 percent.

\section{Laid-off workers increased rapidly}

The total laid-off workers in China increased from 8.9 million in 1996 to 21.54 million in 1999 with the growth rate at 142.7 percent.

The share of the laid-off workers in various economic units increased substantially

The share of the laid-off workers of the state-owned units (SOU) increased from 5.2 percent in 1996 to 13.84 percent in 1999. During the same period, the share of the collective-owned units (COU) increased from 9.7 percent to 36 percent and the share of other economic units increased from 3.3 percent to 11.63 percent.

\section{Main sources of laid-off workers}

State-owned enterprises (SOE) and state-owned loss-making enterprises (SOLME) are the main sources of laid-off workers. In 1998, laid-off workers from state-owned enterprises accounted for 67.8 percent of the total laid-off workers and this ratio was 47.2 percent for loss-making enterprises. In 1999, the share of laid-off workers from state-owned enterprises increased to 69.6 percent and the share for state-owned loss-making enterprises increased to 58.3 percent.

\section{Sectoral characteristics of laid-off workers}

The wholesale and retail trading sector, manufacturing industry, and mineral industry are the three major sectors affected most seriously by laid-off workers. In 1998, the share of laid-off workers amounted to 32.3 percent of the manufacturing sector, and the same ratio was 41.3 percent for the wholesale and retail sector and 21.6 percent for the mineral industry. The total number of laidoff workers in the above three sectors amounted to 17.25 million and accounted for 80 percent of total laid-off workers in China.

Banking and insurance, education, culture, radio, television and film, governmental agencies, party organizations, health and sports organizations as well as social welfare organizations have very low levels of laid-off workers (see Figure 9.2).

Laid-off workers mainly come from state-owned units and collectively-owned units in rural areas. The share of laid-off workers amounts to 85 percent higher or even to 100 percent in state-owned units and collectively-owned units. 
Sector

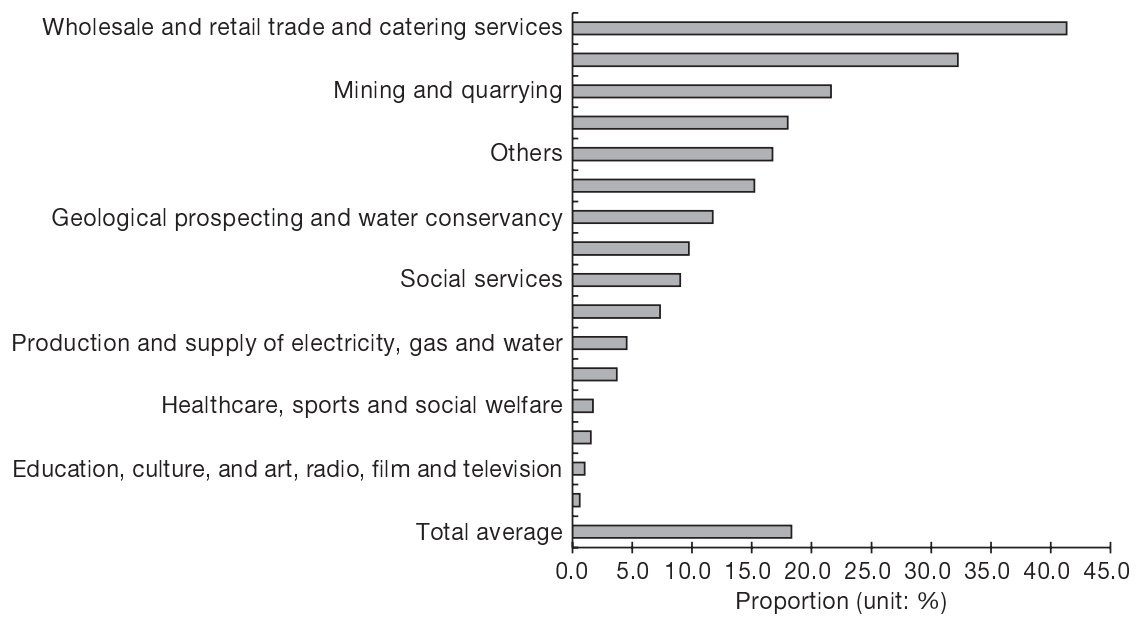

Figure 9.2 Proportion of laid-off workers by sector (1999)

\section{Regional characteristics of laid-off workers}

The problem of laid-off workers shows different characteristics across different regions due to great differences in the level of development and economic structure in China. The characteristics of laid-off workers of different regions in 1999 can be summarized as follows.

The real unemployment rate was very high in nearly every province and there were five provinces with real unemployment higher than 10 percent (see Table 9.3). These five provinces are Liaoning (11.8 percent), Hubei (10.6 percent), Tianjin (10.5 percent), Jilin (10.2 percent) and Heilongjiang (10.0 percent). At the same time, there were some provinces with a real unemployment rate lower than 6 percent. These provinces included Beijing ( 4.0 percent), Guangdong (4.9 percent), Yunnan (5.4 percent) and Fujian (5.5 percent).

There are eight provinces with more than 1 million laid-off workers and the unemployment situation in these provinces tends to be very serious. These provinces include Liaoning, Jilin, Heilongjiang, Jiangsu, Shandong, Henan, Hubei and Hunan. The total number of laid-off workers of these eight provinces amounts to 11.51 million. There are four provinces whose share of laid-off workers is higher than 30 percent, which include Tianjin (30.7 percent), Liaoning (37.3 percent), Jilin (31.8 percent) and Heilongiiang (31.3 percent).

In regions with the most serious unemployment situations, the share of laidoff workers of collective-owned units is very high, often higher than 60 percent. The share of laid-off workers of collectively-owned units in Liaoning province amounts to 80.47 percent. The number of this indicator was 70 percent for Jilin and 60 percent or higher for Hunan, Shanghai and Tianjin. 
The ratio of laid-off workers from state-owned loss-making enterprises to total local laid-off workers is higher than 50 percent for some provinces. This ratio was 83.8 percent, 61.8 percent and 50 percent for Qinghai, Gansu and Shaanxi respectively. The total of laid-off workers in Liaoning, Jilin, Heilongjiang, Hunan and Hubei amounts to 2.4 million and accounts for 44 percent of the total laidoff workers of this type.

The preceding analysis shows that the problem of laid-off workers and unemployment has become more and more serious in many provinces in China. The unemployment situation in old industrial bases such as northeast China and Hunan and Hubei provinces tended to deteriorate. Laid-off workers in these provinces account for a large share of the total unemployment in China. In addition, the problem of laid-off workers of loss-making enterprises has become more acute and the laid-off workers from loss-making enterprises become the main body of the unemployed in some provinces. The unemployment situation in southeastern coastal regions is relatively optimistic. As China's political and economic center, Beijing's unemployment situation has been effectively curbed. The problem of unemployment of laid-off workers in western China is relatively not serious. Generally speaking, the characteristics of laid-off workers and unemployment show great differences due to significantly different regional development models.

\section{Unemployment insurance}

China's unemployment insurance system only covers workers in formal sectors, with a coverage rate of no more than 50 percent. We have calculated the unemployment insurance on the basis of three different standards. The first one is the percentage of workers who have joined the unemployment insurance system compared to the total of formal workers. From 1994 to 1999, this ratio decreased at first and then increased to 83.7 percent in 1998. The second indicator is the percentage of the population who have joined the unemployment insurance system compared to the total urban employment population. This indicator also decreased first and then increased to 46.9 percent. The third indicator is the percentage of the population who have joined the unemployment insurance system compared to the total employment population in China. This share was only about 14 percent in 1999. This analysis shows that the unemployment coverage level of China is still very low, and the employed rural population as well as informal workers in urban areas are excluded from the unemployment insurance system. This means that the current unemployment insurance is actually beneficial only to a very small part of the population rather than to all members of society.

The coverage rate of illness and occupational injury insurance is very low. The percentage of workers who have joined the illness catastrophe insurance system (dabing tongchou) was only 1.8 percent in 1998 and increased slightly to 8.8 percent in 1999. The percentage of workers covered by the occupational injury insurance system was only 0.7 percent in 1993 and increased slightly to 
3.4 percent in 1999. The coverage rate of health insurance and labor injury insurance will be much lower if the urban informal workers were included. This shows that urban laborers still face high health insecurity (see Table 9.4).

The ratio of laid-off workers who have not acquired the basic living allowances amounted to 48.8 percent in 1997. This ratio decreased to 6.7 percent in 1999 due to the emergent measures adopted by the central government (see Figure 9.3). In 1996, the average annual living allowance received by laid-off workers was 925 Yuan and the monthly living allowance was 77 Yuan. The monthly living allowance was 47 Yuan for collective-owned units and 128 Yuan

Table 9.4 Coverage of medical and occupational injury insurance schemes in China (1993-1999)

\begin{tabular}{lllll}
\hline Year & \multicolumn{2}{l}{ Medical insurance } & \multicolumn{2}{l}{ Occupational injury insurance } \\
\cline { 2 - 5 } & $\begin{array}{l}\text { Contributors } \\
(10,000 \text { persons) }\end{array}$ & $\begin{array}{l}\text { Ratio to all } \\
\text { employees (\%) }\end{array}$ & $\begin{array}{l}\text { Contributors } \\
(10,000 \text { persons) }\end{array}$ & $\begin{array}{l}\text { Ratio to all } \\
\text { employee (\%) }\end{array}$ \\
\hline 1993 & 268 & 1.8 & 110 & 0.7 \\
1994 & 375 & 2.5 & 182 & 1.3 \\
1995 & 703 & 4.7 & 261 & 1.8 \\
1996 & 791 & 5.3 & 310 & 2.1 \\
1997 & 1082 & 7.4 & 351 & 2.4 \\
1998 & 1108 & 9.0 & 378 & 3.1 \\
1999 & 1040 & 8.8 & 396 & 3.4 \\
\hline
\end{tabular}

Sources: Guojia tongjiju, Zhongguo laodong tongji nianjian 2000, pp. 480-481; Zhongguo tongji nianjian 2000, p. 122.

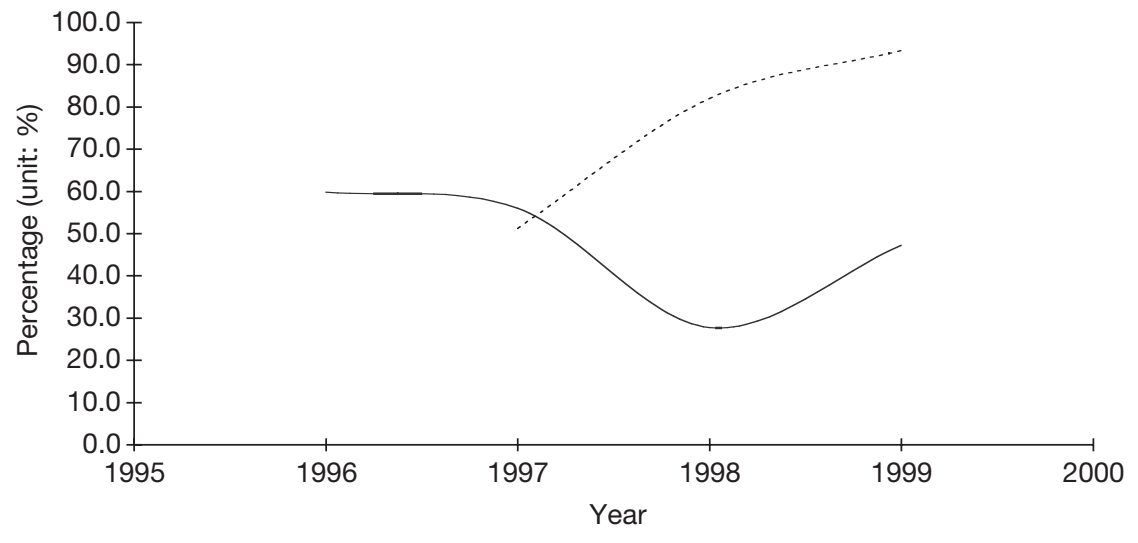

- The registered unemployed with relief

The laid-off unemployed with basic living allowance

Figure 9.3 Coverage of basic living allowance for laid-off workers and relief for the registered unemployed (1995-2000) 


\section{4}

for other units. In 1999, the average annual living allowance received by each laid-off worker was 1552 Yuan and the monthly living allowance per capita was 129 Yuan. The monthly living allowance per capita was 150 Yuan for state-owned units, 61 Yuan for collective-owned units and 181 Yuan for other units. In 1996, the ratio of the average living allowances received by laid-off workers was only about 14.9 percent of those of employed workers and this ratio slightly increased to 18.5 percent in 1999 .

The average living allowance received by laid-off workers in different regions varies significantly in China. In 1996, the average living allowance was 65 Yuan for Heilongjiang, 70 Yuan for Jilin, 76 Yuan for Liaoning, while this amount was much higher in political areas such as Tibet (437 Yuan) and Beijing (337 Yuan).

The ratio of the registered unemployed population who have not received unemployment allowance was 40.2 percent in 1996, which was around 2.22 million registered unemployed workers. This ratio increased to 52.8 percent in 1999. In 1996, the unemployment allowances received by registered unemployed workers amounted to only 7 percent of the wages of the employed population. In 1999, this ratio increased to 14.1 percent (see Table 9.5).

The preceding analysis shows that two very different social groups emerged: the winner (employment workers with increase income and insurance) and the loser (laid-off workers with no income and very low unemployment insurance compensation).

The ratio of the unemployment funds financed by the government to the total GDP is very low, though it has increased in recent years. The unemployment funds financed by the government consist of two parts: the first part used for the basic living allowances for laid-off workers and the second part used for unemployment insurance funds. The total funds amounted to 11 billion Yuan in 1996, and the former part occupied 75 percent and the latter occupied 25 percent of the total unemployment funds. In 1999, the total funds amounted to 41.5 billion Yuan and was about four times that in 1996, among which the basic living allowances occupied 77.9 percent and the unemployment insurance

Table 9.5 Coverage of urban unemployment insurance (1994-1999)

\begin{tabular}{lllll}
\hline Year & $\begin{array}{l}\text { Contributors } \\
(10,000 \\
\text { persons) }\end{array}$ & $\begin{array}{l}\text { Ratio to } \\
\text { all employees } \\
(\%)\end{array}$ & $\begin{array}{l}\text { Ratio to } \\
\text { employees } \\
\text { in urban (\%) }\end{array}$ & $\begin{array}{l}\text { Ratio to } \\
\text { gross } \\
\text { employment (\%) }\end{array}$ \\
\hline 1994 & 9500 & 64.0 & 51.6 & 14.1 \\
1995 & 9500 & 63.7 & 49.8 & 14.0 \\
1996 & 8333 & 56.1 & 42.1 & 12.1 \\
1997 & 7961 & 54.3 & 39.4 & 11.4 \\
1998 & 7928 & 64.3 & 38.3 & 11.3 \\
1999 & 9852 & 83.7 & 46.9 & 14.0 \\
\hline
\end{tabular}

Source: Guojia tongjiju, Zhongguo laodong tongji nianjian 2000, pp. 20, 480; Zhongguo tongji zhaiyao 2001, p. 40; Zhongguo tongji nianjian 2000, p. 54. 
funds accounted for 22.1 percent. The ratio of the total unemployment funds financed by the government to the total GDP amounted to only 0.16 percent in 1996 and 0.51 percent in 1999. The total unemployment funds financed by the government amounted to only 1.21 percent of the total wages of the employed workers throughout the country in 1996 and 4.2 percent in 1999 (see Table 9.6).

From the perspective of international comparison, China's unemployment insurance expenditure is way too low. According to the data from the UNDP, there were about 30 million unemployed workers in industrialized countries in 1997 with an unemployment rate of 7.7 percent. Also in 1997, the long-term unemployment rate was 28.9 percent for male workers and 25 percent for female workers. In these countries, the unemployment insurance funds accounted for over 1 percent of the total governmental expenditure and this ratio would be higher than 5 percent in countries with relatively higher unemployment rates. For example, the unemployment rate in Canada was 9.3 percent and its unemployment insurance funds were 8.1 percent of the total government expenditure. The two indicators were 10.5 percent and 6.3 percent for Ireland, 9.0 percent and 5.8 percent for Belgium, 20.9 percent and 7.0 percent for Spain, respectively (see Table 9.7). ${ }^{8}$

\section{The consequences of laid-off workers and unemployment}

Severe problems of laid-off workers and unemployment heavily affect the economic development and social stability of China, which make this one of the greatest challenges that China must face in the twenty-first century. Serious outcomes from these problems will be felt in every aspect of the Chinese people's lives.

Table 9.6 Investment in security for laid-off and unemployed (1996-1999)

\begin{tabular}{|c|c|c|c|c|c|c|}
\hline Year & $\begin{array}{l}\text { Total } \\
\text { amount of } \\
\text { the basic } \\
\text { alimony } \\
\text { (10 } 0^{8} \text { Yuan) }\end{array}$ & $\begin{array}{l}\text { Total } \\
\text { amount of } \\
\text { security } \\
\text { for unem- } \\
\text { ployment } \\
\text { (10 } 0^{8} \text { Yuan) }\end{array}$ & Total & $\begin{array}{l}\text { Ratio } \\
\text { between } \\
\text { the capital } \\
\text { for unem- } \\
\text { ployment } \\
\text { and the } \\
\text { expenditure } \\
\text { of govern- } \\
\text { ment (\%) }\end{array}$ & $\begin{array}{l}\text { Ratio } \\
\text { between the } \\
\text { capital for } \\
\text { unemploy- } \\
\text { ment and } \\
\text { the total } \\
\text { amount of } \\
\text { wage (\%) }\end{array}$ & $\begin{array}{l}\text { Ratio } \\
\text { between } \\
\text { the capital } \\
\text { for unem- } \\
\text { ployment } \\
\text { and GDP } \\
(\%)\end{array}$ \\
\hline 1996 & 82.50 & 27.29 & 109.79 & 1.38 & 1.21 & 0.162 \\
\hline 1997 & 142.37 & 36.33 & 178.7 & 1.94 & 1.90 & 0.240 \\
\hline 1998 & 238.88 & 47.41 & 286.29 & 2.65 & 3.08 & 0.365 \\
\hline 1999 & 323.56 & 91.61 & 415.17 & 3.15 & 4.20 & 0.507 \\
\hline
\end{tabular}

Sources: Guojia tongjiju, Zhongguo laodong tongji nianjian 2000, pp. 5, 178, 485; Zhongguo laodong tongji nianjian 1999, pp. 205, 522, 533; Zhongguo laodong tongji nianjian 1998, p. 230; Zhongguo laodong tongji nianjian 1997, p. 213; Zhongguo tongji zhaiyao 2001, pp. 16, 43, 66. 
Table 9.7 Unemployment and unemployment insurance in industrialized countries

\begin{tabular}{|c|c|c|c|c|c|c|c|}
\hline & \multirow{2}{*}{$\begin{array}{l}\text { Unem- } \\
\text { ployment } \\
(1,000) \\
1997\end{array}$} & \multirow{2}{*}{$\begin{array}{l}\text { Gross } \\
\text { unemploy- } \\
\text { ment ratio } \\
\text { (\%) } 1997\end{array}$} & \multicolumn{2}{|c|}{$\begin{array}{l}\text { The ratio in long } \\
\text { term (percent) }\end{array}$} & \multirow[t]{2}{*}{$\begin{array}{l}\text { Voluntary } \\
\text { (\%) } 1993\end{array}$} & \multirow{2}{*}{$\begin{array}{l}\text { Involuntary } \\
\text { part-time } \\
\text { (\%) } 1993\end{array}$} & \multirow{2}{*}{$\begin{array}{l}\text { Unem- } \\
\text { ployment } \\
\text { alms } \\
\text { GDP (\%) } \\
1991\end{array}$} \\
\hline & & & $\begin{array}{l}\text { Female } \\
\text { (1997) }\end{array}$ & $\begin{array}{l}\text { Male } \\
\text { (1997) }\end{array}$ & & & \\
\hline Canada & 1414 & 9.3 & 10.2 & 14.5 & 0.9 & 5.5 & 8.1 \\
\hline Norway & 93 & 4.1 & 11.1 & 14.0 & 1.2 & & 2.2 \\
\hline US & 6739 & 5.0 & 8.0 & 9.4 & 0.9 & 5.0 & 1.5 \\
\hline Japan & 2300 & 3.5 & 11.8 & 28.8 & 2.2 & 1.9 & 0.7 \\
\hline Belgium & 375 & 9.0 & 61.5 & 59.4 & 1.5 & 3.8 & 5.8 \\
\hline Sweden & 367 & 8.0 & 26.9 & 31.8 & 2.0 & 6.2 & 0.8 \\
\hline Australia & 791 & 8.5 & 27.5 & 33.1 & 1.6 & 6.9 & 4.0 \\
\hline Netherlands & 422 & 5.6 & 48.5 & 49.9 & 0.6 & 5.6 & 4.5 \\
\hline UK & 2034 & 7.1 & 27.8 & 44.9 & 0.6 & 3.2 & 1.7 \\
\hline France & 3192 & 12.4 & 43.3 & 39.1 & 0.2 & 4.8 & 3.2 \\
\hline Switzerland & 162 & 4.2 & 32.8 & 25.5 & & & 0.4 \\
\hline Finland & 367 & 14.5 & 28.2 & 33.9 & 1.5 & 2.9 & 3.6 \\
\hline Germany & 4308 & 9.8 & & & & 1.5 & 3.0 \\
\hline Denmark & 174 & 5.4 & 27.9 & 26.3 & 1.6 & 4.8 & 5.5 \\
\hline Austria & 165 & 5.2 & 28.4 & 28.9 & & & 1.8 \\
\hline Italy & 2805 & 12.5 & 66.2 & 66.5 & 2.6 & 2.3 & 1.0 \\
\hline Ireland & 159 & 10.5 & 46.9 & 63.3 & 0.5 & 3.3 & 6.3 \\
\hline Spain & 3357 & 20.9 & 60.4 & 49.9 & 0.2 & 1.0 & 7.0 \\
\hline $\begin{array}{l}\text { Industrialized } \\
\text { countries } \\
\text { in total }\end{array}$ & 29974 & 7.7 & 25.0 & 28.9 & & & \\
\hline
\end{tabular}

Source: UNDP, Human Development Report 1999, p. 215.

\section{Economic consequences}

According to the estimate of the Okun Model, the gap between real economic output and potential output caused by urban unemployment is increasing and its ratio to GDP is rising. To calculate the economic cost of laid-off workers by applying the Okun Model, we can make the following hypotheses.

Hypothesis 1: we must replace the nation-wide comprehensive (including rural areas) unemployment rate with a constructed real urban unemployment rate. ${ }^{9}$

Hypothesis 2: the natural unemployment rate of China is 5 percent.

Hypothesis 3: according to the estimate of the Okun Model, if the real unemployment rate is higher than the natural unemployment rate by 1 percent, the economic cost in GDP would be 2.25 percent, that is, "a" in the Model equals 2.25.

Thus, we can estimate the economic consequences of lay-offs and unemployment (see Table 9.8). According to the calculations of Table 9.8, the economic cost caused by severe lay-offs and unemployment is up to 6 percent.

We can draw the conclusion that to decrease personnel and increase efficiency by lay-offs and labor redistribution (fenliu) can improve the operational efficiency of economic units at the micro-level, but leads to greater losses at 
Table 9.8 The economic costs of lay-offs and unemployment (1997-2000) (\%)

\begin{tabular}{llll}
\hline Year & $\begin{array}{l}\text { Growth rate of } \\
\text { GDP }\end{array}$ & $\begin{array}{l}\text { Real unemployment } \\
\text { rate (caliber one) }\end{array}$ & $\begin{array}{l}\text { Ratio between the } \\
\text { economic cost and GDP }\end{array}$ \\
\hline 1997 & 8.6 & $7.3-7.5$ & $5.2-5.6$ \\
1998 & 7.8 & $7.5-7.9$ & $5.6-5.7$ \\
1999 & 7.1 & $7.6-8.2$ & $5.9-7.2$ \\
2000 & 8.0 & 8.3 & 7.4 \\
\hline
\end{tabular}

Sources: Guojia tongjiju (National Bureau of Statistics of China), Zhongguo tongji nianjian 2000 (Chinese Statistical Yearbook 2000), Beijing: Zhongguo tongji chubhanshe (China Statistics Press), 2000, p. 54.

the macro-level. To solve the redundant personnel problem only by lay-offs and labor redistribution is a questionable approach. Its effects should be further weighed.

\section{Social consequences}

The problems of lay-offs and unemployment directly affect up to one-eighth of China's urban inhabitants. In 2000, the number of real unemployment in China was 16.95 million. If we estimate that each urban family has 3.3 members and each family has one laid-off member, then about 56 million people, that is 12.2 percent of the total urban inhabitants, have been directly affected by lay-offs and unemployment. Unemployment severely affects the social stability of China.

The legal cases of labor disputes increased substantially. The number of accepted cases and subsequent hearings increased from 47,951 in 1996 to 120,191 in 1999, among which the number of collective labor dispute cases increased from 3,150 to 9,043 , the number of lodgment and prosecution increased from 1,389 to 3,903 for the same period. In terms of sector structure, the labor dispute frequency in foreign, Hong Kong, Macao and Taiwan invested enterprises is the highest, 45.5 cases occurred in every 10,000 workers in 1999, much higher than other economic units; in terms of appeal subject, the proportion of individual appeal cases was 87.5 percent, and the proportion of collective appeal cases was 7.5 percent, the proportion of cases appealed by the employment units is 87.5 percent, so the employees are the main victims of labor disputes. ${ }^{10}$

\section{Political consequences}

Ordinary people have extremely strong feelings of insecurity regarding social and political stability. According to a sample survey in six large cities by the Academy of Macroeconomic Research, SDPC Source, when ordinary people were asked to choose the factors that affect social stability, lay-offs and unemployment was the third most important factor in 1998, the second factor in 1999 


\section{8}

Economic and social transformation in China

and the first factor in 2000 (see Table 9.9). According to another sample survey, the proportion of inhabitants who feel heavy pressure and severe insecurity has been rising since 1995, from 65.4 percent in 1995 to 83.5 percent in 1999 (see Figure 9.4). The severe problems of lay-offs and unemployment are a heavy charge on the mental endurance of common people, and severely threaten social order in China.

Table 9.9 Change in the top five most important social problems concerning common people (1998-2000)

\begin{tabular}{llllll}
\hline Year & First & Second & Third & Fourth & Fifth \\
\hline 1998 & $\begin{array}{l}\text { The } \\
\text { emergence } \\
\text { of corruption }\end{array}$ & $\begin{array}{l}\text { The income } \\
\text { gap }\end{array}$ & $\begin{array}{l}\text { The } \\
\text { increment in } \\
\text { unemployment }\end{array}$ & $\begin{array}{l}\text { Overburden } \\
\text { of the } \\
\text { peasants }\end{array}$ & $\begin{array}{l}\text { The basic level } \\
\text { organization } \\
\text { of CCP lacks } \\
\text { capability of } \\
\text { governance }\end{array}$ \\
$1999 \begin{array}{l}\text { Corruption } \\
\text { of officers }\end{array}$ & $\begin{array}{l}\text { The } \\
\text { increasing of } \\
\text { demission } \\
\text { and } \\
\text { unemployment }\end{array}$ & $\begin{array}{l}\text { The } \\
\text { increasing } \\
\text { income gap }\end{array}$ & $\begin{array}{l}\text { The } \\
\text { deterioration } \\
\text { of public } \\
\text { security }\end{array}$ & $\begin{array}{l}\text { The basic level } \\
\text { organization } \\
\text { of CCP lacks } \\
\text { capability of } \\
\text { governance }\end{array}$ \\
& $\begin{array}{l}\text { Severe } \\
\text { corruption }\end{array}$ & $\begin{array}{l}\text { Wide gap } \\
\text { between the } \\
\text { rich and the } \\
\text { poor }\end{array}$ & $\begin{array}{l}\text { The } \\
\text { deterioration } \\
\text { of public } \\
\text { security } \\
\text { increasing } \\
\text { of lay-offs } \\
\text { and } \\
\text { unemployment }\end{array}$ & $\begin{array}{l}\text { Mand selling fake } \\
\text { goods }\end{array}$ & \\
\hline
\end{tabular}

Source: A sample survey on six big cities by Academy of Macroeconomic Research, SDPC (2001).

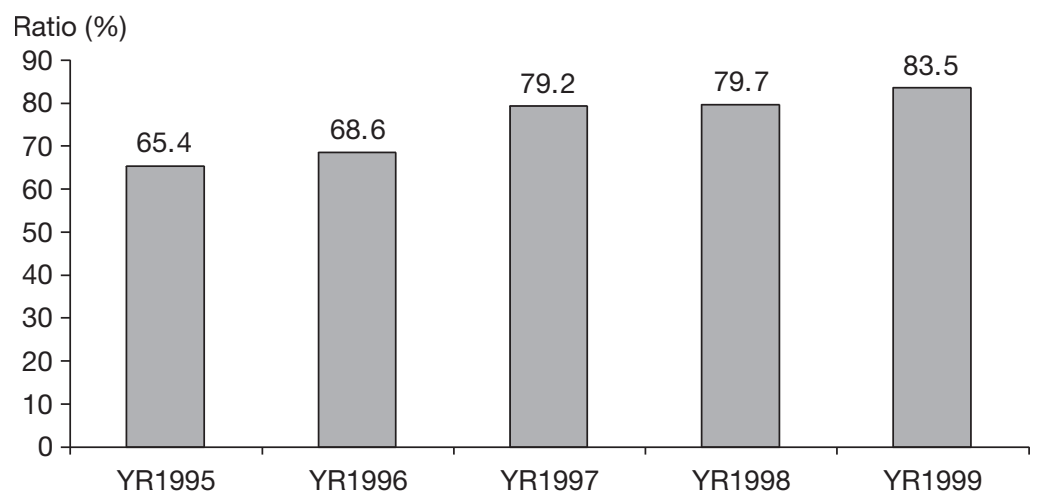

Figure 9.4 Ratio of ordinary people who feel a high level of pressure in life

Source: Sh. Wang, "Kaifangxing, fenpeixing chongtu he shehui baozhang: zhongguo jiaru WTO de shehui he zhengzhi yingxiang" (Open and Distribution Conflicts and Social Security: The Social and Political Impacts of China's Accession to WTO), 2001. Available at http://www.xslx.com/ article1/messages $02 / 2250 . h t m l$ (accessed July 10, 2005). 
The increase in lay-offs and unemployment directly threatens the political stability of China. Collective protest rallies, such as sit-downs and demonstrations, which occur frequently in some regions, are good examples.

Severe lay-offs and unemployment problems have put great pressure on the government. Ever-increasing lay-offs and unemployment will affect the social stability of China. The Chinese government has been paying more attention to laid-off and unemployed workers and has set up certain compensation mechanisms. It can be perceived that severe social problems caused by lay-offs and unemployment have forced the Chinese government to push for reforms of the social insurance system and to accelerate social change.

\section{Change in employment patterns: from formal employment to informal employment}

\section{Change in the relation between economic development and employment increase: from high economic growth with high employment increase to high economic growth with low employment increase}

There are four patterns in the relation between the economic growth rate and the employment increase rate. The first pattern is high economic growth and high employment increase. The second pattern is high economic growth but low employment increase or no employment increase. The third pattern is low economic growth and low employment increase. The forth pattern is low economic growth but high employment increase. Since 1980, the Chinese economy has entered the takeoff period with high-speed economic growth and increased employment opportunities. During the Seventh Five-Year Plan Period, the average annual employment increase rate reached 5.08 percent, that is, as GDP increased by 1 percent, the employment rate increased by 0.643 percent accordingly, showing the characteristics of high economic development and high employment increase. During the Eighth Five-Year Plan Period, the average annual employment increase rate decreased to 1.23 percent, which means, as GDP increased by 1 percent, the employment rate increased by 0.106 percent accordingly, showing the characteristics of high economic development and low employment increase. It can be seen that high economic development does not necessarily lead to more employment opportunities. High capital investment does not always result in a high employment increase either. From 1986 to 1995, the average annual increase rate of investment in fixed assets rose from 16.5 percent to 36.9 percent, but the elasticity of employment to fixed assets investment decreased from 0.308 to 0.033 . In conclusion, the contributory effects of economic growth or capital accumulation on employment depend on the development policies and industrialized technical guidelines. From the economics point of view, if we wish to create more employment opportunities under the presupposition of maintaining a higher economic growth rate and capital investment rate, we must promote the elasticity of employment. We should especially devote major efforts to develop the tertiary industry because the elasticity of employment increase in the tertiary 
industry is the highest. As its additional values increase by 1 percent in the tertiary industry, employment will increase by 0.722 percent. In comparison, as additional values increase by 1 percent in the secondary industry, employment can only increase by 0.182 percent (see Table 9.10).

\section{Change in employment patterns: from formal employment to informal employment}

At present, China is at a critical stage of economic transformation. The readjustment of the employment structure is the key component and aim of economic restructuring, and accordingly a change in employment models is the main component of the readjustment of the employment structure. Economic structure regulation and employment structure readjustment correlate and interact with each other. Yet, China's present transformation of employment models falls gravely behind economic restructuring, and the direction of employment pattern transformation is now confused, which leads to the deterioration of employment conditions.

There are three basic directions in China's present economic restructuring: the "marketization" of the economic operation mechanism; the "non-nationalization" of ownership structure; and the "open economy" under the condition of economic globalization. The three directions form a development process characterized by correlation, interaction and mutual promotion. Under such conditions, how do we determine the basic direction of China's employment pattern transformation?

Under the macroscopic background of economic restructuring, the conditions that China's employment structure readjustments face are as follows. The first factor is industrial structure, that is, agriculture, the traditional mining and quarrying industry, the manufacturing industry and the construction industry have transformed quickly from enormous labor absorption to enormous labor rejection, and

Table 9.10 Calculation of employment elasticity (1986-2000)

\begin{tabular}{llll}
\hline Item & $\begin{array}{l}\text { Seventh } \\
\text { Five-Year } \\
\text { Plan Period } \\
(1986-1990)\end{array}$ & $\begin{array}{l}\text { Eight } \\
\text { Five-Year } \\
\text { Plan Period } \\
(1991-1995)\end{array}$ & $\begin{array}{l}\text { Ninth } \\
\text { Plan Pear } \\
(1996-2000)\end{array}$ \\
\hline $\begin{array}{l}\text { Annual growth rate of GDP (\%) (a) } \\
\text { Annual growth rate of investment in } \\
\quad \text { fixed assets (\%) (b) }\end{array}$ & 7.9 & 12.0 & 8.3 \\
$\begin{array}{l}\text { Annual growth rate of employment (\%) } \\
\quad(\mathrm{c})\end{array}$ & 5.08 & 36.9 & 11.2 \\
$\begin{array}{l}\text { The employment elasticity of economic } \\
\text { growth (c/a) }\end{array}$ & 0.643 & 0.106 & 0.93 \\
$\begin{array}{l}\text { The employment elasticity of investment } \\
\text { in fixed assets (c/b) }\end{array}$ & 0.308 & 0.033 & 0.083 \\
\hline
\end{tabular}

Source: Guojia tongjiju, Zhongguo tongji nianjian 2000, pp. 7, 9, 19, and 40. 
become the main sources of lay-offs and unemployment. The second factor is the deep contradiction in economic operation that the state-owned industries generally face a deficit. The third factor is technological progress, which causes enormous cuts to traditional jobs and creates new jobs, thus steps up the structural readjustment of employment. The fourth factor is the transformation to a market economy; employment in state-owned economy shrinks swiftly, while the nonstate-owned economy lags behind in development, leading to a rapid increase in unemployment. The fifth factor is capital deepening; since China undertakes the industrialization technical guideline of capital concentration, the effect of investment on employment increase is therefore limited. ${ }^{11}$

Against the background of employment structural adjustment, China's employment model transformation is in the process of "informalization - formalization - informalization." At the very beginning of the establishment of the People's Republic of China, the informal economy dominated and employment in individual and privately owned economies was the main employment pattern. During the nationalization period, China's economy entered into the planned economy period. Traditionally formal sectors (such as state-owned and collective-owned units) monopolized China's national economy and enrolled almost all employees. During the transition period, China began to set up a market economy system, and the employment structure started to change dramatically. The ratio of traditionally formal sectors in the employment structure decreased rapidly, the ratio of newly emerging formal sectors (such as joint ventures, cooperative enterprises and foreign invested enterprises, joint stock companies) in the employment structure increased swiftly, and informal employment began to emerge. Employment in traditionally formal sectors is very large, and its decrease has been rapid; yet the development of newly emerging formal and informal sectors falls behind. Accordingly, the newly emerging economic sectors cannot recruit labor from the traditional formal sectors, which leads to an increase in unemployment. In the later period of economic transition, a comparatively complete market economy system is to be set up; the readjustment of employment models enters a stable stage. During this period, the ratio of traditional and formal sectors in employment decreases to a lower level, while newly emerging formal sectors enter the mature stage of development and recruit large numbers of laborers; informal sectors enter a stable development stage and become one of the main channels for urban employment; a balance between supply and demand in the labor market can generally be reached, as unemployment decreases but is still maintained at a high level (see Figure 9.5). As for the backgrounds and characteristics of the transformation of employment models in different periods, please refer to Table 9.11).

We can see from Figure 9.5 and Figure 9.6 that China now is at the medium period of transition. The economic restructuring is entering the stage of rapid deepening, the scale of unemployment is at its peak, and the unemployment rate will maintain a much higher level in the next few years. Speeding up restructuring and the development of newly emerging formal sectors (especially the rapid development of informal sectors) have a direct bearing on the future 


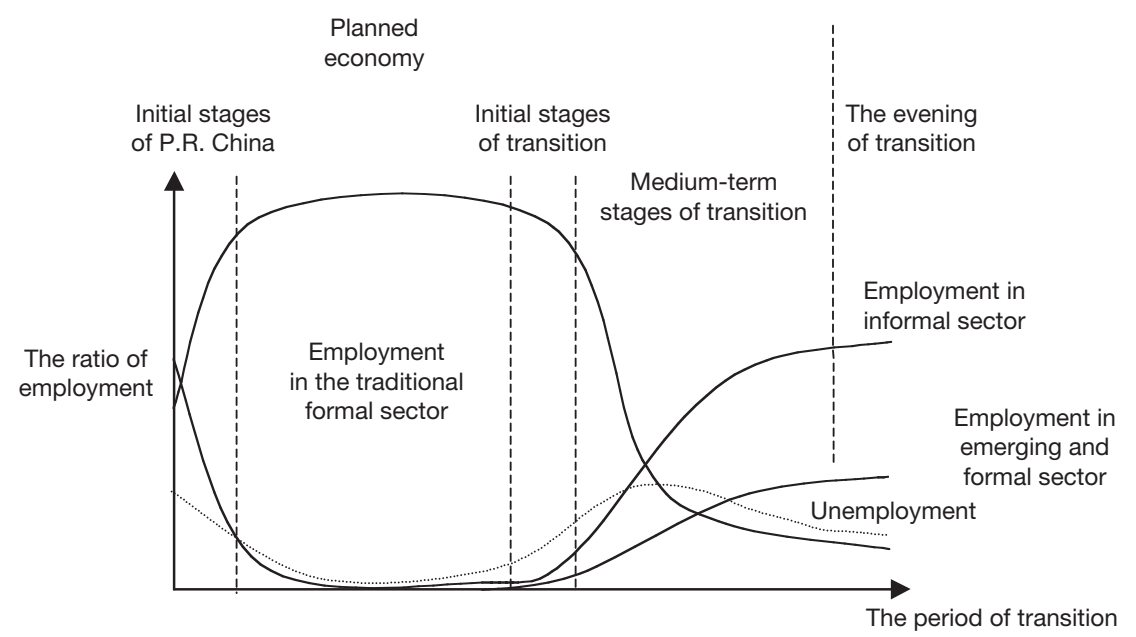

Figure 9.5 Employment trends for various sectors

of unemployment in China. We estimate that the unemployment peak will last for three to five years with a prolonged restructuring process. The number of unemployed people will decrease, though it will remain at a comparatively high level in the near future.

During the Ninth Five-Year Plan Period, the characteristics of the changes in urban formal and informal employment were as follows (see Figure 9.6).

First, the ratio of formal sectors in employment decreased substantially but still maintained a comparatively high level. The ratio of urban employees to the total formal employment decreased from 78.1 percent in 1995 to 52.9 percent in 2000 .

Secondly, as for the formal sectors, employees in traditionally formal sectors (state-owned and collective units) decreased substantially, 44.3 million jobs have been cut, and its ratio to total employment decreased from 73.5 percent in 1995 to 45.1 percent in 2000 . The ratio of newly emerging formal sectors in employment increased from 4.6 percent in 1995 to 9.3 percent in 2000 . The ratio of formal sectors in employment will decrease further, within which the ratio of newly emerging formal sectors will increase.

Thirdly, the most substantial decrease of employees occurred in the three traditional industries, that is, the mining and quarrying industry, the manufacturing industry and the construction industry. In nationwide urban employment, employees in the manufacturing industry decreased by 19.43 million or by a proportion of 35.7 percent; employees in the construction industry decreased by 2.75 million or by a proportion of 26.1 percent; employees in the mining and quarrying industry decreased by 2.64 million or by a proportion of 28.9 percent. In total, employees in the three industries decreased by 24.82 million, about 79.2 percent of the overall decrease in employees. 


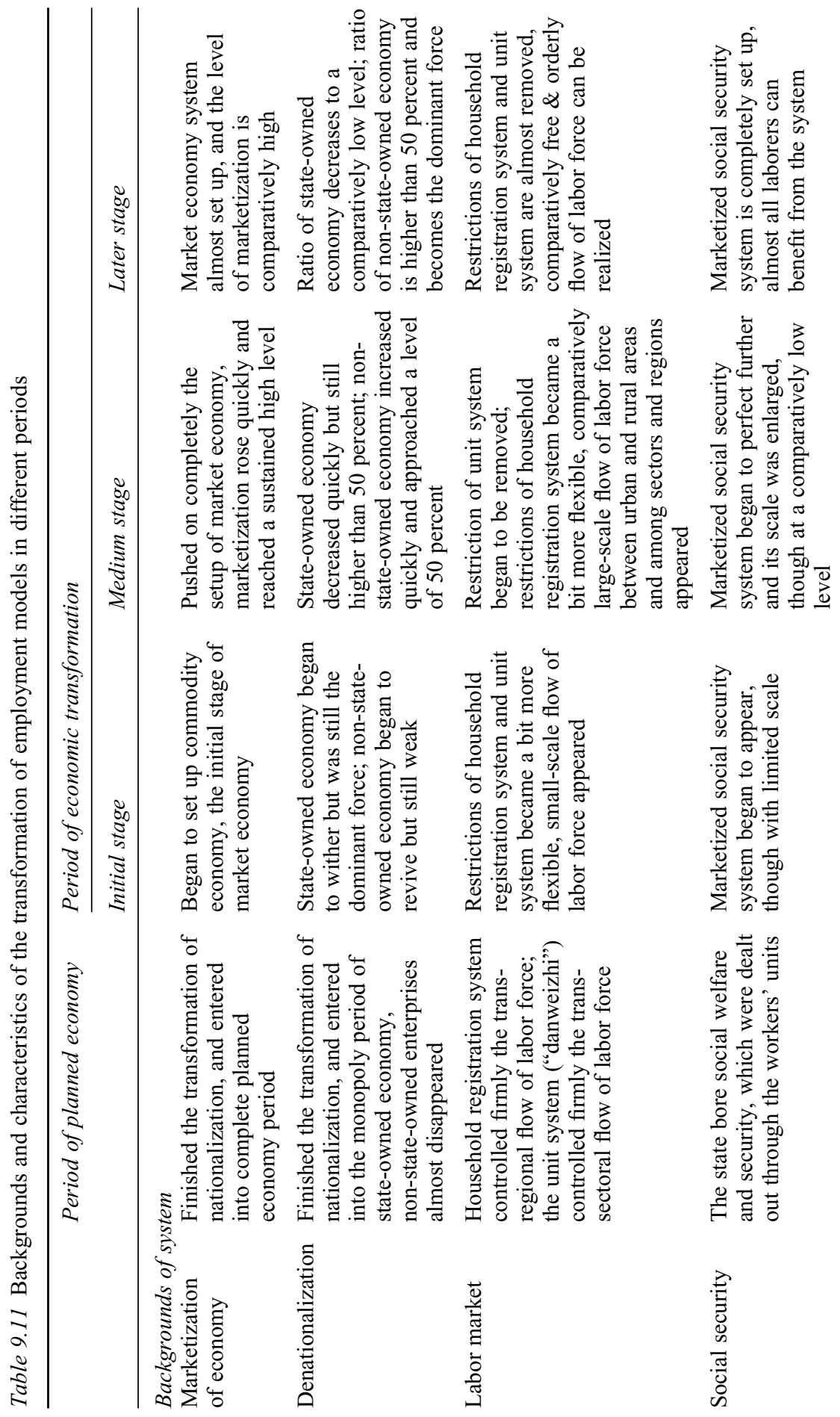




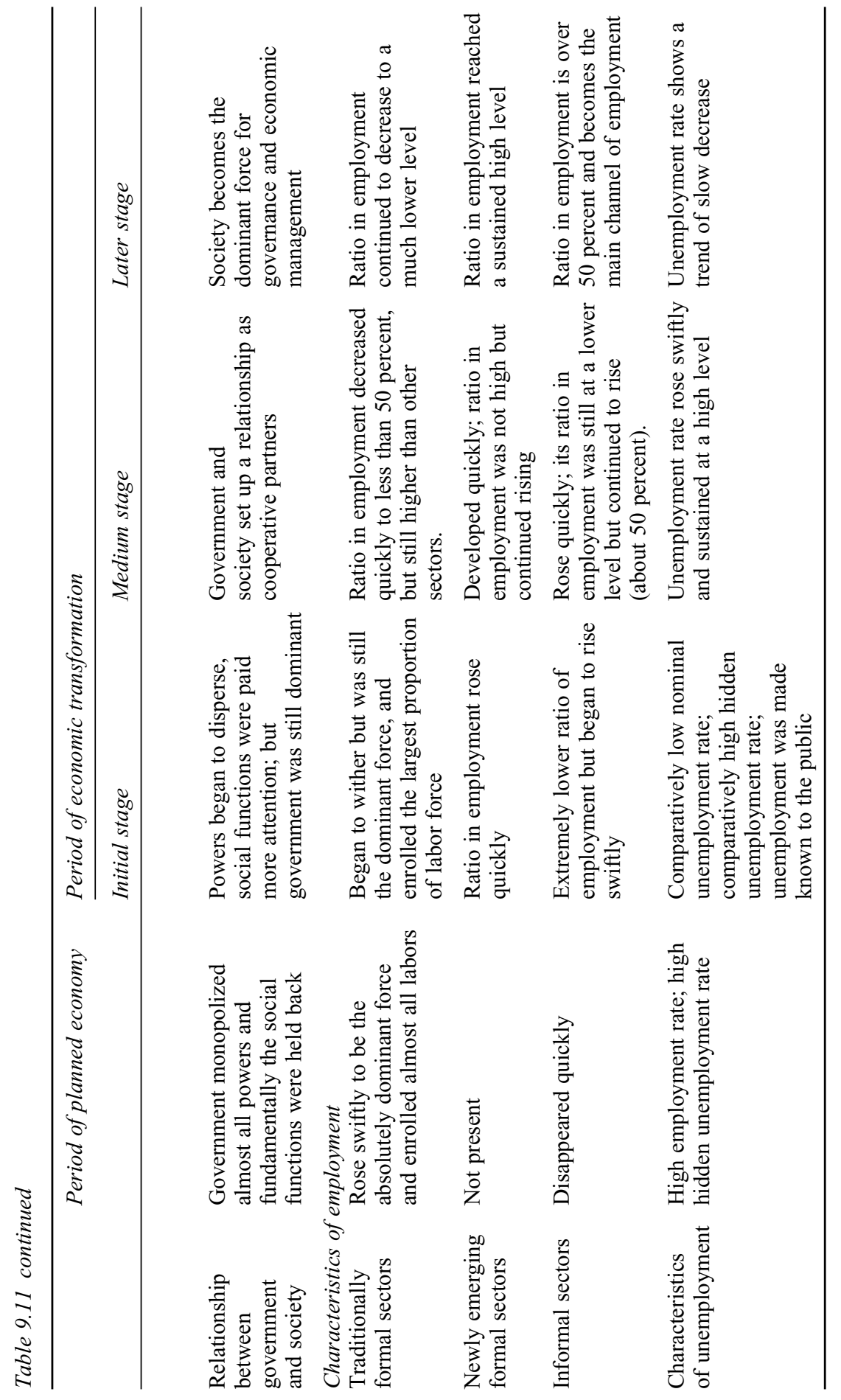




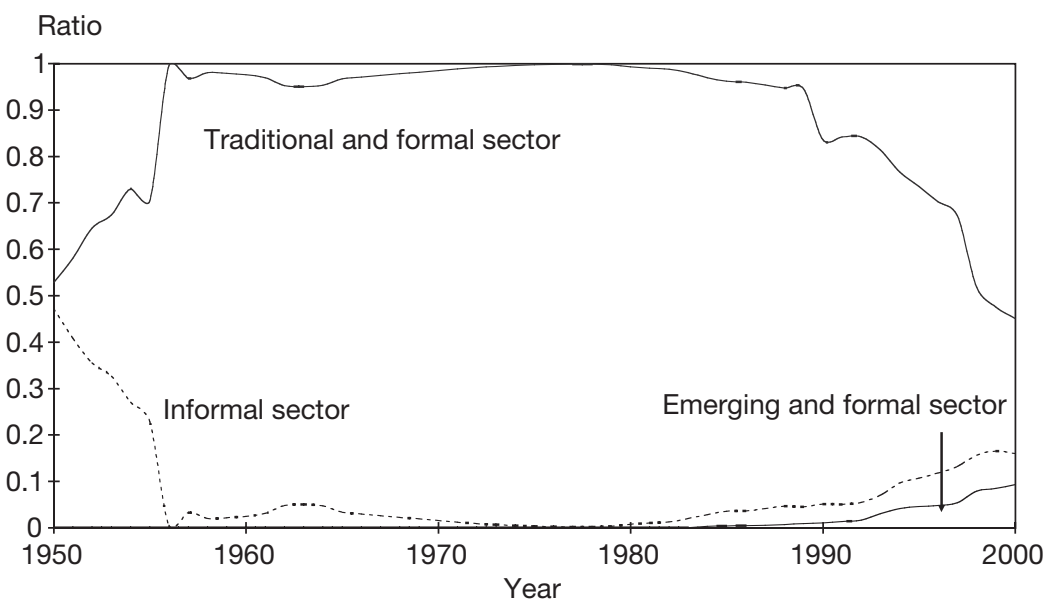

Figure 9.6 Proportion of employment by sector (1950-2000)

Fourthly, the ratio of informal sectors (privately owned enterprises and selfemployed businesses) in total employment increased substantially from 10.7 percent in 1995 to 16.0 percent in 2000 .

Fifthly, the ratio of urban formal sectors in China's employment is much higher than the average level of the developing countries. However, the ratio of urban informal sectors in China's employment is much lower than the average level of the developing countries, ${ }^{12}$ and lower than most of the developed countries. ${ }^{13}$

Sixthly, the employment increase in informal sectors has become the dominant channel for China's urban employment. During the Ninth Five-Year Plan Period (1995-2000), the number of urban employees increased by 21.81 million or by a proportion of 10.1 percent; at the same time, employees in informal sectors increased by 13.59 million or by a proportion of 66.5 percent, which was about 62.3 percent of the total increase in new employees. Meanwhile, employees in formal sectors (including traditional formal sectors and newly emerging formal sectors) decreased by 36.49 million. In conclusion, informal employment became the most important source for the increase of new urban jobs.

Seventhly, informal employment is the main channel of re-employment for the unemployed and laid-off workers. The proportion of self-employment in the re-employment of laid-off workers in 1999 was 48.7 percent, and at least 80 to 90 percent of the laid-off workers were re-employed in informal sectors.

According to the preceding analysis, urban employment in informal sectors has great potential. In the future, it will be one of the main channels for new increases of jobs. Finally, it is worth pointing out that institutional barriers in the labor market (such as the social insurance system, household registration system, and so on) severely hinder the free flow of labor between urban and rural areas or across sectors and regions, and constitute the greatest barrier to 
the development of the informal employment model, and the main cause for the unemployment rate to remain high for a comparatively long period.

\section{Conclusion and suggestions}

The population in China is about 21 percent of the total world population, the labor force is about 26 percent of the total world labor force, and China's agricultural labor force is more than one-third of the world agricultural labor force. This is one of the basic national conditions of China. To create more employment opportunities and transfer more of the agricultural labor force to nonagricultural activities while improving productivity gradually remain the biggest challenge for China's economic development in the long run, and one of the most difficult problems for human development across the world. The ratio of employment to population has increased sharply from 36.1 percent in 1952, to 41.7 percent in 1978 , to 56.6 percent in $1998 .{ }^{14}$ A substantial reason for this was the change in the age structure as a result of the national effort at birth control. The rise in the ratio gave a bigger once-and-for-all boost to production potential than other catch-up countries achieved.

Since China undertook reforms more than twenty years ago, its economy has been entering a takeoff stage. During the 1980s, the growth rate of China's economy reached 9 percent, and employment increased at an annual average rate of 3 percent (within which the non-agricultural employment increase rate was as high as 6.8 percent, and the urban increase rate reached 4.7 percent); the average unemployment rate was lower than 3 percent. Thus the aims of high-speed economic growth, high employment increase and low unemployment rate had been achieved.

Since the last half of the 1990s, China's economy entered an unprecedented period of restructuring accompanied by a high unemployment rate and low employment. In the past five years, the average annual increase rate of nationwide employment was only 0.9 percent, the lowest since the establishment of the People's Republic of China. The destruction of traditional jobs was the largest in scale in the world. Such traditional formal sectors as state-owned and collective-owned units, for example, cut 47 million jobs, yet the new formal sectors and new informal sectors, such as private-owned and individual enterprises, had only created 15 million new jobs, so it was typical of a "process of creative destruction." At present, the number of real urban unemployment is about 17 million, which sets the highest national record since 1949, with the real unemployment rate at about 8 percent. The ratio of long-term unemployment to overall unemployment is over 80 percent, and that of laid-off unemployment is up to 60 percent. The ratio of state-owned enterprises's lay-offs to total laid-off unemployment is up to two-thirds, due to the fact that 60 percent of the SOEs are making losses. The ratio of unemployment of the mining and quarrying, manufacturing and construction industries in overall laid-off workers is up to 80 percent. Thus, we can call it a "structural unemployment." 
Following China's accession to the WTO, the biggest challenge China faces is unemployment, and the problem could get worse. On one hand, new industries (such as IT, tourism, finance and insurance, culture, education and public health), newly emerging formal sectors (such as foreign invested sectors), and informal sectors (privately-owned and individual enterprises) will create new jobs. On the other hand, traditional formal sectors will cut more jobs. The race between the two driving forces will directly affect changes in employment and unemployment rates, which will have three stages. In the first stage, more existing jobs will be cut than new jobs created. Since most people work in traditional industries and the ratio of employment in new industries is small, there will be a rapid increase in the unemployment rate. In the second stage, new jobs will increase in greater numbers, and laid-off workers will find new jobs. Although the unemployment rate remains high, the surging trend will slow down or stop. In the third stage, more new jobs will be created than job-cuts, more and more new laborers will enter into new industries directly, a large proportion of the unemployed will enter into the new industries gradually, and the rate of unemployment will decrease. The process of economic growth itself is not only an increase in production, but also a process of restructuring. In other words, restructuring is a process of partial or even overall qualitative change caused by economic development.

To face the challenges of large-scale restructuring following accession to the WTO, the most important policy arrangement is to carry out an employment priority strategy, and to create a lot of different (formal and informal) jobs; thus economic growth will promote an increase in employment. To achieve these goals, we need to undertake employment-concentration or labor-concentration action projects, and link them with present public investment and public engineering plans. We need to promote a positive labor market to improve re-employment opportunities and the employment competitiveness of the unemployed. Also the following actions are recommended: to improve the free movement of the labor force, to provide employment service information and monitor the key indices of the labor market; to speed up the restructuring of formal sector employment; to decrease the ratio of traditional formal employment and enlarge the scale of newly emerging formal employment; to promote the development of informal employment; to encourage self-employment, independent employment, household employment and community employment; to encourage the development of small enterprises and help the transformation of traditional industries or enterprises.

My second policy suggestion is to set up a large-scale, low-level but highly agile unemployment insurance system; to provide effective, necessary and fundamental protection for the temporarily unemployed, to enlarge the scope of basic unemployment guarantees from state-owned enterprises and formal sectors to non-state-owned enterprises and informal sectors; to modify the criteria of unemployment insurance; and at the same time, to further broaden the medical insurance of on-post staff (dabing tongchou) and the coverage of insurance for occupational injury. 


\section{Genuine national savings and natural capital cost in China (1970-2001) ${ }^{1}$}

During the past twenty years, China has been one of the countries whose economic growth rate is the fastest in the world, and whose domestic savings rate (as a percentage of GDP) and domestic investment rate (as a percentage of GDP) are the highest. According to the statistics of the World Bank, ${ }^{2}$ the average GDP growth rates of the 1980s and the 1990s in China were respectively 10.1 percent and 10.7 percent, ranking second among the 206 countries and regions in the world (only second to Botswana, a naturally abundant African country) in the 1980s, and the first in the 1990s. In 1999, the domestic savings rate and investment rate in China were respectively 42 percent and 40 percent, the highest in the world, 20 percent higher than the average world level at that time. However, according to the World Bank Database, the cost of natural capital in China is also shockingly high. To a great extent, it counteracts the nominal domestic savings rate and investment rate, cutting down at least 20 percent of the genuine domestic savings rate in 1985 , down to 4.5 percent in 1998 , and reversed to 6.3 percent by $2001 .^{3}$

Presently, the national economic accounts system, which is based on nominal GDP, has severe flaws. It does not take out the cost of natural capital, and puts the values of overexploited resources and energy, especially non-reproducible resources, into the GDP as additional value. This will exaggerate economic income at the expense of rapid consumption of natural resources and severe deterioration of the environment, and will inevitably lead to great reductions in real national welfare. Therefore, it is necessary to amend the current national accounts system. ${ }^{4}$

Since 1995, experts from the World Bank began to redefine and measure the world's wealth. They proposed the green national accounts system to measure national wealth. ${ }^{5}$ The meaning of so-called wealth is comprehensive. It includes produced assets, natural capital and human resources, among which production capital is traditionally measured by the national economic accounts system as national wealth, whereas natural capital and human resources are significant parts of national wealth in the new synthesized national economic accounts system. Green GDP is a new type of national wealth, or a new type of income estimation. Human resources are the most important part of real national wealth, accounting for about 40 to 80 percent of gross national wealth. Generally 
speaking, the rate of advanced countries is higher than that of countries with abundant natural resources. Production capital is the second important factor, accounting for 15 to 30 percent of gross national wealth. Natural resources rank third, accounting for 2 to 40 percent, although this factor is listed in second place in some regions in the Middle East and West Africa.

The World Bank first proposed the concept and calculation method of genuine domestic savings, which is the real savings rate of a country, after the depletion of natural resources (especially non-reproducible resources) and the cost of environmental pollution are deducted. ${ }^{6}$ Natural resources depletion is measured by the economic rent of exploiting and procuring natural resources. Rent is the difference between the production price (calculated by the international price) and total production costs. These costs include the depreciation of fixed capital and return of capital. One thing must be pointed out: the rational exploitation of natural resources for necessary to promoting economic growth; however, if the resource rent is too low, it will induce over-exploitation. If the resource rents are not put into reinvestment (e.g. investment in human resources), but are put into consumption, this is "irrational." Pollution costs mostly refer to $\mathrm{CO}_{2}$ pollution. This is calculated by the global marginal cost caused by emission of one ton of $\mathrm{CO}_{2}$, for which Fankhauser suggested 20 US dollars. ${ }^{7}$ This calculation does not include air, water and other pollution. According to the calculation of the World Bank, 39 percent of the gross wealth in the Middle East comes from natural capital, most of which is oil and natural gas. After taking out natural resources depletion, the genuine savings rates in these countries are all negative (see Table 10.1). According to the research of Sachs and Warner at Harvard University, ${ }^{8}$ ever since the 1970s, the economic growth rate of countries with abundant natural resources has been much lower than that of countries with barren natural resources. The study of the World Bank also shows that countries relying heavily on natural resources suffer greater costs, and the genuine domestic savings are low or even negative.

Table 10.1 Genuine savings rate (1970-1993) (ratio as a percentage of GDP, \%)

\begin{tabular}{lcrr}
\hline Regions and income types & $1970-1979$ & $1980-1989$ & $1990-1993$ \\
\hline Regions south of the Sahara, Africa & 7.3 & $-3.2(1.7)$ & $-1.7(2.4)$ \\
Latin America and Caribbean & 10.4 & $1.9(1.7)$ & $5.1(3.4)$ \\
East Asia and the Pacific Ocean & 15.1 & $12.6(8.0)$ & $19.3(7.4)$ \\
The Middle East and North Africa & -8.9 & $-7.7(2.0)$ & $-7.0(3.0)$ \\
South Asia & 7.2 & $6.5(5.7)$ & $6.9(5.7)$ \\
High income OECD countries & 15.7 & $12.4(3.1)$ & $14.5(2.4)$ \\
Low income group & 9.8 & $3.3(4.4)$ & $8.2(2.4)$ \\
Medium high income group & 7.2 & $2.9(3.2)$ & $8.9(3.5)$ \\
High income group & 15.2 & $12.3(3.1)$ & $14.7(2.4)$ \\
\hline
\end{tabular}

Sources: K. Hamilton and M. Clemens, "Genuine Savings in Developing Countries," World Bank Economic Review, 1999, vol. 13; World Bank, World Development Report 2000/2001: Attacking Poverty, Oxford University Press, 2000.

Note: Data in the brackets are economic growth rate in the 1980s and 1990s. 


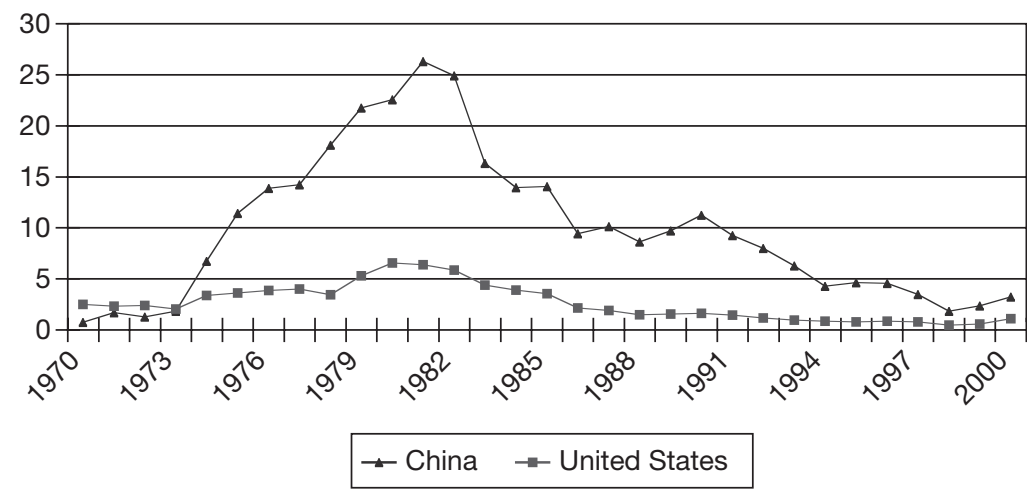

Figure 10.1 Energy depletion cost (1970-2000) (\% of GDP)

Source: World Bank, World Development Indicators CD-ROM 2002.

The World Bank estimated various natural resource costs in many countries since $1970 .{ }^{9}$ Here we list the data for China, USA and Japan. The conclusions are: First, energy depletion accounts for the greater part of natural capital cost. The natural capital cost as a percentage of GDP experienced a rising and falling curve (see Figure 10.1). In the 1970s, with large-scale oil and coal exploitation, the natural capital cost as a percentage of GDP rose sharply, and peaked in 1980 (close to about one-quarter of GDP). In the late 1980s, it fell to about 10 percent, and further declined to a little over 5 percent in the early 1990s. During recent years, the rate dropped rapidly to less than 1.5 percent in 1998, and reversed to 2.8 percent in 2001 . Such changes showed that the industrial restructuring, especially energy consumption restructuring, during the Ninth Five-Year Plan was one of the key reasons for the declining share of energy depletion as a share of GDP. Energy depletion accounts for a large share of natural asset costs, and had an influential effect on cutting down the natural capital cost rate as a percentage of GDP during this period. However, entering into Tenth FiveYear Plan, the economic development in China, driven by high capital input and high energy depletion rather than technological progress and improved efficiency, reverted back to the low-quality, high-growth path. According to the latest statistics of BP in 2004, China's coal production accounted for 33.5 percent of the world total (US coal production was 21.9 percent of the world total) in 2003, and China's coal consumption accounted for 31.0 percent of the world total $(22.3$ percent for the US). These two shares are much higher than the share of China's population and China's GDP in the world total. Thus we can draw the conclusion that China is the world's largest dirty energy producer and consumer. The dirty energy production and consumption has not only made the Chinese people the gravest victims, but also affected the global environment and the safety of mankind to a large extent. 
Second, the cost of $\mathrm{CO}_{2}$ pollution ranks second as a percentage of GDP. In the 1970s, the cost was over 4 percent, and around 4 percent in the 1980s. In the $1990 \mathrm{~s}$, the rate began to decline. The declining trend was especially obvious during the late 1990s and reached 2.33 percent in 1998, the lowest point since the 1970s. However, compared with other countries, this rate is still much higher than that of the USA and Japan (see Figure 10.2). There is one more thing to add: the calculation does not include the cost of water pollution, $\mathrm{SO}_{2}$ and other noxious emissions pollution. If these are taken into account, the total cost of pollution will probably be 3.5 percent. The World Bank calculated China's cost caused by air and water pollution using the human capital method, and the result accounted for 3.8 to 7.8 percent of GDP. ${ }^{10}$ The decrease of the cost of $\mathrm{CO}_{2}$ emission as a percentage of GDP during the late 1990s also helps to reduce the rate of natural resources as a percentage of GDP. We noted that $\mathrm{CO}_{2}$ emission as a percentage of GDP presents a rising and falling curve since the middle of the 1960s, and during the late 1990s it shows an obvious trend of falling (see Figure 10.3). This phenomenon indicates that economic growth rate is higher than the $\mathrm{CO}_{2}$ emission rate. The increase of their difference implies that the intensity of pollutant emissions is decreasing. However, due to the high growth of energy consumption during the Tenth Five-Year Plan, especially the rapid increase in coal consumption, the $\mathrm{CO}_{2}$ emission cost in 2003 might reverse back to the level of the mid-1990s.

Third, mineral consumption or depletion ranks third in natural capital cost. During the past twenty years, there have been two successive exploitation depletions (see Figure 10.4). The first exploitation depletion took place between the late 1970 s and the early $1980 \mathrm{~s}$, and the cost accounted for 1.2 percent of GDP. The second one was between the late 1980s and the early 1990s, and the cost

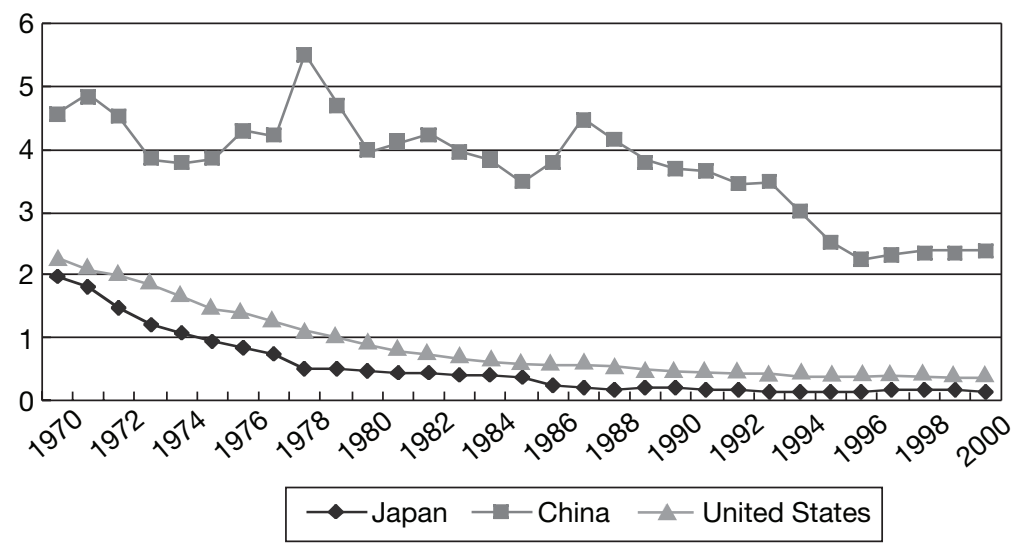

Figure $10.2 \mathrm{CO}_{2}$ emission cost as share of GDP (1970-2000) (\%)

Source: World Bank, World Development Indicators CD-ROM 2002. 


\section{Economic and social transformation in China}

was 0.8 to 1.2 percent of GDP. Since the $1990 \mathrm{~s}$, this cost as a percentage of GDP fell sharply down, to less than 0.2 percent in 2001. The mineral output of the US is very large, but its mineral depletion cost as a percentage of GDP is much less than China's.

Fourth, the cost of forest depletion as a percentage of GDP is comparatively the smallest. However, this shows a rising trend ever since the reform, growing from less than 0.2 percent of GDP up to 0.8 percent in the middle of the 1990s. During the Ninth Five-Year Plan period, this rate dropped substantial, declining to 0.43 percent in 1998 , and 0.07 percent in 2000 , but increasing to 1.0 percent in 2001 (see Figure 10.5). There is one thing to be pointed out. Since the reform, timber output has grown, peaking at 67,673 in 1995. After that, the government carried out a project to protect natural forests, forbade

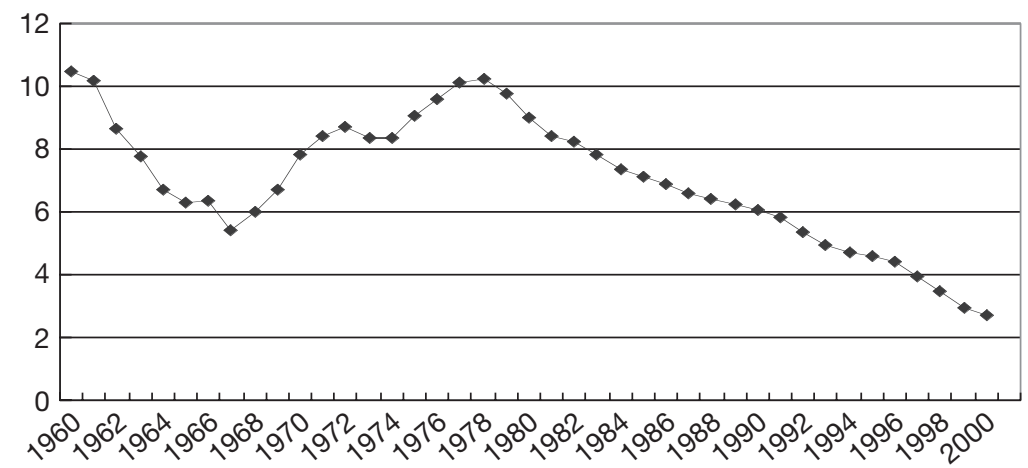

Figure 10.3 China's unit GDP $\mathrm{CO}_{2}$ emission (1960-2000) (kg/1995 US dollar) Source: World Bank, World Development Indicators CD-ROM 2002.

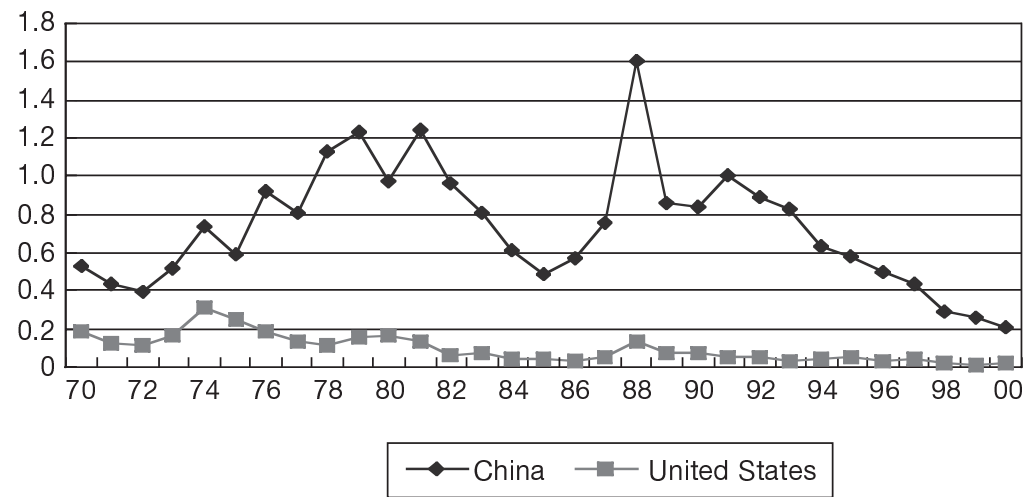

Figure 10.4 Mineral resources depletion as share of GDP (1970-2000) (\%) Source: World Bank, World Development Indicators CD-ROM 2002. 


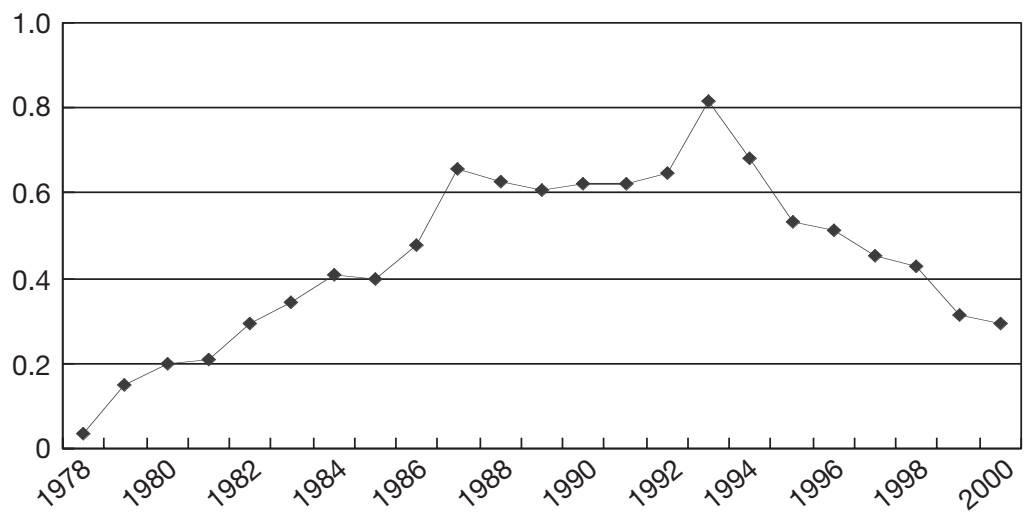

Figure 10.5 China's forest depletion as share of GDP (1978-2000) (\%)

Source: World Bank, World Development Indicators CD-ROM 2002.

deforestation, cut down the timber output target, and increased timber imports. By 2002, timber output decreased to 44.36 million steres, which is one-third (34.4 percent) lower than in 1995 (see Figure 10.6). If the current forest protection policy can be carried on, the forest depletion cost as a percentage of GDP in future years will be less than 0.2 percent. During the past fifty years, the cardinal point of China's forestry policy was to "cut big woods." The Ministry of Forestry was also known as the "Ministry of Felling;" the state-owned forestry enterprises were "felling enterprises" that destroyed the forest ecology. China experienced a process of large-scale exploitation and rapid forest resources depletion. Not until the late 1990s did this situation begin to reverse towards limited felling and vigorous protection. History shows that we did not have a deep understanding of China's basic situation, and took a false step of "first destroy, then protect." According to the data provided by the World Bank, ${ }^{11}$ although the natural capital per capita of China is only a bit higher than that of Japan, the forest resource capital per capita of Japan is 2.4 times greater than that of China. The forest coverage rate in Japan is as high as 65 percent. However, Japan sill keeps importing timber at a large scale, accounting for 22.4 percent of the world's gross amount in 1998, whereas the import amount of China accounted for only 4.7 percent. Canada, Russia and the USA are the three largest timber export countries, accounting for 45.0 percent of the international timber export market. ${ }^{12}$ This situation indicates that China needs to further cut down the import tariffs on timber and its processed products (e.g. paper or paper pulp), or even to practice zero tariffs, so as to expand its power of utilizing the international forest resources, and to protect the domestic forest resources for the next fifty years.

Fifth, China's cost of natural capital as a percentage of GDP is shockingly high. It follows a rising and then falling process (see Figure 10.7). According to this measure, we can give an objective evaluation of the economic, energy 


\section{Economic and social transformation in China}

and environment protection policies and their effects at different times. During the early 1970s, the cost accounted for 6 to 7 percent of GDP. Between the late 1970s and 1980s, the economic cost reached its peak, as high as 30 percent of GDP. After that, it began to drop, reaching about 15 percent in the late 1980 s. Just as the author pointed out in the national situation report "Subsistence and Development" (1989), economic development in the early days of the reform was at the expense of natural resources and a case of ecological environment "overdraft." The expense is much more costly by far than the estimate made at that time. In the $1990 \mathrm{~s}$, the cost began to fall. Up to 1995, it decreased by half to 7.80 percent. During the late 1990s, this falling trend was quite distinct, reaching a low of 4.53 percent in 1998 (see Table 10.2). The changing trend of natural capital cost as a percentage of GDP reflects the fact that China

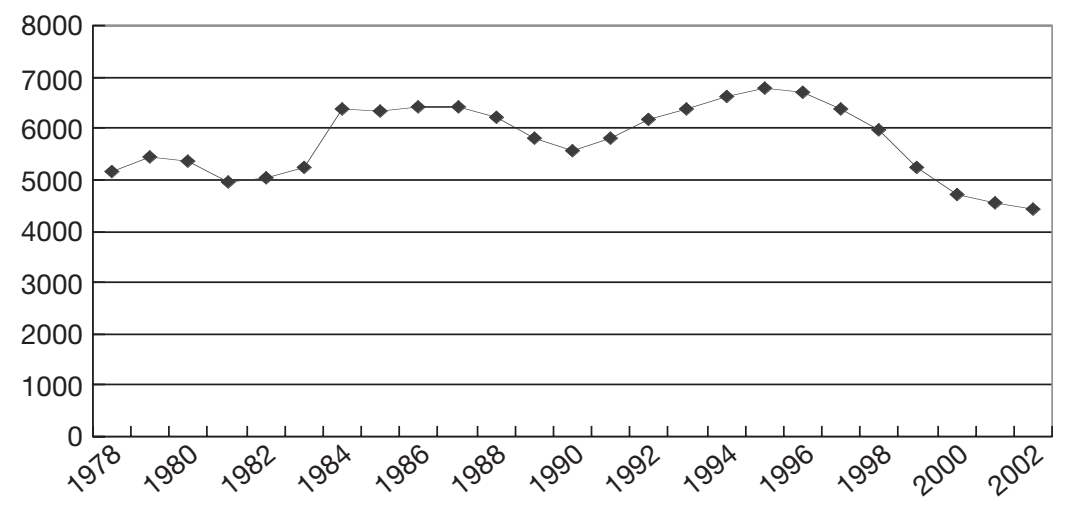

Figure 10.6 China's timber production (1978-2002) (10 thousand steres)

Source: World Bank, World Development Indicators CD-ROM 2002.

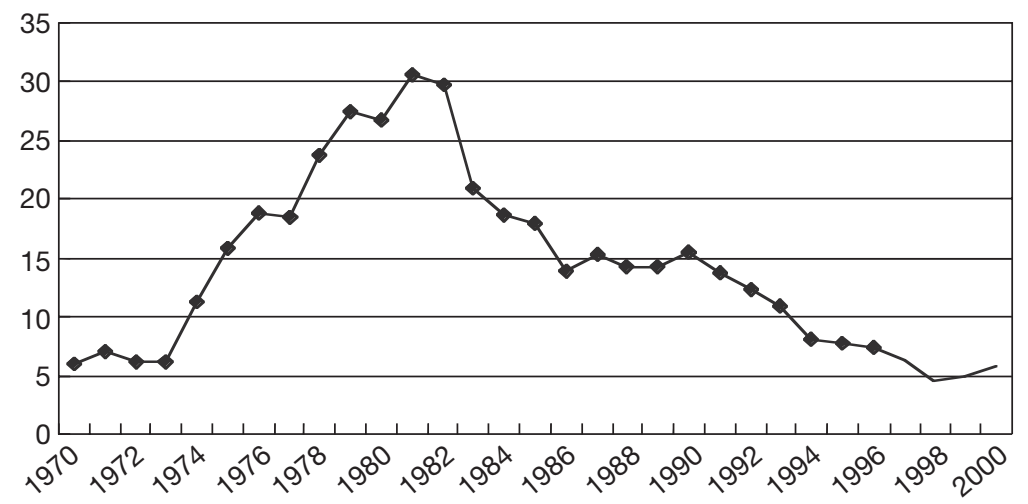

Figure 10.7 China's natural capital cost as share of GDP (1970-2000) (\%)

Source: World Bank, World Development Indicators CD-ROM 2002. 
experienced a big detour during the past twenty years, which was "first destroy, then protect; first pollute, then purify; first deplete, then retrench; first fell, then plant." For this, both the country and the people have paid a heavy price. The genuine domestic savings rate is greatly discounted by the cost in natural resources. This is reflected in the trend of genuine domestic savings rate, which gradually rises after a sharp fall. Since, after taking out the natural capital cost, the net domestic savings rate appears to rise after the 1990s, the two curves tend to converge (see Figure 10.8).

To sum up, in the traditional national economic accounts system, neither the high economic growth rate nor the high domestic savings rate could really identify the genuine national wealth and the cost of natural resources. Only the new green GDP national economic accounts system can faithfully reflect the above circumstances. Though there are still some defects in the assessment of the World Bank, it provides us a clear description of the historical environment and development track China has experienced during the past twenty years. It describes the transformation of China's economic growth model, its changing trend of natural capital cost as a percentage of GDP, and the international comparison. Thus, it offers a beneficial reference for expanding the genuine national wealth, especially improving the genuine domestic savings rate. We should significantly reduce the depletion of non-reproducible energy, mineral resources and forest reserves. And we should also transfer from the highly "autarkic" traditional resources security strategy of using domestic scarce resources to the new global resources security strategy, that is, making full use of both kinds of resources, especially the global strategic resources, such as oil, natural gas, timbers and wood products. This is because China's three main types of resource reserves respectively account for 2.36 percent, 0.94 percent and 3 percent of the world's

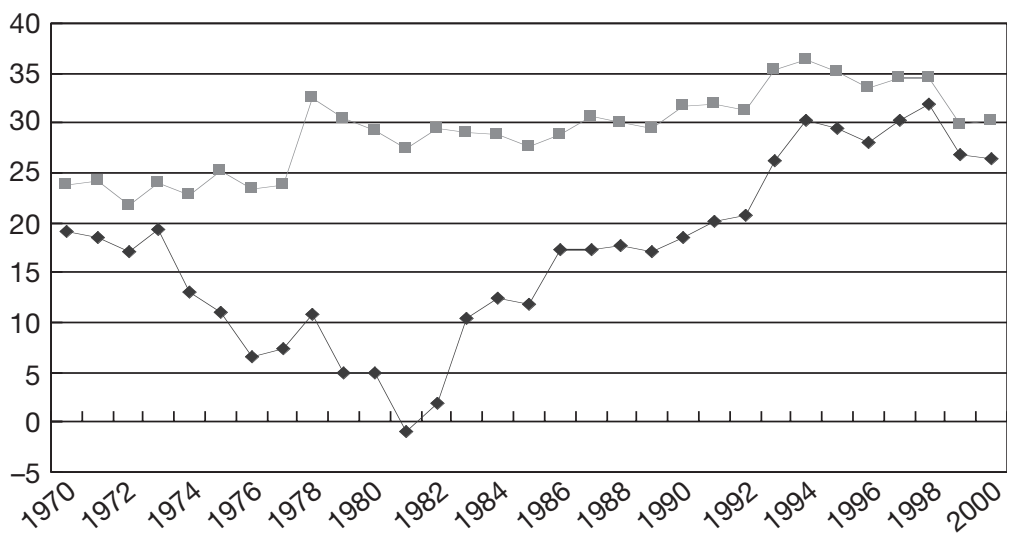

Figure 10.8 Genuine domestic savings and net domestic savings rate (1970-2000) (as percentage share of GDP)

Source: World Bank, World Development Indicators CD-ROM 2002. 
Table 10.2 Natural capital and genuine domestic savings rate in China (1980-2001) (ratio as a percentage of GDP, \%)

\begin{tabular}{lrrrrrl}
\hline & 1980 & 1985 & 1990 & 1995 & 1998 & 2001 \\
\hline Gross domestic investment & 35.19 & 37.77 & 34.74 & 40.83 & 38.28 & 34.16 \\
Domestic savings & 35.19 & 33.48 & 37.95 & 43.13 & 42.63 & 40.9 \\
Net domestic savings & 29.32 & 27.69 & 31.73 & 35.18 & 34.5 & 30.9 \\
Energy depletion & 22.53 & 13.66 & 10.28 & 4.19 & 1.48 & 2.8 \\
Mineral depletion & 0.96 & 0.48 & 0.84 & 0.58 & 0.29 & 0.2 \\
Net forest depletion & 0.21 & 0.70 & 0.62 & 0.53 & 0.43 & 0.1 \\
$\mathrm{CO}_{2}$ damage & 2.34 & 3.48 & 3.69 & 2.50 & 2.33 & 2.2 \\
Natural capital cost & 26.03 & 19.83 & 15.43 & 7.80 & 4.53 & 6.3 \\
Education expenditure & 2.27 & 2.21 & 2.18 & 1.98 & 2.00 & 2.00 \\
Genuine domestic savings & 4.86 & 11.87 & 18.47 & 29.38 & 31.98 & 26.6 \\
\hline
\end{tabular}

Source: World Bank, World Development Indicators CD-ROM 2002; World Development Indicators CD-ROM 2003.

gross reserves. ${ }^{13}$ By boosting both import and export growth, especially the export of labor-intensive and technologically intensive products, we can increase the efficient use of international resources for import and procurement. We should open up energy and timber import markets, practice zero tariffs, eradicate tariff barriers, eliminate the distortions of the domestic price system and market, and establish an energy reserve system for the country and its enterprises. We should significantly cut down coal consumption, eliminate the subsidy for coal production and transportation, firmly close small-scaled thermal power stations, encourage using clean energy and reproducible energy, and stop environmental pollution. We should also carry out environmentally friendly industrial strategies and economic development strategies, increase environmental capital, and improve the environmental quality of people's lives. This means increasing all the people's natural capital, and significantly improving the national investment in human resources, which include education, sanitation and health, family planning and procreation health, and investment in R\&D and so on. This also implies improving everyone's developing ability, and increasing everyone's real wealth. 


\title{
11 Corruption: an enormous black hole
}

\author{
Public exposure of the economic \\ costs of corruption ${ }^{1}$
}

Corruption has become a major enemy of economic development and social stability in China, and has caused prodigious economic costs for the country and its people. The estimate of economic costs resulting from corruption is very difficult. Corruption is often called a "black hole," which is an invisible abyss. It is necessary to know, during the transformation period of the Chinese economy, which areas and departments are the most corrupt, why they are easily corrupted, how to determine the key areas for preventing corruption, and in what areas the anti-corruption measures can effectively reduce economic costs. To answer these questions, we have to make a preliminary estimate of the economic costs of corruption, however crude and inaccurate it might be. According to my calculation of four major types of corruption during the economic transformation period in China (i.e. corruption in rent-seeking, the underground economy, evasion of taxes, and government investments and public expenditure) in September 2000, during the late 1990s, just these four major types of corruption each year have on average resulted in economic costs of about 13.3 to 16.9 percent of GDP. ${ }^{2}$

People were shocked by the figures. Some thought I had overestimated the coverage of corruption and exaggerated its economic cost. ${ }^{3}$ This is quite normal for academic debate. To thoroughly probe the types and economic costs of corruption, we still need to collect more detailed materials, make full use of the data of more authoritative institutions, and continue to unveil the disguises of corruption, to deeply explore the black hole of corruption, and to publicize the results so as to make an important contribution to anti-corruption.

Recently, some departments of the Chinese government successively publicized events to penalize corruption and economic costs, which I summed up as ten types of systematic economic costs caused by corruption. They add up to economic costs of enormous sums, which are caused by government departments or public institutions who abuse their power for their own interests. This kind of economic cost amounts to, on average, 14.5 to 14.9 percent of GDP each year between 1999 to 2001 .

1. Economic cost caused by official corruption, bribery and defalcation. According to the material submitted by Xiao Yang, dean of the Supreme People's 
Court of China, to the third session of the Ninth National People's Congress, the directly recovered economic cost amounted to 2.24 billion RMB, through punishing smuggling, obtaining foreign exchanges by fraud, financial swindling, and cheating on invoices for value-added tax. The directly recovered economic cost by punishing crimes like corruption, bribery and defalcation reached 1.5 billion RMB. ${ }^{4}$ Both of these added up to 3.74 billion RMB, accounting for 0.04 percent of GDP in 2000. We found that, compared with the gross economic cost resulting from all types of corruption, those caused by official corruption, briberies and defalcations are only "a mite on an elephant."

2. Tax evasion by smuggling at customs. In 1998, customs uncovered 7,328 smuggling crimes, whose values amounted to 13.7 billion RMB. ${ }^{5}$ In 1999 , uncovered smuggling crimes were worth about 80 billion RMB, and customs tax increased by 71 billion RMB in 1999.6 The two respectively accounted for 0.17 percent and 0.97 percent of GDP in 1998 and 1999. The world's biggest smuggling case, that of the Yuan Hua group, involved 53 billion RMB and dodged taxes of 30 billion $\mathrm{RMB},{ }^{7}$ equivalent to 53 percent of customs tax and 0.34 percent of GDP in 1999. Taking 1995 as the base, in 1999, the import volume increased by 4.3 percent and the customs tax volume increased by 92.7 percent. Excluding the factor of the import volume increase, the net income of customs tax would increase by 55 percent, which would be about 16 billion RMB, accounting for 0.20 percent of GDP in 1999. Excluding the factor of import volume increase, the net income of customs tax would increase by 52.4 percent, about 15.3 billion RMB, accounting for 0.17 percent of GDP in 2000.

3. Economic cost caused by corruption of industry monopolies. According to data provided by the State Development Planning Commission of China, the telecoms industry has illegally charged users 2.17 billion RMB since 1998, and the power industry 2.74 billion $\mathrm{RMB}^{8}{ }^{8}$ for a total up to 4.91 billion RMB, accounting for 0.06 percent of GDP in 1999. According to data of the National Power Corporation, in 2001, 365 counties in China charged the same electricity price for cities and counties. It relieved peasants of 35 billion RMB. ${ }^{9}$ However, these 365 counties account for only 13 percent of 2,861 counties in China. According to my estimate, this unfair charge is equivalent to 7.5 percent of the consumption level of countryside dwellers and equivalent to 0.37 percent of GDP in that year. According to data provided by the Style Rectification Office of the State Council and Ministry of Health, in 2001, measures to rectify the unhealthy tendency in the purchase and sale of medicaments relieved patients of 10.1 billion RMB, which is estimated at about 2.8 percent of the average consuming level of citizens in the country, accounting for 0.11 percent of GDP in that year. The State Development Planning Commission and commodity price offices in provinces reduced high prices for medicaments by a total of 8.1 billion RMB. Nineteen-thousand cases of illegal purchase and sales of medicaments were penalized, involving 1.08 billion RMB. ${ }^{10}$ According to data provided by the State Development Planning Commission, 236,000 cases of price breaches 
were penalized in the country from January to November in 2001, involving prices and charges in the countryside, education, prices of medicaments and medical treatments, charges by administrative offices and facilities, and price cheating and price discrimination. The economic punishment totaled 3.15 billion RMB. ${ }^{11}$ These illegal charges took advantage of industry monopolies and were forcefully levied on all users and consumers.

4. Economic cost of tax evasion. The national tax department penalized 9.37 billion RMB for breaching tax law, accounting for 0.105 percent of GDP in that year. Eighteen central departments did not submit correct income, which was 1.7 billion RMB, and twenty departments detained financial capital of 5.6 billion RMB. ${ }^{12}$ This does not include defaulted tax of state-owned enterprises or unsubmitted charges and fees in or outside of the budget.

5. Economic costs in public facilities and public expenditure. According to an audit of 120,000 state-owned enterprises and government offices by the National Audit Office, in 1998, unreported, embezzled or dissipated capital was about 100 billion RMB, accounting for 1.27 percent of GDP in that year. The key departments were finance, food supplies and monopoly industries. ${ }^{13}$ In 2000 , over 76 billion RMB of illegal capital was uncovered through audit, ${ }^{14}$ accounting for 0.85 percent of GDP in that year. From January to November in 2001, over 160 billion RMB of illegal capital was uncovered through audit in the country, ${ }^{15}$ accounting for 1.67 percent of GDP in that year. And one-third of these were big cases, involving large quantities of money. Through audit, twentytwo cases were disclosed and handed over to judicial organs, involving 59.5 billion RMB and sixty-one persons. On average, each case involved 2.7 billion RMB, 975 million RMB for each person in the case. Through a financial audit on eight state-owned key enterprises, 34.8 billion RMB in illegal money was uncovered, averaging 3.45 billion RMB for each enterprise. The financial audit of China Bank disclosed 2.7 billion RMB, excluding the other three state-owned key banks. Altogether 4.3 billion RMB of national debt was found to be embezzled or defaulted. In the education system, primary and middle schools were found to arbitrarily charge, exact and collect money for 3.9 billion RMB. Through audits of twenty-one national quarantine offices, 3.4 billion RMB of illegal capital was uncovered, averaging 162 million RMB for each office. Among this, 0.9 billion was for staff overpayment, averaging 42.86 million RMB for each office. A total of 10.5 billion RMB of embezzled financial capital has been returned; 10.6 billion RMB of tax and penalties has been turned in; and 2.2 billion RMB of defaulted national debt has been correctly returned to its proper position. ${ }^{16}$ In 1999, 76.8 billion RMB of loans for food and oil purchase was found to be embezzled, and 13.8 billion RMB was found to be falsely reported in the accounts by listing less income and more expenses than were the case. ${ }^{17}$ Both of these two totaled 90.6 billion RMB, accounting for 1.1 percent of GDP in that year. Thirty-six departments embezzled 2.1 billion RMB of financial capital in building and administrative expenditure. ${ }^{18}$ From 
1997 to early 1999 , the country had invested 48.8 billion RMB in poor counties to support the poor: 4.343 billion RMB was embezzled, falsely listed as expenditure, or moved into a unit-owned exchequer, accounting for 9 percent of the poor-supporting capital. In 2001, national disciplinary inspection departments uncovered 6.527 billion RMB of illegal money, saving economic costs of 2.286 billion RMB; 2.139 billion RMB of illegal money was returned, avoiding economic costs of 2.834 billion RMB. A total of 8,139 cases were put on file for investigation and prosecution. Nine thousand and seventy-two persons were penalized by party discipline, among whom 963 were handed over to judicial departments, accounting for 10.6 percent of the total penalized cases. ${ }^{19}$

6. Economic cost caused by corruption in public investment. According to an audit of the National Audit Office, in 1999, embezzled national debt amounted to 2.86 billion RMB. Fifty-eight key water conservancy projects embezzled 1.78 billion RMB of special capital. Falsely reported investments and wasted money reached 3.3 billion RMB. ${ }^{20}$ All of these totaled 6.16 billion RMB, accounting for 0.08 percent of GDP in that year.

7. Economic cost caused by capital flight. Capital flight means to transfer abroad income earned through illegal measures, such as smuggling, trafficking in drugs, money laundering, dodging taxes, swindling foreign exchanges, and trading inside or outside of China. It is estimated that a total of 98.8 billion US dollars was transferred from the country from 1997 to 1999. According to the State Administration of Foreign Exchange, capital flight from 1997 to 1999 amounted to 53 billion US dollars, averaging 17.7 US dollars each year, accounting for 2 percent of GDP in each year. In 1998, more than 10 billion US dollars of foreign exchanges were swindled, accounting for 1 percent of GDP in that year. $^{21}$

8. Economic cost caused by privatization of state-owned enterprises. Up to the end of 2000, 51 percent of the converted enterprises (32,140 in total) dodged 185.1 billion RMB of capital and interest from bank loans, accounting for 32 percent of total capital and interest of bank loans for converted enterprises (579.2 billion RMB in total), ${ }^{22} 2.07$ percent of GDP in that year.

9. Economic cost resulting from arbitrary charges by public institutions. Arbitrary charges are another form of corruption. It is administrative corruption, and is typical as a department abuses its public power over a small group of people. Since 1997, more than 40,000 items of arbitrary charges on enterprises (e.g. collecting money and raising funds) have been cancelled, involving 170 billion RMB, averaging 34 billion RMB each year, accounting for 0.42 percent of GDP. Since 2000, 29,227 items of arbitrary charges on township businesses have been brought into control, involving 23.67 billion RMB, averaging 810,000 RMB per item. ${ }^{23}$ By the end of June 2001, 26,798 items of 
arbitrary charges on township businesses have been cancelled, involving 22.6 billion $\mathrm{RMB},{ }^{24}$ averaging $840,000 \mathrm{RMB}$ per item. In 2001, 14.5 billion RMB in total of arbitrary charges were cancelled, greatly alleviating the burdens of peasants. ${ }^{25}$ This is estimated to be equivalent to 7.25 percent of the consuming level of countryside dwellers, averaging 18 Yuan RMB per person. According to statistics of the State Economic and Trade Commission, up to the end of October 2001, 27,055 instances of arbitrary charges on enterprises had been cancelled, involving 37.55 billion RMB ${ }^{26} 0.37$ percent of GDP in 2001.

10. Economic cost caused by financial industry. In the late $1980 \mathrm{~s}$, there were only several dozen registered cases of financial swindling. However, by the late $1990 \mathrm{~s}$, the number had increased to over 10,000 . In the $1980 \mathrm{~s}$, there were few cases involving over a million RMB, but at present it is normal to see cases over tens of millions or even billions of RMB. During only January to October in 2000, cases of financial swindling amounted to 8,000, involving 10 billion RMB. ${ }^{27}$ Cases involving economic law reached 59,000, involving 70 billion RMB, 0.9 percent of GDP in that year. Rescued money amounted to 12 billion $\mathrm{RMB}$, accounting for only 17 percent of the total amount in these cases. This indicates that more than 80 percent of the economic cost of economic crime (mostly involving corruption) cannot be recovered. By the end of 2000, the total volume of financial loans reached 68,000 RMB, among which 7 percent (467 billion RMB) were bad loans unable to be recovered, accounting for 5.35 percent of GDP in that year. The economic cost of the above two types of financial corruption accounts for 6.25 percent of GDP, ranking first in all types of corruptions.

If the repeatedly calculated amount is excluded, according to the preceding official statistics, during 1999-2001 the total economic cost of ten types of corruption amounted to 14.5 to 14.9 percent of GDP (see Table 11.1). These are only the corruption cases publicly exposed, a partial illustration of an increasingly rampant corrupt situation. In reality, there are even more types of corruption than these, and the real loss is far greater. We are far from calculating and estimating the real economic cost of corruption. It is still an unknown economic "black hole." It is hard to reflect the real economic cost of corruption in the current national economic account, the calculation of which is "man-made," and simply an "addition." Therefore, it is just nominal GDP in a statistical sense, far from the real "national welfare" in the real sense. For instance, when the loss of "natural capital" is excluded, the genuine national savings rate will be far less than the nominal one. We call the former green GDP, and the latter nominal GDP. Based on the same method, when "the economic cost of corruption" is excluded, the genuine national savings rate, which represents national welfare or net national welfare, will be far less than the nominal national saving rate. We can similarly call the former "clean" GDP, and the latter nominal GDP. It is known that the maximization of net national welfare does not equal that of nominal GDP. As for people and their country, only the maximization of net national welfare is really meaningful. 
Table 11.1 Economic costs of corruption (1999-2000)

\begin{tabular}{|c|c|c|c|}
\hline Corruption type & Year & $\begin{array}{l}\text { Economic } \\
\text { cost } \\
\text { (billion } \\
\text { RMB) }\end{array}$ & $\begin{array}{l}\text { Proportion } \\
\text { in GDP } \\
(\%)\end{array}$ \\
\hline
\end{tabular}

1. Official corruption, bribery and defalcation $\quad 2000 \quad 3.74 \quad 0.04$

2. Smuggling and corruption at customs

Values of penalized smuggling cases

Increase of net tariff

$\begin{array}{lll}1998 & 13.7 & 0.17 \\ 1999 & 80 & 0.97 \\ 1999 & 16 & 0.20 \\ 2000 & 15.3 & 0.17 \\ & 53 & 0.60 \\ 1998-1999 & 2.74 & \\ 2001 & 35 & 0.37 \\ & & \\ 1998-1999 & 21.7 & \\ 2001 & 10.1 & 0.11 \\ & & \\ 2001 & 3.15 & 0.03 \\ 2000 & 16.7 & 0.17 \\ 2000 & 9.37 & \\ 2000 & 1.7 & \\ 2000 & 5.6 & \\ & 210-220 & 2.35-2.46 \\ 1998 & 100 & 1.27 \\ 2000 & 76 & 0.85 \\ 2001 & 160 & 1.67 \\ 1999 & 90.6 & 1.1 \\ & & \\ 1999 & 9 & 0.11 \\ 1999 & 2.86 & \\ 1999 & 6.16 & \\ 1997-1999 & 53 \text { (dollars) } & 2\end{array}$

7. Loss caused by capital flight

$1997-1999-53$ (dollars) 2

8. Corruption loss of privatization of stateowned enterprises

$\begin{array}{llll}\text { Dodging capital and interest of bank loans } & 2000 & 185.1 & 2.07\end{array}$

9. Corruption loss in arbitrary charges

$\begin{array}{llll}\text { Arbitrary charges } & 1997-2001 & 170 & 0.42 \\ \text { Canceling illegitimate charges on township } & 2000 & 23.7 & 0.27 \\ \quad \text { enterprises } & 2001 & 22.6 & 0.24 \\ \text { Canceling illegitimate charges on enterprises } & 2001 & 37.55 & 0.37 \\ \text { Canceling illegitimate charges on countryside } & 2001 & 14.5 & 0.15 \\ \text { Corruption in financial industry } & 2000 & 547 & 6.25 \\ \text { Financial swindling cases } & 2000 & 10 & \\ \text { Economic low cases } & 2000 & 70 & \\ \text { Bad loans unable to be recovered } & 2000 & 467 & 5.35 \\ \text { Total } & 1999-2001 & 1290-1300 & 14.5-14.9\end{array}$

Notes: The proportion of total number in GDP refers to average estimates during 1999-2000. The total number of economic cost deducts some repetitions. 
The preceding calculation indicates that the economic cost of personal corruption is only "a mite on an elephant." The major part takes place in the corruption of groups, industries and enterprises. It is typical systematic corruption. The most distinct features include large quantities of money and abuse of public power, and the economic cost often ranks highest in the world. Corruption is not only a problem of economic cost. I call it "the largest social pollution" because corruption cannot create any new money and abuses public power by transfering social capital through unjust, unfair, concealed and illegal measures. It leads to greater inequality of social distribution. Like environmental pollution, it damages both people and the society.

It must be pointed out that, based on the calculation of purchasing power parity (PPP), the GDP of China accounts for over 10 percent of the world total, ranking second only after the United States. Up to the end of 2001, the GDP of China will be approximately eight times of that of 1978 (7.9 times), and to have created capital at that speed is one of the great wonders in human history. However, this was achieved at great economic cost and illegal capital transfers, caused by prevalent and systematic corruption (corruption cannot create money, but only transfer money). Whether income and capital of the 1.3 billion people or state revenue and capital, the real increase is much less than eight times. It is not exaggerated to say that China might be the country with the greatest economic cost of corruption in the world. Corruption has become the largest "black hole," devouring the fortunes of the people and the country.

The "black hole" of corruption is a kind of "product" of "leaks" in the country's system, or a function of its "leaks." The more the leaks, the more chances for corruption there will be, and the larger the black hole will be. Meanwhile, it is clear that when the party and the government take measures to prevent corruption, the economic cost of corruption will be reduced. Take the cancellation of arbitrary charges as an example. During the past five years (1997-2001), more than 170 billion RMB of economic cost was recovered. It is quite reasonable to believe that, as long as we have the perseverance to innovate and construct systems, we will be able to eliminate any leaks in the system. Thereby, the economic cost of corruption, the black hole, will be much reduced. 


\section{Second transition of the Communist Party of China

\author{
From economic development to \\ institution building ${ }^{1}$
}

\section{First transition: opening up an "era of economic construction"}

In 1978, the third plenum of the CPC's Eleventh Central Committee took the strategic policy decision to shift the central task of the Party from "taking class struggle as the key link" to socialist modernization and economic construction. The plenum held that the timely and summary shift of the emphasis of work to socialist modernization and economic construction to keep up with the development of both the internal and external situations reflected the requirements of history and aspirations of the people and represented the fundamental interests of the people. The plenum discarded the "leftist" erroneous principle of "taking class struggle as the key link," which was not suited to a socialist society, and settled the strategic shift problem that had not been resolved after the establishment of the basic system of socialism. ${ }^{2}$

This was the first transition in the central task of the CPC. It was regarded as a great historic shift in China. It opened up a new period of reform, development and opening up.

Ideologically, the CPC broke away from the long-time serious bondage to dogmatism and the personality cult and re-established the Marxist ideological line of seeking truth from facts and maintained and developed Mao Zedong thought. This was a period noted for the emancipation of the mind and change in concepts.

Politically, China ended decade-long disturbances caused by the "cultural revolution" and for the first time in history realized great order across the land, marked by social stability and easiness in the mind of the people, gradually established and improved socialist democracy and the legal system, and improved the democratic process of the Party and state and also the mechanism for formulating public policies and decisions, thus creating a lively political situation. This was the best period of political enlightenment since the founding of New China.

Economically, China experienced an unprecedented sustainable high growth to become one of the countries with the fastest economic growth. This was a period of economic prosperity in which development went the fastest and people's living standards rose the most significantly. 
Internationally, for the first time, China introduced economic and social opening-up policies and participated in economic globalization and sought greater benefits from it. This was the most open period in China's history.

The practice of reform and opening up over the past two decades and more shows that the strategic policy decision taken in 1978 of shifting the central work of the CPC to economic development was of great significance. It conformed to the national conditions and went along with the tide of development throughout the world. This was the first typical compulsory change in institutions in China and also the reform of institutions from the top down and from the bottom up. This was also an institutional reform with the biggest participation of people in the history of human development.

The biggest merit of the transition is that it created in contemporary China "good governance found during the period of Emperor Li Shimin of the Tang Dynasty." The "good governance" by Emperor Li Shimin lasted for twentythree years. It was one of the peak periods in the history of China's development. It also represented the highest level of development in the world at the time. Now, twenty-four years have passed since China introduced the reform and opening up policies, during which China has experienced the succession of two generations of leadership, matching the time span of the "good governance period." What is different from the earlier period is that the current great order across the land was achieved under the condition of opening up. This not only represented the best historical period but also made the most important contributions to the development of humanity.

\section{Second transition necessary: to create an era of "institution building"}

In the twenty-first century, the long-term development goals are not only to realize economic modernization, following the "three-stop strategy" laid down by Deng Xiaoping, but also to modernize institutions, as was the conception of reforms of the Party and state leadership system put forward by Deng Xiaoping. The CPC needs a second strategic transition, that is, a transition from economic development to institution building. The reasons are as follows.

First, economic development is no longer the central task of the CPC, as the roles of the Party and government have undergone great changes, changing from macro-economic "controllers" and "planners" to "directors" and "leaders." It is correct to say that the CPC and the government have always played a vital role in pushing forward China's economy at a high speed, promoting rapid social evolution, maintaining social stability and persisting in opening up to the outside world. But with the rapid development of the economy and deepening of economic restructuring, enterprises, domestic and foreign investors, peasants and consumers have become the main players in the economy. The replacement of the planned economy by a market economy has made it possible for the government to withdraw from the area of competition. The proportion of the state sector in the economy is dropping and the proportion of non-state 


\section{6}

sectors are rising and even exceeding that of the state sector. It would be falling far behind the changes in the economic system if the CPC and the government continue overall control and excessive involvement in the economy. Continuing the strategy of taking economic development as the central task would result in excessive intervention in micro-economic activities and there would be people who would create all kinds of economic rents and political rents, which are the sources of daily worsening corruption.

Second, taking economic development as the central task cannot automatically ensure long-term peace and stability. For longer than the past twenty years, China has experienced sustained high-speed growth, resulting in unparalleled economic prosperity. But economic prosperity will not necessarily or automatically lead to social equality, social fairness and social stability. Chinese history shows that more often than not, serious social crisis occurs during periods of economic prosperity. The experience of many other developing economies also shows that the growth of inequality and unfairness would suddenly stall, reverse and even collapse due to social crises. At present, China has entered another period of social instability, as evidenced by the biggest flood of lay-offs and unemployment in the world caused by an economic restructuring on the biggest in scale in the world, the most significant disparities between town and country and among different regions; the fastest growth in Gini coefficiency in the world; the most serious corruption in the world and the biggest economic cost caused by it; and the biggest damage to the ecological environment in the world. There are also structurally destabilizing factors in economic and social activities. Sustained economic growth has not dissolved these destabilizing factors. On the contrary, it has reinforced them. Practice over the past two decades shows that economic development and political stability are guaranteed when social justice is ensured (such as in the beginning and middle periods of the 1980s); whereas economic development and political stability are threatened when social justice is sacrificed, as in the latter half of the 1990s. We hold that unequal social distribution is the ultimate root cause of social instability in China. So, curtailing inequality in distribution and correcting social injustice have not only become a problem of ethics but also a social problem that threatens social stability and a political problem that threatens the stability of political power of the state. Economic development is the hard truth, though social justice is also a hard truth. ${ }^{3}$ Persistence in pursuing "common prosperity" is not only the greatest superiority of socialism but also the basis of the legality of the CPC and its government. Whether or not to persist in seeking "common prosperity" and prevent polarization is the crucial mark of success or failure in reform. As early as ten years ago, Deng Xiaoping sounded the warning: "Things would be quite different when indulging in polarization, as that would give rise to national conflicts, regional conflicts and class conflicts and correspondingly the conflicts between the center and localities, which would lead to disturbances." In fact, China has been one of the countries in the world with the biggest income inequality (Gini coefficient), and is more and more likely to become an unequal society. Solutions to the contradictions cannot rely only on 
making the "cake" bigger. What is most important is to build basic systems of the state, including an income distribution system, social security system, transfer payments system, and people's democratic participation system so as to ensure the prevention of polarization institutionally.

Third, taking institution building as the central task requires the modernization of state institutions. The modernization of a country should include at least two major aspects: one is economic modernization, such as modernization of agriculture, industry, science and technology and national defense; the other is institutional modernization, that is, modernization of the basic systems of the country, instituting "good governance," ensuring the maximization of the state interests and the welfare of the whole people. Institution building includes the country's basic systems and "infrastructure facilities." It is highly correlated and complementary to economic development and modernization. To realize modernization of the system of a country is not only the most important objective of a modern country but also a typical national public good. Without modernization of state systems, there would be no way of realizing economic modernization. Over the past half century, economic modernization has been initiated and promoted by CPC and its government but it is still necessary for the CPC and its government to direct and guide and motivate all kinds of main players in economic activities, for it is only up to the CPC and the government to consciously initiate and lead the institutional modernization of China and put it into practice, building a modern society with a high degree of democracy and legal system while making the people's life well-off.

Institutional modernization is a process. It is a long historical process of institutional innovation, systems building and practice according to the national conditions and on the basis of assimilating and borrowing the experience and knowledge about modernized states. It is conducive to lowering the management cost of the country, regulating the interests of different social groups, safeguarding social order and the trading rules necessary for economic activities, carrying out the most extensive income distribution and the accessibility and provision of public services in order to improve the human capital conditions of the people of the whole country. ${ }^{5}$ Institution building is not economic development, but the basic condition for stimulating economic growth and sustainable development.

Fourth, institution building is a major transition in the way the CPC exercises political power. Chinese society has not only experienced economic transition, that is, from a planned economy to a market economy, but also social transition, that is, from an agricultural society to an industrialized society and from a rural society to an urban society. The success of these two kinds of transition depend on voluntary transition and the success of the CPC as the ruling Party. Since 1978, the CPC has realized the first transition, that is, from the rule by revolutionary method to the rule by administrative means and from a revolutionary Party to a developmental Party, a ruling party that makes economic development its main task. The Party is capable of promoting economic development, but lacks the capability of solving social contradictions 
and conflicts. This requires the voluntary second transition required by the economic and social development, that is, from the rule by administrative means to the rule by political means and from direct government (first level) rule to indirect rule. ${ }^{6}$ The principal meaning of the political legality of the Party lies not in the popular support and approval by the people when the ruling party has positively satisfied the interests of the people, but in winning the understanding of the people, who will not rise up to overthrow its rule when it cannot bring positive results to the people and even brings negative and passive results to them. Do not think that making the cake bigger can ease all contradictions or crises. With the marketization and globalization of the economy, the capabilities of the government to control the national economy will become weaker and weaker. If its legitimacy continues to be founded on economic growth, this is no different than trusting its destiny to an outside accidental force.

The history of the CPC shows a historical process of constant innovation, timely adjustment and voluntary reform. The CPC's political program and political orientation have been changing since the founding of New China. It has by and large experienced three important periods: 1953-1957, when the basic program of the Party was industrialization and the socialist transformation of agriculture, handicraft industry and capitalist industry and commerce, which created an upsurge in socialist construction. This is the first period of economic construction. The years 1957-1978, when the CPC changed its basic program into one of "taking class struggle as the key link," was the period of class struggle and the Cultural Revolution. Since 1978, when the Fifteenth National Party Congress of the CPC reversed its basic program to economic development, opened up the second period of economic construction. ${ }^{7}$ We hold that entering the twenty-first century, the Party's program and central task, marked by the Sixteenth Party Congress, should be shifted to building modern state systems to open up an era of institution building.

The transition of the CPC is crucial to the success of social transition, market transition and governmental transition. The internal development model shows that the CPC needs "self-reform, self-innovation, self-transition and selfconstruction." The external challenges indicate that the CPC needs "keen determination in making progress, constant innovation, voluntary transition and strictness in Party building."

\section{The time is ripe for accelerating the building of socialist political democracy}

The basic systems of the state should include at least two major aspects: one is the building of the socialist economic system, that is, the socialist market economic system; the other is the building of the socialist political system, that is, the socialist political democratic system. In reality, the CPC has started institution building and institutional innovation from the Fourteenth National Party Congress when it set the goal of building a socialist market economic system. Over the past ten years, China has made major progress in economic construction 
and now it needs a clear objective in reforming the political system, giving it more strength.

Concomitant with economic reform and opening up to the outside world, China's reform of the political system is different from the political reform (political democracy) of other transitional economies. China's political reform aims at promoting economic development. China has maintained relative political stability and social stability for as long as a whole generation. The core of political stability is the stability of the collective leadership. In the 1980s, China experienced three major personnel reshuffles: Hua Guofeng in 1982, Hu Yaobang in 1986 and Zhao Ziyang in 1989. But Deng Xiaoping played a crucial role in maintaining stability. In the 1990s, the leadership change tended to be institutionalized. But the objectives of reform of the political system are not clear, just as Deng Xiaoping pointed out in 1980 that "there is no fundamental change in the drawbacks of the leadership system of the Party and state. In some aspects, the political reform has not only made no progress but regressed. Besides, corruption has become increasingly outstanding with each passing day, which has become a serious hidden trouble and the biggest social pollution." Compared with economic development, political development is relatively slow. Compared with reform of the economic system, reform of the political system has been left far behind. Compared with opening up, the competition mechanism of the survival of the fittest has not been established in the Party, the government and the People's Congress and other power organs. In a word, the current political system has seriously hampered economic transition and the establishment of the socialist democratic system. It has become the biggest institutional bottleneck. To reform the Party and state systems is the core of the construction of a political system and also a fundamental principle for China's modernization (economic modernization and institutional modernization). It should, therefore, become the central task of the Party.

The political report to the Twelfth National Party Congress at the beginning of reform put forward not only the objectives of economic construction but also the objectives for institution building as it said that the building of a high degree of socialist democracy is the fundamental objective and one of the fundamental tasks of the CPC. But the latter has never been listed in the central work and priority tasks of the CPC. Institution building has been left far behind economic construction and development of democracy has been left far behind economic development.

To build a socialist political democratic system should be one of the main themes in the reform of the political system. Just as the market economy is not the "patented good" of capitalism, neither is political democracy that of capitalism. Socialism can promote political democracy just as well. Deng Xiaoping once said that without democracy, there would be no socialism or socialist modernization. The building of the basic systems of the state is to build a socialist political democracy and other basic systems that ensure the long-term peace and stability of the country. 
We may say that the Fourteenth and Fifthteenth National Party Congresses laid down the institutional framework for building a socialist market economy and the Sixteenth National Party Congress put forward a new institutional conception of how to build a socialist political democratic system.

We deem the time to be ripe for accelerating the pace of building such a system. To build a high degree of socialist democracy is not a dream. This manifests itself in the following: First, it is already more than twenty years since China introduced economic reform. The CPC has accumulated a wealth of experience in handling the relations between reform, development and stability and has built fairly mature theories about it. Reform is a process of constant practice and learning. The experience and knowledge of leaders learned in economic reform, in particular, provide some of the most favorable conditions for promoting and directing the reform of the political system, which may help avert major policy decision blunders and social turmoil. Secondly, China's economic development has prepared good foundations for the reform of the political system. China's macro-economy is now in a most stable period, without inflation, without fluctuation, which serves as a good basis and environment for carrying out political reform. Thirdly, the historical experience and lessons of the former Soviet Union and Eastern European socialist countries in political reform have enabled state leaders and people to understand that the best option is to maintain social stability and adopt incremental reforms. Fourthly, the reform of the political system is a matter of major importance that we have wanted to do for years but lacked the necessary conditions and capabilities. It directly concerns the future of China.

What should be the objectives of building a socialist political democratic system? Deng Xiaoping once put forward three objectives and criteria in 1980, that is, catching up with capitalist countries economically; creating a democracy that is higher and more practicable than that of capitalist countries; and training more outstanding personnel than these countries.

The report to the Thirteenth National Party Congress in 1987 put forward the near- and long-term goals for the reform of the political system. The longterm goal is to build a socialist political system with a high degree of democracy, a perfect legal system, efficiency and vitality. The near-term goal is to build a leadership system useful in raising efficiency, enhancing vitality and in motivating initiatives in all quarters, that is, separating the Party from the government, further delegating powers, reforming government agencies, reforming the personnel system, building a socialist social consultation and dialogue system, improving a number of systems for socialist democratic politics and strengthening socialist legal construction. It stressed the limitation of the near-term goal. But the pity is that the ensuing party congresses did not pursue the concrete goals of political reform; neither did they work out a policy timetable.

We hold that, based on actual national conditions, the long-term goal for the reform of the political system should be set at building a socialist political democratic system and, on the basis of the goals set by the Thirteenth National 
Party Congress, we must add the goal of broad participation. At the same time, it is necessary to set more achievable limited near-term goals, such as making policy decisions more scientific and democratic; avoiding major policy blunders; realizing horizontal and vertical restrictions in power in order to prevent over-concentration and abuse of power; realizing the broadest possible people's democracy and ensuring the people's participation in the handling and discussion of state affairs and exercising democratic supervision over and assessment of the performances of the Party and government; building transparent, open and perfect leadership organs of the Party and state and a personnel system and providing incentives for internal competition among different departments and working personnel, making them capable of working both at the top and down below.

\section{Basic contents of institution building}

The modernization of state systems in the twenty-first century is a process of institutional transition and institutional innovation. This includes at least two aspects: one is how to build a socialist democratic system, which is a process of political democracy; the second is state building that is compatible with the system of a socialist market economy and complementary to economic globalization. The basic purpose is to design a basic conception that ensures people's democracy and state building institutionally. This includes five major objectives of institution state building and eight mechanisms of institution building and four major political reforms for institutional changes.

The five major objectives of state building: What is state building? We hold that state building is to prepare the institutional conditions, environment and functions that would ensure good governance, and the ultimate goal of good governance is to maximize state interests and the welfare of the whole people and to ensure the representation and realization of the fundamental interests of the people. For China, the five fundamental objectives are: state security and territorial integrity; economic development and economic stability; social justice and security of the people; political transparency and probity and social stability; ecological balance and environmental protection. The five objectives are interrelated and none can be dispensed with. The realization of one objective must be in tandem with other objectives. The five objectives interact on one another and complement one another. The realization of one objective is conducive to the realization of the other.

A country is a "mechanism" which monopolizes the lawful use of coercive powers that are exercised by the society formed by a given territory and the residents in the territory. ${ }^{8}$ However different in ideology and political power, all states are in essence institutional arrangements of public power. ${ }^{9}$

The basic systems of a state include the following eight mechanisms: coercive mechanism; uptake mechanism; common understanding mechanism; regulatory mechanism; coordination mechanism; expression mechanism; integration mechanism; and redistribution mechanism. 


\section{Coercive mechanism}

The government of a modern state must have a regular army to defend its sovereignty and territorial integrity. If the armed forces of a government do not have a monopoly power, there would be fighting among different warlords. A modern state must have a well-trained and well-disciplined police force to maintain law and order. The army and police must be fully provided for by the state finance. They are not allowed to go into businesses or collect fees. Otherwise, the capabilities of the army to defend the country and the capacities of the police force in maintaining law and order would be greatly weakened or even become destabilizing factors.

\section{Uptake capability mechanism}

The financial capabilities of mobilizing and exploiting social resources so as to provide basic public goods and public services to the society are of the basic functions of the state.

\section{Common understanding mechanism}

The existence of a country and a political system must be based on a common understanding of some basic values. The most important values are identification and loyalty to the national state, which must respect and protect the rights of the citizens. The core value reflects the common ideas and the crystallization of the convictions of the people. What needs pointing out is that core values are never spontaneous, but are conceived and spread consciously by the state. Once formed, such core values can greatly reduce the cost of state management or the cost of governance and can increase the efficiency of implementing public policy.

\section{Regulatory mechanism}

Asymmetry of information and powers are universal in economic and social activities. Asymmetry of information between doctors and patients is likely to lead to a sharp rise in medical fees; asymmetry of information between forgers and consumers would create a glut in the market of forged and shoddy goods; asymmetry of power between the boss and his workers would lead to deterioration of working conditions and the frequent occurrence of work injuries. A state must, therefore, standardize economic behavior and social behavior.

\section{Coordination mechanism}

Government functionaries and government agencies are necessary, but they themselves may entail many problems, such as being unable to live up to their jobs or seeking personal gain by abusing their powers. The central government agencies and local governments may resort to departmentalism or localism. A 
modern state must, therefore, establish a standard public service system and an honest government system to ensure quality and probity of their personnel and must set up all kinds of rules and regulations to ensure that all departments and governments at all levels exercise administrative powers according to law and safeguard the unification of the state machine.

\section{Expression mechanism}

With the rise in educational levels and the increase in information flow, people have enhanced their desire and power to participate in politics. In face of the demand for popular participation, the government must establish institutionalized channels of expression. Otherwise, such demand is likely to be expressed by ways other than institutionalized and peaceful means.

\section{Integration mechanism}

The aspirations and opinions expressed by the people are often many and various. In order to reflect the voices of the people in public policies, it is necessary to integrate the popular views through political parties and other mechanisms (trade unions, Chinese Political Consultative Conference and people's congresses).

\section{Redistribution mechanism}

Under market economy conditions, due to various reasons (such as handicaps, seriously illness, work injuries, unemployment and old age), there might be wide variation in economic life and uncertainties in social life. In order to reduce the sense of insecurity and narrow the inequality caused by primary distribution, the state must, through laws and administrative means, draw on economic resources from the national income and redistribute the results of the primary distribution based on the idea that all citizens, irrespective of residence, profession, gender, educational level and age, so that all members of the society share the results of economic development and social progress.

The preceding eight mechanisms show that China is still facing the tasks of institution building or reconstruction of the state systems. This will not only be favorable for settling all kinds of social crises but will also lay a solid institutional foundation for introducing democratic politics. We shall provide a series of systematic study reports on the necessity and feasibilities for the institutional building in the eight aspects. ${ }^{10} \mathrm{We}$ shall publish other reports in the next few months.

\section{Four political reforms}

The establishment of the basic state systems and the reform of the political system are highly complementary to each other. To establish a socialist democratic 
political system requires political reforms in four major areas, namely, reform of the CPC, reform of the people's congresses, reform of the government and reform of the justice system. The reforms in the four major areas interact upon and reinforce each other.

\section{Reform the CPC}

The CPC is facing a series of challenges that are unparallel in history, very grave and mutually associated. ${ }^{11}$ First of all, the Party is seriously divided in diversified interests, giving rise to many people with vested interests and vested interest groups. This is a period in which an unhealthy tendency within the Party is rife and corruption is the most serious for the past eighty years. The Party is facing a period of grave danger, of accelerated degeneration. The root cause is the lack of de facto democratic and open supervision and a strict control mechanism and system. Secondly, this is a historical period in which the relations between the Party and the people and between the government and the people are the most strained, which seriously corrodes and weakens the foundation for the Party to exercise its political power and the legitimacy of the government. The Party and its organizations have seriously estranged themselves from the people as the interests of the people are not fully reflected in the resolutions and policy decisions of the Party. On the contrary, such resolutions and policy decisions have been strongly influenced by groups of vested interests. When the immediate interests of the people are harmed, they cannot obtain effective protection or timely compensation. On the contrary, the groups of vested interests and monopolistic groups are protected or occupy dominant positions. Lastly, the Communist Party of China has long been facing tremendous external pressure in exercising its political power. We must be fully aware of the fact that the essence of economic globalization is the globalization of capitalism or the economic, political and cultural globalization of capitalism. The Western countries headed by the United States have always had economic and military "hard hegemonism" as well as information and ideological "soft hegemonism." The basic pattern of the world is no longer "the east wind prevails over the west wind" but "the west wind prevails over the east wind." So long as the CPC is in power and so long as China persists in its socialist road, we shall be in a "passive position of being attacked" and in a relatively isolated position.

The most important strategy for coping with the real challenges from both inside and outside is to take the initiative to reform itself.

The objectives of the reform of the CPC should be: establish a true democratic ruling Party that represents the fundamental interests of the overwhelming majority of the people. China's reform first of all requires the reform of the CPC, and the reform of the CPC must be based on the democratic principle so as to become a truly democratic ruling Party. The democratic system of the Party can ensure that the Party represents the fundamental interests of the overwhelming majority of the people and governs the Party according to its constitution. 
The CPC is a ruling Party. The establishment of a democratic system in China depends on the establishment of an inner Party democratic system. From the day of the birth of the CPC, it was clearly determined that it should build an inner Party democratic system. It is, therefore, a political party with a democratic tradition. But over the history of more than eighty years, Party leaders violated the inner Party democracy on many occasions, for which the Party paid the political price. The Party constitution has clearly provided that the democratic nature and democratic system of the Party is the basic system that ensures that the Party represents the maximum interests of the people in wielding political power, and prevents the degeneration of the Party's organs, dictatorial actions of Party leaders and corruption of Party officials. But the reality is far from what is provided in the constitution, or the words and actions do not match. The core of the principle of managing the Party strictly is to abide by the constitution. Even the revision of the Party constitution should be done according to the procedures clearly provided in the constitution. ${ }^{12}$

First, according to the democratic principle clearly provided in the Party constitution, the National Congress of the Party and the Central Committee of the CPC must have clear new democratic decision-making procedures so as to ensure the formation of the most authoritative and concessionary political principles and policies, to ensure that Party representatives fully discuss and debate problems of major importance without interference from the outside (as in closed-door discussions) so as to provide opportunities to express all kinds of opinions (such as conference bulletins and internal information exchanges, which are good information sharing channels), to ensure that representatives and CPC central committee members freely speak their minds without fear of punishment or personal attacks against people who express different points of view. There must be a strict ban on political persecution of any description.

Second, Article 16 of the Party constitution provides: "In taking decisions, Party organizations must implement the principle of the minority being subordinate to the majority." The term "Party organizations" should include the CPC Central Committee, the Political Bureau of the CPC Central Committee, and the Standing Committee of the Political Bureau of the CPC Central Committee. Party resolutions should be adopted or vetoed by secret ballot and by overwhelming majority of the CPC Central Committee members and Party member representatives. If necessary, the results of voting should be made open within the Party. The different opinions of the minority should be given full review. If disputes arise on major issues and the number of people on both sides is very close, except in emergency situations, decisions should be taken according to the views of the majority of the representatives, or decisions should be postponed to allow more investigations and study and exchange of views for discussion at the next meeting as provided in Article 16 of the Party constitution. What needs to be clarified is that resolutions that are not voted for but get the approval of the majority should not be made Party resolutions. If such a resolution is the proposal of some leaders, it may be reserved or left for discussion next time, but it cannot be regarded as the resolution of the Party. 
Third, it is necessary to intensify the two-way democratic supervision system from top to bottom and from bottom to top. In the past, stress was laid in the inner Party supervision of local Party organizations by the Central Committee and this is very necessary. However, we should also stress the inner Party supervision from bottom to top according to relevant provisions of the Party constitution. This includes the democratic supervision by the Political Bureau of the CPC Central Committee over its standing committee, the democratic supervision of the Political Bureau of the CPC Central Committee by the CPC Central Committee and the democratic supervision of the CPC Central Committee by the National Congress. Apart from the functions and powers of the National Congress as provided for by the Party constitution (six in all), it is necessary to clearly define the functions and powers of the plenary session of the CPC Central Committee, which should include hearing and reviewing and voting on reports by the Political Bureau of the CPC Central Committee or its standing committee; hearing, examining and voting on the report by the Central Discipline Inspection Commission, hearing, examining and voting on the report by the Organizational Department of the CPC Central Committee; discussing and deciding on matters of major importance concerning the Party; co-opting or re-electing members to the Political Bureau of the CPC Central Committee and members of the CPC Central Committee, and co-opting or reelecting members to the Central Discipline Inspection Commission. The plenary session of the CPC Central Committee should make normal changes and adjustments to personnel according to the provisions of retirement age, needs of work and requirements for exchange of cadres. During the plenary session of the CPC Central Committee, CPC Central Committee members and alternate members and observers should give objective comments and positive suggestions with regard to the reports by the CPC Political Bureau, the Central Discipline Inspection Commission and the CPC Organizational Department. In order to maintain the principle of "correctly carrying out criticism and self-criticism in the political life of the Party" as provided for by the General Principles of the Party constitution, it is necessary to formulate procedures and implementation rules for carrying out criticism and self-criticism in the Political Bureau of the CPC Central Committee, the National Congress of the CPC and the CPC Central Committee to make them institutionalized and regular and, if necessary, they should be published inside the Party (Party Congresses at all levels and all Party committees should follow the above-mentioned practices).

Fourth, it is necessary to provide institutionally the terms of offices and retirement age for Party leaders. The core of the reform of the Party is the normalization and institutionalization of the leadership change so as to ensure relative stability of the leading groups and at the same time realize the institutionalization of the succession procedures for Party leadership and ensure the continuity of the Party's line and principles. First of all, it is necessary to clarify the functions, powers and term of office of the Party General Secretary and the procedures for election when the post is vacated. As the CPC is a ruling Party, the term of office of Party General Secretary should be the same as the President 
of the People's Republic of China as provided for in the state constitution and the extension of the terms should not exceed two terms. Apart from the provisions of Article 21 of the party constitution that "the General Secretary is responsible for calling meetings of the Political Bureau of the CPC Central Committee and its standing committee and presides over the work of the secretariat of the CPC Central Committee," it should also provide for the specific functions and powers of the General Secretary so as to make him a leader with limited rather than unlimited powers. It should also provide for the procedures to follow when the post of the General Secretary is vacant. Secondly, there must also be a limit on the terms of office for members of the Political Bureau of the CPC Central Committee and members of the Standing Committee of the Political Bureau of the CPC Central Committee. The terms of office should not be too long, so as to enhance the liquidity of the leading body, which is conducive to maintaining the innovative power and vitality of the collective leadership of the Party. Thirdly, the retirement age for central leaders should be clearly defined. In 1982, the CPC Central Committee clearly stipulated the retirement age for provincial and ministerial level officials (including deputies). Now it is necessary for the central leadership to clearly define the retirement age so that it would become normal for leaders to retire at the prescribed age and ensure the institutionalization and stability of leadership change.

Fifth, it is necessary to prevent any leader from exercising individual autocracy and to ban any form of personality cult. The CPC is a unified entity that has been organized according to the principle of democratic centralism and it exercises a high degree of centralism on the basis of a high degree of democracy. Article 16 of the Party constitution provides: "Any Party member, irrespective of official ranking, cannot make decisions on issues of major importance" and "it is not allowed to exercise individual autocracy and put individuals above Party organizations." Article 10 of the Party constitution provides: "The Party bans any form of personality cult and it is imperative to ensure that the activities of Party leaders are subject to supervision by the Party and people and at the same time safeguard the prestige of leaders that represent the interests of the Party and people." It is, therefore, necessary to incorporate into the Party constitution the following provisions made at the second plenary session of the Seventh CPC Central Committee: "Celebration of the birthdays of Party leaders is forbidden. Naming places, streets and enterprises after Party leaders is likewise forbidden. We must keep to our style of plain living and hard work and put a stop to flattery and exaggerated praises." ${ }^{13}$ It should also be added that Party leaders are not allowed to write inscriptions in their personal names and the signatures of Party leaders on public buildings and public places should be treated properly. There should also be clear stipulations about the rules governing foreign visits and internal inspections by Party leaders. The TV coverage (national news program) of Party leaders should be strictly defined, with necessary restrictions. Except for major events or major political problems, there should be no report or they should be reported briefly. 
Sixth, it is necessary to stick to the principle that "party leadership is chiefly political, ideological and organizational leadership" as stipulated in the General Program of the Party Constitution, to redefine the relationship between Party and administration and introduce political rule and let the Party withdraw from administrative areas to intensify the management functions of the government, and to encourage social participation and introduce a new type of "social governance." At the central level, it is good for the Party general secretary to concurrently take up the post of the president of the state; at the local levels, local Party secretaries take up the post as chairman of the local people's congress at the same level. This is conducive to the Party exercising leadership and supervision over the government. The Party does not participate in the handling of specific administrative affairs but represents the people in exercising political power and supervising the government through the constitution and law and other means and through the institutional arrangement of the People's Congress. For instance, Article 92 of the Constitution of the People's Republic of China provides: The State Council is responsible, and reports on its work, to the National People's Congress or, when the National People's Congress is not in session, to its Standing Committee.

\section{Reform of the National People's Congress (NPC)}

The second task of China's political reform is to change the system of the NPC standing committee to make the "rubber stamp," "political home for the aged" a people's democratic policy decision-making system that is true to its name. First of all, there is serious discrimination against the rural population in the distribution of the number of people's deputies. There is one rural people's deputy for every 960,000 rural people while there is one people's deputy for every 260,000 urban people, four times that of the rural areas. This has not only violated what is stipulated in Article 33 of the constitution, that is, "all citizens of the People's Republic of China are equals before the law," but also violates Article 34 of the constitution, that is, "All citizens of the People's Republic of China who have reached the age of 18 have the right to vote and stand for election, regardless of nationality, race, sex, occupation, family background, religious belief, education, property status, or length of residence, except persons deprived of political rights according to law." In addition, it has created differences in the number of people's deputies per one million people, with areas with a high proportion of urban population, such as Tianjin, Beijing and Shanghai, having more people's deputies per one million people, and rural areas where the proportion of one million people is less, such as Henan, Hebei and ten other provinces (see Table 12.1) having fewer deputies. The unequal distribution of political resources with regard to the number of people's deputies has a direct bearing on the unequal distribution of economic resources. We have found that the per capita transfer payments in various areas are closely associated with the number of people's deputies per one million people. 
Table 12.1 Number of people's deputies per one million persons in various areas (2000)

\begin{tabular}{|c|c|c|c|}
\hline & $\begin{array}{l}\text { Total population } \\
(10000)\end{array}$ & $\begin{array}{l}\text { Number of deputies } \\
\text { per million persons, } \\
\text { Ninth NPC }\end{array}$ & $\%$ \\
\hline National & 126583 & 2979 & 2.35 \\
\hline Beijing & 1382 & 59 & 4.27 \\
\hline Tianjin & 1001 & 45 & 4.5 \\
\hline Hebei & 6744 & 120 & 1.78 \\
\hline Shanxi & 3297 & 68 & 2.06 \\
\hline Inner Mongolia & 2376 & 57 & 2.4 \\
\hline Liaoning & 4238 & 116 & 2.74 \\
\hline Jilin & 2728 & 72 & 2.64 \\
\hline Heilongjiang & 3689 & 105 & 2.85 \\
\hline Shanghai & 1674 & 67 & 4 \\
\hline Jiangsu & 7438 & 151 & 2.03 \\
\hline Zhejiang & 4677 & 89 & 1.9 \\
\hline Anhui & 5986 & 112 & 1.87 \\
\hline Fujian & 3471 & 64 & 1.84 \\
\hline Jiangxi & 4140 & 79 & 1.91 \\
\hline Shandong & 9079 & 185 & 2.04 \\
\hline Henan & 9256 & 163 & 1.76 \\
\hline Hubei & 6028 & 126 & 2.09 \\
\hline Hunan & 6440 & 119 & 1.85 \\
\hline Guangdong & 8642 & 166 & 1.92 \\
\hline Guangxi & 4489 & 90 & 2 \\
\hline Hainan & 787 & 18 & 2.29 \\
\hline Chongqing & 3090 & 58 & 1.88 \\
\hline Sichuan & 8329 & 151 & 1.81 \\
\hline Guizhou & 3525 & 66 & 1.87 \\
\hline Yunnan & 4288 & 88 & 2.5 \\
\hline Tibet & 262 & 20 & 7.63 \\
\hline Shaanxi & 3605 & 67 & 1.86 \\
\hline Gansu & 2562 & 46 & 1.8 \\
\hline Qinghai & 518 & 19 & 3.67 \\
\hline Ningxia & 562 & 18 & 3.2 \\
\hline Xinjiang & 1925 & 59 & 3.06 \\
\hline Army & 250 & 268 & 107.2 \\
\hline
\end{tabular}

Source: Numbers of People's Deputies is from http://www.peopledaily.com.cn/item/lianghui/zlhb/ rd_9.htm. Population of various areas is from National Statistics Bureau, China Statistics Yearbook 2001, Beijing: China Statistics Press, 2001.

Secondly, the current National People's Congress lacks broad representation as it has become more and more elite both politically and intellectually and less and less connected to the common people and the workers and peasants. The changes in the makeup of the people's deputies of all National People's Congresses show that the proportion of communists in the Ninth NPC was as high as 71.3 percent versus only 54.48 percent in the First NPC; the proportion of cadres and intellectuals and their combination rose to 33.2 percent, 
21.1 percent and 54.3 percent from 13.38 percent, 14.96 percent and 28.34 percent in the Fifth NPC; the proportion of workers and peasants and their combination dropped from 26.71 percent, 20.59 percent and 47.3 percent to 10.8 percent, 8.0 percent and 18.8 percent (see Table 12.2).

Thirdly, the current standing committee of the NPC is more and more like a "political home for the aged" for senior Party and government officials. Article 65 of the constitution provides that "The Standing Committee of the National People's Congress is composed of the following: The Chairman; The ViceChairmen; The Secretary-General; and Members. Minority nationalities are entitled to appropriate representation on the Standing Committee of the National People's Congress. The National People's Congress elects, and has the power to recall, all those on its Standing Committee. No one on the Standing Committee of the National People's Congress shall hold any post in any of the administrative, judicial or procuratorial organs of the state." However, most of the members, chairmen, vice-chairmen and the Secretary General of the NPC Standing Committee and the chairmen and vice-chairmen of the sub-committees had served in state administrative agencies, judicial organs and procuratorial organs and most of them are above the retirement age as provided by the CPC Central Committee in 1982. Such non-institutional arrangements (not nominated and elected by people's deputies) lack proper representation (especially of the peasants who make up two-thirds of the national population) and at the same time have weakened the abilities of the NPC to supervise the government.

As the basic political and democratic institution of the People's Republic of China and also the foundation for a transparent political system, the National People's Congress bears the fundamental tasks of representing the people and fully exercising its democratic power to supervise the government, to restrict the government and to help realize good social governance and to fight serious corruption within the government.

Reform of the NPC and its standing committee must occur within the system provided by the basic principles of the Constitution of the People's Republic of China. The objective of reform is to genuinely establish people's democratic policy decision-making mechanisms, not in name only, so as to give effect to the established provisions for supervision and restriction of the government by the NPC, and to win the trust of the people in implementing, protecting and defending the constitution. The NPC must become the true representative of the people instead of a "club for political and intellectual elites" or the retreat for senior Party and government officials after retirement.

It is, therefore, necessary to distribute the number of people's deputies equally. According to the provisions of Article 33 of the constitution, "All persons holding the nationality of the People's Republic of China are citizens of the People's Republic of China. All citizens of the People's Republic of China are equal before the law. Every citizen enjoys the rights and at the same time must perform the duties prescribed by the Constitution and the law." Further, the rural population should receive "national treatment" and all discriminatory provisions against the rural people should be scrapped and there should be introduced, 


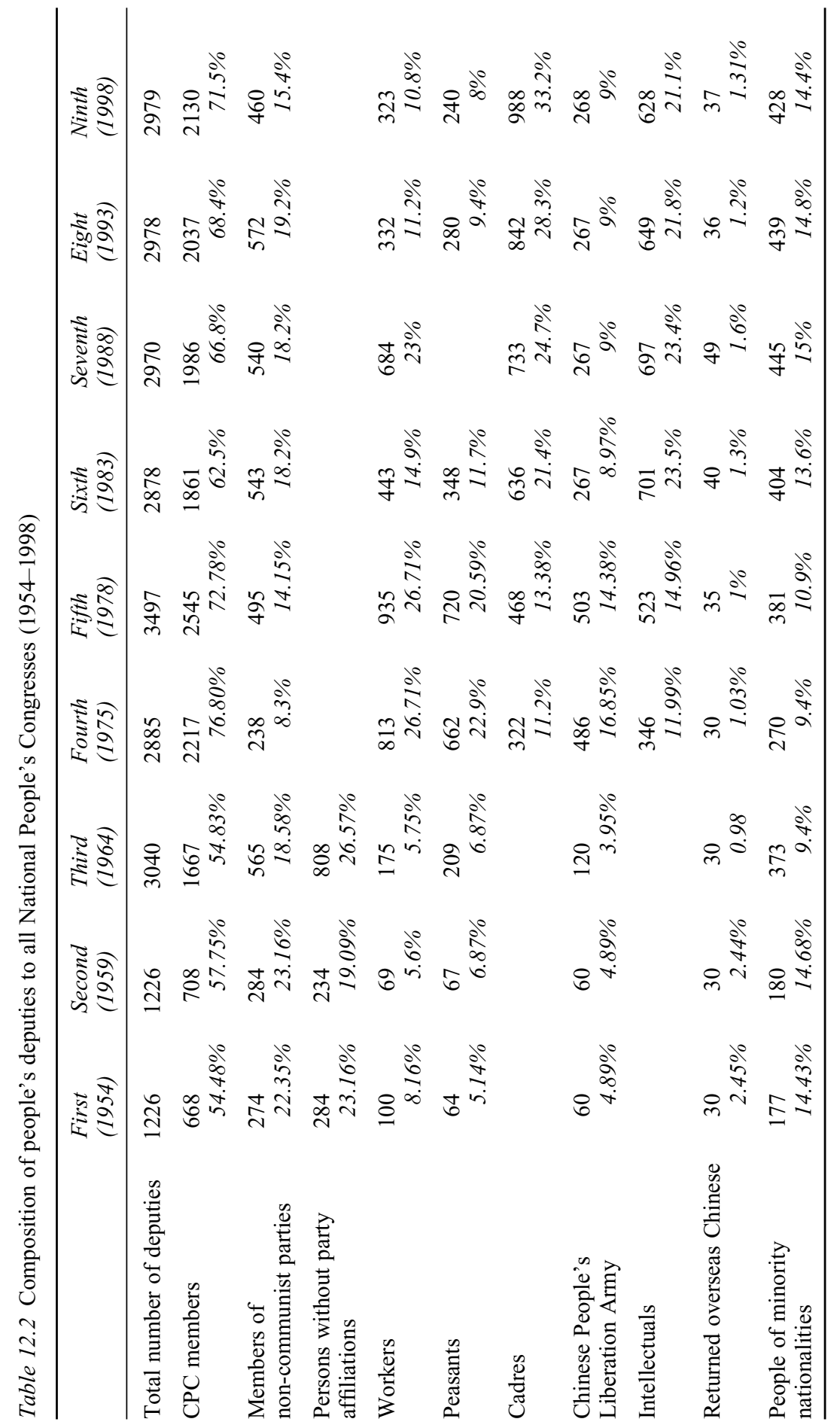




\section{2}

instead, urban-rural unified, equal, open and democratic elections. According to the provisions of Article 34 of the constitution, "All citizens of the People's Republic of China who have reached the age of 18 have the right to vote and stand for election, regardless of nationality, race, sex, occupation, family background, religious belief, education, property status, or length of residence, except persons deprived of political rights according to law," and, further, peasantworkers in urban areas, whether temporary or resident, should all have the equal right to vote and stand for election.

Second, the national people's deputies should have broad representation and it is necessary to increase the proportion of people from all walks of life. The preamble of the constitution clearly says: "In building socialism it is imperative to rely on the workers, peasants and intellectuals and unite with all the forces that can be united." And Article 2 provides: "All power in the People's Republic of China belongs to the people." In order to reflect the basic principles of the constitution, more workers, peasants and other laboring people should serve as people's deputies to the National People's Congress and there should be fewer CPC members, reducing it to 54.48 percent as in the first NPC. There should be control of the deputies from non-communist parties (the proportion of deputies from these parties has reached 15.5 percent while the total population of these parties makes up less than 1 percent). Their proportion should be controlled at a percentage only slightly higher than the proportion of their population. There should be fewer deputies from cadres and intellectuals. The proportion of people's deputies from the army should be cut sharply (their proportion is one per 10,000 people), with the number of deputies achieved by these cuts to be distributed among other population groups.

Third, according to the provisions of Article 65 of the constitution, "No one on the Standing Committee of the National People's Congress shall hold any post in any of the administrative, judicial or procuratorial organs of the state," and members of the NPC standing committee shall not be those who hold administrative, investigative or procuratorial posts after retirement. Article 56 provides that "the National People's Congress elects and has the right to remove members of the NPC standing committee" and specifies how to elect and how to remove NPC standing committee members. NPC standing committee members should be elected directly by the people's deputies and the proportions of the number of nominees should be expanded. NPC standing committee members should be full-time rather than half-time. During their tenure, they should be independent of their original units and should enjoy the allowances and benefits provided by the state. Their term of office should not be more than two years and they should make open commitments to the state and the people.

Fourth, Article 73 of the constitution provides: "Deputies to the National People's Congress during its sessions, and all those on its Standing Committee during its meetings, have the right to address questions, in accordance with procedures prescribed by law, to the State Council or the ministries and commissions under the State Council, which must answer the questions in a responsible manner." The provisions need to be specified. For instance, the NPC Standing 
Committee or its sub-committees should address questions to leaders of government ministries and commissions no less than one time per year and should vote on the report on the questioning. When necessary, the questioning sessions should be open to the national people's deputies or the public or broadcast live by radio and TV so that the people of the whole country can have the right of information just as NPC standing committee members. The people's government should put the results of their policies and programs and their implementation under the supervision of the people.

Fifth, in order to implement the provisions (9) and (10) of Article 62 of the constitution about the powers and functions of the NPC "to examine and approve the plan for national economic and social development and the reports on its implementation," "to examine and approve the state budget and the report on its implementation" and the provisions (5) of Article 67 about the functions and powers of the NPC Standing Committee to "examine and approve the state budget and the report on its implementation," it is necessary to clarify the procedures, rights, obligations, agenda and agenda of questioning for the examination and approval of the national economic and social development plans and budget and final account by the NPC and its Standing Committee. The key to erasing its image as a "rubber stamp" lies in the right of examining and approving the fiscal and investment appropriations as clearly provided for in the constitution, including vetoing and non-approval. The members of the NPC's financial and economic committee and budget committee, apart from central representatives, should have one member from each province and each province have one vote and final decisions should be taken according to majority vote on major investment projects and investment amounts put forward by the state planning commission. The distribution plan for transfer payments and tax collection should be, according to the provisions of Article 62 of the Constitution, submitted to the annual NPC session for examination and approval. The NPC has the right to examine and approve major expenditure projects, investment estimates for trans-provincial major projects, the expenditure budget, project schedule and quality, project management and returns. Sub-committees of the NPC Standing Committee have the right to examine and approve relative state projects and report them to the NPC and, if necessary, to reveal the projects to the whole country so as to subject major public spending and public projects to supervision by the people.

Sixth, apart from the Supreme People's Procuratorate and the Supreme People's Court, which must report to the NPC on their fight against corruption, all anti-corruption organizations of the government, such as the Ministry of Supervision, the Ministry of Justice, the Auditing Office, the Ministry of Public Security and the Ministry of State Security, should report on the progress of major measures against corruption in all fields of endeavor to the NPC Standing Committee or its law sub-committee, which should designate a special group to examine and discuss the reports. The reports to the NPC by the State Planning Commission and the Ministry of Finance should have greater content on the fight against corruption. 
Article 71 of the "Constitution of the People's Republic of China" provides: "The National People's Congress and its Standing Committee may, when they deem it necessary, appoint committees of inquiry into specific questions and adopt relevant resolutions in the light of their reports. All organs of state, public organizations and citizens concerned are obliged to supply the necessary information to those committees of inquiry when they conduct investigations." It is necessary to make timely investigations into major corruption cases, especially at the higher levels of government, major accidents, major economic costs and major destabilizing events and make corresponding resolutions and timely reports to the NPC and its Standing Committee and publish them. Citizens who have provided related materials during investigations should be rewarded and their personal safety should be protected.

Seventh, members of the NPC Standing Committee and people's deputies must declare their personal and family income sources, assets and liabilities as they actually occur and accept open supervision and auditing. They must take an oath and make a written guarantee to the state and the people that they will not accept any forms of bribes and will not receive, collect, provide or actually enjoy any property and benefit from any person or organization. Otherwise, they shall be regarded as having violated the law and their qualifications as people's deputies shall be terminated automatically or they shall be dismissed.

Eighth, the NPC Standing Committee and people's deputies should have their personal open websites to hear the views of the public and know what the public suggests and should intensify their ties with the public so as to create a situation of mutual action between the people's deputies and the public and to make people's deputies truly mirror the will of the people as their title suggests.

\section{Reform of the government}

The objectives of the reform of the government are to enable the unlimited government to become a limited government, to clarify the functions and powers that are not clear enough in order to become a truly responsible government, to enable an invisible government to become a visible government, to enable a government that intervenes too much to become a government that provides services and has a public finance system and simple and streamlined administrative examination and approval systems and an information provision and disclosure system.

The state auditing organ must intensify its independent auditing and supervising functions. Article 91 of the constitution provides: "The State Council establishes an auditing body to supervise through auditing the revenue and expenditure of all departments under the State Council and of the local governments at different levels, and those of the state financial and monetary organizations and of enterprises and undertakings. Under the direction of the Premier of the State Council, the auditing body independently exercises its power to supervise through auditing in accordance with the law, subject to no interference by any other administrative organ or any public organization or individual." In order to 
play its role as a watch-dog of the state finances, state assets and resources, the auditing organ must have independence in operations and financial resources.

1 The State Auditing Office should submit an auditing report to the NPC Standing Committee or the NPC and make public the results of auditing and results of punishment;

2 The state should formulate detailed auditing procedures on fiscal spending and state property management and receipts in order to effectively reduce waste, the probability of corruption and possibilities of discovery and formulate regulations on punishments;

3 It is necessary to design a set of procedures for supervision over the use and whereabouts of state property, sources of income, sales or rental of state property in order to ensure that state property and income cannot be appropriated at will or used for other purposes or lie idle;

4 The auditing organ should audit on behalf of the state major government procurement and the use of money for major projects and report to the State Council and the NPC Standing Committee and accept questioning by people's deputies;

5 The state shall ensure the sources of funds for the auditing office and the funds should be appropriated directly by the budget committee of the NPC Standing Committee;

6 The State Auditing Office should have an open website to encourage the citizens and insiders to report irregularities and protect such citizens and insiders;

7 The auditing office should publish its auditing manual, provide detailed technical guidance and information, select and absorb competent and experienced professional personnel. It should entrust well-reputed domestic or foreign certified public accounting offices to undertake auditing of public agencies and large state-owned units to make full use of the resources of professional personnel.

\section{Reform of the judicial system}

The objective of the reform of the judicial system is to establish a relatively independent judicial system to ensure law enforcement.

The establishment of an independent judicial system is one of the important measures against corruption. By independence, we mean relative independence, that is, the financial system should have an independent organization, independent staff, independent sources of overhead expenses, and independent enforcement of law. It is, therefore, recommended:

1 Judicial organs at all levels should be independent of administrative organs at all levels; administrative organs at all levels must respect and ensure the independence of judicial organs at all levels and they must not be allowed 
to interfere in the operation and routine affairs of judicial organs under any pretext.

2 Judicial organs are independent legal organs of the state and they should not follow the administrative grades and benefits of ordinary administrative organs. Instead, they should introduce new judicial organizations and legal personnel systems, such as a procuratorate system, judges system and lawyers system. They should not be incorporated into the administrative organizations. They should independently recruit or remove personnel, openly selecting and appointing upright, capable and well-trained personnel and qualified and experienced people to take up posts for the administration of justice. The selection and appointment of senior judicial personnel should be done nationwide. Before accepting the appointments, people should report to the judicial departments their personal or family income, assets and liabilities. The state should ensure their old-age pension and medical insurance after they retire.

3 Judicial organs at all levels should have their own independent budgets, which shall not be listed in the government budget. The budget should be verified, approved and appropriated by the Budget Committee of the NPC at all levels to ensure that they have enough funds to operate independently. They are strictly forbidden to engage in business activities or other profit-taking activities; they are strictly forbidden to share any funds recovered; judicial organs should have two lines of receipts and expenditure within a limited period of time and report them to the NPC Standing Committee.

It is necessary to clarify the public notice system concerning the appointment and removal procedures and information announcements of pre-appointment. 


\section{Making policy decision-making more scientific, democratic, systematic and specialized ${ }^{1}$}

Reform and opening up have brought about not only high economic growth and tremendous social changes, but also significant changes in the policy decisionmaking mechanism. This indicates a shift from personal policy decision-making to collective policy decision-making and a policy decision-making process with extensive democratic participation, that is, a transition from non-transparent to transparent policy decision-making or from autarkic to open policy decision-making. Such changes reflect a good development trend, with society becoming more and more progressive, politics becoming more democratic and the public becoming more and more open. Thanks to major changes in economic development, social progress and policy decision-making processes, all kinds of think tanks have emerged. Scholars in all disciplines have actively offered their advice. So have I over the past dozens of years.

Why does China need policy decision think-tanks and why does it need to make policy decision-making more scientific, democratic and specialized? One of the biggest lessons over the past fifty years after the founding of New China, I think, is that major policy decision-making has had not only the biggest successes but also the biggest errors. Since the founding of New China, China has experienced three major policy blunders. ${ }^{2}$ The first is the persistence in taking class struggle as the key link and frequent political movements until the Great Cultural Revolution, which delayed the progress of China's modernization. The second is the eagerness for success in the guiding thinking for economic development, which resulted in a number of big rises and big falls, causing serious imbalances of major proportions, forcing major economic adjustments. The third is the blunder in population policy and improper economic policy, which led to blind growth of the population in the 1950s and 1960s. That caused a heavy burden on social and economic development, which will take at least half a century to overcome. Were it not for these big blunders, China's economic development would have been much smoother and more successful.

The "Great Leap Forward" movement and the "Great Cultural Revolution" made China's economy sustain tremendous losses. American China expert R. Terrill held that the turmoil of the Great Leap Forward made China lose eight years in its new Long March toward modernization. ${ }^{3}$ Terrill simulated the two kinds of GDP growth curves under conditions with and without the Great Leap 
Forward to estimate the losses caused by the Great Leap Forward. If calculated by the logarithm according to the 1987 price, the GDP grew at an average annual rate of 4.1 percent from 1952 to 1965 and grew at an average annual rate of 8.6 percent from 1952 to 1957 . The losses brought about by the Great Leap Forward are mainly manifested in the difference between the real growth curve after 1957 and the simulated curve (without Great Leap Forward). The result is: the simulated curve for 1959-1960 was lower than the actual curve, reflecting the fact that the simulated value is lower than the actual value in the economic growth in 1958, 1959 and 1960, which is the result of abnormal expansion. After 1961, the actual curve is much lower than the simulated curve, with that for 1965 being 40 percent lower than the simulated curve. This shows that the losses brought about by the Great Leap Forward, even during the later rehabilitation period, are still lower than the GDP loss of 40 percent in the situation without the Great Leap Forward. According to Y. Kwan and G. Chow, if there had not been the Great Leap Forward and the Great Cultural Revolution, China's economic growth after 1958 would have been quite different from what has actually happened and the results would have been 2.7 times the real value of the supposed output per labor for $1993 .{ }^{4}$

Reviewing the three major blunders, Bo Yibo said: “1958's Great Leap Forward was a response to 1957's Party rectification movement and the antirightist movement and the ensuing 'anti-rightist conservationism' and the Great Leap Forward itself was the result of following closely the political storms in taking economic policy decision-making." The first round of the Great Leap Forward made the national economy nearly "exhausted." Yet, it was decided to continue the great leap forward in 1960 in total disregard of the tremendous difficulties. The continued Great Leap Forward met with grave setbacks, showing clearly the undesirable results of following the political storm in taking policy decisions for developing the economy. He held that an effective way for realizing democratic centralism is to institutionalize the democratic system and put it into the legal code. ${ }^{5}$

Mao Zedong played a central role in the three major blunders. Both successes and failures were attributed to him. This was the Mao Zedong era, during which all major policy decisions were taken by himself. There were big successes and also big failures. This is characteristic of the one-man policy decision-making mechanism. In fact, there were also differences of views at the time, but these views were suppressed and criticized. In the mid-1950s, non-Party economist Ma Yinchu advocated for family planning to control population growth. Deng Xiaoping put forward similar views and Zhou Enlai affirmed their views. But Ma Yinchu fell victim to severe criticism and Deng Xiaoping's views were not adopted either. Peng Dehuai opposed the Great Leap Forward in the late 1950s, but he met with a cruel political struggle. ${ }^{6}$ In 1967, during the peak of the Great Cultural Revolution, Tan Zhenlin and other veterans showed their disagreement with the launch of the Great Cultural Revolution, but for this, they were labeled as the "counter-current of February." In 1975, Deng Xiaoping was suspended ${ }^{7}$ for his opposition to the idea that the Great Cultural Revolution was 70 percent 
a success and 30 percent a failure. This was an era of one-man policy decision-making. Such policy blunders could hardly be avoided, but neither could they be corrected.

Up to the Deng Xiaoping era, the policy decision-making mechanism began to be shifted toward a collective model. Here Deng Xiaoping displayed a positive and crucial role. His work experience as a central leader and his political persecutions during the Cultural Revolution made him more deeply aware than other leaders that the root cause of blunders was not a problem of personal responsibility, but a problem of major defect in the policy decision-making system. He once said: "The mistakes we have made in the past are certainly associated with the thinking and style of work on the part of a certain leader, but what is more important is that there are problems with the organizational system and work rules. If the system is good, it may prevent bad persons from running roughshod; if the system is not good, it makes a good person unable to do good things and even go to the opposite." "It is not that I am not accountable for these blunders. It is the leadership system and organizational system that are of fundamental importance and concern the situation of the whole country and concern stability and long-term effects. Such a system concerns whether the Party and the country would change their colors and it merits the full attention of the whole Party." "At the national soft science work conference on July 31, 1986, the then vice-premier Wan Li was the first to call for more democratic and more scientific policy decision-making. He stressed that leaders must respect the rights of the people to fully air their views and must not be afraid of differences of views or even opposing views and only in the highly free academic atmosphere was it possible to have all good ideas come out. ${ }^{9}$ The Thirteenth National Party Congress in 1987 clearly put forward the long-term goal of the reform of the political system, that is, to establish an efficient and vigorous socialist political system with a high degree of democracy and a perfect legal system. China should not copy the "checks and balances" system of the West or rotating rules by multiple parties, but it should continue its People's Congress system and the multiparty cooperation and political consultation system under the leadership of the Party following the principle of democratic centralism. China should establish a social consultation and dialogue system and open wider the activities of leading organs and let the people know about major situations and have major problems discussed among the people. During their period, apart from the core role of Deng Xiaoping, the collective leadership played an increasingly important role. This was also a period during which major policy decisions were quite successful and even if there were errors, they were corrected in a timely fashion, demonstrating the flexibility and adaptability of policy decisions. The policy decision-making mechanism developed from "one-man decision-making" to "collective decision-making." So, this period may be regarded as "an era for collective policy decision-making."

Since the beginning of the 1990s, the central authorities have become more and more attentive to views from experts of all disciplines. The central leadership time and again stressed the importance of respecting science, respecting 
knowledge and respecting experts," and always heard views from both Chinese and foreign experts in major policy decision-making. This helped to reduce errors and to correct errors in a timely fashion. This period may be regarded as "an era of policy decision-making through consultation."

To make policy decisions more scientific and democratic is a process of institutionalization, standardization and proceduralization. In 1992, the Fourteenth Party Congress stated that to make policy decision-making more scientific and democratic was an important feature of democratic centralism and an important task of building a socialist democratic politics. Leading organs and leading officials must learn to listen to the views of the people and fully recognize the roles of experts in all disciplines and consulting organization so as to accelerate the pace of building a democratic and more scientific policy decision-making system. In 1997, the Fifteenth Party Congress again reiterated the idea of making socialist democracy systematic and codified so that such a system and legal system would not change with the changes in leaders or with changes in the attention of leaders. In 2002, the Sixteenth Party Congress made it more clear how to promote scientific and democratic policy decision-making, calling on policy decision-making bodies at all levels to improve the rules and procedures for making major policy decisions and to establish a system for hearing the opinions of the people. It also introduced the announcement and information systems concerning matters of major importance that are closely associated with the interests of the people, improved the expert consultation system, introduced the policy decision feasibility study system and responsibility system so as to prevent arbitrariness in policy decision-making. All these demonstrate that the realization of more democratic and scientific policy decision-making depends on institution building and enforcement so as to ensure, institutionally, that policy decisionmaking is not arbitrary, thus preventing policy blunders.

I have also gained through my study and experience an understanding as to how to make policy decision-making more democratic and more scientific. In my work China, Toward the 21st Century which was published by the China Environmental Sciences Press in 1991, I advanced the view that the more we know about national conditions, the less error we shall make in making policy decisions; the deeper we have mastered the laws governing development, the fewer setbacks we shall meet.

In 1998, I presented the view that one of the most important aspects of political reform was to change the political policy decision-making, including making it more scientific, democratic and specialized, as well as maintaining the continuity and stability of public policies. This is because from the angle of economics, both macro-economic and micro-economic policies all face one basic problem in terms of either the employment of the market mechanism or decisions taken by the government, namely, the incompleteness of information and uncertainties of risks. Incomplete information may lead to market failure or government failure or policy failure. The purpose of making policy decision-making more scientific, democratic and specialist is to solve the problem of incompleteness of information in the process. National conditions are very complicated and all kinds of 
contradictions are very sharp. The population is large and there are big disparities between different regions. To these we must add rapidly changing external situations for which we have no foresight nor any panacea. What is needed is an institutional guarantee for the scientific, democratic and specialist nature of policy decisions and for the continuity and stability of public policies. This includes high-level think-tanks or advisory committees, which should undertake in-depth studies of some major issues of strategic importance and policy-making, improving the government policy analysis organizations and effectively absorbing outstanding personnel. We must establish policy review organizations and networks to collect data and make a comprehensive national conditions analysis and carry out investigations and assessments of the major policies, provide all kinds of important knowledge and information, encourage internal and open debates on public policies concerning the interest of all quarters, and increase the transparency of the reports by the news media in the discussion of public policies. ${ }^{10}$ Although this is not the best target model for China's political reform, it is the most suitable model, which may form the self-development and evolutionary logic of China's political reform.

Later on, we went on to put forward the idea of formulating a "State Security Law" and establishing a State Security Commission. The State Security Commission should be led directly by the state president and made up of leaders of departments of foreign affairs, national defense, security, public security, central bank, finance, foreign trade, planning, Hong Kong, Macao and Taiwan. The commission should be put in charge of the short-, medium- and long-term security strategies, programs of action and plans for execution and should handle major breaking events concerning state security and should coordinate the programs of action of all departments. ${ }^{11} \mathrm{We}$ also proposed setting up an economic advisory committee for the premier to study major economic issues and put forward major policy conceptions and issued an annual white paper on economic and social development.

One of the outstanding features of the new government has been to carry out reform and improve the policy decision-making mechanism and make great efforts to make policy decision-making more scientific and democratic. In March 2003, the revised "Rule of Procedures of the State Council" stressed the importance of scientific and democratic policy decision-making and of persisting in conducting administrative affairs according to law and strengthening democratic oversight. The document clearly provides that before the State Council takes any major policy decisions, it must hear the views of and suggestions by democratic parties, people's organizations and experts and scholars and give full scope to democracy. It has let people speak out and absorb what is good so as to prevent errors in policy decisions and make them more scientific and extensively accepted and better implemented.

In fact, the practice started with Premier Zhu Rongji. In February 1998, I wrote the first national conditions report "Create More Jobs for the People: China's Unemployment Problem and Employment Strategy." Zhu Rongji and $\mathrm{Wu}$ Bangguo, who were then vice-premiers, wrote an important note to the 


\section{2}

report. After that, we went on to provide several national conditions reports and related materials to the State Council led by Zhu Rongji. We wrote national conditions reports in order to "get a clear picture of the national conditions, show concern for the people's livelihood, offer our opinions and influence the national policies." Our reports concentrated on problems concerning the people's livelihood, covering such issues as laid-off workers, social security, the income of peasants, the poverty in areas inhabited by minority people, ecology and environmental protection and social equality. These reports have caught the attention of State Council leaders, who made a number of notes. I, myself, attended two expert forums called by Premier Zhu Rongji, where I put forward my policy recommendations. I was deeply impressed with the fact that at the forums, Premier Zhu Rongji encouraged experts to air their views and even debates.

After Wen Jiabao took office as the premier, I attended two expert forums presided over by Wen. Premier Wen Jiabao made several notes to our national conditions reports. I also attended two forums on clean government presided over by Wu Guanzheng, member of the CPC Central Committee and secretary of the Central Disciplinary Commission, at which I stated my suggestions concerning the building of a clean government system.

On April 13, 2003, I wrote an article "Cope with Global SARS Crisis Actively in an All-Round Manner." The second day, I submitted the report to the CPC Central Committee and the State Council. This was the first report on how to deal with the SARS crisis delivered to the CPC Central Committee and the State Council. I put forward a nine-point proposal, which was adopted. By the end of June, I wrote and compiled 32 SARS study reports, providing the policy decision-makers with information, knowledge and recommendations for making policy decisions.

The national conditions reports collected in this book mainly focus on the major challenges to China's development after the Party's Sixteenth National Congress, how to respond effectively and take up challenges, how to deal with the serious losses caused by the SARS crisis and what lessons can be drawn from it. The core is how to understand the new approach to development, how to realize the transition from the first generation of development strategy to the second generation of development strategy. It should be said that the third plenum of the Sixteenth Party Congress for the first time established the new "people first" approach to development, with new strategies for unified development in five major aspects. The significance is no less important than the decisions taken at the third plenum of the Eleventh Party Central Committee twenty-five years ago. It has lent a new line of thought and established a new mechanism for realizing the grand goal and historic mission of building a welloff society that will benefit more than one billion people.

The major contribution that a scholar can make is to offer his knowledge to the state and the people. In 2000, I and Zou Ping jointly wrote the article "Society and Development: Study of the Regional Disparities in Social Development in China" (Zhejiang People's Publishing House). The article gives 
a detailed account of the new "people first" approach to development. In the same year, I and Zou Ping recommended to the State Planning Commission that "people first" should be the guiding thought for mapping out the Tenth Five-Year Plan and Long-Term Development Program. The study laid an academic foundation for coordinated development of the economy and society. During the SARS crisis, on June 17, 2003 I attended the expert forum called by Premier Wen Jiabao on how to strengthen public health so that it would develop alongside social development. I stated my views, which left a deep impression. On July 21, I published my article "On the People-First Approach to Development" in the Liberation Daily in Shanghai. What is gratifying is that not long afterwards, the view I presented was written into the decisions adopted at the third plenum of the Sixteenth CPC Central Committee. Such a situation would have been impossible were it not for the major changes in the policy decision-making process.

What is most important for a scholar is to have the courage to pursue his studies relentlessly for the interests of the state and the people. On June 12, 2002 I wrote the article "The Party's Sixteenth National Congress and Trends in the Future of China," in which I give full stress to the awareness that from now on, China has entered a new stage of political development marked by institutionalization, standardization and proceduralization of changes of Party committee members and state leaders. One of the important hallmarks is retirement at a prescribed age, not half-retirement or transfer of posts. This has been thoroughly institutionalized. Another important hallmark is that the members of the Political Bureau of the CPC Central Committee and members of the CPC Central Committee secretariat are younger, reaching the average age formerly obtaining at the Thirteenth Party Congress. The issue used to be very sensitive and it used to be very risky to raise the issue before the Sixteenth Party Congress. Courage is needed to put forward bold views. But it was for the sake of the fundamental interests of the Party and state that I stated my views. This book collects the article "The Sixteenth Party Congress and Replacement of Old Officials with the New," which gives an objective assessment of how the Party realized the goal. It has in fact gone beyond my expectations. I am not sure that our recommendations have played a positive role, but the fact that I dared to speak out shows that the policy decision-making process in China has undergone encouraging changes.

If we say that A-bombs are material, good policies and public policies are spiritual A-bombs (a famous metaphor of Mao Zedong). The key lies in how to turn spiritual A-bombs into material A-bombs. Only when a scholar provides knowledge that becomes public knowledge is it possible to have a social impact. Only when research achievements have become public policies with positive application, is it possible to influence social changes and push society forward. It is not enough to have personal knowledge on major social and economic issues. One must take the initiative to influence policy decision-makers so that knowledge becomes the common understanding of not only policy-makers but also the whole society. Only by doing this is it possible to benefit the people 


\section{Economic and social transformation in China}

and promote social progress. I call this process knowledge innovation, spread and contribution. Despite the fact that I teach at the Chinese Academy of Sciences of Tsinghua University, I advocate the necessity of coming down from the top of the pyramid and going into society. In order to become an outstanding scholar, it is essential to lead the social tide with knowledge, to effectuate changes in social concepts and to push social development, as history and historical assessment have shown.

At the same time, a more democratic society means everyone may have the opportunity to offer his or her good ideas. This is determined by whether or not you can obtain the latest knowledge in the world, whether or not you know, assimilate and accumulate the best knowledge so far known to man and whether or not you can localize this knowledge. This is the opportunity and challenge brought about by reform and opening up.

Unlike the experience of the older generation of scholars such as Ma Yinchu, our generation has had the opportunity to get involved in this reform and development era on a scale never witnessed in human history and we may contribute to society with our acquisition, innovation, spread and exchange of knowledge. Research into national conditions is so tempting that I will never be able to stop studying, thinking, researching and writing. 


\section{Notes}

\section{Introduction}

1 Z. Mao, "Rende zhengque sixiang shi cong naili laide?" (Where do Correct Ideas Come From?), in Selected Readings from the Works of Mao Zedong, Beijing: Waiwen Chubanshe (Foreign Language Press), 1967, p. 405.

2 Z. Jiang, "Quanmian jianshe xiaokang shehui, kaichuang zhongguo tese shehui zhuyi shiye xin jumian" (Report at the Sixteenth National Congress of the People's Republic of China), Shiliuda yilai zhongyao wenxian xuanbian (Selective Collection of Important Documents since the Sixteenth National Congress of the Communist Party of China), Beijing: Zhongyang wenxian chubanshe (Central Documentation Press), 2004.

\section{Why has China's economy grown so fast?}

1 This article was based on a presentation made by Dr. Angang $\mathrm{Hu}$ at the Institute of the Far Eastern Studies of Russia Academy of Sciences on June 18th, 2004 when he was awarded Honorary Doctor in Economics.

2 A. Gerschenkron, Economic Backwardness in Historical Perspective, Cambridge, MA: Harvard University Press, 1962.

3 A. Maddison, Monitoring the World Economy, 1820-1992, Paris: OECD, 1995.

4 V. Tomas and Y. Wang, "East Asian Lessons from Economic Reforms," in W. Woo, S. Parker and J. Sachs, Economies in Transition: Comparing Asia and Eastern Europe, Cambridge: The MIT Press, 1990, pp. 217-242.

5 Gerschenkron, Economic Backwardness.

6 Investigation and study of 48 product innovations in chemical, pharmaceutical, electronics and machinery industries show the imitation cost is $65 \%$ of the innovation cost on average. But different products vary greatly. About half of the products' imitation and innovation costs are $60 \%-90 \%$. See Y. Shu, Z. Xie and A. Kong, Models of Modern Economic Growth (Xiandai jingji zengzhang moxing), Shanghai: Fudan University Press (Fudan daxue chubanshe), 1998.

7 A. Maddison, The World Economy: A Millennial Perspective, Paris: OECD, 2001.

8 A. Hu, "Future Economic Growth of China Is Determined by TFP" (zhongguo weilai de jingji zengzhang qujue yu TFP), in A. Hu (ed.) China's Grand Strategy (zhongguo da zhanlue), Hangzhou: Zhejiang People's Press (Zhejiang renmin chubanshe), 2003, pp. 241-251.

9 World Bank, China 2020 - Development Challenges in the New Century, Washington, DC: the World Bank, 1997.

10 A. Maddison, Chinese Economic Performance in the Long Run, Paris: OECD Development Centre, 1998. 


\section{Notes}

11 World Bank, The East Asian Miracle: Economic Growth and Public Policy, New York: Oxford University Press, 1993.

12 National Bureau of Statistics of China (guojia tongjiju), China Statistical Abstract 2004 (zhongguo tongji zhaiyao 2004), Beijing: China Statistics Press (zhongguo tongji chubanshe), pp. 17, 158. The figure might be overestimated, because China's GDP might have been underestimated according to the official exchange rate of RMB to the dollar. This means that the ratio of China's trade to GDP is likely to be overestimated. See World Bank, China 2020, p. 95.

13 World Bank, China 2020, p. 95.

14 Q. Wu, "Impact of Institutional Changes on Long-Term Economic Performance: Theories, Models and Application," doctoral dissertation at School of Economics and Management of Tsinghua University under the supervision of Dr. Hu Angang, 2002.

15 The ten indicators are divided into three categories: one is technical knowledge: papers on science and technology (per million people), patent applications by residents (per million people), net inflow of FDI in GDP (\%); one is intelligent capital: per capita years of education (years), enrolment in primary schools (\%), enrolment in secondary schools (\%), enrolment in tertiary education (\%); the other is materialized knowledge: TV penetration rate (\%),telephone penetration rate (including both mobile and fixed (\%), Internet using rate (\%). See Y. Xiong, "Yi zhishi wei jichu de fazhan zhanlue yanjiu: lilun moxing yu jingyan fenxi" (Study on Knowledgebased Development Strategy: Economic Model and Empirical Analysis), Management master's degree paper of Tsinghua University (Supervisor: Angang Hu), School of Public Policy and Management of Tsinghua University, October 2003.

16 A. Hu, "Dangqian woguo jingji yu shehui fazhan xingshi fenxi he ruogan jianyi" (Analysis of the Current Economic and Social Development and Recommendations), in A. Hu (ed.) Yingxiang juece de guoqing baogao (Reports that Influenced Policy Decision-making in China), Beijing: Tsinghua University Press (qinghua daxue chubanshe), 2002, pp. 68-72.

17 World Bank, World Development Report 2000/2001: Attacking Poverty, Chinese Edition, Beijing: Zhongguo caizheng jingji chubanshe (China Financial and Economic Publishing House), 2001.

18 Y. Xiong, Yi zhishi wei jichu de fazhan zhanlue yanjiu.

19 World Bank, World Development Indicators, Washington, DC: World Bank, 2001, Table 2.2.

20 Wen Jiabao, "Laogu shuli he renzhen luoshi kexue fazhanguan" (Foster a New Approach to Development), cited from Renmin ribao (People's Daily), February 29, 2004.

21 Renmin ribao (People's Daily), June 18, 2003.

$22 \mathrm{Hu}$, Yingxiang juece de guaging baogao.

\section{Comprehensive national power (1980-2000)}

1 The Chinese version of this chapter was published on Zhanlue yu guanli (Strategy and Management), 2002, No. 3. The article was coauthored with Dr. Honghua Men and presented at Carnegie International Peace Foundation in February 2004. The authors thank Mr. Shaujie Zhou for his help in data calculation and related analysis.

2 Zhongguo xiandai guoji guanxi yanjiu suo (China Institute of Contemporary International Relations), Quanqiu zhanlue da geju: xin shiji zhongguo de guoji huanjing (Global Strategic Pattern - International Environment of China in the New Century), Beijing: Shishi Press, 2000.

3 S. Huang, Zonghe guoli xinlun: jianlun xin zhongguo zonghe guoli (New Theory on CNP: CNP of China), Beijing: Zhongguo shehui kexue chubanshe (Chinese Academy of Social Sciences Press), 1999. 
4 A. Tellis et al., Measuring National Powers in the Postindustrial Age, Santa Monica: RAND, 2000.

5 Ibid.

6 M. Porter, The Competitive Advantage of Nations, New York: The Free Press, 1990; M. Porter et al., The Global Competitiveness Report 2000, New York: Oxford University Press, 2000.

7 R. J. Barro and J. Lee, International Data on Educational Attainment Updates and Implication, NBER Working Papers, 2000.

8 The last indicator is drawn from the global education databank of Barro and Lee of Harvard University. Data for China come from the national population census (National Bureau of Statistics, 1982, 1990, 2000).

9 Porter, The Competitive Advantage of Nations.

10 Tellis et al., Measuring National Powers.

11 K. Knorr, The War Potential of Nations, Princeton: Princeton University Press, 1956.

12 S. Wang (ed.), Shijie zhuyao guojia zonghe guoli bijiao yanjiu (Comparative Studies of the Comprehensive National Power of the World's Major Nations), Changsha: Hunan chubanshe (Hunan Press), 1996.

13 Huang, Zonghe guoli xinlun.

14 Huang, Zonghe guoli xinlun, p. 119; Wang, Zhuyao guojia zonghe guoli bijiao, p. 439; Zhongguo xiandai guoji guanxi xueYuan, Global Strategic Pattern, p. 28.

15 P. Kennedy, "The Eagle Has Landed: The New U.S. Global Military Position," Financial Times Weekend, February 1, 2002.

16 Guojia tongjiju (National Bureau of Statistics of China), China Statistical Abstract (2001), Beijing: Zhongguo tongji chubanshe (China Statistics Press), 2002, p. 19.

17 Porter, The Global Competitiveness Report 2000.

18 A. Maddison, Chinese Economic Performance in the Long Run, Paris: OECD, 1998.

19 A. Maddison, The World Economy: A Millennial Perspective, Paris: OECD, 2001, Table 13.

20 Porter, The Global Competitiveness Report 2000.

21 Maddison, Chinese Economic Performance.

$22 @ *$ NOTES:Kennedy, “The Eagle Has Landed”.

23 National Statistics Bureau, China Statistical Abstract 2001, Beijing: China Statistics Press, 2001, p. 168.

24 World Bank, World Development Indicators 2001, Washington DC: World Bank, 2001, pp. 12-14, 310-312.

25 Alexei Arbatov, "US Military and Industry Integrity," Russian News Service, February 5, 2002.

26 A. Hu, "Prospects for 21st Century: How Should China Catch up with the United States," China Studies Report, 2000, Issue No. 80.

\section{Why has China's TFP dropped in 1995-2001?}

1 This article is coauthored with Dr. Jinghai Zheng and was originally published in Zhongguo jingji shibao (China Economics Times), March 26, 2004.

2 J. Sachs and W. Woo, "Understanding China's Economic Performance," NBER Working Paper Series, 1997, Working Paper 5935; Z. Hu and M. Khan, "Why is China Growing So Fast?" Economic Issues, 8, 1997, Washington, DC: International Monetary Fund; A. Young, "The Razor's Edge: Distortions and Incremental Reform in the People's Republic of China," Quarterly Journal of Economics, 2000, Vol. CXV, Issue 4; D. Bhattasali, "Sustaining China's Development: Some Issues," Presentation to Tsinghua University 90th Anniversary Celebrations Seminar Series, Beijing, People's Republic of China, April 24, 2001; Y. Wang and Y. Yao, "Sources of China's 
Economic Growth 1952-1999: Incorporating Human Capital Accumulation," China Economic Review, 2003, 14, pp. 32-52; A. Hu, "Weilai zhongguo jingji zengzhang qujueyu TFP" (China's Future Economic Growth Depends on TFP), in A. Hu (ed.), Zhongguo Dazhanlue (Grand Strategy of China), Hangzhou: Zhejiang renmin chubanshe (Zhejiang People's Press), 2003, pp. 241-251.

3 According to the World Bank estimate, China's average TFP growth was $4.3 \%$ in 1978-1995, contributing to 46\% of economic growth. See World Bank, China 2020: Development Challenges in the New Century, Washington DC: World Bank, 1997.

4 According to the calculation by A. Maddison, China's TFP annual growth was $-0.78 \%$ from 1952 to 1978 and $2.23 \%$ from 1978 to 1995 , contributing to $30 \%$ of economic growth. See A. Maddison, Chinese Economic Performance in the Long Run, Paris: OECD, 1998.

5 The authors of the chapter have found that the first half of the 1990s experienced a rapid "capital deepening" process in its economic growth and the ability to absorb new labor was weakened. The state industrial enterprises followed a "capital deepening" technical line in industrialization, with capital investment growth far higher than employment growth and capital intensity rising rapidly. The net value of fixed assets of industrial enterprises that practiced independent accounting increased by 2.4 times in 1990-1996, but the number of employment grew only $1.1 \%$. See A. $\mathrm{Hu}$, Jiuye yu fazhan (Employment and Development), Shenyang: Liaoning renmin chubanshe (Liaoning People's Press), 1998; J. Zhang, "Gaige yilai zhongguo de ziben xingcheng yu jingji zengzhang: yixie faxian jiqi jieshi” (Capital Formation and Economic Growth of China since Reform: Some Discoveries and Interpretations), available at http://prozhang.nease.net/lunwen/capital\%20formation.pdf (accessed June 20, 2004).

6 J. Zheng and A. Hu, "Zhongguo gaige shiqi shengji shengchanlu zengzhang bianhua de shizheng fenxi (1979-2001)" (Provincial Productivity Trend in China (1979-2001): Analysis and Policy Implications), Center for China Studies Working Paper, Beijing: Tsinghua University, 2004, Issue No. 1.

7 World Bank, The Quality of Growth, Chinese edition, Beijing: Zhongguo caijing chubanshe (China Finance and Economics Press), 2001.

8 Ibid.

9 Ibid.

10 J. Knight and L. Song, "Economic Growth, Economic Reform and Rising Inequality in China," in Riskin, Zhao and Li (ed.), China's Retreat from Inequality: Income Distribution and Economic Transition, New York; M.E. Sharpe, 2001, pp. 84-122.

11 B. Lin, "Zhongguo de jingji zengzhang, pinkun jianshao yu zhengce xuanze" (China's Economic Growth, Poverty Reduction and Policy Options, Jingji yanjiu (Economic Research Journal), 2003, Issue 12, pp. 15-25.

12 M. Ravallion and S. Chen, Measuring Pro-Poor Growth, WPS 2666. Available at http://econ.worldbank.org/files/15290-wps2666.pdf (accessed June 20, 2004).

13 P. Xie and L. Lu, "Zhongguo jinrong fubai yanjiu: cong dingxing dao dingliang" (China Financial Corruption Study: From Qualitative Analysis to Quantitative Analysis), Bijiao (Comparative Studies), 2003, Issue No. 8, pp. 1-48.

$14 \mathrm{~A}$. $\mathrm{Hu}$, "Zhongguo jiushi niandai houbanqi fubai zaocheng de jingji sunshi" (Economic Costs Caused by Corruption in the Latter Half of the 1990s), Guoji jingji pinglun (International Economic Review), 2001, vol. 33, pp. 12-21.

15 Guojia tongjiju (National Bureau of Statistics of China), China Statistical Yearbook (2003), 2003, pp. 146-147.

16 A. Hu, "Jingji zengzhang zhanlue: weilai zhongguo jingji zengzhang qujueyu TFP" (China's Future Economic Growth Depends on TFP), in A. Hu (ed.), Zhongguo da zhanlue, Hangzhou: Zhejiang renmin chubanshe (Zhejing People's Press), 2003, pp. 241-251. 


\section{From unevenness to coordination for China's regional development} (1978-2004)

1 Presentation for China Reform Forum: Rand Corporation Annual Meeting, June 2005. Li Chunbo helped with the editing.

2 A. Hu (ed.), Quyu yu fazhan: xibu kaifa xinzhanlue (Regions VS Development: New Strategy of Development of China's West), Beijing: Zhongguo jihua chubanshe (China Planning Press), 2001.

3 A. Hu, S. Wang and X. Kang, Zhongguo diqu chaju baogao (Reports on Regional Disparities in China), Shenyang: Liaoning renmin chubanshe (Liaoning People's Press), 1995.

4 Such as A. Hu et al., Zhongguo diqu chaju baogao; K. Tsui, "Economic Reform and Inter-provincial Inequalities in China," Journal of Development Economics, 1996, vol. 50, issue 2, pp. 353-368; Y. Lin, F. Cai and Z. Li, "Zhongguo jingji zhuanxing de diqu chayi fenxi" (Analysis of Gaps among Different Regions during the Period of Economic Transformation in China), Jingji Yanjiu (Economic Research Journal), 1998, vol. 6, pp. 3-10; X. Wang, and G. Fan, "Zhongguo diqu chaju de biandong qushi he yingxiang yinsu" (Trend of Variations in Terms of Gaps among Different Regions of China and Factors Influencing Such Variations), Jingji Yanjiu (Economic Research Journal), 2004, vol. 1.

5 S. Wang and A. Hu, The Political Economy of Uneven Development: The Case of China, New York: M. E. Sharpe, 1999; A. Hu and P. Zou, Shehui yu fazhan: woguo shehui fazhan diqu chaju de yanjiu (Society and Development: Study of Gaps of Social Development among Different Regions of China), Hangzhou: Zhejiang renmin chubanshe (Zhejiang People's Press), 2000; A. Hu (ed.), Quyu yu fazhan: xibu kaifa xinzhanlue (Regions VS Development: New Strategy of Development of China's West), Beijing: Zhongguo jihua chubanshe (China Planning Press), 2001.

6 Wang and Hu, The Political Economy of Uneven Development; Hu and Zou, Shehui yu fazhan; Hu (ed.), Quyu yu fazha; A. Hu and Y. Xiong, "Woguo zhishi fazhan diqu chaju yanjiu: tedian, duice he chengyin" (Analysis of Regional Disparities of China's Knowledge Development: Characteristics, Causes and Countermeasures), Guanli Shijie (Management World), 2000, Issue 3; UNDP, China Human Development Report 2002 (Chinese edition), Beijing: Zhongguo caizheng jingji chubanshe (China Finance and Economics Publishing House), 2002.

7 UNDP, China Human Development Report 2002.

8 See World Bank, World Development Report 1998/99: Knowledge for Development, New York: Oxford University Press, 1999; World Bank, China and the Knowledge Economy, Seizing the 21st Century, Washington, DC: World Bank Institute, 2001.

9 World Bank, China: Promoting Growth with Equity, (Chinese edition), Tsinghua University Publishing House, 2004.

10 Renmin ribao (People's Daily), October 15, 2003.

11 See B. Naughton, "How Much Can Regional Integration Do to Unify China's Markets?" Paper for Conference on Policy Reform in China, Center for Research on Economic Development and Policy Research, Stanford University, November 18-20, 1999; OECD (Organization for Economic Cooperation and Development), China in the World Economy (Chinese version), Tsinghua University Publishing House, 2004; World Bank, China: Promoting Growth with Equity.

\section{China's economic growth and poverty reduction (1978-2002)}

1 This chapter is coauthored with Linlin $\mathrm{Hu}$ and Zhixiao Chang. It was originally presented at "A Tale of Two Giants: India's and China's Experience with Reform and Growth," International Monetary Fund and National Council of Applied Economic Research of India, New Delhi, India, November 14-16, 2003. 
2 A. Sen, "The Conceptual Challenge of Evaluating Inequality and Poverty," Economics (quarterly), Beijing: China Center for Economic Research, Peking University, 2003, vol. 2, issue 2, pp. 257-258.

3 A. Sen, "Preface", Development as Freedom (Chinese version), Beijing: Renmin daxue chubanshe (Chinese People's University Press), 2002.

4 A. Khan, Poverty in China in the Period of Globalization: New Evidence on Trend and Pattern (Issues in Development Discussion Paper), Development Policies Dept., International Labor Office, 1998.

5 Khan, Poverty in China in the Period of Globalization.

6 The human poverty index is a new index adapted by UNDP in 1997 to measure degrees of poverty. This index measures three main elements in human life, such as life expectancy, lack of knowledge and decent life. Among them, life expectancy is reflected by the proportion of people who do not live longer than 40 years in the total population; lack of knowledge is measured by rate of illiterate adults; life standard is comprehensively tested by three variables, namely the proportion of people without access to safe water, proportion of people without access to medical care and proportion of underweight children (below 5 years old).

7 P. Zhang, "Zhongguo zhuanxing shiqi de shouru fenpei" (Income Distribution in China during Transition), Economic Research, vol. 4, 1998.

8 Guojia tongjiju (National Bureau of Statistics of China), Zhongguo nongcun pinkun jiance baogao 2001 (A Monitoring Report on China's Rural Poverty 2001), 2001.

9 I. Adelman and D. Sunding, "Economic Policy and Income Distribution in China," Journal of Comparative Economics, September, 1987.

10 Quoted in E. Ahmad and Y. Wang, "Inequality and Poverty in China: Institutional Change and Public Policy, 1978 to 1988," World Bank Economic Review, 1991, vol. 5 (2).

11 Ahmad and Wang, "Inequality and Poverty in China," pp. 231-257.

\section{China's macro-economy and health}

1 This chapter was originally presented at the international symposium on Global Macro Economy and Health co-sponsored by the State Commission of Planning and Development, Ministry of Finance, Ministry of Health and WHO on December 18, 2002. This is a response to the report by Jeffery Sachs on global macro economy and health.

2 "Two systems" does not refer to the "one country, two systems" carried out between the mainland and Hong Kong, and Macao as well, but to the two different systems of identity, education, employment, public service and financial transfer for the inhabitants urban areas and rural areas. "Four worlds" refers to China's unbalanced development in different regions. For more details, please refer to A. Hu (ed.), "Forward," The Strategy of China, Hangzhou: Zhejing renmin chubanshe (Zhejiang People's Press), 2002.

3 A. Maddison, Monitoring the World Economy: 1820-1992, Paris: OECD, 1998.

4 Maddison, Monitoring the World Economy.

$5 \mathrm{Hu}$, "Forward," The Strategy of China.

6 RAND, China's Continued Economic Progress: Possible Adversities and Obstacles, 5th Annual CRF-RAND Conference, Beijing, October 31-November 1, 2002.

7 Y. Huang, The Health Condition of China, Shanghai: Shanghai Medical University Press, 1994, pp. 35.

8 The World Bank published its national savings data using a green national accounts system in 2002. See World Bank, World Development Indicators 2002, Washington, DC: World Bank, 2002, pp. 188-191.

9 The report mentions the low-cost measures aimed at chronic and non-contagious diseases, for example, aimed at cardiovascular system diseases, diabetes and cancer; 
some prevent actions related to drinking and eating, smoking and lifestyle are taken as intervening measures. It also mentions the low-cost cast management of diabetes and heart disease, etc. Also, to strengthen the intervention provided for contagious diseases and reproduction health will simultaneously enhance the health care level for non-contagious diseases.

10 This percentage in America is $13 \%$; in general Western countries it is $8-9 \%$; in Japan it is a bit lower, 7-8\%. All are higher than in China.

11 The Commission on Macroeconomics and Health (CMH) of the World Health Organization (WHO), Investing in Health for Economic Development, p. 45.

12 The concept of "governance" first appeared in the report of the World Bank in 1989. It has gradually developed into a theory of rich intentions and wide applications in the ten years following and has been widely applied in many countries in politics, administration and reform of social management. For more details, please refer to $\mathrm{K}$. Yu (ed.), Governing and Good Governance, Beijing: Shehui kexue wenxian chubanshe (Social Science Documents Press), 2000.

\section{Health insecurity}

1 This chapter is coauthored with Linlin Hu. It was originally comments on the speech by Rao Kewin, director of the Statistics and Information Center of the Ministry of Public Health entitled "Major Results of the Third National Health Survey" at the Forum of China's Health Service Survey called jointly by the Ministry of Public Health, WHO and DELI on December 2, 2004. The comments have been revised. The majority of the data in the article come from Statistics and Information Center of the Ministry of Health, Disanci guojia weisheng fuwu diaocha fenxi baogao (Analytical Report on the Third National Health Service Survey), Beijing: Zhongguo xiehe yide daxue chubanshe (Peking Union Medical College Press), 2004.

2 Ministry of Health, Disanci weisheng diaocha baogao.

3 A. Hu (ed.), Toushi SARS: Jiankang yu fazhan (SARS in Perspective: Health and Development), Beijing: Qinghua daxue chubanshe (Tsinghua University Press), 2003, p. 20.

4 The health conditions in the Third National Health Service Survey cover three aspects: first, the general evaluation of the physical conditions of people surveyed, which requires people surveyed to answer "very good," "good," "just so so," "poor" and "very poor" on their body and mental state; second, the self evaluation of the bodily conditions, including self service, work and house chore abilities, vision, bodily pain, requiring the respondents to give one of the four answers "difficult" to "without difficulty." Third, the self evaluation of the mental state, including energy concentration or memory, in poor spirit due to not good rest, and sad, worry, low spirit or depressed.

5 National Bureau of Statistics of China, 2004 Zhongguo tongji zhaiyao (China Statistics Abstract 2004), Beijing: Zhongguo tongji chubanshe (China Statistics Press), 2004, pp. 22 and 99.

6 Xinhuanet.com, February 21, 2004.

7 The diseased group defined by the survey report are from the angle of medical and health services and should be regarded as self reported cases. They are, specifically: (1), feeling uncomfortable but refusing to go to hospital for treatment; (2) feeling unfit but refusing to go to hospital for treatment and take medicines or receive some auxiliary treatment by themselves; (3) feeling unfit but refusing either to go to hospital or take medicine or receive auxiliary treatment, absent from work or school for at least one day. One of the three cases is regarded as being sick.

8 The definition of chronic diseases covered by the survey is: all kinds of chronic diseases diagnosed by doctors within six month before the survey through inquiries, including chronic communicable diseases (such as TB) and chronic noncommunicable diseases (such as heart trouble and high blood pressure) or such cases 
occurring six months before and recurring within six months before the survey and treatment measures were adopted such as taking medicine and physiotherapy.

9 Calculation based on World Bank, World Development Report 2002: Building Institutions for Markets, New York: Oxford University Press, 2002.

10 National Bureau of Statistics of China, Zhongguo tongji nianjian 2004 (China Statistical Yearbook), Beijing: Zhongguo tongji chubanshe (China Statistics Press), 2004, p. 560.

11 Regular drinking in the survey refers to drinking at least three times a week and 156 times a year.

12 Calculated based on data on p. 95 and p. 389 of China Statistical Yearbook 2004.

13 Xinhua News Agency, Chengdu, November 28, 2004.

14 J. Gescher, "China's QBL: Some Snapshots," POSCO research institute (POSRI) International Forum on China's Development: Sustainable China, Seoul, November 2004.

15 Documentation Research Office of the Central Committee of the Communist Party of China (CPC), Shisanda yilai zhongyao wenxian xuanbian (Selection of Important Documents since the 13th Central Committee of the Communist Part of China), Volume B, People's Publishing House, 1991, pp. 1401 and 1404.

16 Ministry of Health, April 1, 2001, website of the Ministry.

17 Documentation Research Office of the Central Committee of the Communist Party of China (CPC), Shisida yilai zhongyao wenxian xuanbian (Selection of Important Documents since the 14th Central Committee of the Communist Party of China), Beijing: Renmin chubanshe (People's Publishing House), 1997, Volume B, p. 1502.

18 Ministry of Health, April 1, 2001, website of the Ministry.

19 Other objectives set by the Tenth Five-Year Plan include: introduce in an all-round manner a basic medical insurance system for urban workers according to the model of social pool plus individual accounts to ensure the basic medical needs; introduce reform of the medical insurance system, medical organizations and drug production and distribution systems, build a medical cost sharing system, competition mechanism among medical organizations and market operational mechanism for the distribution of medicine; set up a social medical rescue system; encourage employer units with the conditions to set up an annuity and supplementary medical insurance for their workers; develop community health services. "Outlined Tenth Five-Year Plan for National Economic and Social Development," approved at the first session of the Ninth National People's Congress on March 15, 2001. See Development Planning Department of the National Development and Reform Commission, Guojia "shiwu" zhongdian zhuanxiang guihua (Special Program for Key Projects of the Tenth Five-year Plan Period), Beijing: Zhongguo jiage chubanshe (China Pricing Publishing House), 2002, pp. 338-339, 370-371.

20 Medical insurance is aimed at the life or health of the people. When people are in need of treatment, the state or social or commercial organizations should provide necessary medical service or economic compensation. It is, in essence, a social risk sharing program, which, through social regulation, ensures the access to basic medical services when the individual's health is at stake so that it would not affect normal life and work due to medical services. Medical insurance includes social medical insurance and commercial medical insurance. Due to the special nature of diseases and medical and health services, many countries in the world have incorporated medical insurance into social insurance. It is part of social insurance. Only a small part is operated by commercial insurance as a supplement to medical insurance. Medical insurance is the important factor in human development and also one of the major areas where government should display its functions. See H. Liu and S. Zhao, "Study of the Policy of the Chinese Government Intervention in Medical Insurance," Zhongguo ruankexue (China Soft Science), Beijing: Zhongguo ruankexue zazhishe (China Soft Science Magazine), 2004, Issue No. 11, p. 15. 
21 Documentation Research Office of the Central Committee of the Communist Party of China (CPC), Shisida yilai zhongyao wenxian xuanbian, p. 1504.

22 Ministry of Labor and Social Security and Documentation Research Office of CPC Central Committee, Xinshiqi laodong he shehui baozhang zhongyao wenxian xuanbian (Selection of Major Documents on Labor and Social Security in the New Period), Beijing: Zhongguo laodong he shehui baozhang chubanshe (China Labor and Social Security Publishing House), 2002, pp. 346-352.

23 A. Hu (ed.), Zhongguo tiaozhan quanqiuhua (Globalization Challenges China), Beijing: Peking University Press, 2002, pp. 107-111.

\section{Developing human resources to cope with an aging society}

1 This chapter was coauthored with L. Hu, Ph. D. candidate at the School of Public Policy \& Management, Tsinghua University, and Y. Xiong, Post Doctor at the School of Public Policy \& Management, Tsinghua University.

2 When China began to enter an aging society, her per capita GDP was only 850 US dollars if calculated according to the exchange rate in 2000 .

3 Guojia tongjiju (National Bureau of Statistics of China), Zhongguo tongji zhaiyao 2005 (China Statistical Abstract 2005), Beijing: Guojia tongji chubanshe (China Statistical Press), 2005, p. 39.

4 Data are quoted from Guojia tongjiju (National Bureau of Statistics), Zhongguo tongji nianjian 2004 (China Statistical Yearbook 2004), Beijing: Zhongguo tongji chubanshe (China Statistics Press), 2004.

5 Actually many employees retire right before the formal retirement age. That is because many enterprises permit or force their employees to retire early in order to be more efficient. So China's actual retirement age is lower than the official line.

6 F. Cai and X. Meng, "Renkou zhuanbian, tizhi zhuangui yu yanglao baozhang moshi de ke chixuxing" (Demographic Transition, Institutional Transition and the Sustainability of Old Age Security System), Comparitive Studies, 2004, vol. 1.

$7 \mathrm{H}$. Lv and H. Kang, "Zhongguo de renkou laolinghua yu kechixu fazhan" (China's Aging and Sustainable Development), Zhongguo ruankexue zazhi (Chinese Soft Science Magazine), 2000, vol. 7.

8 P. Cipollone, "Education and Income," International Encyclopedia of Economics of Education, Oxford: Pergamon Press, 1995.

9 The average schooling years of people aged above 15 is 7.85 years and that of people above 25 is 7.42 years in 2000 . The two items combined is still not at the second grade level of junior secondary school, similar to the level of the United States 100 years ago or nearly 4 years lower than the Republic of Korea.

10 According to state regulations, during the time when laid-off workers from stateowned enterprises enter the re-employment service centers, the re-employment service centers would pay the basic old age insurance fee for them. For those who have retained their labor relations with their original units, the basic old age insurance fees would be paid by the workers themselves and their original units or by workers themselves to the old insurance agents on a monthly basis.

\section{China's urban unemployment and social security (1993-2000)}

1 This chapter was originally submitted to the conference on China's Integration with the World Economy sponsored by the Korean Institute of International Studies and Center for Chinese Economy at Peking University, Beijing, China, August 25-26, 2001. The author received assistance from Yang Yuxin in writing this paper.

2 Guojia tongjiju (National Bureau of Statistics of China), Zhongguo tongji nianjian 2000 (China's Statistical Yearbook), Beijing: Zhongguo tongji chubanshe (China Statistics Press), 2000, p. 115. 


\section{Notes}

3 The new definition of the employment population refers to those who are now paid by the working unit and those who are still paid by the working unit but don't work temporarily due to training or diseases.

4 Guojia tongjiju, Zhongguo tongji nianjian 2000, pp. 126 and 128; Guojia tongjiju (National Bureau of Statistics of China), Zhongguo tongji zhaiyao 2000 (China Statistical Abstract), Beijing: Zhongguo tongji chubanshe (China Statistics Press), 2000, p. 46.

5 World Bank, World Development Indicators 2002, Washington DC: World Bank, 2002, p. 63.

6 Guojia tongiju (National Bureau of Statistics of China), Zhongguo laodong tongji nianjian 2000 (China Labor Statistical Yearbook 2000), 2000, p. 623.

7 The data come from various years of Zhongguo laodong tongji nianjian (China Labor Statistical Yearbook), 1998, p. 74; 1999, p. 63; 2000, p. 64.

8 UNDP, Human Development Report 1999, p. 215.

9 There is a large number of surplus labor force in China's rural area, thus its ratio of hidden unemployment is very high. However, the unemployment rate is very difficult to estimate. To simplify, I propose to replace nationwide comprehensive unemployment by constructed real urban unemployment. As a conservative estimate, the hidden unemployment rate in rural area might be higher than the real urban unemployment rate. Since the ratio of the primary industry in GDP is lower than 20 percent, minor error in the estimate of the rural unemployment rate has little effect on the precision of the estimate of overall economic costs. Thus, I believe that the hypothesis can be accepted.

10 Guojia tongjiju, Zhongguo tongji nianjian 2000, pp. 750-751.

11 A. Hu, Jiuye yu fazhan (Employment and Development), Shenyang: Liaoning renmin chubanshe (People's Publishing House of Liaoning), 1998.

12 The figure is 50-60 percent. Please refer to International Labor Organization, World Employment Report: 1998-1999: Employability in the Global Economy - How Training Matters, Geneva: International Labor Organization, 1999.

13 According to World Employment Report 1998-1999, the ratio of informal sectors in employment in most developed countries is higher than 30 percent, the ratio in such countries as Spain, the Netherlands, Denmark and Japan is over 40 percent.

14 Guojia tongjiju (National Bureau of Statistics of China), Zhongguo laodong tongji nianjian 1997 (China's Labor Statistical Yearbook 1997), 1997, pp. 4, 9. Guojia tongiju (National Bureau of Statistics of China), Zhongguo tongji zhaiyao 2005 (China Statistical Abstract), 2005, pp. 40, 45.

\section{Genuine national savings and natural capital cost in China} (1970-2001)

1 This chapter was written in January 2001. Recommended by Premier Zhu Rongji, the article was published in the Xinxi Cankao (Information Reference) of the State Council. The article was publicly published in Beijing daxue xuebao (Journal of Beijing University, Philosophy and Social Science), No. 4, 2001. This article introduced to the Chinese leaders a new concept of green GDP accounting and the evaluation of the natural capital cost and relevant policies in the past two decades for the very first time.

2 World Bank, World Development Report 2000/2001: Attacking Poverty, New York: Oxford University Press, 2000.

3 World Bank, World Development Indicator Database 2000.

4 A. Kunte, K. Hamilton, J. Dixon and M. Clemens, Estimating National Wealth: Methodology and Results, Environment Department Papers, The World Bank, January 1998; K. Hamilton and M. Clemens, Genuine Savings Rates in Developing Countries, Environment Department, The World Bank, August 1998. 
5 World Bank, Expanding the Measure of Wealth: Indicators of Environmentally Sustainable Development (Chinese edition), Beijing: Zhongguo huanjing kexue chubanshe (China Environment Science Press, 1998.

6 World Bank, Expanding the Measure of Wealth.

7 S. Fankhauser, Valuing Climate Change: The Economics of the Greenhouse, London: Earthscan, 1995.

8 J. Sachs and A. Warner, Natural Resource Abundance and Economic Growth, Development Discussion Paper No. 517a, Harvard Institute for International Development, Harvard University, 1995.

9 World Bank, World Development Indicator Database 2000.

10 World Bank, China 2020: Development Challenges in the New Century, Washington, DC: World Bank, 1998.

11 World Bank, Expanding the Measure of Wealth (Chinese edition).

12 World Data 2000/2001, Kokuseisha, 2000.

13 World Data 2000/2001, Kokuseisha, 2000.

\section{Corruption: an enormous black hole}

1 This chapter was written on February 3, 2002 and published on Guoqing baogao (Reports of China Studies), No. 20, February 8, 2002.

$2 \mathrm{~A}$. $\mathrm{Hu}$, "Zhongguo jiushi niandai houbanqi fubai zaocheng de jingji sunshi" (Economic Cost Caused by Corruption in the late 1990s in China), Guoji jingji pinglun (Review of International Economy), 2001, vol. 33, pp. 12-21.

3 H. Gu, "Scientific Estimation of Economic Cost from Corruption - A Discussion with Professor Hu Angang," Renmin ribao neican (Internal Consultancy of People's Daily), November 23, 2001, Issue 45, pp. 19-25.

4 Xiao Yang, "The Work Report of the Supreme Court of the People's Republic of China at the third session of the ninth National People's Congress ", March 10, 2000.

5 Xinhua News Agency, Beijing, January 15, 1999.

6 Import volume increased 209.26 billion RMB over 1999, and the increase of customs tax was equivalent to one-third of import increase. Zhu Rongji, September 3, 2000.

7 Renmin ribao (People's Daily), July 26, 2001.

8 Xinhua News Agency, Beijing, July 29, 2000.

9 Jingji xinxi bao (Economic Information Daily), January 17, 2002.

10 Zhongguo jijian jiancha bao (China Disciplinary Inspection), January 4, 2002.

11 Zhongguo jijian jiancha bao, January 10, 2002.

12 Zhongguo jingji shibao (China Economic Times), August 4, 2001.

13 Report of Wei Jianxing on the third session of Committee of Disciplinary Inspection of China, Economics Daily, January 8, 1999.

14 Zhongguo jingji shibao, August 4, 2001.

15 Xinhua News Agency, Beijing, January 15, 2002.

16 People's Daily, January 28, 2002.

17 Zhongguo jingji shibao, August 4, 2001.

18 Zhongguo jingji shibao, August 4, 2001.

19 Renmin ribao, January 22, 2002.

20 Zhongguo jingji shibao, August 4, 2001.

21 Jingji ribao (Economic Daily), July 24, 2001.

22 People's Bank of China, 2001.

23 China Disciplinary Inspection, January 28, 2002.

24 Lightening Financial Burden Township Enterprises Office, State Council, August 21, 2001.

25 Zhongguo jijian jiancha bao, January 7, 2002.

26 Guanli xinxi (Management Information), 2002, Issue 3, p. 23.

27 Renmin ribao, January 17, 2001. 


\section{Second transition of the Communist Party of China}

1 This chapter was published in Zhanlue yu guanli (Strategy and Development), No. 3, 2002.

2 Yaobang Hu, Dishierjie dangde daibiao dahui baogao (Report to the Twelfth Party Congress), 1982.

3 National Long-Term Strategy Research Group, Zui yanzhong de jingao: jingji fanrong beihou de shehui buwending (The Most Serious Warning: Social Instability behind Economic Prosperity), China Studies Reports, Beijing: Center for China Studies, 2002, Additional Issue 4.

4 Dengxiaoping wenxuan (Selected Works of Deng Xiaoping), Beijing: Renmin chubanshe (People's Press), vol. III, p. 364.

5 A. Hu et al., "Zhongguo gongchandang ruhe daibiao guangda qunchong de gengben liyi" (How Does the Communist Party of China Represent the Fundamental Interests of the Broadest Possible Masses of the People) in Zhongguo da zhanlue (China's Grand Strategies), Hangzhou: Zhejiang renmin chubanshe (Zhejiang People's Publishing House), 2003.

6 Y. Zhengn, "Zhongguo gongchandang de zhuanxing yu guojia jianshe" (Transition of the CPC and Construction of the Country), China Studies Reports, Beijing: Center for China Studies, 2002, Issue 28. This is one of the reports on the construction of the basic systems of the country.

7 Since 1982, the National Secretary of CCP has made political reports to Party Congresses: (1) Twelfth Party Congress (1982), "Create in an All-Round Manner a New Situation for Socialist Modernization," which stressed the central task of economic construction, setting the goal of quadrupling the industrial and agricultural output value, making great efforts to build a high degree of socialist spiritual civilization and a high degree of socialist democracy so as to build socialism with distinct Chinese characteristics; (2) Thirteenth Party Congress (1987), "Advance along the socialist road with distinct Chinese characteristics," which put forward the thesis about the primary stage of socialism and set the goal of quadrupling GNP, making clear the basic line of "One center, two basic points" so as to build, step by step, a new system of planned commodity economy and also set the long-term and near-term goals for the reform of the political system; (3) Fourteenth Party Congress (1992), "Accelerate the pace of reform, opening up and modernization and seize greater victories in building socialism with Chinese characteristics," which stressed the theory of building socialism with Chinese characteristics and set the goal of reform as building a socialist market economy; (4) Fifteenth Party Congress (1997), "Holding high the great banner of Deng Xiaoping theory and bring the building of socialism with Chinese characteristics into the 21st century," which reaffirmed the theory of the primary stage of socialism and put forward the idea of ruling the country by law.

8 World Bank, World Bank Development Report 1997: The State in a Changing World, New York: Oxford University Press, 1997.

9 X. Wang, Ouzhou lishishang de guojia jiqi jianshe (States in the History of Europe and Their Construction), China Studies Reports, Beijing: Center for China Studies, Issue No. 34, 2002.

10 Y. Zheng, Zhongguo gongchandang de zhuangui; S. Wang, "Money and Independence - Dilemma of a Civil Society," China Studies Reports, Beijing: Center for China Studies, 2002, Issue 31; J. Zhou, Reconstruction of Core Values and Building of Basic State Systems, China Studies Reports, 2002, Issue 30; H. Wang, Shichang yu zhengfu guifan: meiguo jingyan (Market and Government Regulation: Experience of the United States), China Studies Reports, 2002, Issue 32; X. Wang, Reform of Progressive Times in the United States - on the Orientation of Institutional Transition of China, China Studies Reports, Beijing: Center for China Studies, 2002, Issue 34. 
11 A. Hu et al., Zhongguo gongchandang ruhe daibiao guangda qunzhong de genben liyi (How Does the Communist Party Represent the Fundamental Interests of the Broadest Possible Masses of the People), China Studies Reports, Beijing: Center for China Studies, 2000, Issue 63.

$12 \mathrm{Hu}$ et al., Zhongguo gongchandang ruhe daibiao qunzhong de liyi.

13 Zedong Mao, Dangwei de gongzuo fangfa (Work Method of Party Committees), Maozedong xuanji quanjuan (Selected Works of Mao Zedong all-in-one edition), Beijing: Renmin chubanshe (People's Press), 1964, p. 1333.

13 Making policy decision-making more scientific, democratic, systematic and specialized

1 This chapter is the postscript to the new work by the author, Zhongguo: Xin fazhan guan (China: New Conception of Development), Hangzhou: Zhejiang renmin chubanshe (Zhejiang People's Press), January 2004. It was written on December 9, 2003.

2 Guo Qing and Hu Angang, Zhongguo gongyehua wenti chutan (Tentative Exploration into China's Industrialization), Beijing: Zhongguo kexue jishu chubanshe (China Science and Technology Press), 1991, pp. 169-171.

3 Ross Terrill, Maozedong de houbansheng (the Chinese edition of Mao: A Biography (1980)), Beijing: Shijie zhishi chubanshe (World Knowledge Press), 1989.

4 Y. Kwan and G. Chow, "Estimating Economic Effects of Political Movements in China," Journal of Comparative Economics, vol. 23, 1996, pp. 192-208; Cai Fang and Lin Yifu, Zhongguo jingji (China's Economy), Beijing: Zhongguo caizheng jingji chubanshe (China Finance and Economics Press), 2003, p. 9.

5 Bo Yibo, Ruogan zhongda juece yu shijian de huigu (Recollection of Major Policy Decisions and Events), Beijing: Zhonggong zhongyang dangxiao chubanshe (CPC Party School Press), 1993, pp. 1275-1292.

6 At the Lushan Conference in July-August, 1959, Peng Dehuai criticized the serious problems brought about by the Great Leap Forward, pointing out that the tendency of bragging began to grow. The craziness of the petty bourgeoisie made us easy to commit "leftist" errors, he said. In the Great Leap Forward, some "leftist" tendencies prevailed, we were as eager to step into communism in one stride and such ideas prevailed for some time. It is very difficult to set this idea to rights. This has been proven by the historical experience of the Communist Party of China.

7 In 1975, Mao Zedong proposed that Deng Xiaoping hosted the political bureau meeting to give an assessment of the Great Cultural Revolution and take a decision that the revolution was 70 percent successful and 30 percent failure. Deng Xiaoping resolutely refused it. He never yielded on issues of principle. This prompted Mao Zedong to set his foot down to carry out the movement of criticizing Deng Xiaoping and opposing the rightist tendency of reversing the verdict. Starting from late November, Deng Xiaoping was suspended from presiding over central work and put in charge of foreign affairs. In late November, the CPC central committee called a 130-people meeting. The meeting heard the highlights of a speech approved by Mao Zedong, which said: "What happened in Qinghua University is not isolated. It is the results of the struggle between the two classes, two roads and two lines." Mao Zedong could not tolerate Deng Xiaoping who tried to correct systematically the mistakes of the "Great Cultural Revolution" and he launched the movement of criticizing Deng Xiaoping and "Opposing the Rightist Deviationist Tide of Reversing the Verdict," thus plunging the country into turmoil again.

8 Dengxiaoping wenxuan dierjuan (Selected Works of Deng Xiaoping, Volume 2), Beijing: Renmin Chubanshe (People's Press), 1994, p. 293.

9 Renmin ribao (People's Daily), August 15, 1986. 


\section{Notes}

$10 \mathrm{Hu}$ Angang, Zhongguo fazhan qianjing (Prospects of China's Development), Hangzhou: Zhejiang Renmin Chubanshe (Zhejiang People's Press), 1999, pp. 89-90.

$11 \mathrm{Hu}$ Angang, Zhou Jianmin, and Wang Shaoguang, "Goujian guojia anquan tixi, qianghua weiji chuli nengli" (Construct National Security System and Intensify Crisis Handling Capabilities), in Zhongguo guoqing fenxi yanjiu baogao (Analysis and Reports of China Studies), No. 37, May 21, 2000. 


\section{Index}

The following abbreviations have been used in this index:

CPC: Communist Party of China

TFP: total factor productivity

adaptation mechanism, for coping with aging society $178-9$

added values 13; industrial 13, 14

administrative corruption 220-1

aging society: challenges of $168-72$;

coping with 177-9; trend of 168-71

agricultural labor force (see also farmers)

116-17, 128, 130; flow to cities 102 ,

$116-17,205$; incomes of 101,102 ;

liberalization 30 ; need for

representation 131; transfer of 92,101 , 102, 126-7, 130, 206

agricultural products 129 ; price of 81 ,

$104,118,129$

agriculture $115,116,20$

AIDS 134, 138, 141; ignorance about

159; measures to control 147

air pollution 28

alcohol consumption 158

'An Analysis Report on the Third

National Health Services Survey' 152 announcement and information systems 250

anti-poverty strategies $107,124,125-32$;

and health improvement 150

arable land 36

arbitrary charges $220-1$

army 232

auditing 244-5

baby boom period $174-5$

backwardness, and catch-up 9-11, 19

Bangladesh 99

banking, market orientation 22

basic living allowance 193-4

Beijing 26, 68; birth rate 76; human poverty index 72 ; unemployment 191 , 102

birth control 146-7

birth rate 168, 176; regional differences 76-7

Bo Yibo 248

Boqiang, B. 64

Botswana 208

Brazil, impoverished population 108

bribery $217-18,244$

Canada, timber exports 213

cancer 138

capital 11, 16, 17-18; production 209; productivity 61 ; tangible 64

capital deepening 201

capital resources 36-7, 42, 50

capital stock growth 16, 17, 18, 60, 61

catch-up 9-11, 19-20, 29

central government 27, 204; anti-poverty policies 104, 107, 110; conflicting interests with local government 91 , 93-4; and economic development 225-6, 228; and educational development 280; health development objectives 148-51, 161-5; mandatory plans 88 ; market reform 22; powers in planned economy 204; reform of 58, 244-5; role in regional development 91, 93; and social development 27, 31; transfer payments $93-4$

child health 157, 163

China Institute of Contemporary International Relations 40

Chinese Academy of Social Sciences 39

Chinese Military Academy 39 
Chow, G. 248

Cipollone, P. 173

class struggle 247

Cline, R. 39

coal industry 64, 210, 216

coastal regions $84,88-9$; human poverty index 72; social development 76

coercive mechanism 232

collective enterprises, laid-off workers 81 , 191

commercial energy usage 48, 49

'common prosperity' 57, 89, 226

common understanding mechanism 232

Communist Party of China 224-5, 228; Central Committee 87-8, 235, 236, 237, 253; constitution of 235,236 ,

237; and economic development 224-5, 227-8; General Secretary 236, 237, 238; leadership 236-8; legitimacy of 228; National Congress 30, 89, 124-5, 134, 147, 148, 228, 230, 235, $236,249,250$; reform of $234-8,249$; relationship with people 234 ; and socialist political democracy 228-31

competitiveness $22,33,57,125$

comprehensive national power $33,34,43$, $46,55,67$; changes in, in great powers 41-4; measuring 38-41; national strategic resources $35-8$

Constitution of People's Republic of China 86, 238, 240, 242, 243, 244 construction industry 200, 202, 206 consumer spending, urban/rural gap 26 coordination mechanism 232-3 continuing education $181-2$ corruption 27, 226, 229, 234; anticorruption measures $243-4,245$; economic costs of $66,217-23$; investigations into 244

crime 27

cultural development indicators 79

Cultural Revolution 175, 247, 248-9

death rate 168

defalcation 217-18

defense spending 58

democracy 229, 234, 249; CPC and 235-6 democratic centralism 249, 250

democratic decision-making 213, 240, $249,250-1$

demonstrations 199

Deng Xiaoping 88, 226, 229, 230; Cultural Revolution and 248-9; and economic development 29-30 desertification of land 28

development gap 12

development history of China 12-13

development strategies 29-30, 88-9, 91,

148; green 31 ; human-oriented $86-7$

dire poverty rate 107

dirty energy 210

Disabled Adjusted Life Years 144

disabled people 159

disaster management 57

disease: economic costs of 144-5, 160-1, 162; incidence of 154-5; smoking and 158; urban/rural gap 138-9

domestic demands 128

drinking water, access to safe 157,158 , $159,163,164$

east/west gaps $84-5$

eastern regions 84 ; knowledge capabilities 77 ; poverty rate 110

ecological environment: cost of protection policies 213-14; need to improve 31 ; pollution 211, 26

economic advisory committee 251

economic consequences of unemployment 196-7

economic costs: of corruption 66, 217-23; of disease 144-5, 160-1, 162

economic development (see also development strategies) 247; beneficial to poor 137; and political reform 229 , 230; regional disparities $70-1,82-3$ economic globalization $11,33,67,91$, 103

economic growth $13,14-15,67,100-1$, 203-4; challenges to 26-9; employment and 28-9, 199-200, 206; factors driving 18-25; in first transition 224-5; and pro-poor growth 65-6; rate of 97, 107; social crises and 226; source of 15-18; TFP and 61-2; theories of 11

economic indicators 78

economic resources, measuring 35,42 economic restructuring, and employment structure 200-2, 207

education $57,95,126,180$; after age 15 $15,16,18,35,60$; compulsory 180-1; and economic growth 35 ; improvement in 103-4; income and 173; investment in for poor 131; for laid-off 188 ; tertiary $18,46,47,61,135,137$; urban/rural gap 180-1 education indicators 78 
electricity production 47,49

embezzlement 219-20

employment (see also labor force growth; unemployment; working-age population): creation of for poor 130 ; economic growth and 28-9, 199-200, 206; economic restructuring and 200-1, 207; in formal/informal economy $201,202,204,205,207$; in rural areas 116

endowment insurance 173

energy depletion costs 210

energy sources 58

environmental degradation 28,226

environmental indicators 76,79

expert consultation 250

exports: and economic growth 19-21, 29; role in poverty reduction $102-3$

expression mechanism 233

extreme poverty rate 107

family planning $146-7,248$

famine 126

farmers 102, 104, 121; delegates to 10th National People's Congress 131; income of 106, 115-16, 120, 130; unemployment of 185,187

fertility rate 168 ; regional disparities 76

financial swindling 221

financial system, reform of 58

fiscal distribution, and urban/rural income inequality $119-22$

fiscal policies 58 ; for poverty reduction 129

Five-Year Plans 210, 253; health objectives 162, 164-5; and unemployment 199, 202

food problem 16

foreign direct investment (FDI) 36, 50, 102; acquisition of new technologies 24

forestry $28,57,213$; depletion costs 212-13

formal economy, employment in 201, 202, 204, 205, 207

Fucks, W. 38

Fujian province 68 ; unemployment in 191

Gansu 68, 192

GDP (gross domestic product) 16, 29, 35, 45-6, 55, 67, 136, 137; aging and 171; comparison of major countries 11-12, 13, 45; of 'four worlds' 68; green 208; per capita growth rate $100-1,107$,

$111,114-15$; prioritizing growth in 87 ; gender equality 126

genuine domestic savings 209, 216, 221; cost in natural resources $209,215-16$

German, C. 38

Gerschenkron, A. 9, 10

Global Competitiveness Report 2000 45, 46

global resources security strategy $215-16$

GNP (gross national product) 35

good governance 225, 227; in health 150

governance, levels of 86

government see central government; local government

government resources 37, 42, 53, 55, 58

Great Cultural Revolution 175, 247, 248-9

Great Leap Forward, losses caused by $247-8$

green development 31

green national accounts system 145, 208, 215

gross national income 68

Guangdong 26, 68; labor force flow into 103; unemployment in 191

Guizhou province 68,72

health $126,146-7$; challenges to $137-45$; expenditure on 148-9; fair distribution of resources 150 ; history of relationship with economic growth 134-7; macro-economy and 133-4, $144-5,149-51$

health development: evaluation of 164-5; indicators of $78,142-3,146$; objectives of 145-7; regional differences 139-41, 142-3

health education 147

health/healthcare services 136-7 145, 156; access to 75,145 ; investment in 148-51; for poor 131-2; regional disparities 139-41

Hebei province 68

Heilongjiang province 68, 191

Henan province, unemployment in 191

Hong Kong 97, 197

horizontal effect 18

hospitals, births in 157, 163

housing, in suburban areas 93

Hu Angang 251-2, 252-3

Hu Jintao 30, 166

$\mathrm{Hu}$ Yaobang 229

Hua Guofeng 229 


\section{Index}

Hubei province, unemployment in 191, 192

human capital (see also human resources) 64; growth of 18, 61, 176; indicators of in early industrialization 135-6; investment in 57, 89, 177-8, 216; relationship to life-long income 173 ; resources 35,42 , 46-7

human development 32, 126; indicators of 79 ; regional differences $71-5,82-3$

Human Development Index 57, 71

human insecurity 165-6

human-oriented development 86-7, 88

human poverty 110,112

Human Poverty Index 72, 112

human resources $35,42,46-7$; and aging society $168,177-9$; development of 95, 179-83; and gross national wealth 208-9

Hunan province: birth rate 76 ; unemployment 191, 192

ideational ethos 34

illegal capital transfers 220, 223

illiteracy $110,113,180$

illness insurance 192, 193

immunization programs 157,163

imports of technologies 23-4

impoverished population (see also rural population, impoverishment of) regional distribution 109-10, 120

income distribution 91 ; inequality in 26-7, 29, 30, 64-5, 118-24, 226; regional differences $81,84,86$

income poverty 110,112

incomplete information 250-1

India 43; capital resources 51; China as threat to 44; economic resources 45 , 46, 47; government resources 53; human capital resources 47, 48; impoverished population 99, 108; international resources 56; knowledge and technological resources 50, 52; military power 54 ; natural resources 49

Indonesia 99; impoverished population 108

industrialization (see also modernization) 67 ; and aging society 167 ; China as latecomer 11-15

industry (see also manufacturing industry) 14, 88; monopolies 91

infant health 157,163

infant mortality 104, 135, 137, 146, 149, 163; urban/rural gap 157 informal economy 205-6; employment in 201, 202, 204, 205, 207

infrastructure indicators 76,79

insecurity $165-6,197-9$

institution building 225-8, 231-3; objectives of 231 ; and socialist political democracy 229-31

institutional changes, and economic growth 16,17

institutional effect 21-2

integration mechanism 233

interest groups 27, 91, 234

international aid, to develop health care $150-1$

international resources $38,43,55,59$

Internet hosts 37,50

investment $18,57,61,62-3$; to aid poor 130; domestic 36, 50, 208; foreign direct 36, 50, 103; hardware/software 27,31

Japan 43; capital resources 51; catch-up with USA 10, 19; China as threat to 44; economic resources $45,46,47$; forestry 213; human capital resources 48 ; government resources 53 ; increase in per capita income 100; international resources 56; knowledge and technological resources 50, 52; military power 54; natural resources 49

Jiang Zemin 30, 89

Jiangsu 26, 68; birth rate 76 ; unemployment 191

Jilin 68,80 ; birth rate 76 ; unemployment 191,192

judicial system, reform of 245-6

Kennedy, P. 44

Knorr, K. 38

knowledge accumulation indicators 16 , 17,24

knowledge and technological resources $37,42,50,51,53,58$

knowledge development: 16, 17; implementation of strategy 95-6; indicators of 17, 77, 80; innovation 58; regional disparities $77-81,82-3,86$

knowledge poverty 110,112

Korea: Republic of, catch-up with Western Europe 10; South, increase in income 101

Kwan, Y. 248

labor disputes 27, 197 
labor force 35-6; growth of 16, 17, 31-2, 61

labor market 57-8, 92, 203

laid-off workers 175, 177, 184, 185, 187; age structure 188, 190; continuing education for 181-2; education structure 188; pensions for 175 ; receiving basic living allowances 193-4; re-employment 205, 207; regional characteristics 191-2; sectoral characteristics 190, 191; sources of 190

land use reform 92, 93

latecomers to industrialization, benefits for 10-11, 19

leadership 230, 231, 249; of CPC 236-8; retirement age for state leaders 253

Li Shimin, Emperor 225

Liaoning province 68 ; birth rate 76 ; unemployment 191, 192

liberalization 21-2, 29

life expectancy 104, 135, 137, 138, 144, 149 ; and aging society 182 ; after retirement 172; urban/rural gap 157

life-long education 57, 179-83

living standards 125,162

loans, for poor 19

local government 27; and health development 150; responsibilities in regional development 92; unable to fund some social services 93-4

Ma Yinchin 248

Macao 197

macroeconomic policies, for poverty reduction $128-9$

Maddison, A. 11, 12, 45, 135, 136

malnutrition 110

manufactured goods, exports of 21

manufacturing industry $13,200,202,206$; laid-off workers 190, 201

Mao Zedong 248; Four Modernizations 29

market economy 21-2, 29, 201, 225

market-oriented reform $21-3$

marketization 67, 200, 203

markets, opening up, and regional development 91-2

medical insurance $155-6,165,262 \mathrm{n}$

mental resources of labor 179

military power, and economic growth 37 , $42,54,53-5,58-9$

Millennium Development Goals 125, 126, 166

mineral depletion 211-12 mineral industry 200, 202, 206; laid-off workers 190, 201

modernization 9, 11-15, 227; catch-up paradigms 9-11

monetary policies, for poverty reduction 129

monopolies, corruption in 218-19

national accounts system 208; green 145 , 208, 215

national conditions $250-1,252$

National Health Services Surveys 152, 166

National People's Congress 236, 238; 9th Five-Year Plan 164; reform of 238-44; selection system of delegates 131 ; standing committee 240, 242, 243

national power 34

national security 57,88

national strategic resources 34-8, 42

natural capital 64, 209; costs of 208, 209, 210-16

natural resources $28,47-50,64,95$; depletion costs 209-10, 211-13; and economic growth $36,42,209$; exploitation of 209; genuine domestic savings 209, 215

New China, baby boom period 173, 174 non-nationalization 200

occupational injury insurance 192, 193

old age insurance 173

old age support ratio 170,171

old age support system 168; human capital and 173-7

old people (see also aging society) education and training for 182-3

'one China, four worlds' 26, 67, 80, 134

'one China, two systems' $26,80,81,134$, 260

open economy 200

opening-up effect 19-20, 225

Orsen, M. 19

'Outlined Children's Development Program for the 1990s' 162, 163

'Outlined Program for China's Women's Development (1995-2000)' 162, 163, 164

Pakistan 99

participation in democracy 231 ; by poor people 131

patent applications 37,50

peasants see agricultural labor force 


\section{Index}

Peng Dehuai 248

pensions, for laid-off workers 175

'people first' 32, 66, 252, 253

people's deputies 239, 241, 242-3, 244; need for equal distribution 240, 242; discrimination against rural population 238,240

per capita income growth 57,136 per capita income level 57, 68-9, 100-1, 114-15, 119

personality cult 237

physical resources of labor 178-9

planned economy 201, 203-4, 225

police 232

policy decision-making 247,249 ; collective 249; democratic and scientific 231, 249, 250-1; personal 248, 249; think-tanks 247, 252; through consultation 249-50

political consequences of unemployment 197-9

political power, of CPC $227-8$

political reform 229, 233-4, 250-1; of CPC 234-8; economy and 230; goals of 230-1; of government 244-5; of judicial system 245-6; of National People's Congress 238-44

pollution 28, 209, 216; costs of 209, 211

poor see impoverished population; poverty

poor-aid $129-30$

population (see also working-age population) 28,57 ; of 'four worlds' 68 ; growth of $57,247,248$; indicators of 76-7, 78; movement of 92, 101-2;

Porter, M. 35

poverty (see also impoverished population) $32,57,72,91$; characteristics of $110-11$

poverty line 106-7, 108-9

poverty reduction $65,97-100$; economic growth and 100,106, 111, 114-18; new strategies for 124-32; reasons for 100-5; since 1990s 106-7, $111-24$

power industry 218

PPP (purchasing power parity) 35, 223

pre-natal examinations 157

pregnant women, mortality of 146

primary products, exports of 21

private enterprises 201, 205, 206, 207

pro-poor growth 65

production, market orientation 22

production capital 209 productivity (see also total factor productivity) 26, 61

'Proposals on Formulating Ten-Year Program for Social Development, and the "Eighth Five-Year Plan"” 162

protest rallies 199

public expenditure: embezzlement 219-20; on health 148-9

public finance, reform of 58

public investment, corruption in 220

public services $27,31,93,129$; access to 93-4; urban/rural gap 26, 119-20

quality of life 87, 93, 162

Qinghai, laid-off workers 192

redistribution mechanism 233

re-employment opportunities 207

regional development 68 ; coordination of policies 87-9, 90; evolutionary trend of disparities 85-6; implementation of knowledge development strategy 95-6; uneven 69-81, 89

regional development gaps 26-7, 29, 30; policies to reduce $129-30$

regulatory mechanism 232

representation in National People's Congress 131, 238-40, 241-2

research and development, spending on $24,37,50,52$

reserve mechanisms, for coping with aging society $177-8$

retirement age $171-2,182$; for state leaders 253

rural areas (see also urban/rural gaps): 106; need for investment in infrastructure 30; opportunities for employment 116, 130; public health services 157; water improvement projects 164

rural education programs 131

rural population (see also agricultural labor force), impoverishment of 72, 97, 101, 106, 109, 128

Russia 43; capital resources 51; economic resources 45, 46, 47; government resources 53; human capital resources 48 ; international resources 56 ; knowledge and technological resources 50,52 ; military power 54 ; natural resources 49; timber exports 213

Sachs, J.D. 133, 209

sanitation 126 
SARS 89, 252

savings (see also genuine domestic savings) 11,145

scientific and technical indicators 76,78 scientific and technological cooperation 24

scientific theses 37,50

Sen, A. 97

'seven provisions' 128

Shaanxi 68, 80; laid-off workers 192

Shandong 68; birth rate 76 ; unemployment 191

Shanghai 26, 68; birth rate 76

Shenzhen 26, 68

Singapore 97

smoking 157-8

smuggling 218

social consequences of unemployment 197

social consultation 249,250

social costs 27,6

social development 27,31 ; beneficial to poor 137 ; indicators of $75-6$; regional disparities $75-7,82-3,86$

social justice 226

social security 165,173 ; in period of economic transformation 205; in planned economy 203; pressure on 171-2, 175, 177; reform of 92; urban unemployment and 192-5, 207

social stability $197-8$; and economic prosperity $225,226,229$

socialism 229

socialist political democracy 228-31, 249, 250

soft power 34,59

south/north gap 84-5

Soviet Union (see also Russia), catchingup with USA 9, 10, 19

speed effect 18-19

standard of living 32

State Auditing Office 130, 244-5

State Council 238, 251

state-owned enterprises 88,201 ; corruption in 219; laid-off workers 64, $81,84,190,192,206$; privatization of 220

state sector $225-6$

State Security Commission 251

state systems 231-3; modernization of $227,231,234-46$

strategic resources, changing 44-55

structure effect 19

sustainable development $31,57,58$
Taiwan 197; catch-up with Western Europe 10

Tan Zhenlin 248

tariff barriers 216

taxation 119, 122, 124, 129, 243; evasion of 218,219

technological innovation 58; and catch-up $11,22-3$; leading to unemployment 201

technology (see also knowledge and technological resources): 17; sources of 23-4

telecoms industry 218

Tellis, A. 34, 39

Terrill, R. 247

Tianjin 26, 68; unemployment 191

Tibet 68, 75

timber output 212-13

toilets, targets for raising availability and use 162,163

total factor productivity (TFP) $16,18,60$; drop in 61-3 (reasons for 63-6)

trade $19-21,55,57,129,150$

training 57, 180, 181

transfer payments system $30,93-4,129$, 243

unemployment (see also laid-off workers) $66,107,184-5,226$; among baby boom generation 175 ; characteristics of urban unemployed population 188-92; consequences of 195-9; definitions of 185-6; destruction of traditional jobs 201, 202, 206; estimate of 186-8; structural 206

unemployment insurance 192-5, 207; coverage 192; funds financed by government 194-5

unitary state 8

United Nations, Millennium Declaration on population and health 146

United Nations Development Program, 'China Human Development Report 2002' 75

United States of America 43, 100; capital resources 50, 51; catch-up with UK 9, 10, 19; challenge to, from China 44; economic resources $45,46,47$; government resources 53; human capital resources 47,48 ; international resources 56 ; military power 54 ; natural resources 49 ; timber exports 213

uptake capability mechanism 232 


\section{Index}

urban population, impoverishment of 72 , 107,109

urban/rural gap 26, 29, 30, 118-21, 134; disease 138-9; education 180-1; infant mortality 157; life expectancy 157 urbanization $30,92-3,101-2$

values, core 232

vocational education 57,181

Waltz, K. 34

Wan Li 249

water 48, 49, 126, 128; households without safe drinking water 157,159 ; pollution of 28

'well-off society' 30, 57, 125, 148, 252

Wen Jiabao 124, 154, 252, 253; and coordination 87; development gaps 29, 30

'Western Development' strategy 30, 89

western regions 72 ; impoverished population 72,74 ; knowledge capability 77,80 ; poverty rate $109-10$ women, deaths of, in pregnancy 163

working-age population $28-9,35,46,64$; age structure 172 ; proportion of 168 , $170,171,172$

World Bank 46, 65, 81, 145; green national accounts $145,208-10,215$; 'Growth Quality' 63-4; poor population $98-9$; poverty reduction 124

World Health Organization 153

World Trade Organization, accession to 92, 130, 207

Wu Bangguo 251-2

Wu Guanzheng 252

Yunnan province 191

zero tariffs 216

Zhao Ziyang 229

Zhejiang 26, 68; birth rate 76; labor force flow into 103

Zhou Eulai 248

Zhu Rongji 251-2

Zou Ping 252-3 
eBooks - at www.eBookstore.tandf.co.uk

\section{A library at your fingertips!}

eBooks are electronic versions of printed books. You can store them on your PC/laptop or browse them online.

They have advantages for anyone needing rapid access to a wide variety of published, copyright information.

eBooks can help your research by enabling you to bookmark chapters, annotate text and use instant searches to find specific words or phrases. Several eBook files would fit on even a small laptop or PDA.

NEW: Save money by eSubscribing: cheap, online access to any eBook for as long as you need it.

\section{Annual subscription packages}

We now offer special low-cost bulk subscriptions to packages of eBooks in certain subject areas. These are available to libraries or to individuals.

For more information please contact webmaster.ebooks@tandf.co.uk

We're continually developing the eBook concept, so keep up to date by visiting the website.

\section{www.eBookstore.tandf.co.uk}










